\title{
Samenwerking en academisering huisartsgeneeskunde; van pragmatisme tot modelontwikkeling : theoretische en praktische bijdragen aan het proces van samenwerking tussen huisartsen en universiteiten
}

Citation for published version (APA):

Kocken, R. J. J. (1995). Samenwerking en academisering huisartsgeneeskunde; van pragmatisme tot modelontwikkeling : theoretische en praktische bijdragen aan het proces van samenwerking tussen huisartsen en universiteiten. [Doctoral Thesis, Maastricht University]. Rijksuniversiteit Limburg. https://doi.org/10.26481/dis.19950615rk

Document status and date:

Published: 01/01/1995

DOI:

10.26481/dis.19950615rk

Document Version:

Publisher's PDF, also known as Version of record

Please check the document version of this publication:

- A submitted manuscript is the version of the article upon submission and before peer-review. There can be important differences between the submitted version and the official published version of record. People interested in the research are advised to contact the author for the final version of the publication, or visit the DOI to the publisher's website.

- The final author version and the galley proof are versions of the publication after peer review.

- The final published version features the final layout of the paper including the volume, issue and page numbers.

Link to publication

\footnotetext{
General rights rights.

- You may freely distribute the URL identifying the publication in the public portal. please follow below link for the End User Agreement:

www.umlib.nl/taverne-license

Take down policy

If you believe that this document breaches copyright please contact us at:

repository@maastrichtuniversity.nl

providing details and we will investigate your claim.
}

Copyright and moral rights for the publications made accessible in the public portal are retained by the authors and/or other copyright owners and it is a condition of accessing publications that users recognise and abide by the legal requirements associated with these

- Users may download and print one copy of any publication from the public portal for the purpose of private study or research.

- You may not further distribute the material or use it for any profit-making activity or commercial gain

If the publication is distributed under the terms of Article $25 \mathrm{fa}$ of the Dutch Copyright Act, indicated by the "Taverne" license above,

Download date: 26 Apr. 2023 


\title{
Samenwerking en Academisering Huisartsgeneeskunde;
} van pragmatisme tot modelontwikkeling

\author{
Theoretische en praktische bijdragen aan \\ het proces van samenwerking \\ tussen huisartsen en universiteiten
}

\author{
PROEFSCHRIFT \\ Ter verkrijging van de graad van doctor \\ aan de Rijksuniversiteit Limburg te Maastricht, \\ op gezag van de Rector Magnificus, Prof.Mr. M.J.Cohen \\ volgens het besluit van het College van Dekanen, \\ in het openbaar te verdedigen op donderdag 15 juni 1995 om 14.00 uur. \\ door \\ Reinier Johannes Jacobus Kocken \\ geboren te Sittard \\ op 2 november 1957
}




\section{Promotores:}

Prof.Dr. J.A. Knotmerus

Prof.Dr. H.F.J.M. Crebolder

\section{Beoordelingscommissie:}

Prof.Dr. F. Sturmans (voorzitter)

Prof.Dr. T.L.C.M. Groot (Vrije Universiteit Amsterdam/Open Liniversiteit - Heerlen) Prof.Dr. H. Maarse

Prof.Dr. H. Philipsen

Prof.Dr. E. Schadé (Universiteit van Amsterdam) 


\section{Samenwerking en Academisering Huisartsgeneeskunde; \\ van pragmatisme tot modelontwikkeling}

Theoretische en praktische bijdragen aan het proces van samenwerking tussen huisartsen en universiteiten 
(Delen van) deze studie werd(en) financieel en inhoudelik mogelijk gemaakt door bijdragen van

\section{- Ministerie van WVS}

- Begeleidingscommissie Academisering Eerstelijns Gezondheidszorg (BAEG)

- Projectgroep Evaluatie Stimuleringsregeling Universitaire Huisartspraktijken

- Mediselect bv

Publisher of the European Journal of General Practice - Amersfoort

\section{Paranimfen:}

Ellen Breevoort - Zeguers

Paula Smeets - Rinkens

Kocken R.J.J.

Samenwerking en Academisering Huisartsgeneeskunde;

van pragmatisme tot modelontwikkeling.

Theoretische en praktische bijdragen aan het proces van samenwerking tussen huisartsen en universiteiten / Reinier Johannes Jacobus Kocken.

ISBN $90-9008317-0$

Grafische vormgeving en Printing:

Unigraphic Maastricht 


\section{INHOUDSOPGAVE}

Hoofdstuk 1

Inleiding

1.1 Huisartsgeneeskunde in historisch perspectief

1.2 De begrippen samenwerking en academisering in de huisartsgeneeskunde

\section{Hoofdstuk 2}

Literatuur over academisering huisartsgeneeskunde

$2.1 \quad$ Inleiding

$\begin{array}{lll}2.2 & \text { Literatuur national } & 18\end{array}$

$\begin{array}{ll}2.3 & \text { Literatuur internationaal } \\ 26\end{array}$

2.4 Samenvatting en conclusies $\quad 31$

2.5 Literatuur $\quad 32$

\section{Hoofdstuk 3}

Case-study: Een huisartsgeneeskundig academiseringsnetwerk

\subsection{Inleiding}

3.2 Voorgeschiedenis

3.3 Begripsbepaling

3.4 Werving, contractering en omvang $\quad \mathbf{4 2}$

$3.4 .1 \quad$ Contractering $\mathbb{1}^{\text {e }}$ fase 43

3.4.2 Contractering $2^{e}$ fase 43

3.4.3 Contractering $3^{\mathrm{e}}$ fase 44

3.4 .4 Contractering $4^{\mathrm{e}}$ fase 45

3.4.5 Contractering $5^{\mathrm{e}}$ fase 45

3.4 .6 Omvang 45

$\begin{array}{lll}3.5 & \text { Financiering } & \mathbf{4 7}\end{array}$

3.5 .1 Inleiding 47

3.5.2 Financiële middelen 47

3.5.3 Financiële vertaling naar de geacademiseerde
huisartspraktijken

3.5.3.1 Prestatie tegen salaris $\quad 51$

3.5.3.2 Prestatie tegen prestatie $\quad 52$

3.5.3.3 Prestatie tegen geld 53

3.5.3.4 Outputfinanciering 53

3.5.3.5 Exploitatiekosten $\quad 54$

3.5.4 Totale vaste jaarlijkse kosten 54 
3.6 Contracten en werkplannen

3.6.1 Inleiding 55

3.6.2 Contractvormen academisering huisartsgeneeskunde 55

3.6 .3 Werkplannen 56

3.7 Aansturing van processen in het HAM 56

3.8 Evaluatie $\quad 60$

3.9 Literaturur $\quad 60$

Hoofdstuk 4

Modelbeschrijwing affiliatie

4.1 Inlleiding 65

4.2 Werving van affiliatie-praktijken voor onderwijs
en onderzoek; een gefaseerd model

$\begin{array}{lll}4.3 & \text { Evaluatie } & 70\end{array}$

$\begin{array}{lll}4.4 & \text { Literatuur } & 72\end{array}$

Hoofdstuk 5

Modelbeschrijving academisering: theoretische onderbouwing. $\quad 73$

$\begin{array}{lll}5.1 & \text { Inleiding } & 73\end{array}$

5.2 Positionering van de partijen $\quad 74$

5.2.1 De huisartspraktijk als eenvoudige structuur $\quad 74$

5.2.2 De universiteit als professionele bureaucratie 75

$\begin{array}{lll}5.3 & \text { Organisatie en netwerk } & 76\end{array}$

5.4 Netwerken; soorten, strategie en "spel" 77

5.5 Netwerken; paradox en onrust $\quad 78$

5.6 Coördinatie en beheersing van de taakuitoefening 79

5.6.1 Transactiekostentheorie 80

$\begin{array}{lll}5.6 .2 & \text { Agency-theorie } & 82\end{array}$

5.7 Nadere analyse van de praktijk van het academiseringsnetwerk in relatie tot relevante theorieèn. 83

5.8 Samenvatting en conclusie 90

$\begin{array}{lll}5.9 & \text { Literatuur } & 92\end{array}$

Hoofdstuk 6

Academisering van de huisartsgeneeskunde;

Onderzoek naar de ontwikkeling van huisartsgeneeskundige

academiseringsnerwerken in Nederland; wat is her doel, de definitie en de kwantitatieve en kwalitatieve omschrijwing van zo'n netwerk? 


\section{Hoofdstuk 7}

Onderzoek naar inhoud, proces en uitkomst van de academisering van de huisartsgeneeskunde van

de Rijksuniversiteit Limburg

Hoofdstuk 8

Het oordeel van huisartsen over deelname aan

wetenschappelijk onderzoek

Hoofdstuk 9

Planning en coördinatie van onderwijs en onderzoek

in huisartspraktijken; volgt de huisarts bij participatie

aan universitaire projecten de opgegeven voorkeursgebieden?

Hoofdstuk 10

Onderzoek naar management-aspecten in een

vakgroep huisartsgeneeskunde

Hoofdstuk 11

Algemene beschouwing en aanbevelingen

11.1 Inleiding

11.2 Epicrise

11.3 Methodologische beperkingen

11.4 Aanbevelingen

156

11.5 Vervolgonderzoek

Literatuur

Samenvatting

Summary

Curriculum vitae

Dankwoord

Bijlagen

Appendix A

Overzicht huisartspraktijken wan het HAM

Appendix $\mathrm{B}$

Overzicht contractvormen 


\section{HOOFDSTUK 1}

\section{INLEIDING.}

\subsection{Huisartsgeneeskunde in kort historisch perspectief}

Teneindle het onderwerp "academisch", zoals dat in dit proefschrift geanalyseerd wordt, in historisch perspectief te plaatsen, wordt de geschiedenis kort beschreven.

In 1818 leidde een verandering in de geneeskundige staatsregeling tot een scheiding binnen de medische stand. De academisch geschoolde artsen voerden hun taken in de steden uit, terwijl de niet-academisch geschoolden voomamelijk als algemeen arts op het platteland werkzaam waren. Door de verschillende opleidingen bleven er grote kwaliteitsverschillen bestaan, hetgeen onder andere geleid heeft tot de oprichting van de Nederlandse Maatschappij tot bevordering van de Geneeskunst (NMG) in 1849. De roep van de NMG om opleidingseisen en regels te verbinden aan de bevoegdheden van de artsen werd lange tijd niet gehoord. In 1865 werd de wetgeving echter zodanig veranderd dat de bevoegdheid van arts gekoppeld werd aan een universitaire opleiding of staatsexamen. De term arts werd officieel geïntroduceerd en verdrong eerdere begrippen als "geneesheer" en "heelmeester". Met de nieuwe wetgeving wer den ook specialismen een feit. Het aantal "geregistreerde" specialisten groeide in de periode tot 1920 tot ruim 700 . Wan officiële registratie kon pas vanaf 1931 sprake zijn, aangezien op dat moment het Specialisten Register werd ingesteld, met een verdeling in veertien specialismen. Uit dit alles moge blijken dat het beroep van de "algemeen arts" inmiddels onder grote druk was komen te staan.

Een ommekeer kwam tot stand in 1941 toen het ziekenfondsbesluit bepaaide clat ziekenfondspatiënten alleen nog via de algemene arts verwezen konden worden naar een specialist. In 1946 werd de Landelijke Huisartsen Vereniging (LHV) opgericht onder de paraplu van de (inmiddels Koninklijke) Nederlandse Maatschappij tot be vordering van de Geneeskunst (KNMG). In het zelfde jar werd binnen de NMG een beroepsvereniging voor specialisten opgericht.

Niettemin dreigde de huisarts in de viftiger jaren ondergeschikt te worden an het steeds breder wordende veld van specialisten en social-geneeskundigen.

De beroepsgroep der huisartsen reageerde daarop en in 1956 werd het Neder ands Huisarts Genootschap (NHG) opgericht, met als belangrijkste doel de bevordering van de wetenschappelijke uitoefening van de huisartsgeneeskunde. Nog geen jaar Jater (1957) werd begonnen met het uitgeven wan een eigen wetenschappelijk tijdschrift, Huisarts en Wetenschap.

De rol van de huisartsgeneeskunde aan de universiteiten bleef echter beperkt tot incidentele activiteiten in de worm van gastcolleges en dergelijke. In 1964 werd het Nederlands Huisartsen Instituut (NHI) opgericht met als belangrijkste doelstelling de verzorging van onderwijs ten behoeve van huisartsen en het doen van typisch huisartsgeneeskundig onderzoek in de huisartspraktijk. Dit instituut functioneerde los van de universiteit. Het zou tot 1967 duren alvorens de eerste hoogleraar in de huisartsgeneeskunde werd benoemd. Pas in 1977 hebben alle Nederlandse universiteiten een 
hoogleraar huisartsgeneeskunde (eerder waren er op veel plaatsen al wel lectoren). In de tussentijd werd bij Koninklijk Besluit het Academisch Statuut dusdanig gewijzigd, dat ma 1973 een specifieke opleiding tot huisarts word ingesteld en op grond wan het behalen wan het artsexamen de titel van huisarts niet meer mag worden gevoerd. Toezicht op deze opleiding tot huisarts geschiedde door her inmiddels opgerichte College voor Huisartsgeneeskunde (CHG). Eveneens in 1973 werd de Huisartsen Registratiecommissie (HRC) een feit. Eerst in 1.988 werd, mede onder invoed van Europese wetgeving, de duur van de huisartsopleiding op twee jaar gesteld. Recentelijk is besloten dat de huisartsopleiding drie jaar zal gaan duren.

Het was in de jaren tachtig, ondanks deze ontwikkelingen, nog steeds niet vanzelfsprekend dat de huisartsgeneeskunde een (belangrijke) plats in zou nemen op de universitaire landkaart. Een voorbeeld hiervan is de bija-opheffing van de vakgroep huisartsgeneeskunde van cle Rijksuniversiteit Leiden in 1986, onder druk van facultaire bezuinigingen. In zijn algemeenheid kan voorts geconstateerd worden dat de primaire financiele kaders voor de vakgroepen huisartsgeneeskunde in Nederland in de afgelopen jaren niet verbeterd zijn en dat de afhankelijkheid van externe geldbronnen sterk is toegenomen.

In 1984 werd vanuit het Ministerie van Onderwijs en Wetenschappen het extramuraal gerichte (gezondheidszorg)onderzoek aan twee universiteiten, de Vrije Universiteit te Amsterdam en de Rijksumiversiteit Limburg, middels extra financiële middelen gefacillteerd. Deze middelen zijn aan de Rijksuniversiteit Limburg gedeeltelijk aangewend voor huisartsgeneeskundige projecten en voor de ontwikkeling van de academisering wan de huisartsgeneeskunde.

De vaststelling van het Basistakenpakket van de Huisarts, cle oprichting van de Verenigingen ter ondersteuning wan Huisartsen ( $\mathrm{VOH}$ ), de Stichting Deskundigheidsbevordering Huisartsen (SDH) en de introductie van het Standaardenbeleid van het NHG completeren deze historische schets wat betreft de professionele ontwikkeling van de huisartsgeneeskunde.

De academisch-wetenschappelijke ontwikkeling bereikte een milpaal door de erkenning die de huisartsgeneeskunde en haar wetenschappelijke grondslag kregen in het rapport van de commussie gezondheids(zorg)wetenschappen van de Koninklijke Nederlandse Academie van Wetenschappen $(1991)^{3}$

Voor een uitgebreide historische beschriving kan verwezen worden naar Blanken ${ }^{1}$, wiens uiteenzeting gebruikt is voor deze historische schets. Ook het leerboek huisartsgeneeskunde wan van $\mathrm{Ds}^{2}$ werd voor deze historische beschrijving gebuikt.

Deze schets geeft inzicht in het proces dat nodig was om vanuit de huisartsgeneeskunde erkenning te krijgen als professie en als academische discipline (vakgroepen met aigen leerstoelen). In feite omvatte dit de eerste vorm van academisering van de huisartsgeneeskunde. Dezk eerste vorm wordt verder niet besproken.

De tweede vorm van academisering stat centraal in dit proefschrift: het creèren van een stevige basis voor universitair huisartsgeneeskundig onderwijs en onderzoek, en voot de ontwikkeling van academische eerstelijnsgeneeskunde, in het professionele huisartsenveld. Deze tweede vorm wordt in dit proefschrift verder kortweg als "academisering" aangeduid.

De historische ontwikkeling van deze academiseringsvorm in de huisartsgeneeskunde word belicht in de de hoofdstukken 2 en 5 (literatur en theoretische onderbouwing). 


\subsection{De begrippen academisering en affiliatie}

De meeste mensen zullen ervan op de hoogte zijn dat een academisch ziekenhuis zijn status ontleent aan de aanwezigheid van een universiteit in de directe nabijheid.

In de volksmond wordt het begrip "academisch ziekenhuis" ook vaak in verband gebracht met de mogelijk hogere kwaliteit van het betreffende ziekenhuis of met de mogelijkheid om met zeer specifieke en ernstige ziektebeelden juist bij een dergelijk ziekenhuis aan te kloppen.

Het begrip acadenisch wordt in het algemeen niet in relatie gebracht tot de eerstelijns gezondheidszorg. Eigenlijk is dat vreemd, aangezien zowel de intramurale (de ziekenhuizen) als de extramurale (huisartsen en andere eerstelijns werkers) patientenzorg behoefte hebben aan een relatie met de universiteit en aan patiëntenzorg op "academisch" niveau.

Academiseren zou kunnen betekenen "het op academisch niveau brengen van een alideling of werkgebied", hetgeen geschiedt door het betreffende werkgebied in de vorm van een separate afdeling in een academie of hogeschool onder te brengen. De meest eenvoudige definitie zou dan ook kunnen zijn dat een afdeling geacademiseerd is, zodra op het betreffende terrein een hoogleraar benoemd is. $W_{i j}$ noemen dit de eerste vorm van "academisering". Bezwaar tegen deze definitie is, dat de relatie tussen dle universitaire afdeling en het praktizerende veld er niet in tot uiting komt.

Zowel in de academische ziekenhuizen als in de huisartsgeneeskunde ontstonden de impulsen tot academisering vanuit de patiëntenzorg en vanuit de universiteiten.

Bij de academische ziekenhuizen lag het inhoudelijke accent van de academisering van het praktizerende veld vanaf het begin mede op de patiëntenzorg, met name vanwege de behoefte aan top-klinische zorg. De huisartsgeneeskunde daarentegen streeft bij academisering in eerste aanleg niet naar top-klinische zorg. Erkenning en verbetering van de huisartsopleiding, integratie van de huisartsgeneeskunde in de opleiding tor basisarts en het realiseren van mogelijkheden voor huisartsgeneeskundig wetenschappelijk onderzoek waren en zijn tot op heden de belangrijke argumenten om academiseringsconcepten in de huisartsgeneeskunde uit te werken.

De beinvloeding van de patiëntenzorg vanuit de academisering was dan ook doorgaans een indirecte, namelijk via de participatie aan wetenschappelijk onderzoek en onderwijs. Voorts brengt het generalisme van de huisartsgeneeskunde met zich mee dat een "academische" beoefening van de patiëntenzorg niet eenvoudig te conceptualiseren is. In het latste decennium is een dergelijk concept echter binnen handbereik, met name door de inspanningen vanuit de beroepsgroep zelf. Genoemd kunnen worden het tot bloei komen van het huisartsgeneeskundig wetenschappelijk onderzoek, het standaardenbeleid van het Nederlands Huisartsen Genootschap (NHG), de ontwikkelingen op her gebied van de automatisering in de huisartsgeneeskunde en de ontwikkelingen op het gebied van de thuiszorg en de transmurale zorg. Het generieke karakter van de academische huisartsgeneeskunde is inmiddels ook erkend door de Koninklijke Nederlandse Academie van Wetenschappen (KNAW)3. Door deze ontwikkeling is er een sterke behoefte ontstaan om de "academische" en de "praktizerende" tak van de discipline bij elkaar te brengen ten voordele van beide partijen.

Een tweede verschil tussen de ontwikkeling van de academisering in de ziekenhuizen 
en in de huisartsgeneeskunde betreft de relatie tussen de vakgroep en het "praktizerende veld ${ }^{\text {i }}$. De ziekenhussafdeling en de corresponderende universitaire vakgroep kunnen niet beschouwd worden als twee volledig onafhankelike partijen die tot nadere samenwerking moten komen, hetgeen in de relatie tussen een universitaire vakgroep huisartsgeneeskunde en het met har communicerende huisartsgeneeskundige veld wel het geval is. Meestal was de ziekenhuis-afdeling reeds aanwezig en werd daaraan, gefaciliteerd door overheidsfinanciering (de Rijkbijdrage), een universitaire vakgroep gekoppeld. De klinische afdeling en dus de patièntenpopulatie kwamen daarmee, uiteraard tegen allerlei voorwaarden, vrij direct beschikbaar voor universitair onderwijs en onderzoek.

In de huisartsgeneeskunde is de situatie anders. Twee qua primaire doelstellingen en werkplek verschillende partijen, de vakgroep en de elders gevestigde, zelfstandige huisarts moeten elkaar proberen te vinden en dit proces moet voor beide partijen (zakelijk, inhoudelijk en emotioneel) aantrekkelijk worden gemaakt. Bovendien moet een dergelike academische relatie worden ontwikkeld met een groot antal, individuele en sterk verschillende huisartspraktiken (netwerkworming). Het bij elkaar brengen van deze twee partijen is zeer complex, te meer daar er nauwelijks structurele financiële impulsen gegeven zijn, noch vanuit het eigen beroepsveld, noch vanuit de overheid.

Dat het academiseringsproces huisartsgeneeskunde juist in Nederland grote aandacht heeft gekregen is niet zo vreemd. Het niveau van de Nederlandse huisartsgeneeskunde is hoog en de structuur van onze gezondheidszorg biedt goede mogelikheden om een academiseringsconcept huisartsgeneeskunde uit te werken. De centrale rol van de huisarts en het "listing" en "refertal" systeem zijn sterk faciliterend voor de integratie van de dagelijkse patientenzorg en het onderwijs en onderzoek op het gebied van de huisartsgeneeskunde in een academisch herkenbaar en welomschreven concept.

Voor de volledige uitvoering van het universitair onderwijs en wetenschappelijk onderzoek zullen de academische netwerken nooit voldoende omvang hebben.

Er blijft dan ook behoefte bestaan aan andere samenwerkingsvormen tussen de universiteit enerzijds en het praktizerende veld. Deze doorgaans minder omvangrijke en minder continue vorm van samenwerking wondt affiliatie genoemd. Affiliatie wijkt op het eerste gezicht niet erg af van academisering aangezien ook bij affliatie de nadruk ligt op de integratie van onderwijs, onderzoek en patiëntenzorg. De gemaakte afspraken gelden echter doorgaans voor één of slechts enkele onderwijs- óf onderzoekprojecten, terwijl de duur van de samenwerking in principe een eindig karakter heelt.

Dit proefschrift beschrijft, analyseert en evalueert het proces van samenwerking met en academisering van het huisartsgeneeskundig veld en hoopt ook bijdragen te leveren aan de verdere ontwikkeling van inzichten in en bekendheid met het onderwerp "acadenisering huisartsgeneeskunde!". 
De volgende vraagstellingen zijn nader bestudeerd:

1

Wat zijn definitie, doel en belangrijkste kenmerken van de academisering van het huisatsgeneeskundig veld?

2

Kan aan de hand van de huisartsgeneeskundige en de bedrifseconomische literamur een theoretisch kader gevonden worden voor de academiseringsprocessen in de huisartsgeneeskunde?

\section{3}

Kan aan de hand van dit theoretische kader en op basis van de concrete ervaringen een model worden ontwikkeld, zowel voor de academisering wan de huisartsgeneeskunde als voor de samenwerking tussen universiteiten en huisartsen op "affiliatie-basis"?

4

Welke ontwikkeling heeft het academiseringsnetwerk huisartsgeneeskunde van de Rijksuniversiteit Limburg (het Huisartsgeneeskundig Academiseringsnetwerk Maastricht $=$ HAM) doorgemaakt (case-study)?

5

Welke zijn de verbanden tussen het gevonden theoretisch kader en de praktische uit werking van het HAM?

6

Wat zijn de ervaringen wan participanten aan huisartsgeneeskundige academiseringsnetwerken, zowel lokaal als nationaal?

7

Hoe wordt het management binnen een vakgroep huisartsgeneeskunde ervaren (case study)?

8

Welke variabelen spelen een belangrijke rol bij het afwegingsproces van individuele huisartsen om al dan niet aan een samenwerkingsproject met de universiteit (op het gebied van wetenschappelijk onderzoek) deel te nemen?

9

Zijn planning en coördinatie van onderwijs en onderzoek in de huisartsgeneeskunde te verbeteren aan de hand van door de huisarts opgegeven specifieke voorkeursgebieden? 
Deze vraagstellingen volgend leidt dic tot de volgende hoofdstukken.

Hoofdstuk 1 geeft een algemene inleiding, warin de huisartsgeneeskunde in historisch perspectief wordt geplaatst en de begrippen samenwerking en academisering nader worden toegelicht.

Hoofdstuk 2 beschriff de lokale, nationale en internationale literatuur op het gebied wan de samenwerking en academisering van de huisartsgeneeskunde.

Hoofdstuk 3 geeft een gedetalleerd inzicht in het Huisartsgeneeskundig Academiseringsnetwerk Maastricht (HAM), waatbij wordt stilgestaan bij het daadwerkelijke wervings- en contracteringsproces, de mogelijke contractvormen, de werkplannen en de financieringsmodellen.

Hoofdstu 4 beschriff vanuit de modelmatige invalshoek de zogenaamde affiliatiesamenwerking tussen huisartsen en universiteiten, waarbij de werving van geinteresseerde huisartspraktijken centraal staat.

Hoofdstuk 5 biedt, voornamelijk wanuit de organisatiekundige invalshoek, een theorerisch kader aan, van waruit het academiseringsproces in de huisartsgeneeskunde verklaard kan worden. Ook de relatie tussen de aangeboden modellen en theorieèn enerzijds en de praktische invulling van het HAM anderzijds wordt besproken.

In de hoofdstukken 6 tot en met 10 worden de resultaten van empirisch onderzoek naar specifieke deelaspecten van de samenwerking tussen huisartsen en universiteiten beschreven.

Hoofdstuk 6 beschrijf de belangrijkste uitkomsten van een onderzoek naar de ervaringen van participanten van huisartsgeneeskundige academiseringsnerwerken in Nederland, terwill boofdstuk 7 aandacht besteedt aan inhoud, proces en uitkomst van de academisering van de huisartsgeneeskunde van de Rijksuniversiteit Limburg.

Hoofdsuk 8 geeft een beeld van het oordeel van huisartsen over deelname aan huisartsgeneeskundig wetenschappelijk onderzoek, uitgaande van de universiteit.

Hoofdstuk 9 beschriff de planning en coördinatie van onderwijs en onderzoek in (geacademiseerde) huisartspraktijken, waarin met name wordt stilgestaan bij de vraag of huisartsen bij de daadwerkelijke participatie aan universitaire projecten de eender opgegeven voorkeursgebieden volgen.

Ondat voor een goede samenwerking tussen twee partijen het management van groot belang is, is een onderzoek gedaan natr diverse management-aspecten van de vakgroep huisartsgeneeskunde (boofdstuk 10).

Hoofdstuk 11 tenslotte bevat een algemene beschouwing en anbevelingen.

De bijlagen geven een gedetablleerd overzicht van de contractvormen, het werkplan, de in het retwerk participerende huisartsen alsmede van het zogenaamde Coordinatie-
bureau Eerste Lijn.

De relatie tussen vragstelling en hoofdstukindeling is in schema 1.1 aangegeven. 


\section{Schema 1.1. Relatie tussen vtaagstellingen en hoofdstukindeling.}

\section{Vraagstelling Omschrijiving van de vraagstelling}

II

2

\subsection{Literatuur}

1

Blanken AJ, Oudkerk RH. Samen werkt het beter; een onderzoek natar de samenwerking tussen universikeil en huisartsen. Groningen: Faculteit Bedrijlskunde, Rijksuniversiteit Groningen, 1988

2.

Es JC wan, Patient en huisarts; Een leerboek huisartsgeneeskunde. Ooshoek, Scheltema \& Holkema. Utrecht, 1980

3.

Rapport van de subcommissie gezondheids(zorg)wetenschappen, Koninklifke Nederlandsc Academie van wetenschappen, 1991

\section{Hoofdstukiken}




\section{HOOFDSTUK 2}

\section{LITERATUUR.}

\subsection{Inleiding}

Ter onderbouwing van de modelbeschrijvingen op het gebied van academisering en affiliatie werd de literatuur bestudeerd. Vanuit een huisartsgeneeskundige en bedrijfseconomische invalshoek werd een literatuursearch gedaan. De literatuursearch werd zowel lokaal, nationaal als internationaal gericht, waarbij de volgende trefwoorden of combinaties van trefwoorden werden gebruikt:

\section{nederlandstalig}

- samenwerking

- netwerk(en)

- academisering, academie, academisch

- affiliatie

- huisartsgeneeskunde

- gezondheidszorg

- management

\section{engelstalig}

- cooperation

- network(ing)

- academy

- affiliation

- general practice, family medicin

- (primary) health care (system)

- management

Eveneens werd bekeken of de genoemde trefwoorden in (een gedeelte van) de titel voorkwamen.

De search werd in eerste instantie verricht via Medline.

Toen het resultaat daarvan teleurstellend bleek, werd besloten een beperkt aantal indices meer gedetailleerd te bestuderen:

- de catalogi van de acht Nederlandse universiteiten met een valkgroep huisartsgeneeskunde;

- de jaargangen $1990 \mathrm{t} / \mathrm{m} 1993$ van de nationale tijdschriften:

Huisarts en Wetenschap

Medisch Contact

Nederlands Tijdschrift voor Geneeskunde

- de jaargangen $1990 \mathrm{t} / \mathrm{m} 1993$ van de internationale tijdschriften:

British Journal of General Practice

Canadian Family Physician

Family Practice

Scandinavian Journal of Primary Health Care

Via de gevonden literatuur werden eventuele referenties nader onderzocht.

Het bleek dat er slechts weinig wetenschappelijke literatuur verschenen is expliciet gericht op de samenwerking tussen universiteiten en huisartsen ten behoeve van onderwijs en onderzoek. Het trefwoord "academisering" (en de engelstalige varianten 
daarvan) is in geen van de catalogi bekend. De nationale literatuur biedt op diverse punten nietuemin belangrijke aanknopingspunten voor de beschrijving van samenwerkings- en academiseringsconcepten. De gevonden internationale literatuur houdt zich met name bezig met de optimalisering van de samenwerking tussen huisartsen en universiteiten (of zelfstandige research-centres) op het gebied van wetenschappelijk onderzoek. Slechts een beperkt aantal artikelen beschrijt de ervaringen van zogenaamde University Teaching Practices, die qua concept vergelijkbaar zijn met de huisartsgeneeskundige academisering in Nederland.

In dit hoofdstuk wordt de relevante literatuur beschreven. In 2.2 wordi de nationale literatuur besproken, terwijl 2.3 relevante internationale publikaties behandelt.

\subsection{Nationale ontwikkelingen}

Van Weel ${ }^{1}$ wijst in zijn inaugurale rede op het belang van de samenwerking met het huisartsgeneeskundige veld. "De relatie met het veld van patiëntenzorg is essentieel. Dit geldt voor de intramurale klinische afdelingen, dit geldt evenzeer voor de universitaire huisartsinstituten. Fraaie voornemens op het gebied van onderzoek en onderwijs gaan er impliciet vanuit dat dit in de praktijken van participerende huisartsen te realiseren is. In de naaste toekomst - uitbreiding van co-assistentschappen, verlenging van de beroepsopleiding, uitbreiding van het patiëntgebonden onderzoek, automatisering en academisering - zal de band tussen het huisartsinstituut en huisartspraktijken nog intensiever worden."

Ook tijdens de oraties van Crebolder en Knottnerus wordt nadrukkelijk stilgestaan bij het belang van samenwerking en academisering op huisartsgeneeskundig terrein.

Crebolder ${ }^{2}$ gaat in op het belang van samenwerking tussen de regionale eerstelijns werkers en de universiteit. Als belangrijkste probleem in de bestaande situatie wordt genoemd het ontbreken van het institutionele karakter (dat een laboratorium en de kliniek wel hebben) dat nodig is ten einde de noodzakelijke randvoorwaarden te kunnen realiseren. "Noch over de hulpverleners, of zij nu onderwijs geven of onderzoek verrichten, noch over de patiënten kan zomaar worden beschikt. Het is goed te beseffen, dat elke medewerking vanuit het veld geschiedt op basis van individualiteit, vrijwilligheid en wederkerigheid. Voor beide partijen, veld en universiteit, moet de verhouding aantrekkelijk en voordelig zijn. Eén van de modellen om de relatie tussen faculteit en eerstelijns veld vorm te geven is de zogenaamde academisering." 2 .

Ook Knottnerus ${ }^{3}$ onderschrifft het belang van samenwerking tussen universiteit en eerstelijn. "Een conditio sine qua non voor - zowel uitvoerbaar als relevant - huisarts" geneeskundig onderzoek is een goede relatie met de huisartsen in de regio. Van groot belang hierbij is een gelijkwaardige relatie tussen de partners, met erkenning van elkaars rol en bekwaamheden."

De gedachtenvorming over de fenomenen samenwerking en academisering in de huisartsgeneeskunde was onderwerp van het symposium "Faculteit en eerste lijn", gehouden aan de Rijksuniversiteir Limburg op 21 en 22 november 19804 . Tijdens dit symposium werd ingegaan op het belang van de academisering van de huisartsgeneeskunde vanuit diverse invalshoeken. Aan de orde kwam het belang van academi- 
sering voor de realisatie van volksgezondheids-doelstellingen, voor de specialistische zorg, voor de relatie met de geestelijhe gezondheidszorg alsmede voor de relatie wan de eerstelijn met de samenleving en bevolking.

Twee bijdragen van her symposium zijn van bijzonder belang. Allereerst de bijdrage van Van Es, zoals in 1981 gepubliceend in Medisch Contact 5 . Hil gaat in op het specifieke karakter van de eerste lijn en het daaraan gekoppelde belang voor geneeskundige faculteiten dit specifieke karakter nadrukkelijk tot witing te laten komen in de opleiding (zowel in het basiscurriculum als de beroepsopleiding tot huisarts). Besproken worden de voorwaarden, wadraan het extramurale veld zou moeten voldoen, de problemen, die verwacht kunnen worden, de verantwoordelijkheidsverdeling en de beschikbare gelden.

Geconcludeerd wordt dat "èn door de dxar aangeboden problematiek èn door het gehanteerde probleemoplossende proces èn door de specifieke vraagstelling de ziekenhuisgeneeskunde en de eerstelijns geneeskunde een groot aantal essentièle verschillen vertonen", en clat "een medische faculteit deze aspecten (op het gebied van onderwijs en onderzoek, die van het extramurale veld verwacht kunnen worden niet buiten haar gezichtsveld kan blijven houden; het gaat on zodanig centrale vragen clat dit in feite onmogelijk is."

Tijdens hetzelfde symposium spitst Browwer 4 het belang van een goede relatie tussen faculteit en eerste lijn toe op de situatie van de geneeskundige faculteit van de Rijksuniversiteit Limburg. In de bijdrage "Wat moet er in Maastricht nog gebeuren?" wordt het creèren van een eerstelins arbeidsveld voor onderwijs en onderzoek eén van de belangrijkste actiepunten van de Maastrichtse universiteit genoend. "Wat het laboratorium is voor de vakgroep fysiologie, wat de kliniek is voor de afdeling chirurgie, dat is de huisartsgeneeskundige praktijk voor een afdeling huisartsgeneeskunde. Elke medische faculteit die ten behoeve van onderwijs en onderzoek wil samenwerken met personen en instellingen in de extramurale gezondheidszorg, zal in die extramurale sector moeten investeren teneinde dat veld onderwijs- en onderzoekrijp te maken."

Mede als reactie op de belangrijkste bevindingen wh het symposium schreven De Groot en Knotmerus in 1982 een artikel met als titel "Academisering van de eerste lijn of vermaatschappeliking van de academie? Het dilemma van professionalisering en democratisering" 6. De wrag word gesteld of de doelen van de beide partijen wel met elkaar in overeenstemming te brengen zijn en welke gevaren er op de loer liggen. "Men kan zich voorstellen dat ex een superprofessioneel bouwwerk ontstaat dat zich relatief autonoom gaat ontwikkelen ten opzichte van de concrete hulpbehoefte en de directe invloed van de gebruikers van de zorg. De eerste lijn wordt dan een proeftuintje in plaats van een zelfstandige inspiratiebron." Geconcludeerd wordt dat er geen nieuwe zorglaag zou mogen ontstaan, terwijl het tevens onjuist zou zijn cle academise ringsplannen te concentreren op gezondheidscentra. "Veeleer zou het zo moeten zijn dat in de relatie tussen faculteit en eerste lijn de diversiteit in samenwerkingswomen tot zijn recht komt." Central in het betoog van De Groot en Knotnerus staat de richtingbepaling van het proces. Niet de academie zelf, maar juist het veld zou die riching moeten aamgeven. Vervolgen kunnen in overleg tussen faculteit en eerste lijn de relaties omschreven en daar waar mogelijk geconcretiseerd en gerealiseerd worden.

Als reactie hierop schrijft Brouwer 10 in zijn artikel "Academisering in de eerste lijn een noodzaak" dat het goed mogelijk is plannen met betrekking tot de acaclemisering in 
de eerste lijn te ontwikkelen in harmonie met de belangen van het veld.

Het ligt in de lijn der verwachtingen dat na de opname van de huisantsgeneeskunde als discipline in alle geneeskundige faculteiten en de ontwikkelingen in het kader van de beroepsopleiding tot huisarts, de oprichting van een academisch onderwijs- en onderzoeksveld de volgende stap in de professionalisering van de huisartsgeneeskunde zou moeten zijn.

In het artikel "Academische werkplaats eerstelijns-gezondheidszorg" beschrijft Mulder? in 1982 een profiel van een zogenaamde academische werkplaats in de eerstelijns gezondheidszorg (AWEG). AWEG's worden gedefinieerd als geaffilieerde groepspraktijken of gezondheidscentra, die op gestructureerde wijze bij het onderwijs zijn betrokken, waarbij het accent ligt op onderwijsvernieuwing. Tegelijkertijd wordt echter bij de te stellen eisen opgenomen dat patiënten van een AWEG gevraagd mag worden mee te werken aan onderwijs en onderzoek, zodat de link naar het onderzoek ook in dit artikel gelegd wordt. Interessant is dat Mulder een vrij uitgebreid profiel van een academische werkplaats probeert te ontwikkelen.

In dit profiel onderscheidt hij 3 categorieën van eisen:

- Eisen ten aanzien van de praktijksituatie (accommodatie, registratie, samenwerking en uitoefening patiëntenzorg)

- Eisen op het gebied van onderwijs, onderzoek en nascholing

- Eisen in de relatie tussen de AWEG en de universiteit (contract e.d.)

In hetzelfde jaar beschrijven De Melker en Pool een model van een zogenaamd Academisch geneeskundig centrum ${ }^{8}$. Dit centrum wijkt qua gedachtengang af van de eerder genoemde academische werkplaatsen. Een academisch geneeskundig centrum zou moeten bestaan uit 4, op specifieke terreinen werkzame, onderdelen, te weten het academische ziekenhuis, de academische huisartspraktijken, de algemene onderwijsziekenhuizen en verpleeginrichtingen en onderwijshuisartspraktijken. Deze onderdelen zouden op elk taakgebied, patiëntenzorg, onderwijs/onderzoek en opleidingen, met elkaar moeten samenwerken en op het gebied van onderwijs en onderzoek met de faculteit der geneeskunde en eventuele andere faculteiten.

Daar waar het academisch ziekenhuis top-klinische zorg zou moeten verlenen, daar levert de academische huisartspraktijk huisartsgeneeskundige zorg op academisch niveau. Voor de implementatie van dit model wordt door De Melker een stapsgewijze
oplsouw voorgesteld.

In het artikel "Wat wringt er in de eerstelijns gezondheidszorg?" 9 wordt de noodzaak van academische centra, met aandacht voor de extramurale gezondheidszorg nogmaals door de Melker onder de aandacht gebracht. De academisering van de extramurale zorg zou een concrete versterking van de eerste lijn kunnen betekenen. "Toekomstige medici zullen immers op een andere gezondheidszorg moeten worden voorbereid. Dat is alleen denkbaar, indien ook de extramurale gezondheidszorg over zorg inhoud kunnen geven."

In 1984 verschijnen twee, op het gebied van academisering, relevante publikaties. Het interfacultair overleg huisartsgeneeskunde (IOH), een structureel overleg van de hoogleraren huisartsgeneeskunde (voorzitters universitaire vakgroepen) beschrijft in 
een uitgebreid rapport "Op weg nar de $A W E G$ " 11 de belangrijkste uitgangspunten, voorwaarden en eisen bij de ontwikkeling van de academisering huisarsgeneeskunde. De verschillen tussen affiliatie en academisering worden bespotken en de academiseringsvorm "acquisitie" wordt geintroduceerd. Affliatie en acquisitie worden omschreven als vormen van academisering, watrbij sprake is wan respectievelijk samenwerking op contractbasis en samenwerking van beide partners (veld en universiteit) met gemeenschappelijke verantwoordelikheid woor het totale beheer (patientenzorg en academische taken). Uit de inventarisatie van het $\mathrm{OH}$ blijkt dat in de periode 1982-1984 bij geen van de universitaire instituten grote stappen in de tichting van de ontwikkeling van een academisch veld zijn gezet. Nog steeds zit men in de fase van theoretische en strategische planning, en slechts op sommige platisen zijn de eerste experimenten geconcretiseerd en geimplementeerd. Volgens het $\mathrm{IOH}$ bestaat er landelijk in ieder geval geen verwarring meer over het begrip "academisering".

"Academiseren is het - uitgaande van de behoefte van de universiteiten aan mogelijkheden voor het ontwikkelen van de huisartsgeneeskunde - voor het geven van praktisch onderwijs en voor het vertichten van onderzoek openstellen van het (regionale) gezondheidszorgsysteem ten behoeve van de ontwikkeling van het onderwijs en het onderzoek in de huisartsgeneeskunde en de regionale gezondheidszorg, wambij wederzijdse participatie van universiteit en zorgveld een vereiste is. "1.1

Het begrip AWEG wordt gedefinieerd als "het geheel van gezondheidsvoorzieningen die geschikt zijn voor het uitvoeren van academische taken naast praktische patientenzorg". Onder dit verzamelbegrip vallen de begrippen "academische praktijk", of "academisch eerstelijns gezondheidscentrum" en "affiliatiepraktijk respectievelijk affiliatiecentrum". Het $\mathrm{OOH}$ beschrijft een model, bestaande uit diverse contractvormen, de voorwaarden en eisen, verschillende organisatievormen en voegt een billage toe met de veelbelovende titel "De B.V. als rechtsvorm voor academische praktijken"."11

Een tweede rapport dat vermelding verdient is "Academisering/Affiliatie; de samenwerking tussen huisartsen en universiteit" 12 van Dijksterhuis. Hierin worden, vanuit de vakgroep huisartsgeneeskunde van Groningen, de academiseringsprocessen bekeken op lokaal, nationaal en international niveau.

Dijksterhuis komt tot enkele, wat hij zelf noemt "eigenwijze" indrukken en aanbevelingen, warvan de volgende genoemd worden:

"Huisartsen zullen liever willen samenwerken met een thiversitair institut met een duidelijk gezicbi, warwan men weet wat men kan verwachten op bet gebled wan onderwijs en onderzoek. Een duidelijke visie of een beleid is dus noodzakelifk. Tetens is een voomaande dat bet niet alleen bij intenteverklaringen blijt, mair dat er ook wat uikomt."

"In plaats wan academisering zouden we bever kunnen spreken wan de samenwerking wissen de vakgroep buisartsgeneeskunde en buisantsen."

"Het is wan belang dat er een persoon is (of enkele personen) binnen de vakgrop die zich inzet(ten) voor de werbetering van de samenwerking met bu isartsen. Maar tevens dien de academisering/affliate wel door de bete vakgroep als werantwoordelijkbeid te worden gevoeld."

"Alle buisartsmedewerkers van de vakgroep dienen ook praktiscb als buisarts in een vaste praktijk te werken woor ten minste vier balve dagen per week." 
Naar aanleiding van het rapport van Dijksterhuis is het zinvol een sprong in de geschedenis maken, omdat het Groningse concept van de universitaire huisarts praktijk mede is ingegeven door ervaringen bij de Edinburgh University General Practice Teaching Unit.

De eerste ervaringen met de universitaire huisartspraktijk te Groningen zijn respectievelijk in $1961^{13}$ en $1970^{14}$ in Huisarts en Wetenschap beschreven.

Opvallend in het concept var de University Teaching Unit in Edinburgh is de constatering dat, ondanks de aanwezigheid van zeer veel studenten in de praktijksetting, de arts-patiêt relatie goed was gebleven en de patiènten nooil bezwar maakten medewerking te vertenen aan de opleiding van de student. Bovendien valt op dat op een patiètenpopulatie van 5.000 patiènten, vier huisartsen, twee maatschappelijk werksters, twee verpleegsters en twee secretaresses werkzaam zijn. Op deze manier ontstaat er met name voor de huisartsen ruimschoots de gelegenheid tijd en andacht te besteden aan onderwijs en onderzoek.

De universitaire groepspraktijk le Groningen is in navolging van de Teaching Unit in Edinburgh opgebouwd. In 1970 worden in het artikel "Éen jaar universitaire groepsprakrijk te Groningen" de belangrijkste conclusies beschreven 16f.

Er wordt met name gezocht naar het antwoord op de vraag "Waarom een universitaire huisartspraktijk?".

Samengevat luidt het antwoord:

- ondat een wetenschappelijk medewerker, die niet dagelijks contact heeft met de huisartspraktijk in al zijn diwerse facetten, kan verschralen tot iemand met een formele, theoretische en academische zienswijze ten opzichte wan het vak van huisarts;

- omdat bij het onderwijs in de huisartsgeneeskunde het best gebruik gemaakt kan worden van "levende" situaties en de casuistiek het beste kan worden toegelicht door de praktizerende huisarts zelf;

- omdar in een universitaire praktijk optimale mogelijkheden aanwezig zijn om research-mogelijkheden te signaleren en in nawwe samenwerking met de vakgroep wit te werken en uit te voenen;

- omdat in een dergelijke praktijk maximale aandacht bestaat voor de ontwikkeling van dagindelingen, waatbij de patiéntenzorg enerzijds en de wetenschappelijke taken anderzijds een duidelijke plaats krijgen.

De evaluatie geet in het algemeen een positief beeld. De huisartsen zijn volledig als ambtenaar aangesteld, zodat elk financieel moment bij de behandeling van patiènten ontbreekt. Dit wordt positief gevonden, alhoewell de "dubbelrol" van actief huisarts en wetenschappelijk medewerker aanpassingsproblemen oplevert. Problemen in de patiëntenzorg interfereren vak met het geconcentreend bezig zijn met de wetenschappelijke takk, terwijl aan de andere kant het gevaar bestaat dat de contacten met de patiènten een te grote theoretische gerichtheid krijgen. Tenslotte bleek - na systematische nawrag - dat patienten geen klachten hadden over de frequente afwezigheid van
"hun" huisarts. 
Na de rume belangstelling woor "academisering" in de begin 80 mer jaren, mede ingege ven door het congres "Faculteit en eerste Lijn", lijkt het er op, dat dit onderwerp in de volgende periode aan actualiteitswaande verliest. Het duurt tot 1987 alvorens Blanken en Van der Meulen de samenwerking tussen universiteit en eerstelijn wamuit een bedriffkundige optiek beschrijven ${ }^{15}$. Zij komen tot enige ideaalrypische vormen van zogenaamde reguleringsmechanismen, op basis waarvan de samenwerking ussen universiteit en huisarts kan worden ingericht. Uitgangspunt is de agency-theorie, een theorie waarbij organisaties (ook interorganisationele samenwerkingsverbanden) gezien worden als een netwerk van ruilrelaties.

"Impliciet en expliciet moeten tussen de partijen die bij de ruil zijn betrokken afspraken worden gemaakt over de uit te voeren activiteiten, de spelregels, de beoordelingscriteria, de beloningen, de rechten van de verschillende betrokkenen en de duur van de relatie." De zogenaande regulering van de ruilrelatie kan plaatsvinden door drie "reguleringsmechanismen", te weten prijsmechanisme, hiërarchie-mechanisme en consensusmechanisme.

\section{Prijsmecbanisme}

Dit mechanisme is gebaseerd op het spel van vrag en aanbod en dus op her streven van betrokken partijen naat maximalisatie van het individuele nut en op de mogelijkheid van snelle toe-en uittreding tot de ruilrelatie.

\section{Hienarchie-mecbanisme}

De regulering gaat in dit verbank uit van een gerichtheid van betrokkenen op het maximaliseren van het gezamenlijke belang en van het bestaan van vaste, continue relaties. Controle van de afspraken gebeurt door een "supervisor", bijvoorbeeld door middel van een periodieke visitatie.

\section{Consensusmecbanisme}

Regulering komt tot stand op grond van gedeelde opvattingen over de te leveren prestaties en tegenprestaties. De partijen zijn het volledig eens over de doelen en de wijze warop deze doelen bereikt kunnen worden.

De onderzokers concluderen dä "voor een dadwerkelijke versterking van de eerste lijn ook de samenwerking tussen universiteit en eerste lijn moet worden verbeterd. Tot nu toe is die samenwerking voomamelijk door medici bestudeerd. Aanvullende deskundigheid en nieuwe invalshoeken lijken echter gewenst. Een economisch getinte, bedriffskundige theorie kan een van die invalshoeken zijn.

Een dergelijke benadering reikt nieuwe gezichtspunten aan die kunnen worden gehanteerd bij de analyse en beoordeling van bestaande samenwerkingsverbanden mussen de eerstelign en de universiteiten en bij het opzetten wan nieuwe samenwerkingsverbanden. Zo'n benadering sluit bovendien aan bij de "cultuurverandering" die zich in de gezondheidssector lijkt te voltrekken. ${ }^{15}$

Op 1 januari 1987 stante de eerste fase van de zogenaamde Tijdelijke Stimuleringsregeling van Universitaire Huisartspraktiken (de TSUH). Uitgande van bet gegeven dat het Ministerie van Onderwijs en Wetenschappen (O\&W) de primaire verantwoordelikheid heeft voor de versterking van de academisering huisartsgeneeskunde ten behoeve van onderwijs (in het basiscurriculum) en onderzoek, was het Ministerie van Wetenschap, Volksgezondheid en Cultuur (wVC) bereid middelen ter beschikking te 
stellen voor de tijdelijke stimulering van de ontwikkeling van de huisartsgeneeskunde in relatie tot de opleiding tot huisarts. De gelden $(\mathrm{Fl} .150 .000=$ per jaar per universitaire vakgroep) konden worden besteed aan de volgende activiteiten:

- het bijhouden van wardigheden door huisarts-stafleden van de vakgroep;

- het ontwikkelen en uittesten van onderwijsmethoden en -modellen in de beroepsopleiding;

- het leveren van een directe onderwijsbijdrage aan de beroepsopleiding;

- het ontwikkelen en ten dele uitvoeren van wetenschappelijk onderzoek in de huisartsgeneeskunde, wederom gerelateerd aan de beroepsopleiding.

Voor de uitvoering en de begeleiding van de stimuleringsregeling werd de BAEG (Begeleidingscommissie Academisering Eerstelijns Gezondheidszorg) ${ }^{33}$ ingesteld. Een projectgroep van de BAEG beschreef het academiseringsproces in een viertal rapporten 29-32. Bovendien werd een artikel "Van gastdocent tot UHP- arts - de ontwikkeling van de academisering van de huisartsgeneeskunde -" gepubliceerd ${ }^{16}$ (UHP=Lniversitaire Huisartspraktijk). Naast een beschrijving van het netwerkmodel in termen van infrastructuur, overlegstructuur en meerjarenplan, bevat het artikel de volgende conclusie.

"Het is waarschijnlijk dat het Ministerie van WVC zich in het kader van de stelselwijziging zal terugtrekken als individueel gesprekspartner en dat de academisering geregeld zal moeten worden binnen het overleg tussen beroepsgroep, ziektekostenverzekeraar en datzelfde ministerie. Zonder een uitbreiding van de financiering staan de ontwikkelingen stil. Het academiseringsproces is nog niet afgerond." 16

Spreeuwenberg 35 besteedt eveneens aandacht aan de onduidelijke situatie op het gebied van de financiering van extramurale werkplaatsen. "Als we het noodzakelijk achten dat er buiten het academisch ziekenhuis werkplaatsen zijn waar op academisch niveau activiteiten plaatsvinden op her gebied van onderwijs, onderzoek en ontwikkeling van de extramurale disciplines, dan moet het zwartepieten worden gestaakt. Het lijkt me redelijk een zeker percentage van de premie-inkomsten voor "research and development" van gezondheidszorgvoorzieningen te bestemmen. Een deel hiervan kan worden aangewend voor het creëren en onderhouden van de benodigde infrastructuur."

Ook in het "Rapport van de sub-commissie gezondheids(zorg)wetenschappen"25 van de Koninklijke Nederlandse Academie van Wetenschappen (KNAW) wordt aandacht geschonken aan dit probleem. Deze commissie werd gevraagd de vakgebieden van het gezondheidswetenschappelijk cluster te definiëren en te beschrijven, een standpunt te bepalen over de criteria voor kwaliteitsbeoordeling in deze sector en nadere voorstellen te doen woor profilering en zwaartepuntvorming. Ten aanzien van het vakgebied Huisartsgeneeskunde worden drie knelpunten geformuleerd: 
Het in vergelijking met de klinici zeer terughoudende personele en carriere beleid ten aanzien van de staf van universitaire huisartsgeneeskundige instituten, wardoor het voor ervaren en bekwame huisartsgeneeskundige wetenschappers steeds minder aantrekkelijk wordt een universitaire loopbaan te kiezen. Dit vormt een bedreiging voor de kwaliteit van het onderzoek en onderwijs en de ontwikkeling van geacademiseerde huisartsgeneeskundige zorg;

2.

Onduidelijk is in hoeverre diverse tijdelijhe stimuleringsregelingen op het gebied van onderzoek en cle relatie onderwijs-gezondheidszorg een vervolg kriggen;

3.

Het in tegenstelling tot de situatie in de academische ziekenhuizen, (nog) niet structureel erkend en gefinancierd worden van academische gezondheidszorg en gezondheidszorgontwikkeling in de huisartsgeneeskunde."

Bij een aantal publikaties ligt het accent meer op de wijze waarop het wetenschappelijk onderzoek of facetten daarwan moet worden uitgevoerd26,27,28. Het samenwerkingsaspect tussen onderzoeker (universiteit) en huisarts wordt daarin wel aangestipt, vooral inhouclelijk en soms organisatorisch. De beleids- en beheersmatige ontwikke. ling komt minder aan de orde. De rol van de patientenzorg in geacademiseerde huisartspraktijken is weliswar erkend, maar krijgt in de literatuur weinig aandacht. In 1994 verschijnt een artikel ${ }^{34}$ waarin een onderzoek naar de patiêntenzorg in de academische huisartspraktijken van de Rijksuniversiteit Limburg wordt gepresenteerd. De patiëntenzorg in de academische praktijken wordt, afhankelijk van diverse factoren, op drie niveau's onderscheiden, te weten een basisniveau, "good clinical practice" en "academisch in strikt zin".

Het basisniveau is het minimale niveau. waaraan elke academische praktijk moet voldoen en heeft voornamelijk betrekking op infrastructurele voorzieningen, zoals voldoende atsen, assistentie, prakrijk- en onderwijsruinte, automatisering, praktijklolder, gestructureerd overleg en teambesprekingen).

"Good clinical practice" onderscheidt zilch van het basisniveau doordat er systematische aandacht bestat voor het gebruiken van de NHG-standaarden, monitoring van categorieën patiënten, zelf doen van wele medisch-technische diagnostische en therapeutische ingrepen, thuiszorg, toetsing en nascholing.

Van "academisch in strikte zin" is sprake als de academische praktijk naast "good clinical practice" ook actief betrokken is bij onderwijsvernieuwing en het genereren van onderzoekhypothesen, publiceren en eventueel promoveren en daamaast ook bijaragen levert an de beleidsmatige ontwikkeling van de vakgroep huisartsgeneeskunde.

Uit alle bijdragen en ontwikkelingen blijkt dat er in ons land geen verschil wan mening bestaat over het belang van samenwerking tussen faculteit en eerstelijn, zowel voor de eerstelijns patièntenzorg, als en misschien wel vooral voor het facultaire onderwijs en onderzoek. Toch blijkt anno 1994 dat de ontwikkeling wan academische centra huisartsgeneeskunde achterblifft bij de ontwikkeling en uitbouw van intramurale academische afdelingen. Het ontbreken van een belangrijke financiele impuls, equivalent aan de impuls voor academische ziekenhuizen (de Rijksbijdrage), lijkt een belangrijke 
reden voor het witbliven van voldoende, onvangrijke huisartsgeneeskundige acade miseringsnetwerken in gehed Nederland.

Op enkele platsen, zoals bij de Rijksunversiteit Limburg, zijn niettemin succesvolle initiatieven genomen, hetgeen niet alleen te danken is an de aldaar aanwezige creativiteit of de gecreeerde regionale gezondheidszorgvoorzieningen en samenwerkings: vormen. Belangrijke factor is ook de waardering en blijvende belangstelling van de universitaire gemeenschap en de regio voor het vakgebied huisartsgeneeskunde. Bovendien zijn de, in het kader van het Vernieuwingsfonds Extramurale Zorg. gecreèrde financiële mogelikheden van groot belang gebleken. In hoofdstuk 3 zal dit nader worden toegelicht.

\subsection{Internationale literaturur}

In de internationale literatuur wordt nauwelijks expliciete aandacht besteed aan het proces van de ontwikkeling van (academische) samenwerking tussen individuele huisartspraktijken en universitaire huisartsgeneeskundige instituten of centra. Sommige artikelen ${ }^{17-23}$ besteden aandacht aan samenwerking met huisartsen op het gebied van wetenschappelijk onderzoek, terwijl twee artikelen 14,24 de ervaringen van een University lleaching Practice beschrijven. Literatuur over samenwerkingsconcepten tussen universiteiten en huisartsen op het gebied van onderwijs werd nauwelijks aangetroffen.

Booth ${ }^{17}$ beschrijft in 1987 uitgebreid de historie van het wetenschappelijk huisartsgeneeskundig onderzoek. In het artikel wordt ook aandacht besteed aan de ontwikkeling van de "college research units" en de toenemende concurrentie vanuit de universitaire huisartsgeneeskundige groepen. De "college research units" hebben voortdurend geworsteld met het probleem van onvoldoende (zekerheid voor de) staf. Booth verwacht dat de universiteiten in de toekomst een belangrijke rol zullen gaan vervullen op het gebied van onderzoek.

Herbert 18 geeft uitvoerig aan welke obstakels overwonnen moeten worden om huisartsgeneeskundig onderzoek adequat te kunnen uitvoeren. Genoemd worden:

- $\quad$ ijjid;

- geld;

- de tendens van huisartsen on in alles geinteresseerd te zijn;

- het geloof van huisartsen, dat ze alles zelf moeten doen; de complexiteit van en de onbekendheid met methodologische aspecten; een gebrek aan zelfverzekerdheid en een gevoel nooit genoeg te weten om een
onderzoek te starten.

Om toch onderzoekers an te trekken is het goed een aantal ontwikkelingen te onderkennen. Alereerst zullen er steeds meer huisartsen (met name vrouwen) partime werkzaam zijn in de patiëntenzorg en daardoor de mogelijkheid krijgen in de resterende tijd aandacht te besteden aan wetenschappelijk onderwijs en onderzoek.

voorts zal de aandacht voor de ontwikkeling wan vaardigheden op het gebied van zelftoetsing, onderinge toetsing en onderzoek bij de opleidingen versterkt (moeten) 
worden, hetgeen de mogelijkheden voor huisartsgeneeskundig onderzoek zal doen toenemen.

Ten derde zal meer en meer gebruik gemaakt gaan worden wan "networks of family practice research". De samenwerking tussen "community-based" en "university-based" researchers zal toenemen, waardoor het potentieel aanzienlijk zal toenemen.

Op de vierde plaats zal vanuit de universiteiten toenemende aandacht ontstan voor de opleiding van huisartsgeneeskundig onderzoekers, voor "research fellows" en voor het aantrekken van subsidies om het onderzoek mogelijk te maken.

Tenslotte zullen er meer onderzoeks-fora moeten ontstaan, zowel op lokaal, nationaal als international niveau. Deze fora moeten zowel voor de universitaire onderzoeker als woor de 'community-researcher' toegankelijk zijn.

Gagnon FA et al 19,20 beschriven in een tweetal artikelen het totale proces van de ontwikkeling en witvoering van een wetenschappelijk onderzoeksproject in de huisarts. praktik. Een project valt uiteen in tien fasen:

1

Voorkomen wan problemen voordat ze ontstaan.

In cleze fase moet er zekerheid ontstaan over de beschikbaatheid van voldoende rijd om het project te kunnen witvoeren. Ook de noodzakelijke ondersteuning en samenwerking dient in deze fase reeds zeker gesteld worden.

2

Genereren van een idee.

Verondersteld wordt dat een onderzoeksidee bij de huisarts vaak reeds aanwezig is. Een dergelijk idee moet in deze fase dan ook besproken worden met collega's om het verder te ontwikkelen.

\section{3}

Bestuderen wan de literatuur.

4

Ontwikke en van het idee.

In deze fase is 'brainstotming' net collega"s en experts een veel gebruikte methode.

5

Ontwikkelen van het onderzoeksplan.

6

Verkrijgen van financièle ondersteuning.

7

Verknigen van ethische goedkeuring.

8

Uirvoeren van her onderzoek.

9

Analyseren van de resultaten.

10

Publiceren en presenteren van de resultaten. 
Murphy et al 21 beschriven het belang van een goed onderhandelingsproces om to overeensterming te komen met eerstelins werkers. De wervingsfase is een belangrif ondercleel van het totale onderzoeksproject. Rume aandacht voor dit deel van het proces zal niet alleen leiden tot een hogere response, maar zal tegelijkertijd de kwali teit van de gevonden data in positieve zin beinvloeden. Murphy beschrift verschillen de stappen om toegang tot de eerste lijn te verkrijgen.

\section{1}

Ontdek en benader de zogenaamde "stakeholders". Hieronder worden die personen of groepen verstaan die een bepaalde interesse of een specifiek belang in het onder zoek kunnen hebben. Van hen mag verwacht worden dat zij het onderhavige project kunnen aanprijzen of, indien zij niet serieus genomen worden, belangrijke obstructie kunnen leveren. Grofweg vallen de "stakeholders" uiteen in twee groepen. Allereerst degenen die rechtstreeks betrokken zullen zijn bij het onderzoeksproject (interne "stakeholders"). Voorts zijn er de zogenaamde externe "stakeholders", personen die niet direct bij het project betrokken zijn, maar wier ondersteuning van groot belang kan zilin.

\section{2}

Als de "stakeholders" zijn gevonden, vindt de fase van strategische planning plaats. De stakeholders spelen bij de ontwikkeling van de strategie een belangrijke rol. Het is dan ook van belang ze in een vroeg stadium in te schakelen. Hun ervaring in inhoudelijke en praktische zin moet een cluidelijke invloed hebben in de fase van strategische planning. Ook hun gedachten over de wijze waarop de participanten aan het onderzoek uiteindelijk moeten worden benaderd zijn belangrijk.

3

De volgende fase in thet model van Murphy betreft de zogenaamde identificatie van "gatekeepers". Aangezien het onderzoek in de eerstelijn (en ook het huisartsgeneeskundig onderzoek) vak te maken heeft met netwerken van samenwerkende personen is het van belang via de juiste persoon toegang te zoeken tot het netwerk. In de engelse situatie werd aravankelijk gekozen voor een eerste contact met de practice manager, maar al snel werd duidelijk dat de invloed van betrokken managers op de dokters marginal is. Bovendien ziet de manager het als zijn taak het netwerk te beschemen tegen belasting van dat netwerk door nietwatiẻntenzorgactiviteiten. Zijn attitude ten anzien van wetenschappelijk onderzoek bleek dan ook doorgaans negatief. Vanut die ervaringen werd dan ook gekozen voor een eerste contact met het prakitij-netwerk langs twee kanalen. De manager en de dokters van de praktijk werden tegelijkentijd benaderd in de vorm van een eerste introductie van het project met een verzoek om hun reacties op her projectvoorstel.

4

Alvorens de onderhandeling met de praktijk te beginnen kan het belangrijk zijn een zogenaamde "local champion" te vinden. Vaak moet de onderzoeker onderhandelen met praktijken, waarvan hij de medewerkers persoonlijk niet kent. Zeker in zo'n geval lijkt het belangrijk een local champion te zoeken, een in de betreffende regio algemeen bekende persoon met enig aanzien. De local champion moet uiteraard woorzien 
worden van adequate informatie over het onderhavige projectvoorstel. Vaak is de local champion één van de eerder genoemde stakeholders.

\section{5}

De vijfde en laatste fase betreft de daadwerkelijke onderhandeling tussen de onderzoeker en de praktik (het netwerk), waamee de samenwerking wordt gezocht. In de onderhandelingsfase, waarin de local champion een belangrije rol speelt, wordt het project besproken aan de hand van een korte beschrijwing van het project, met een focus op de praktische consequenties van participatie door de praktik aan het project. Centrale doelstelling van het ovenleg is tweeledig. Allereerst moet voorkomen worden dat de praktijk deelname weigert op basis van of onvoldoende $\mathrm{c} . \mathrm{q}$. inadequate informatie of op basis van irrationele gronden. Op de tweede plaats moeten de zogenaam de premature toezeggingen voorkomen worden. Zeker bij studies met een lange-termijn-samenwerking tussen onderzoeker en praktijk is het van belang een stevige betrokkenheid te realiseren, alworens het project van start gat.

Centrale vraagstellingen in deze fase zijn:

- Heeft u voldoende informatie over het project (ook in zijn praktische uirwerking) om een besluit over participatie te nemen?

- Zijn er nog aspecten in de studie, die de mogelijke participatie bemoeilijken?

Deze hele benadering moet uiteindelijk leiden tot een gevoel van collectiviteit ten aanzien van het project (collective ownership) zowel bij de onderzoeker als bij de pauticipanten.

Silagy et al 22 onderzochten onder 3350 huisartsen in Australlè de mate van interesse bij de huisartsen in huisartsgeneeskundig onderzoek en de factoren die bij cle beslissing om deel te nemen aan een dergelijk onderzoeksproject een belangrijke rol spelen.

Van de 3350 huisartsen respondeerden er uiteindelijk $\mathbb{1 6 0}$ (35\%).

Van de respondenten gaf $33.7 \%$ aan in hoge mate geinteresseerd te zijn in participatie aan wetenschappelijk onderzoek; $27.9 \%$ had geen enkele interesse. Bij de peiling van de interesse bleken de volgende factoren statistisch van geen belang:

- her geslacht van de huisarts;

- de wijze waarop de huisarts salaris onvangt (loondienst of zelfstandig);

- de organisatiegraad van de praktijk (solo, matschap, groepspraktijk of gezondheidscentrum);

- de aanwezigheid van een patientenregistratie (patiënt master file).

Er werden 6 variabelen onderzocht, die volgens de onderzoekers van belang konden zijn in het besluitvormingsproces van de huisarts om wel of niet deel te nemen aan een onderzocksproject. Dit waren:

- de mate waarin patiẻnten hun medewerking aan het project zouden moeten verlenen;

- de tijd die de huisarts in het project zou moeten inzetten;

- de "belloning" voor de huisarts;

- de mogelikheid om advies en steun van ervaren onderzoekers te kunnen krijgen; de mate warin andere praktijkmedewerkers in het project betrokken zouden moeten worden;

- de mogelijkheid om extra computer-assistentie te kunnen verkrijgen. 
Wanneer de mate van interesse in wetenschappelijk onderzoek werd vergeleken met bovengenoemde "beslissingsfactoren" bleek de steun door ervaren onderzoekers en de tijd die de huisarts beschikbaar moet stellen het meeste te wegen in het beslissingsproces van de huisarts om wel of niet deel te nemen aan wetenschappelijk onderzoek.

Borgiel et al onderzochten in Ontario (Canada) onder 120 at random geselecteende huisartsen (family physicians) welke factoren van belang zijn bij het zogenaamde "recruiting process for family physicians as participants in research"23.

Beschreven wordt een wervingsproces waarbij zogenaamde "physician recruiters" worden ingezet, vergelijkbaar met de local champions uit de eerder beschreven studie van Murphy ${ }^{21}$. Het systeem van persoonlijke benadering van potentiële dokters door een recruiter werd als zinvol ervaren, zeker als de recruiter in zijn district goede bekendheid heeft. In de 44 gevallen dat de recruiter een (volgens de arts) vriendschappelijke relatie onderhield met de beoogde deelnemer, leidde dat tot een deelname van $95 \%$.

Bij het ontbreken wan een relatie tussen de recruiter en de mogelijke participant bedroeg de deeiname $79 \%$.

De persoonlijke benadering (deelname $91 \%$ ) verdient de woorkeur boven de telefonische (75\%) en de gecombineerde benadering via telefoon en brief ( $87 \%$ ). Evenals Murphy 21 constateert Borgiel ${ }^{23}$ dat de realisatie van een solide betrokkenheid, mede op basis van een goed (beschreven) informatiepakket, van essentieel belang is.

De twee artikelen over "university teaching practices" geven nauwelijks aanleiding tot uitgebreide bespreking in het kader van dit proefschrift. Niet de samenwerkingsaspecten of her proces van academisering worden behandeld, maar de verhouding tussen een universitaire en een privé huisartspraktijk ten aanzien wan kostenimplicaties, praktijkomvang, opbouw van de patiëntenpopulatie, verwijzingsgedrag en inkomensaspecten. Rudnick et al ${ }^{24}$ concluderen dat de ontwikkeling van een privé praktijk in Hamilton (Canada) tot een onderwijspraktijk van McMaster University in ieder geval leidde tot een aanzienlijke reductie van de praktijkomvang (met 34\%) en een verschuiving van de patiẻntenpopulatie naar de lagere inkomensgroepen. Vaak wordt verondersteld dat een onderwijspraktijk onrealistisch is, angezien een dergelijke praktijk niet vergelijkbaar zou zijn met de privé praktijken. Het tempo van de patièntenzorg zou langzamer zijn en de aangeboden klinische problemen zouden niet overeenkomen. De studie van Rudnick 24 toont aan dat een praktijk wel degelijk kan integreren met een universiteit en tegelijkertijd een hoge mate van vergelijkbaarheid met de privé praktijken kan behouden. In Hamilton werd een opmerkelijke overeenkomst van klachtenaanbod gevonden voordat en nadat de praktijk een universitaire opleidingspraktijk was geworden.

De internationale literatuur is hiermee beschreven en biedt hoofdzakelijk aanknopingspunten voor de beschrijwing van algemene samenwerkingsaspecten op het gebied van onderwij.s en wetenschappelijk onderzoek. In hoofdstuk 4 (Modelbeschrijving voor de benadering van en de samenwerking met affiliatie-praktijken) wordt hierop nader ingegaan. 


\subsection{Samenvatting en conclusies}

$\mathrm{Er}$ is relatief weinig literatuur beschikbaar is over samenwerkings- en academiseringsconcepten op het gebied van onderwijs en onderzoek in de huisartsgeneeskunde. Nationaal wordt in een aantal inauguraties aandacht besteed aan de noodzaak tot participatie van individuele huisartsen aan universitaire onderwijs- en onderzoekprojecten. Samenwerking met het veld van de patièntenzorg op basis van gelijkwaardigheid en wederkerigheid wordt onontbeerlijk gevonden. Het symposium "Faculteit en Eerste $\mathbb{L i j n}^{\prime \prime}$ in 1980 geeft een belangrijke conceptuele en praktische aanzet tot de constructie van academische werkplaatsen. Het concept van de AWEG (Academische Werkplaats Eerstelijns Gezondheidszorg) wordt vervolgens in de jaren 80-85 verder uitgewerkt.

Pas in 1987 wordt het academiseringsproces ook vanuit de bedrijfskundige invalshoek bestudeerd en beschreven. Hierna volgt een periode waarin, gefaciliteerd door het Ministerie van Welzijn, Volksgezondheid en Cultuur (WVC) de (projectgroep van de) Begeleidingsconmissie Academisering Eerstelijnsgezondheidszorg (BAEG)29-33 belangrijke bijdragen levert aan de verdere ontwikkeling van de idee-vorming over academisering in de huisartsgeneeskunde.

In de internationale literatuur worden suggesties gedaan op her gebied van de affiliatie-samenwerking, met name voor de uitvoering van wetenschappelijk onderzoek in de huisartsgeneeskunde. Slechts in zeer beperkte mate worden initiatieven beschrewen, vergelijkbaar met wat in Nederland "academisering" of "academische werkplaatsen" genoemd kan worden.

De beschreven literatuur is verwerkt in de modelbeschrijvingen, die gepresenteerd worden in de hoofdstukken 4 en 5 . De nationale literatuur is hoofdzakelijk van belang voor het "model academisering", dat in hoofdstuk 5 nader wordt beschreven. In dit hoofdstuk wordt bovendien de organisatiekundige literatuur gerelateerd aan de academiseringsprocessen. Deze literatuur is namelijk van belang voor de theoretische onderbouwing van met name het model academisering.

De internationale literatuur levert vooral ingredienten woor het "model werving affiliathe-praktijken". Dit model wordt in hoofdlstuk 4 besproken. 


\subsection{Literatuur}

1

Weel wan C. Alledagase ziekten en en gezond versand. Inagurate rede Nimegen Katholieke Lniversien Nithegen, 1986

2

Crebolder HFM. Te leer in de eerste lim; inaugurale rede; Mastricht:

Faculteit der Geneeshunde, Riksuniversteit Limburg, 1987

3

Knotherus JA. Diallectek van her onderzock in de huisarthgeneeskunde; inaugurale rede, Maastrich: Faculteit der Geneskunde, Rijksuniversiteit Limburg, 1988

4

Brouwer W, Romme MAJ. Faculteit en eerste-din. Uuedh: Bohn, Scheltema \& Holkema, 1981

5

Es. IC van. Fadulteit en eerste lin, woonstel over de wijze warop de medische faculteit kan worden betrokken bil de extrammatle gewondheidstorg. Med Contact, 1981; 7: 179-82

6

Groot A de, Knotherus $J$ A. Academistring wan de eerste lijn of wamatschappelijking van de academie? Med Contact, $1982 ; 2 ; 37-9$

7

Mulder JD. Academische werkplatis eerstelijns gezondheidszorg. Med Contact, 1982; 26: 761-3 8

Melker RA de, Pool J. Academisch geneeskundig centrum. Med Contact, 1982; 9: 245-9

9

Melker RA cle. Wat wringt er in de cerstelijns gezondhetdszorg: Mwd Contact, 1982; 25:731-4

10

Brouwer W. Achemisering in de eerste lijn cen noodzak. Med Contact, 1982; 11:321-2

11

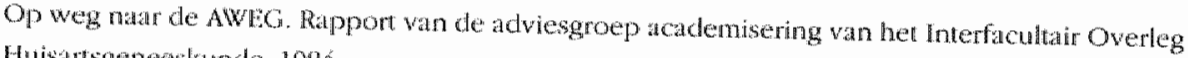
Huistrisgencestunde, 198 i

$\| 2$

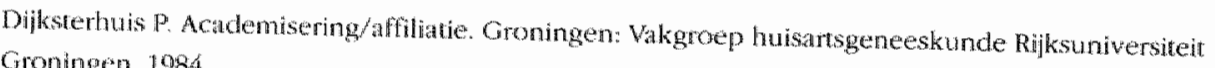
Groningen, 1984

13.

Bnuns CP, Noordhoff KH, Verdenius: W. Een Jatr universiaire groepspraktijk te Groningen. Huisarts Wet $11970 ; 13: 281-6$

14.

Deen KJ wan. Edinburgh Uniwersity Practice Teaching Unit. Huisats Wet 1961; 4: 78-9 
Hanken AJ, Meuten $\mathrm{H}$ wan der. Samenwerking tussen universitei en eerste lijn bedrijfskundig benaderd. red Contact 1987; $39: 1236-8$

6

Acijer IS, Schadé E. Van gastdocent tot UHP-arts: de ontwikkeling wan de academisering van de huisarts:eneeskunde. Huisarts wet 1992; 35: 29-31.

7

30oth $\mathrm{C}$. Reseatrh and the general practitioner. Br Med.) 1987; 295: 1614-9

18

Herber CP. Why family practice research? Can Fam Physician 1991; 37:335-8

19

Jagnon FA, Susak LE, Goulet FE. Getting started in fanily research (part 1). Can Fan Physician 1991; 37 : $596-601$

20

Gagnon FA, Susak LE, Goulet FE. Getting started in fanily research (part 2). Can lam Physician 1991; 37: 850-4

21

Murphy E, Spiegal N, Kinmonth AL. "Will you help me with my research" Gaining access to primary care settings and subjects. Brit J Gen Pract 1992; 42: 162-5

22

Silagy CA, Carson NE. Factors inflecting the level of interest and activity in puimary care research anong general practitioners. Fam Pract 1989; 6:173-6

23

Borgiel AEM, Dunn EV, Lamont CT, et al. Recruiting family physicians as participants in research. Fan Pract $1989 ; 6: 168-72$

24

Rudnick $\mathrm{KV}$, Walter $\mathrm{MD}$, Spizer $\mathrm{O}$, Pierce J. Comparison of at private family practice and a university teaching practice. J Med Ed 1976; 51 : 395-402

25

Rapport van de subcommissie gezondheids(zorg)wetenschappen, Koninklike Nederlandse Academie van Wetenschappen, 199 i.

26

Eijk JThM van, Gublibels JW. Wetenschappelijk onderzoek in de huisartsgeneeskunde. 2e druk. Lelystad: Medirekst, 1987

27

Knotnerus JA, Wet HCW de. Effectiviteitsonderzoet in de luisartspraktijk. Huisants Wet $1987 ; 30: 49,50-3,72$ $5,116.9$

28

Stoffers $\mathrm{HEH}$, Kaiser $\mathrm{V}$. De uitvoering van patiëntgebonden aandoeningsgericht wetenschappelijk onderzoek in de huisartspraktijk. In: Es JC van, Mandema E, Olthuis G, Verstraete M. Het Medisch Jaar 1990. Utrecht/Antwerpen: Bohn, Scheltema \& Holkema, 1990; 92-107 


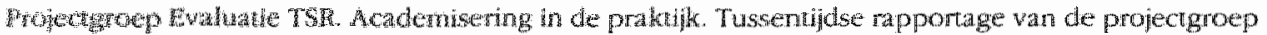

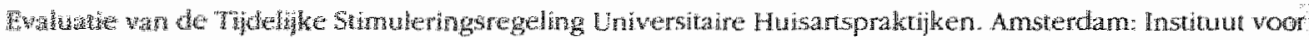
Thuspingenesestunde, 1990

30

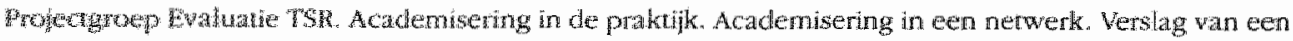

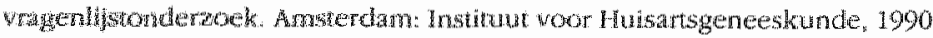

31

Thatectyop Evaluatue TSR. Academisering in de praktik. Academisering in zicht. Visies op de doelstellin-

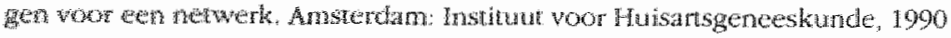

32

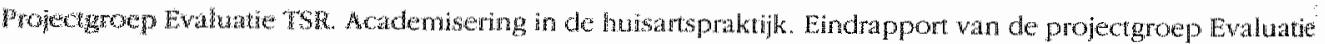

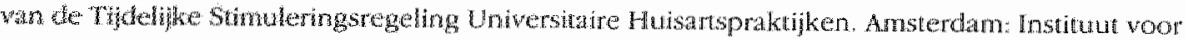

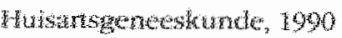

33

Begeleidingyscommissic Academisering Eerstelins Geneeskunde. Ontwikkelingsplan academisering huisarts-

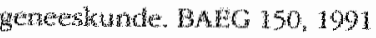

34

Ledec RMFF, Grebolder HFM, Breevoort EIMG. Wens en werkelijkheid in academische huisantspraktijken, discrepantes. Med Conad 1994(49); 41: 1278-1280

35

Spreawerherg $\mathrm{C}$. Academische werkpltatsen binnen en buiten het ziekenhuis. Med Contact 1994(49); 41:1273 


\section{HOOFDSTUK 3}

\section{HET HUISARTSGENEESKUNDIG}

\section{ACADEMISERINGSNETWERK MAASTRICHT \\ (HAM) NADER BESCHREVEN.}

\subsection{Inleiding}

Dit hoofdstuk beschrijf de wijze waarop aan de Rijksuniversiteit Limburg invulling is gegeven aan het academiseringsconcept huisartsgeneeskunde. Er wordi verondersteld dat deze ervaringen en de er aan ten grondslag liggende ideeën van belang zijn voor andere instituties. Het uiteindelijke resultat, het Huisartsgeneeskundig Academiseringsnetwerk Maastricht (HAM) en de wijze waarop dit netwerk gerealiseerd werd, worden derhalve gedetailleerd beschreven en verantwoord. Stilgestaan wordt bij werving en contractering van huisartspraktijken, financiën, contracten en werkplannen. Tenslotte wordt het verband besproken tussen de literatuur en theoretische onderbouwing enerzijds en de praktische uitwerking anderzijds.

\subsection{Voorgeschiedenis}

Vanaf de oorsprong van de Rijksuniversiteit Limburg is er aandacht geweest voor de relatie tussen de faculteit der geneeskunde en het regionale zorgveld. In de zogenamde Basisfilosofie ${ }^{i}$ stat in het hoofdstuk "Doelstelling van de faculteit der geneeskunde" geschreven:

"Een medische faculteit en bet mediscbe wetenschappelfik onderwis dienen bun dowstellingen te ontlenen aan de gezondbeidszong. De faculteit beeft wiet alleen de taak de riching en de kwaltheit van bet onderuifs te bewaken. Zij zal daarnaast ook bet syteem van onderwis en van gezondbeidszorg moeten belntloeden doordat ze, door wetenschappelik onderzoek en experiment, bijdraggt an een zo goed mogelife shuctur en werkwize wan de gezondbeidszorg."

"Gezten de ontwikkelingen die in de eerste lin plats bebben zal de Facultet der Geneeskude speciale andacbl en onderzoek moeten besteden aan de opleiding wan antsen wan bet eerste ecbelon".

"Samenutitend kan gesteld worden dat de Faculteit der Geneesknde van de Riksuniversiteit Limburg zich ten doel moet stellen door onderwis, onderzoek en actieve deelname aan de gezondbeidszorg bij te dragen aan de ontwikleling wan deze zorg...". 
"Cit de doelstellingen die angegeven zijn voor onderwijs en onderzoek volgt, dat de Faculteit der Geneeskunde actief en op een zo breed mogelijk terrein moet deelnemen aan alle vormen van gezondbeidszorg warin de artsen een rol van berekenis spelen. Natuurlijk dient de deetname aan die zong te benusten op een analyse van bet aanbod aan bestacande en wan de vrag naar niewwe voorzteningen in de regio. Meestal zal er alleen maar sprake kunmen zin van bet owememen wan of bet samen. werken in bestaande voorzteningen en activiteiten. Omdat deze maar gedeeltelij onder éên dak kunnen worden ondergebracht zal er bovendien gestreefd moeten worden naar organisatoriscbe bundeling wan geografiscb gespreide voorzieningen en activitetten."

Een nadere uitwerking van dit element van de basisfilosofie vindt in 1982 plaars in de vorm van een intern rapport "Academisering in de eerste lijn" 2 In dit rapport word reeds angegeven dat de $\mathrm{RL}$, mede gezien de ontwikkelingen die in de eerste lijn plaatsvinden, speciale aandacht en onderzoek moet besteden aan de opleiding van artsen in het eerste echelon. Academisering van de huisartsgeneeskunde wordt hiervoor noodzakelijk geacht en wel om de volgende vijf redenen:

- her morbiditeitspatroon in een huisartspraktijk wijkt aanzienlijk af van dat in een ziekenhuis;

- de wijze van probleem-oplossen is in de eerste lijn anders dan in de tweede lijn. Ze is naast ziekte-diagnostisch, ook sterk gericht op de persoon in zijn millieu en levensloop;

- in de eersteijn werkt een grote diversiteit van hulpverleners, zowel solistisch als in samenwerkingsverbanden. Het is belangrijk dat studenten kennismaken met deze diversiteit;

- studenten moeten diep doordrongen zijn van het feit, dat bij elk gezondheidsprobleem sprake is van een verwevenheid van somatische, psychische en millieufactoren. Didactisch gezien is de thuiszorg het meest in aanmerking komende werkgebied om aanstaande artsen in aanraking te brengen met dit fundamentele gegeven;

- er is nog relatief weinig bekend van de in de eerstelijn voorkomende gezondheidsproblemen en de ontwikkelingen daarvan. Ondezoek nat a ard en omvang van deze problematiek is van belang, mede om knelpunten in de gezondheidszorg op te sporen.

Op basis van dit rapport en gesprekken met vertegenwoordigers van het Ministerie van $O \& W$ werd in 1982 "de commissie academisering eerstelijnsgezondheidszorg en ambulante geestelijke gezondheidszorg" ingesteld. Deze, formeel door de directeurengeneraal voor het Hoger Onderwijs en Wetenschappelijk Onderwijs en voor de Volksgezondheid geinstalleerde commissie diende de besluitvorming van de ministers van O\&W en Volksgezondheid en van het bestuur van de Rijksuniversiteit Limburg voor te
bereiden.

In april 1983 verscheen het rapport van de commissie, in de volksmond het Rapport Sikkel (Dr.A.Sikkel was de voorzitter van deze commissie) genoemd 3 . Naast een historische terugblik bevat het rapport Sikkel een model-beschrijwing inzake de structur en de bekostiging van academisering van de eerste lijn.

Het rapport beschrijft een model bestaande uit een Facultaire Werkplaats eerstelijnsgezondheidszorg en een groep van partieel geacademiseerde praktijken. 
De werkplaats, bestaande uit een tweetal huisartspraktijken, zou moeten worden ondergebracht in een stichting, die vervolgens een overeenkomst sluit met de universiteit.

De Stichting Facultaire Werkplaats (SFW) zou facultaire medewerkers in stat stellen geintegreerd deel te nemen aan de patiëntenzorg.

De belangrijkste activiteiten van de werkplaats zijn:

- het verlenen van patièntenzorg;

- het geven van onderwijs, georiènteerd op de eerste lijn;

- het verrichten van onderzoek;

- het voorbereiden en uitvoeren van gezondheidszorgprojecten;

- het leveren wan een bijdrage aan de opleiding van huisartsen,

wijkverpleegkundigen en andere eerstelijns (para)nedische beroepen.

De Stichting Facultaire Werkplaats zou verantwoordelijk gesteld worden voor de verwerving van een tweetal praktijken.

Naast de Stichting Facultaire werkplaats (SFW) zou een zogenaamde Stichting Academisering in de Eerste Lijn (SAEL) worden opgericht; de SAEL vormt een platform voor overleg tussen universiteiten en het veld en vervult tevens de functie van melden regelkamer ten aanzien van partieel geacademiseerde praktijken.

Via deze stichting zou de universiteit haar opties op het gebied van onderwijs en onderzoek aan het eerstelijns-veld bekend kunnen maken, terwijl diezelfde eerstelijn in de gelegenheid is opties aan de faculteit(en) bekend te maken.

De huisartsen reageerden reeds in 1981 op de, in de basisfilosofie beschreven, universitaire plannen. Een officiële standpuntbepaling van het bestuur van de PHV (Plaatselijke Huisartsvereniging) Maastricht 4 werd in april 1981 in Medisch Contact gepubliceerd.

Het belangrijkste lijkt de waar te nemen schaalvergroting van de tweede lijn, zonder dat deze ingegeven is door een duidelijk omschreven behoeftebepaling.

"Voor de eerste lijn worden tot nog toe op geen enkele wijze vernimende omstandigbeden geschapen, gebaseerd op de veranderde "geacademueende" inboud van taak en functie, wardoor wij zouden kunen komen tor een wibreiding van mankracbl en mogelijkbeden om mede daardoor een gelijkuadrdige partner te kunen blifon voor de tweedelins gezondbeidszorg."

Samenvattend wordt vervolgens geconcludeerd dat voorwardenscheppende beleidsbeslissingen voor de eerste lijn een conditio sine qua non zijn om tot verdere ontwikkelling te komen.

"Zo niet, dan zal de aawwezigheid van de faculteit eerder een belemwerende dan een stimulerende werking bebben."

Het heeft tot 1985 geduurd alvorens concreet op de uitnodiging van de basisfilosofie werd ingegaan. Dit is in het kader van de totalle procesgang verklaarbaar.

Vanaf 1974 heeft de vakgroep huisartsgeneeskunde nadrukkelijk geparticipeerd aan het proces van ontwikkeling van de Medische Faculteit. In datzelfde jaar werd de eerste leerstoel Huisartsgeneeskunde officieel ingesteld. Onderwijsontwikkeling was in de jaren 1974 - 1980 dan ook de primaire taakstelling van de vakgroep. De roep om 
academisering van het hutsartsgeneeskundig veld was wel degelik aanwezig, maa werd pas ech manifest vanaf het begin vam de tachtiger jaren. De organisatie van he symposium Faculteit en Eerste Lijn door de vakgroepen huisartsgeneeskunde en Sociale Psychatrie in 1980 was typerend voor deze manifest geworden aandacht en heeft deze ook in hoge mate versterkt.

De nota's "Academisering in de eerste lijn" 2 en "Integraal plan woor universitaire parti cipatie in de regionale gezondheidszorg" ', alsmede het "Rapport van de Commissie Academisering Eerstelijngezondheidszorg en Ambulante Geestelike Gezondheids zorg" 3 beschrijven uitvoerig het kader, wan waaruit de academisening huisartsgenees. kunde in Maastricht gestalte heeft gekregen.

De jaren 1982 tot 1985 kunmen ten aanzien van de academisering huisartsgeneeskun de gekenschetst worden als een periode van toenemend pragmatisme. Interne discussies in de universiteit/faculteit en overlegsituaties met de huisartsen in de (directe) regio volgden elkaar in hoog tempo op. Vanaf deze periode wordt er ook gesproken van het academiseringsmodel, bestaande uit 2 cirkels.

\section{AWEG's en SAEL-praktijken: de academisering $1^{\mathbf{e}}$ en $2^{\mathbf{e}}$ cirkel}

In het rapport-Sikkel worden twee academiseringsstereotypen nader beschreven, te weten de AWEG (Academische Werkplaatsen Eerstelijns Gezondheidszorg oftewel de Stichting Facultaire Werkplaats) en de zogenaamde SAEL-praktijken.

\section{Artikel in Limburgs Dagblad, 9 november 1983}

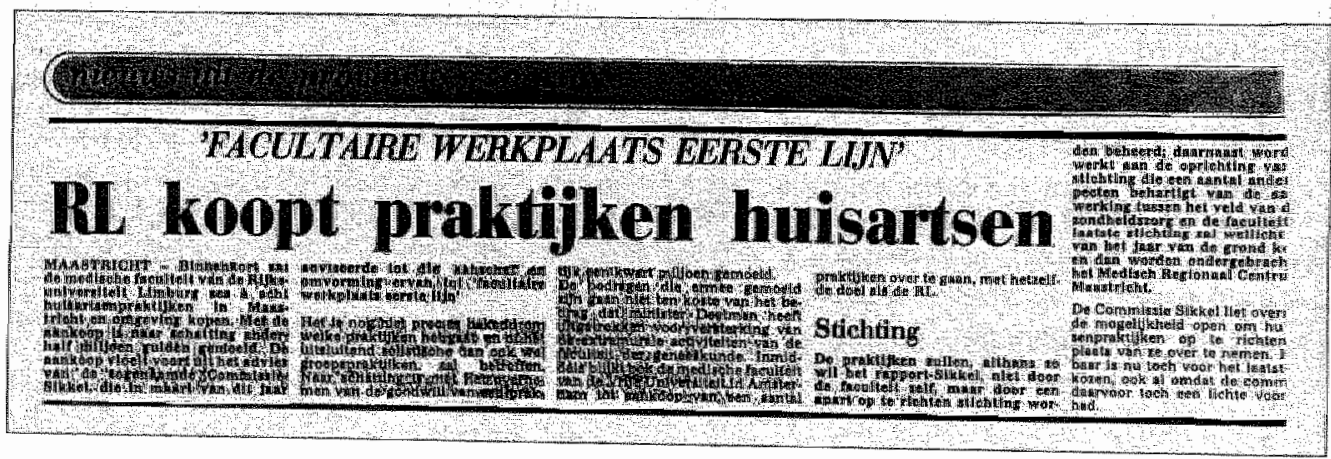

\section{AWEG-praktijken}

De nota's en zelfs de regionale pers (Limburgs Dagblad 9-11-1983) gaven aan dat de universiteit een beperkt aantal huisartspraktijken zou opkopen, de Academische Werkplaatsen Eerstelijns Gezondheidszorg.

De huisartsen zouden in loondienst van de universiteit (of van een onafhankelijke stichting, de Stichting Facultaire Werkplaats) komen en er zouden tevens medewerkers van de vakgroep huisartsgeneeskunde aan de gezondheidszorg worclen toegevoegd. Daar war voorheen drie huisartsen de gezondheidszorg-taak verrichten, daar zouden nu bijwoorbeeld wijf huisartsen deze taak verdelen, en daamaast onderwijs en onderzoekwerkzaamheden verrichten. De beleidmakers van toen noemden deze academiseringsvorm de zogenaande 1 cirkel. 


\section{SAEL-praktijken}

Natast de werving van eerste cirkel-praktijken zou de zogenaamde Stichting Academisering Eerste Lijn (SAEL) ook de wervingsfunctie vervullen ten behoeve van het aantrekken van huisartspraktijken, die in een samenwerkingsverband met de universiteit bereid zouden zijn partieel bijdragen te leveren aan het universitaire onderwijs- en onderzoekprogramma. Deze SAEL-praktijken werden de ze cirkel-praktijken genoemd:

De samenwerking heeft uiteindelijk een andere invulling gekregen dan de beleidsnota's voorspelden. De AWEG-gedachte, alhoewel theoretisch van grote schoonlheid, kon geen voedingsbodem vinden. Acquisitie van een huisartspraktijk (gezondheidscentrum) door de universiteit bleek structureel en financieel niet haalbaar, terwijl tevens slechts zeer moeizaam de aansluiting met de andere eerstelijns-disciplines gevonden kon worden. Ook de vraagstukken met betrekking tot de verantwoordelijkheid voor het zorgproces waren ingewikkeld.

Tevens bleek dat de Stichting Academisering Eerste Lijn (SAEL) niet in staat was de wervingstak van de partieel geaffilieerde praktijken op adequate wijze te vervullen.

Het is goed te weten dat de SAEL een andere kijk op de academiseringsplannen ontwikkelde dan hetgeen de faculteit der geneeskunde zinvol achtte. Het is logisch dat de SAEL, samengesteld uit vertegenwoordigers uit de kerndisciplines van de eerste lijn, een academiseringsgedachte ontwikkelde voor de eerste lijn als geheel. Dit betekent dus een academisering, niet alleen van de huisartsgeneeskunde, maar ook in ieder geval van de wijkverpleegkunde, de gezinszorg en het maatschappelijk werk. Deze gedachte, die later niet haalbaar bleek te zijn, was in de eerdere universitaire plannen wel degelijk zichtbaar.

Voortdurend was er sprake van de academisering van de eerstelijns gezondheidszorg met een, vanuit de behoefte van de Faculteit der Geneeskunde bekeken, natuurlijke voortrekkersrol voor de huisartsgeneeskunde.

Al spoedig bleek echter dat de uitstraling naar de andere eerstelijns disciplines een indirecte zou moeten zijn, enerzijds vanwege de beperkingen in financiële zin, anderzijds door het onderwijs- en onderzoekprofiel van de geneeskundige faculteit, gericht op de opleiding van artsen.

Deze twee gegevens leidden aan de kant van het faculteitsbestuur tot de volgende conclusies:

1

De wervingstaak wan toekomstige geacademiseercle praktijken wordt teruggehaald naar de faculteit c.q. de vakgroep huisartsgeneeskunde. De SAEL houdt zich voortaan bezig met de ontwikkeling van multidisciplinaire onderwijs- en onderzoeksprojecten met een draagvlak binnen de eerste lijn.

2

De faculteit streeft naar het tot bloei brengen van academiseringsrelaties met huisartsen op basis van een andere invulling dan het door de commissie Sikkel geintroduceerde eerste en rweedle cirkelmodel. Acquisitie van huisartspraktijken is geen optie meer, terwijl tevens het accent van academisering verlegd wordt van de eerste lijn náar de huisartsgeneeskunde. 
De nieuwe definities zijn nu als volgt.

Een $1^{\text {e }}$ cirkel academiseringspraktijk is, gezien de brede taakstelling een over het alge meen grotere setting (groepspraktijk, gezondheidscentrum of associatie), alwaar een samenwerking wordt aangegaan ten aanzien van de drie gebieden onderwijs, onder zoek en registratie van patientgebonden gegevens.

De 2 e cirkel-praktijken zijn kleiner wan omvang en concentreren zich in principe op ên van de eerder genoemde hoofdgebieden.

De omvang van de samenwerking varieert in de 1 e cirkel van 0.5 Fte tot 1.0 Fte per praktijk, terwijl de gemiddelde omvang bij de 2 e cirkelpraktijk ca. 0.2 Fte betreft.

(1 Fte $=1$ full-time equivalent).

Naast de $1^{\text {e }}$ en $2^{\mathrm{e}}$ cirkelpraktijken zouden er affliatiepraktijken geworven worden Onder affiliatie wordt in de Maastrichtse filosofie verstaan een kortopende samenwer king tussen huisarts(praktijk) en universiteit op basis van een specifiek onderwijs- of onderzoelksproject.

Tussen deze drie vormen van samenwerking was niet een verondersteld verschil in kwaliteit tussen de praktijken matgevend. De benadering was veeleer pragmatisch; de wederzijlse mogelijkheden en perspectieven om gemakkelijk en zonder te forceren op basis van wederzijds voordeel een relatie aan te gaan, bepaalden de loop der dingen.

Inmiddels was de faculteit der geneeskunde van de Rijksuniversiteit Limburg in het kader van de zogenaamde TVC-operatie (Taakverdeling en Concentratie van de landelijke geneeskundige faculteiten) door het Ministerie van Onderwijs aangewezen zich te profileren op het gebied van de eerstelijns geneeskunde. Vanuit een extra geldstroom, het Vernieuwingsfonds Extramurale Gezondheidszorg, kwamen extra finan ciële middelen beschikbar.

Deze ontwikkeling staat uitvoeriger beschreven in het artikel "Academisering van huisartspraktijken" 6

Kort samengevat kent de ontwikkeling van de academisering huisantsgeneeskunde in Mastricht 4 periodes:

$1974-1982$

$1982-1985$

$1985-1990$

1.990 - heden
De periode van de theoretische onderbouwing van het academiseringsconcejt en de verkenning van het eerstelijns veld

Het toenemend pragmatisme; de concept-ontwikkeling is gericht op spoedige contractering van geacademiseerde praktijken, volgens een. bijgesteld cirkel-model

De werving van praktijken en de verdere uitdieping van het ontwikkelde concept (passend bij de Maastrichtse filosofie: probleemgestuurd en aan de hand van concrete casuistiek $)^{7,34}$

Toenemende aandacht voor nadere uitwerking, evaluatie en a anscherping van het academiseringsconcept.

In november 1993 en 1994 vonden de jaarlijkse workshops plaats van het academiseringsnetwerk van de Rijksuniversiteit Limburg. In 1993 werd gekozen voor een verdere uitdieping van het onderwerp academisering aan de hand van de inaugurale redes van de hoogleraren huisartsgeneeskunde van deze universiteit. 
Onder de titel "Academisering als Beleidsinstrument; dagelijks werk op niveau of geleerd gedoe?" besprak de directeur Preventie, Algemene Gezondheidszorg en Opleidingen wan het Ministerie van WVC de historie en de noodzaak van de academisering van de eerste lijn. Naast aandacht voor de definitie-problematiek van academisering werd vastgesteld dat academisering noodzakelijk is zowel voor onderwijs, opleiding en onderzoek als voor de verdere ontwikkeling van het vakgebied. Het netwerkmodel lijkt de beste vorm, waarin de academisering van de huisartsgeneeskunde gestalte kan krijgen. Aandacht voor landelijke coördinatie van alle academiserings-ontwikkelingen wordt essentieel geacht. Een voorwaarde voor het slagen van de academiseringsplannen is de succesvolle combinatie van patièntenzorg met de academische taken. Het Ministerie van WVC heeft voldoende gestimuleerd en de tijd lijkt aangebroken dat ook de academisering van de eerste lijn regulier ondercleel wordt van de zogenaamde Rijksbijdrage-regeling. De netwerken moeten duidelijker maken wat ze doen in het kader van academisering en de behaalde successen uitdragen. Daarbij moet er aandacht zijn voor outputmeting, niet alleen van de universitaire taken op het gebied van onderwijs en onderzoek, maar ook ten aanzien van de effecten op de patiëntenzorg.

In 1994 stond de ontwikkeling van de patiëntenzorg in academische praktijken centraal. Diverse geacademiseerde huisartsen demonstreerden "gezondheidszorg-projecten". Als centraal spreker was de voormalig staatssecretaris Prof.Mr.J.Cohen bereid gevonden stil te staan bij de financiering van extramurale academische netwerken. De diverse financieringswijzen (uit de Rijksbijdrage voor academische ziekenhuizen, een "eigen" rijksbijdrage voor extramurale werkplaatsen of subsidiering vanuit de centrale overheid of vanuit de ziekenfondstrad) werden geanalyseerd. Helaas lijkt geen van deze varianten op korte termijn haalbaar.

Zo begint deze inleiding met de "basisfilosofie" van de Rijksuniversiteit Limburg en wordt deze geëindigd met de workshop van de academische praktijken, zoals georganiseerd in november 1994.

\subsection{Nadere begripsbepaling}

In paragraf 1.2 werd dieper ingegaan op de begrippen academisering en affiliatie. Ook in het Huisartsgeneeskundig Academiseringsnetwerk Maastricht (HAM), hebben deze begrippen een bepaalde betekenis gekregen.

"Academisering" betekent dan de gestructureerde / geïnstitutionaliseerde samenwerking tussen universiteit en huisartspraktijken, waarbinnen onderling samenhangende en vooraf overeengekomen activiteiten plaatsvinden ten behoeve van (de integratie van) wetenschappelijk onderwijs en onderzoek en patiëntenzorg.

De voor deze samenwerking noodzakelijke infrastructuur wordt vervolgens het "academiseringsnetwerk" genoemd.

"Affiliatie" wijkt in zoverre af van academisering, dat bij affiliatie cle nadruk niet direct ligt op de integratie van onderwijs of onderzoek met de patiëntenzorg, maar meer op de uitvoering van huisartsgeneeskundig onderwijs en onderzoek op het gewenste 
kwalitatieve niveau. Er is een verschil in omvang, intensiteit en continuiteit van de samenwerking tussen de universiteit en de geaffilieerde huisarts(praktijk). De gemaakte afspraken gelden doorgaans voor een specifiek onderwijs- of onderzoeksproject en slechts voor de duur van dat project (variërend wan 1 tot 3 jaar). Dat laat onverlet dat vele "affiliatie-huisartsen" langdurig aan diverse projecten hun bijdrage verlenen of hebben verleend.

Meer nog clan de "affiliatie-huisarts" client de "academische huisarts" te voldoen aan eisen op het gebied van de infrastructuur en de kwaliteit van de patiëntenzorg. Bif infrastructuur kan dan gedacht worden aan voldoende capaciteit bij huisarts en assistentie, praktijk- en onderwijsruimte, automatisering en registratie en informatie in de vorm van praktijkfolders en -verslagen. Op het gebied van de patiëntenzorg gaat het dan bijvoorbeeld om het (systematisch) gebruik van de NHG-standaarden, het beleid ten aanzien van de thuiszorg, kwaliteitsbevordering en toetsing.

De academische huisarts heeft bovendien een actieve ral in de directe beïnvloeding van het beleid van de vakgroep huisartsgeneeskunde op her gebied van onderwijs, onderzoek en ook beleidsmatig. Deze beïnvloedling geschiedt door de implementatie van nieuwe inzichten in het onderwijs, het genereren van onderzoekshypothesen en zo mogelijk door actieve deelname aan de beleidsorganen van de vakgroep (onderwijsgroep, researchgroep en dagelijks bestuur) en eventueel van de faculteit.

De definities van en verschillen tussen academisering en affiliatie zijn niet sluitend en ook niet voor iedereen even inzichtelijk. Sommigen verklaren de verschillen tussen academisering en affiliatie dan ook primair aan de hand van de "financieringsbron".

De indruk bestaat dat bij de ontwikkeling van het HAM, zeker in de begin jaren tachtig de nadruk sterk gelegen heeft op discussies over dergelijk definitie-kwesties. Vanaf $1985 / 1986$ is de aandacht verlegd naar een meer pragmatische benadering. Mer "vallen en opstaan" leren wat academisering zou kunnen zijn, leek toen beter dan van te voren te proberen het "vallen en opstaan effect" te voorkomen.

\subsection{Werving, contractering en omvang van het HAM}

De werving van te acaderniseren huisartspraktijken voltrok zich in tegenstelling tot de in het rapport Sikkel geformuleerde twee cirkels (Stichting Facultaire Werkplaats Eerstelijnsgezondheidszorg en Stichting Academisering Eerste Lijn) via viff fasen:

1

Academisering van praktijken van reeds bij de vakgroep werkzame huisartsen.

2

Contractering van geautomatiseerde praktijken met een primaire taak op het gebied van het registreren van patiëntgegevens.

3

verdere uitbreiding van het netwerk in de vorm van een open werving onder alle 
huisartsen in de facultaire regio (Limburg en Zuid-Oost Brabant en deels ook Vaanderen).

4

Werving van huisartspraktijken ten behoeve van ontwikkelingstaken op het gebied van de huisartsopleiding, ingegeven door de Tijdelijke Stimuleringsregeling Universitaire Huisartspraktijken (TSUH).

5

De laatste aanpassingen van het netwerk ten gevolge van uitval wan eerder toegetreden huisartspraktijken.

De diverse ontwikkelingsfasen van het HAM worden in dit hoofdstuk kort beschreven.

\subsubsection{Contractering praktijken $1^{\mathrm{e}}$ fase}

Zoals hierboven aangegeven werd in de periode $1985 / 1986$ gestart met de contractering van geacademiseerde huisartspraktijken.

Er waren reeds vanaf 1975 huisartsen aan de vakgroep huisartsgeneeskunde verbonden, met de intentie in de verdere toekomst als geacademiseerde huisarts werkaam te zijn. Deze huisartsen behielden hun aanstelling bij de vakgroep huisartsgeneeskunde, mar ontvingen een ander (een geacademiseerd) takakprofiel. In het HAM wordt dit de academisering $1 \mathrm{e}$ fase genoemd. De geacademiseerde huisartsen le fase houden zich in principe bezig met alle gedefiniexde hoofdtaken van academisering, te weten onderwijs, onderzoek, registratie ten behoeve van het Registratienet Huisartspraktijken en gezondheidszorgontwikkeling. De afgesloten contracten hebben een omvang, varierend van 0.2 Fte tot 1.3 Fte per geacademiseerde huisartspraktijk.

In de eerste fase werden 8 huisartspraktijken in het HAM-netwerk opgenomen.

\subsubsection{Contractering huisartspraktijken $2^{\mathrm{e}}$ fase}

Toen bleek dat de werkzaamheden ten behoeve van het Registratienet Huisartspraktiken (RNH) 16,29,32 achterbleven bij de beoogde doelstelling wend door de Rijksuniversiteit Limburg ingegaan op een reeds eerder gedwan verzoek van de zogenaande gebruikersvereniging Orghis. Deze vereniging van huisartsen die hun praktijk automatiseerden met het systeem Microhis waren bereid hun praktijk in te zetten in het netwerk en te registreren volgens de gedefinieerde RNH-begrippen. Vijf praktijken werden woor $0.1-0.3$ fte in het netwerk opgenomen met een exclusieve inhoudelije inzet ten behoeve van het RNH.

Naast basale en projectregistraties ten behoeve van het RNH, zou ook het coördinatorschap wan het RNH in de 2 e fase nadere invulling krijgen, met speciale aandacht voor het automatiseringsproces. 


\subsubsection{Contractering huisartspraktijken $3^{\mathrm{e}}$ fase}

Voor de verdere uitbouw van het academiseringsnetwerk met name ten behoeve v onderwijsactiviteiten, werd in 1988 in de regio's Limburg en Zuid-Oost Brabant ef open werving gestart.

Alle huisartsen werden aangeschreven met als belangrijkste vraag of er belangstellin bestond voor participatie aan het HAM. Van de aangeschreven 530 huisartsen, wed zaam in 285 praktijksettings respondeerde $40.5 \%$ (116 praktijken).

Van de respondenten bleek $33.6 \%$ (39 praktijken) geinteresseerd in daadwerkelitik participatie aan het netwerk.

De belangstelling voor de inhoudelijke onderdelen wordt in tabel 3.1 weergegever Opvallend was het gegeven dat bijna de helft van de geïnteresseerde huisartsen geet voorkeur had voor een bepaald inhoudelijk takenpakket.

In maart 1988 werd voor de geïnteresseerde huisartsen een eerste academiserings workshop georganiseerd. Daarin werd uitgebreid aandacht besteed an het academ seringsproces in het algemeen en de rol van huisartsen bij onderwijs, onderzoek en registratie in het bijzonder.

Na de workshop werden alle praktijken door een delegatie van het bestuur van dis vakgroep huisartsgeneeskunde gevisiteerd, waarna door het bestuur de uiteindelijks selectie werd verricht. Deze selectie vond plaats op grond vain ervaring met onderwili en onderzoek, getoonde interesse en motivatie, en de aanwezigheid van adequate praktijkvoorzieningen.

Uiteindelijk werden 11 pralktipken aan het HAM toegevoegd.

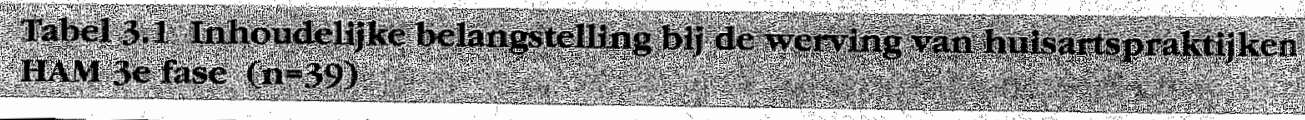

\section{Onderwerp met primaire interesse}

van de huisarts(en)

Aantallen absolluut

Kolompercentage $(\%)$

Onderzoek exclusief

Onderwijs exclusief

Registratie-qctiviteitten exclusief

Onderzotik en onderwijs

Onderzoek en registrattie

Onderwijs en registratie. 


\subsubsection{Contractering huisartspraktijken $4^{\mathrm{e}}$ fase}

In de eerste drie fasen van her academiseringsproces werd met betrekking tot de onderwijsactiviteiten nadrukkelijk geworven voor de participatie van praktizerencle huisartsen aan onderwijs in het basiscurriculum van de Faculteit der Geneeskunde van de Rijksuniversiteit Limburg. Bijdragen aan de huisartsopleiding kon geen onderdeel uitmaken van de afgesloten contracten en werkplannen, aangezien de financiering van het netwerk plaatswond met middelen van het Ministerie van $O \& W$, het zogenaamde Vernieuwingsfonds. Door een additionele financiering vanuit het Ministerie van WVC, de Stimuleringsregeling Universitaire Huisartspraktijken (de "UHP-regeling") werd het mogelijk nieuwe huisartspraktijken aan het HAM toe te voegen met een specifieke taakstelling op het gebied van de huisartsopleiding.

Op de diverse financieringsstromen wordt in dit hoofdstuk nog teruggekomen. Met de nieuwe middelen werden wijf nieuwe huisartspraktijken aan het netwerk toegevoegd. Eén, reeds aan het netwerk participerende praktijk kreeg een uitbreiding van de reeds overeengekomen taakstelling.

\subsubsection{Contractering huisartspraktijken $5^{\mathrm{e}}$ fase}

In de viffde en vooralsnog laatste fase van het academiseringsproces traden vier nieuwe huisartspraktijken toe. De mogelijkheden tot toetreding ontstonden doordat drie geacademiseerde huisartspraktijken hun participatie aan het HAM beëindigden. De nieuwe geacademiseerde huisartspraktijken houden zich woornamelijk bezig met taken ten behoeve van het Registratienet Huisartspraktijken, wetenschappelijk onderwijs en in mindere mate met wetenschappelijk onderzoek.

\subsubsection{Omvang HAM anno 1994}

Uiteraard hebben er zich in de jaren 1987 tor 1994 wijzigingen voorgedaan in de bezetting van het netwerk. Naast personele wijzigingen door vertrek van zittende huisartsen naar andere praktijken of uitbreidingen van de praktijken zelf, hebben in totaal drie huisartspraktijken hun academiserings-samenwerking met de vakgroep huisartsgeneeskunde beëindigd. De belangrijkste reden van beëindiging van de relatie betrof het tijdsprobleem. De combinatie van de patiëntenzorg met de wetenschappelijke taken is zeer arbeidsintensief.

Het totale netwerk bestaat derhalve uit 30 huisartssettings, waarvan

- 9 gezondheidscentra

- 13 duo- of groepspraktijken

- 8 solo-praktijken

In het HAM zijn in totaal 83 huisartsen werkzaam, waarvan er 16 op enigerlei wijze en met behulp van verschillende financieringsmethoden gedetacheerd zijn vanuit de Rijksuniversiteit Limburg. In appendix A wordt een overzicht gegeven van de anno 1994 aan het HAM participerende huisartspraktijken.

De geografische spreiding van de aan het HAM participerende huisartspraktijken wordt in figuur 3.2. weergegeven. 
Bij de ontwikkeling van het netwerk was de realisatie van een zekere spreiding van de netwerkpraktijken over de universitaire regio geen geformuleerd uitgangspunt. Voor de uitvoering van de diverse taken, met name voor het onderwijs, is het voordelig dat er een concentratie van HAM-praktijken bestaat binnen een straal van circa $30 \mathrm{~km}$ vanaf de universiteit.

Ook ten behoeve van de conmunicatie biedt dit voordelen. Dat laat onverlet dat ook de op grotere afstand gelegen praktijken de inhoudelijke werkplannen volledig en nat volle tevredenheid (kunnen) uitvoeren.

\section{Miguni 3.2 Geografische spreiding van de praktijen over de universitaire regio}

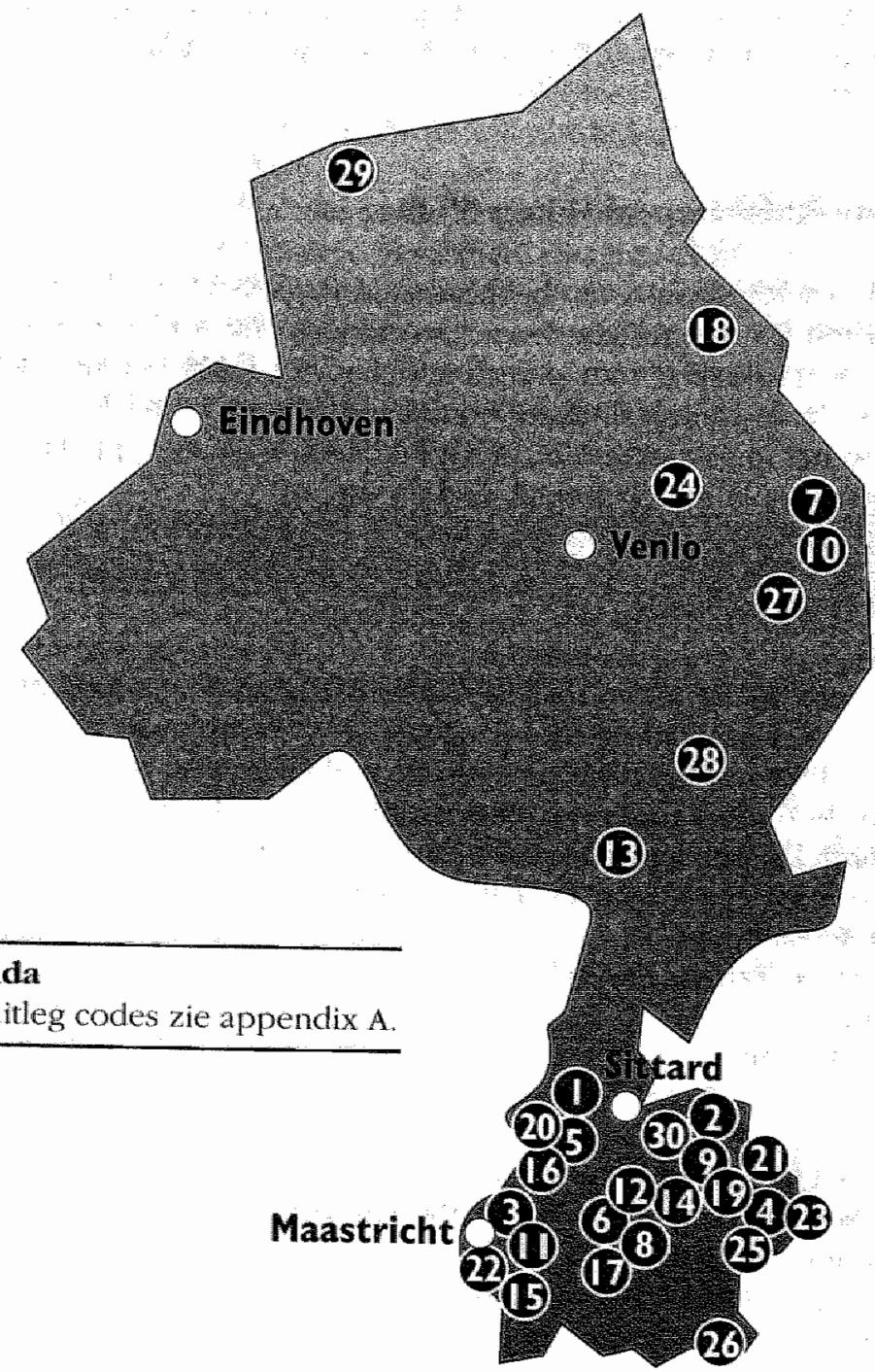




\subsection{Financiering van het HAM}

\subsubsection{Inleiding}

De realisatie en instandhouding van een omvangrijk en professioneel functionerend huisartsgeneeskundig academiseringsnetwerk zijn voor een belangrijk gedeelte ahankelijk van de aanwezige financiele mogelijkheden. Het is onjuist te veronderstellen dat de structurele samenwerking tussen huisartsen en universiteiten in academiseringsnetwerken tot stand zou kunnen komen zonder de noodzakelijke financiële impulsen. Een adequate vergoeding van de tijdsinvestering van de huisartsen en de, in de praktijk te maken, onkosten is dan ook een essentiële voorwairde:

De Facuiteit der Geneeskunde van de Rijksuniversiteit Limburg heeft de noodzaak van een adequate financiering onderkend en verschafte in 1986 vanuit het zogenaamde Vernieuwingsfonds additionele middelen. Het Vernieuwingsfonds werd door het Ministerie van $O \& W$ toegekend aan twee Nederlandse universiteiten, de Rijksuniversiteit Limburg en de Vrije Universiteit van Amsterdam. Deze, vanuit de oorsprong tijdelijke, subsidie stelde de Faculteit der Geneeskunde in staat haar specifieke opdracht in het kader van de eerstelijns-profilering ten uitvoer te brengen. In 1991 slaagde de faculteit er in structurele toekenning van het vernieuwingsfonds te verkrijgen, mede doordat een inhoudelijke visitatie door een "international board" van deskundigen op het gebied van extramurale profilering tot een positjeve beoordeling leidde 34 .

Het HAM wordt voor een belangrijk gedeelte gefinancierd uit het Vernieuwingsfonds. Aangezien het Vernieuwingsfonds primair bedoeld was ten behoeve van facultair onderwijs en onderzoek in het kader van de eerstelijnsprofilering, bleef de huisartsopleiding vooralsnog buiten beschouwing. Dat was mede een reden voor het Ministerie van WVC om over te gaan tot de toekenning van de zogenaamde Stimuleringsregeling Universitaire Huisartspraktijken (de "UHP-regeling"). Deze tijdelijke stimulans gold voor de periode $1987 \mathrm{tol} / \mathrm{met} 1994 \mathrm{en}$ is derhalve na afloop van het jaar 1994 beëindigd. Indien er geen vervangende regeling wordt afgekondigd komen belangrijke delen van het HAM in gevaar. De minister heeft inmiddels de Ziekenfondsraad gevraagd de verplichtingen in het kader van deze regeling tijdelijk over te nemen, ter voorbereiding op een definitieve regeling.

\subsubsection{Financiële middelen}

De financiering van het HAM vanuit het Vernieuwingsfonds en de Stimuleringsregeling Universitaire Huisartspraktijken start formeel op 1 januari 1987.

De middelen van het Vernieuwingsfonds worden door het ministerie van O\&W toegekend aan de Faculteit der Geneeskunde van de Rijksuniversiteit Limburg en derhalve opgenomen in de facultaire begroting. De Stimuleringsregeling UHP wordt vanuit het ministerie van WVC rechtstreeks aan de vakgroep huisartsgeneeskunde toegekend. Het bestuur van de Faculteit der Geneeskunde heeft vanaf 1987 een aantal structurele maltregelen genomen ter financiering van het HAM; daarnaast zijn twee separate toewijzingen gedaan ter financiering van investeringen in de bouw van geacademiseerde huisartspraktijken en voor de noodzakelijke automatisering in de betreffende praktijken. 
De structurele maatregelen betreffen enerzijds de financiering van 9.6 Fte personel lasten en anderzijds de vergoeding van in het netwerk gemaakte onkosten.

De stimuleringsregeling werd jaarlijks toegekend op basis van een, bij het ministeri ingediende evaluatie over het voorgaande jaar en een wraagbegroting voor het volgen de jaar. De begroting beval zowel een personele als een materiële component. In de startjaren 1987/1988 is eveneens bijgedragen aan de financiering van verbouwingen: aanpassingen in geacademiseerde praktijken.

Uit de tabel 3.3 blijkt dat het HAM in de periode 1987-1994 (een periode van 8 boekja: ren) een totale financiering heeft ontvangen van $\mathrm{Fl} .10 .776 .000=$, hetgeen een gemid: delde jaarlijkse bijdrage betekent van ca. Fl. 1.300:000:

Hoewel deze bijdrage aanzienlijk is, moeten de hier genoemde bedragen wel in het juiste perspectief gezien worden. Het betreft enerzijds een groot netwerk bestaande uit 30 huisartssettings met ruim 80 huisartsen, van waaruit voor 9.6 Fte bijdragen wor den geleverd aan het onderwijs- en onderzoekprogramma van de Rijksuniversitei Limburg. Anderzijds moet de vergelijking gemaakt worden met andere academiseringsnetwerken. De geacademiseerde afdelingen van de academische ziekenhuizen kunnen als mogelijk referentiekader beschouwd worden. De financiering van acade. mische ziekenhuizen geschiedt via de zogenaamde Rijksbijdrage Academische Zieker huizen vanuit het Ministerie van Onderwijs en wetenschappen (O\&W). Het AZM (Academisch Ziekenhuis Maastricht) ontvangt in dit kader een jaarlijkse bijdrage van momenteel ruim Fl. 98.000.000 = (inclusief diverse opslagen). Het is echter onmogelijk zonder verdere differentiatie en specificatie dit bedrag te vergelijken met het financiêle perspectief van het HAM. 


\section{Boekjaar Onderwerp}
Bron Bedrag Toekenning Eenmalige Total (gemiddeld per boekjaar toekenning fìnanciering per jaar)

$1987-1992$ Vergoeding onkosten in de $\begin{array}{lllll}\text { geacademiseerde praktijken (exploitatie) } & \text { V: } \quad 192.000 \quad \text { jat } & \ldots & 1.152 .000\end{array}$

1993-1994 Vergoeding onkosten in de geacademiseerde praktijken (exploitatie), inclusief bijdrage aan apparatuur VE $222,000 \quad$ ja 44000

1987-1994 Vergoeding personele inzet van de geacademiseerde huisartsen van het HAM (9.6 Fle) VF $9600000 \quad$ Ja 7.680 .000

1988 Bijdrage aan verbouwingsactiviteiten in geacademiseerde praktijiken Vip $\quad 500.000$ ja 500.000

1989 Aanschaf computer-apparatuur HAM ten behoeve wan het Registratienet Huisartspraktijken (RNH)

1987 1994 Vergoeding personele inzet van de geacademiseercle huisartsen van het HAM

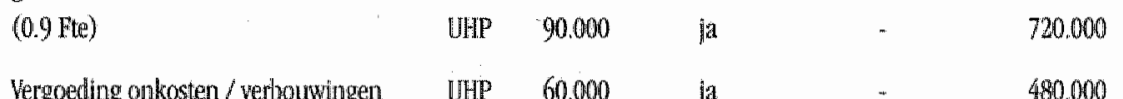

1987-1994 Vergoeding onkosten / verbouwingen

UHP 600000

480.000

Totwal over

pertiode

$1987-1994$

10.776 .000

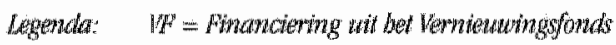

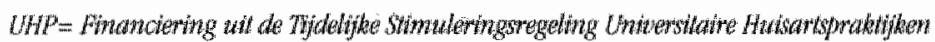

\subsubsection{Financiële vertaling naar de geacademiseerde huisartspraktijken van het HAM}

Teneinde de beschikbaar gestelde middelen op een efficiënte wijze te verdelen over de geacademiseerde praktijken zijn diverse financieringsmodellen nader uitgewerkt. De personele inzer van de huisartsen kan op verschillende wijzen worden gehonoreerd:

\section{prestatie tegen salaris}

de geacademiseerde huisarts levert inhoudelijke bijdragen aan onderwijs, onderzoek en/of huisartsopleiding en ontvangt daarvoor een honorarium van de Rijksuniversiteit Limburg wia een aanstelling bij de vakgroep huisartsgeneeskunde. De omvang van het werkplan van de betreffende praktijk bepaalt de aanstellingshoogte en dus het te verdienen salaris; 


\section{prestatie tegen prestatie}

de geacademiseerde huisarts levert bijdragen en wordt gecompenseerd doordat eefi medewerker van de vakgroep huisartsgeneeskunde in de praktijk van de huisarts eet gedeelte van de patiëntenzorg levert. De omvang van het werkplan bepaalt de mate van aanwezigheild van de RL-medewerker in de praktijk;

\section{prestatie tegen geld}

de bijdragen van de huisarts worden vergoed in de vorm van een geldelijke vergoe ding, niet zijnde salaris. De omvang van het werkplan bepaalt de hoogte van de gelde lijke vergoeding.

\section{outputfinanciering}

de bijdragen van de huisarts worden achteraf op basis van de daadwerkelijk geleverde prestatie in geld uitbetaald.

Het verschil tussen de genoemde beloningssystemen "prestatie tegen geld" en "output: financiering" verdient wellicht enige aandacht. In hoofdstuk 5 zal aan de hand van de economische organisatietheorieën duidelijk worden dat bij "prestatie tegen salaris" in wezen taakafhankelijke beloning bedoeld wordt. Niet de mate waarin gepresteerd wordt bepaald de hoogte van de beloning, maar de taak(omvang) staat centraal. Bij outputfinanciering wordt wel de prestatie centraal gesteld. De term prestatiebeloning zou dan ook wellicht duidelijker zijn.

Momenteel worden alle bovengenoemde beloningsmethodieken toegepast. Tabel 3.4 geeft de verdeling van de gebruikte beloningsmethodieken weer. Prestatie tegen salaris is nog veruit de meest toegepaste methodiek, met name omdat de aanstelling van geacademiseerde huisartsen als universitair medewerker de gelijkwaardigheid benadrukt, hetgeen in het kader van de netwerkfilosofie belangrijk wordt gevonden.

Prestatie tegen prestatie wordt met name toegepast in de geacademiseerde praktijken uit de 4 e fase. Doelstelling van de stimuleringsregeling universitaire huisartspraktijken was namelijk stafmedewerkers van de vakgroep huisartsgeneeskunde in de gelegenheid te stellen (partieel) in praktijken te laten functioneren. Vanuit dit uitgangspunt werd als snel gekozen voor de ruil van prestatie tegen prestatie.

Prestatie tegen geld wordt slechts in twee praktijken exclusief toegepast. Voor het overige worden cle prestaties van de geacademiseerde huisartsen via mengvormen van bovengenoemde beloningsmethodieken vergoed.

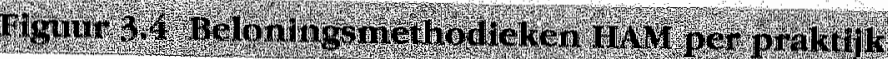

\section{Beloningsmethodiek}

Prostatie tegen salaris

Prestatie tegen preslatie

Prestatie tegen geld

Combinatie prestatie tegen saldais en outputfinanciering

Combinatie prostatie tegen prestatie en outputfinanciering

Combinatie prestatie tegen prestatie en geld $\mathbf{n}=\mathbf{3 0}$

8

2

2

12

3

3
Percentage

De genaemde belomingwamen uorden in be wolgende nader ander de lowpe genomen. 


\subsubsection{Prestatie tegen salaris}

Vooraf is met de praktijken overeengekomen welke kwantitatieve inzet maximaal geleverd kan worden. Deze inzet wordt contractueel vastgelegd en krijgt een nadere, inhoudelijke invulling in de jaarlijks vast te stellen werkplannen. Vergoeding van de bijdragen van de betreffende huisartsen geschiedt via een, in principe vaste, aanstelling van de huisarts(en) bij de Rijksuniversiteit Limburg. Het grote voordeel van een dergelijke constructie is het gegeven dat de huisarts op deze manier officieel deel uitmakt van de facultaire en universitaire gemeenschap en een zekere rechispositie wordt gecreëerd. Met deze rechtspositie wordt niet alleen een gegarandeerd inkomen bedoeld, maar ook zaken als pensioenopbouw, ziekte-kostenverzekering en overige secundaire arbeidswoorwaarden. Ook de mogelijkheid tot actieve dan wel passieve (stemrecht) deelname aan de universitaire en facultaire bestuursorganen en daarmee de beinvloeding van het beleid wordt door een aanstelling gecreeerd.

Problematisch blifft het inkomensverschil tussen de gezondheidszorg (al dan niet in dienstverband) en de ambtelijke salarissen van de Rijksuniversiteit Limburg. Het nettosallaris bij, in het algemeen, kleinere aanstellingen (van 0.1 tot $0.3 \mathrm{Fte}$ ), blijkt vaak een teleurstellende ervaring voor de netwerk-huisarts.

Voor de universiteit kan deze financieringssystematiek nadelig zijn ondat sanctionering van achterblijvende prestaties ingewikkeld is bij een vaste rechtspositie. In de contracten dient dan ook opgenomen te worden op welke wijze de output beoordeeld kan worden en welke maatregelen genomen kunnen worden bij een structureel achterblijvende prestatie: Dit moet kunnen leiden tot beëindiging van het academiseringscontract inclusief de aanstelling bij de universiteit.

De hoogte van de aanstellingen varieert in hoge mate.

Figuur 3:5. illustreert de verschillen in aanstellingen per praktijk per 1 januari 1994; terwijl figuur 3.6 de verdeling van de aamstellingsfactoren van de individuele huisartsen presenteert.

\section{Figuur 3.5 Overzicht verdeling aanstellingsfactoren per praktijk van het HAM.}

12

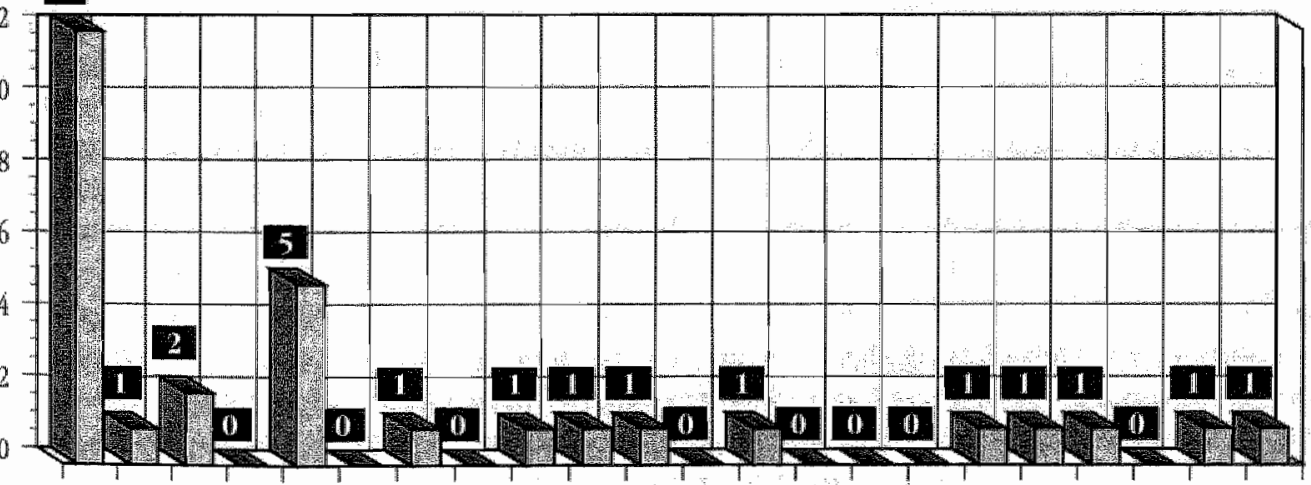

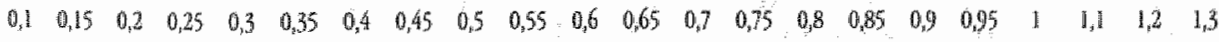

hoogte contract in fte's 
het gegeven dat ziektekostenverzekeraars vraagtekens zetten bij deze constructie. $Z$ ij ziju bezorgd dat er gezondheidszorgformatie aan de bestaande formatie wordt toegevoegd De ontrekking van formatie an de zorg, doordat de gevestigde huisants universitaire diensten levert, komt echter overeen met de door de huisarts-medewerker te leveren zorgomwang. Wel kan er sprake zijn van een probleem op het gebied van do "continuiteit van zorg". Diverse huisartsen leveren zorg aan dezelfde popullate, hetgeen op het gebied van overdracht van zorg en onderlinge communicatie hogere eisen stelt. Voorts leert de ervaring dat het geruime tijd duurt aborens de toegevoegde huisarts-medewerker het vertrouwen van een substantiele groep patiènten gewonnen heeft. Deze overwegingen spelen echter ook bij de introduktie van een nieuwe huisarts in de praktijk en betreffen dus niet speciaal de samenwerking met een uniwersiteit.

\subsubsection{Prestatie tegen geld}

Op papier is er veel te zeggen voor deze financieringssystematiek. Toch blijken er nadelen te zijn.

Allereerst is er geen sprake van onkostenvergoeding, zodat in economische zin fiscalc belastbaarheid aan de orde is. Dit geldt uiteraard ook bij het eerder beschreven model "prestatie tegen salaris", maar tegenover het fiscale nadeel staat in dat model het voordeel van rechtszekerheid, pensioenopbouw en andere secundaire voorwaarden. In het model "prestatie tegen geld" zijn deze voordelen niet aanwezig.

Van groter belang is het nadeel dat bij deze beloningsmethodiek de academische huisartsen geen directe mogelijkheid hebben beleidsmatig invloed wit te oefenen op de gang van zaken aan de universiteit, aangezien actief en passief stemrecht afwezig zijn. Dat is dan ook de reden waarom dit model slechts incidenteel en bij een zeer geringe bijdrage van de huisarts(praktijk) aan het netwerk, wordt toegepast.

\subsubsection{Outputfinanciering RNH}

Reeds langere tijd wordt geprobeerd een systeem van output-financiering in het HAM te introduceren, teneinde een meer rechtstreekse relatie tussen prestatie en beloning aan te brengen. Vanaf 1 januari 1994 wordt dit type financiening gedeeltelijk roegepast voor de taken op het gebied van het Registratienet Huisartipraktijken (RNH) 16,29,32. Het RNH heeft tot doel een steekproefkader voor wetenschappelijk huisartsgeneeskundig onderzoek op te bouwen. Daartoe is een groot aantal geacademiseerde huisartsen bereid gevonden op systematische en geautomatiseerde wijze een beperkte set van patiëntgegevens (inclusief probleemlijsten) te tegistreren en actueel te houden.

De huisartsen krijgen daarvoor een zogenaamde basisaanstelling van 0,05 Fte per registrerende huisarts, maar voor het overige wordt hun inspanning per jaar achteraf vergoed. Op basis van het antal correct geincludeerde patientgegevens wordt, aan de hand van het beschikbare budget, een tarief per patiënt berekend. Elke registrerende huisarts krijgt vervolgens tegen dit tarief voor de geleverde gegevens betaald.

Deze output-financiering word momenteel alleen voor de registratietaak toegepast. 


\subsubsection{Vergoeding van de exploitatiekosten}

Naast het honoreringsbestanddeel moeten uiteraard de exploitatiekosten als gevolg van de participatie aan onderwijs, onderzoek en registratie betaald worden. Door deelname aan het netwerk worden namelijk in de huisartspraktijk extra kosten gemaakt. Gedacht moet worden aan:

- huisvestingskosten (energie en water, onderhoud, schoonmaakkosten);

- bureau en huishoudelijke kosten (kantoormiddelen, drukwerk, telefoonkosten, porti, huishoudelijke uitgaven);

- extra personeelsinzet ten behoeve van secretarieel/administratieve ondersteuning:

- reis-en verblijfkosten.

In het HAM worden deze kosten op basis van een lumpsum-financiering aan de deelnemende praktijken vergoed. Per full-time equivalent (1.0 Fte) samenwerking werd. jaarlijks een bedrag van Fl. 20.000 = uitgekeerd ais onkostenvergoeding.

Vanaf 1 januari 1993 is dit bedrag verhoogd naar Fl. 22.000=.

Voor een jaarlijkse indexering van deze vergoeding is nog niet gekozen.

\subsubsection{Totaal jaarlijkse kosten HAM}

Samenvattend kan gezegd worden dat in het beschreven netwerk van 30 huisartspraktijken jaarlijks de volgende kosten worden gegenereerd:

Salariscomponent (prestatie tegen salaris)

Per jaar $6.95 \mathrm{Fte}^{*}$ gemiddeld salarisniveau (Fl. 100.000. $=$

Fl. $695.000 .=$

Salariscomponent (prestatie tegen prestatie)

Per jaar 3.1 Fte gemiddeld salarisnveau (FI. 100.000. $)=$

F1. $310.000 .=$

Vergoeding in geld (prestatie tegen geld)

FL. $60.000 .=$

Outputfinanciering Registratie

Per jaat 1.70 Fte

F1. $170.000 .=$

\section{Onkostencomponent}

Per jaar 9.6 Fte "lump-sum vergoeding (Fl. 22.000: $\Rightarrow$

F1. 211.200.

F1. 1.446.200. $=$ 


\subsection{Contracten en werkplannen}

\subsubsection{Inleiding}

Het HAM heeft vanaf de oorsprong gekozen voor een overeenkomst met de deelnemende huisartsen, enerzijds met behulp van een academiseringscontract, anderzijds met jaarlijks op te maken inhoudelijke werkplannen.

Het contract beschrift de samenwerking op hoofdlijnen en gaat niet gedetailleerd in op de inhoudelijke taakstelling. Daartoe wordt verwezen naar de inhoudelijke jaarwerkplannen.

\subsubsection{Contracten}

Alhoewel de contracten met de huisartspraktijken van het HAM op details van elkaar verschillen zijn er drie hoofdvormen te onderscheiden. Allereerst bestaat er een contract voor een samenwerking, waarbij vanuit de vakgroep huisartsgeneeskunde een (voltijds) huisarts naar de betreffende huisarts wordt gedetacheerd. In het HAM wordt dat, zoals eerder vermeld, een zogenaamde RL-arts genoend. Deze RL-arts neemt actief deel aan de gezondheidszorg-activiteiten in de praktijk en heeft eveneens een belangrijke rol op het gebied van onderwijs, onderzoek en registratie.

De tweede contract-vorm is met name toegepast bij de praktijken in de eerste fase, waarbij de deelname aan het HAM van grotere omvang was $(>0.4 \mathrm{Fte})$.

De derde contractvorm tenslotte is gebruikt bij samenwerkingsvormen van geringere omvang.

Alle contracten beschrijven de volgende onderwerpen:

\section{- begripsbepaling:}

een uitleg van de, in het kader van academisering, belangrijke begrippen

- openstelling praktijk:

de praktijk wordt opengesteld voor activiteiten op het gebied van onderwijs, onderzoek, registratie en gezondheidszorgontwilkkeling.

- er is een jaarlijkse verplichting een werkplan op te maken.

- vergoedingsregeling inzake exploitatiekosten en eventueel investeringen in bouw

- wat te doen bij een vertrek van éen van de gevestigde huisartsen wit de huisartspraktijk

- eventueel kan een regeling opgenomen worden waarin beschreven staat wat er dient te gebeuren bij ziekte of overlijden van de huisarts

- in de contracten is expliciet opgenomen dat er jaarlijks een evaluatie door de huisartspraktijk wordt ingediend

- indien de huisartsen volledig in dienst komen van de universiteit en de tijd die besteed wordt aan daadwerkelijke patiëntenzorg terugfinancieren, wordt een financieringsregeling gezondheidszorgtaken opgenomen

- geschillenregeling

- looptijd van het contract

De gebruikte drie contractvormen zijn in appendix B volledig beschreven. 


\subsubsection{Werkplannen}

De werkplannen gevern een gedetailleerde, inhoudelijke beschrijwing van de participatie van de praktijk aan het netwerk.

De voorbereiding van de werkplannen geschiedt door de portefeuillehouder academisering en de beheerder, namens het bestuur wan de vakgroep huisartsgeneeskunde In toenemende mate wordt in dit verband een bijdrage verwacht van het Dagelijks Bestuur Academisering.

Alle aan het netwerk participerende huisartspraktijken worden jaarlijks in november december gevisiteerd ten einde het werkplan voor het daarop volgende jaar te kunnen vaststellen.

Uiteraard gelden bij de vaststelling van de werkplannen een aantal randvoorwaarden:

1

Met het bestuur van de faculteit der geneeskunde is overeengekomen dat 3.0 Fte ingezet moet worden ten behoeve van het onderwijs in het basiscurriculum. In principe dient het HAM garant te staan voor de opleiding van:

- 22 studenten PMOH (Praktisch Medisch Onderwijs in de huisartspraktijk ofwel het 5 e jaars co-schap huisartsgeneeskunde) ${ }^{30}$

- 60 studenten ten behoeve van het Adoptieprogramma ${ }^{31}$, waarbij studenten in de studiejaren 2, 3 en 4 door een huisarts "geadopteerd" worden om daar, gekoppeld aan het thematische blokonderwijs, bepaalde activiteiten te verrichten.

- 70 studenten voor het eerste-jaars programma Oriëntatie Eerste Lijn (OEL), een kennismakingsstage in de huisartsgeneeskunde voor 1e-jaarsstudenten.

\section{2}

De overige formatie (6.6 Fte) is in principe beschikbaar voor onderzoek en registratieactiviteiten.

3

De HAM-praktijken gefinancierd uit de Stimuleringsnegeling Universitaire Huisartspraktijken mogen uitsluitend ingezet worden in het kader van de huisartsopleiding en binnen de, in de ministeriële regeling geformuleerde, randvoorwaarden.

De in het werkplan opgenomen activiteiten mogen qua omvang de contractueel vastgellegde inzet uiteraard niet overstijgen.

De afgesioten werkplannen worden ter informatie aan het bestuur van de Faculteit der Geneeskunde voorgelegd.

Ter illustratie wordt in Appendix C een beschrijving van een werkplan gegeven.

\subsection{Aansturing van processen in het HAM}

In deze paragraaf wordt, vooruitlopend op de bedriffsorganisatorische onderbouwing in hoofdstuk 5 , inzicht verschaft in de wijze waarop de gewenste eindresultaten modelmatig worden gestuurd. 
Het HAM moet gezien worden als een netwerk, gebaseerd op interorganisationele samenwerking thissen de vakgroep huisartsgeneeskunde van de Rijksuniversiteit Limburg enerzijds en een aantal huisarsen uit de regio Limburg $/ 2.0$ Brabant anderzijls. Beide partijen in het netwerk hebben eigen doelstellingen, die slechts gedeeltelijk op elkaar aansluiten. De huisarts heeft als primaire doelstelling het leveren wan adequate patiêntenzorg, terwijl de universitaire vakgroep huisartsgeneeskunde hel geven van onderwijs en het verrichten van onderzoek nastreef. Door wederzijdse beinvloeding bijwoorbeeld in het kader van een netwerk kunnen beide partien met behulp van elkaar de geformuleerde eigen doelstellingen beter realiserem.

Als algemene doelstellingen van het netwerk kunnen worden gefomuleerd:

- Uirwoering en verdere ontwikkeling wan het universitair onderwijs aan de Faculteit der Geneeskunde in het algemeen en van het praktisch medisch onderwijs in de huisartsgeneeskunde in het bijzonder;

- Uitvoering en verdere ontwikkeling van de opleiding tot huisarts;

- Uitvoering van wetenschappelijk onderzok (op het gebied van technology assessment/interventie-onderzoek, kwaliteitsbewaking, onderzoek van onderwijs, verou= dering/thuiszorg, voeding en health promotion (preventie en gvo);

- Verbetering van patiëntenzorg enerzijds door de (in)directe beinvloeding vanuit het wetenschappelijk onderwijs en onderzoek, en anderzijds door de ontwikkeling van innoverende zorgprojecten;

- Beschikbaarheid van een werkplaats voor huisarts docenten en huisarts-onderzoekers ten einde de ervaring met de huisartsgeneeskundige zorg bij te houden en aan te scherpen.

De verantwoordelijk hoogleraar en de beheerder van de vakgroep Huisartsgeneeskunde, daartoe gemandateerd door het bestuur van de vakgroep, en de uitvoerenden (de geacademiseerde huisartsen in het netwerk) formuleren gezamenlijk de in een bepaalde planperiode te bereiken relevante eindtoestand van een aantal bedriffsprocessen. Steeds meer neemt het Dagelijks. Bestuur Academisering, waarin de geacademiseerde huisartsen vertegenwoordigd zinn, de rol van de hoogleraar/beheercler ower hetgeen een wenselijke ontwikkeling wordt geacht.

In het overleg tussen vakgroep en academische praktijk worden de wederzijdse verantwoordelijklieidsterreinen afgebakend, enerzijds in termen van beschikbaar te stel: len middelen en informatie, anderzijds in termen van beoogde resultaten (management by objectives).

Met de uitvoemenden worden echter niet alleen de doelen en het middelenkader voor de betreffende planperiode vastgelegd, maar wordt ook geprobeerd een aantal (kwantitatieve) "regelgrenzen" vast te stellen.

Formulering van de afspraken omtrent informatie en middelen (input) en de beoogde resultaten en regelgrenzen (output) vindt in het Huisartsgeneeskundig Academiseringsnetwerk Maastricht plaats door middel van twee documenten. Enerzijds is met de geacademiseerde huisartsen een academiseringscontract gesloten. In dit contract wordt voor de inhoudelijke zaken verwezen nar een nader op te maken werkplan. Het werkplan wordt per praktijk jaarlijks vastgesteld op basis van een overleg tussen (een delegatie van) het dagelijks bestuur academisering en (een delegatie van) de geacademiscerde praktijk.

Het contract en het werkplan voorzien de uitvoerenden van de noodzakelijke informatie over het middelenkader en de na te streven doelen. 
Vervolgens vindt de uitvoering van de activiteiten plaats. Deze uitvoering geschiedt tijdens de planperiode (van 1 jaar) wrij zelfstandig; voortgangscontrole en eventuele. bijsturing geschieden primair door de uitvoerenden (de professionals) zelf. Uiteraard is er per deelactiviteit regelmatig bilateraal overleg. Voor de onderwijsactiviteiten tus: sen de verantwoordelijke coördinatoren van de vakgroep en de huisarts, voor onderzoek tussen de projectuerantwoordelijke hoofdonderzoeker en de geacademiseerde praktijk en voor de registratie-activiteiten van het RNH (Registratienetwerk Huisartspraktijken $)^{16,29,32}$ tussen de coördinator van het RNH en de praktijk(en).

Aan het einde van de planperiode worden de resultaten en het totale proces door de beide partijen gezamenlijk geèvalueerd en getoetst aan de geformuleerde werkplannen. Deze evaluatie en toetsing leiden vervolgens tot een hernieuwd overleg tussen de coördinerend leider (hoogleraar academisering en beheerder, namens het bestuur) en de uitvoerenden. Dit overleg moet leiden tot de formulering van het werkplan voor de volgende planperiode.

Over de vaststelling van de beoogde resultaten en de beschrijving van de (kwantitatieve) regelgrenzen het volgende. Het blijkt op sommige punten ingewikkeld te koment tot een werkbare formulering van de resultaten en regelgrenzen. Ten aanzien van onderwijsactiviteiten kunnen de afspraken vrij goed gemaakt worden; het gaat doorgatans over aantallen op te leiden studenten, of het leveren van materiaal (toetsvragen of casuistiek) ten behoeve van het onderwijs in het basiscurriculum of de huisartsopleiding. Ook bij de registratie-activiteiten ten behoeve van de opbouw van een geanonimiseerd steekproefikader van huisartsgeneeskundige gezondheidsproblemen blijkt de vaststelling van output relatief eenvoudig. De uitvoerder weet precies welke patiënt-variabelen moeten worden geregistreerd en binnen welk tijdsbestek. Richtgetallen ten aanzien van de beoogde output per planperiode worden met de praktifken systematisch besproken.

Voor de participatie aan onderzoek is de definitie van resultaat en regelgrens vaak moeilijker. Als het gaat om het includeren van specifieke patiënten-categorieën in het onderzoeksproject kunnen de regelgrenzen nog vastgesteld worden, maar indien de onderzoeks-taakstelling van de uitvoerende een andere is, wordt de definitie wan het resultaat moeilijker.

Om een voorbeeld te geven:

Als de geacademiseerde huisarts belast is met de formulering van een nieuw onderzoeksproject of de nadere uitwerking van een hypothese, kan alleen worden vastgesteld binnen welk tijdsbestek de huisarts deze activiteit moet afronden. Nadere regelgrenzen zijn nauwelijks te geven.

Eenzelfde moeilijkheid bestaat bij de inschakeling van de geacademiseerde huisartsen bij de ontwikkeling van onderwijs-experimenten (nieuwe keuze-onderwijs programma's, onderwijsprogramma's voor de huisartsopleiding en dergelijke).

Aan een aantal voorwaarden voor optimale aansturing van de gewenste output wordt voldaan:

- overeenstemming tussen de leiding en de uitvoerders over de doelstellingen wordt bereikt via de jaarlijkse formulering van het inhouclelijke werkplan;

- aanwezigheid van een "overeenkomst" inzake de uitvoering van de taken voordat de uitvoering gaat plaatsvinden, is gerealiseerd via de academiseringscontracten; 
- Loetsing aan het einde van elke planperiode van het resultat in relatie tot de gedefnieerde doelen vindt structureel jaarlijks plaats;

- aan de hand van deze toetsing, wordt een nieurw (eventueel bijgesteld) werkplan voor de nieuwe planperiode geformuleerd en vastgesteld;

- de voortgangscontrole op de uitvoering en de bijsturing van de uitwoering worden tijdens de planperiode primair door de uitvoerenden zelf verzorgd, waarbij slechts bilateraal owerleg plaatsvindt tussen docentonderzoeker enerzijds en de geacademiseerde huisarts anderzijds.

Het totale netwerk wordt uiteraard beüvloed door processen van buitenal, de zogenaamde macro-omgeving. Deze macro-omgeving bestaat uit diverse instellingen, instanties zoals de ministeries van Onderwijs, Cultuur en Wetenschappen (OCW) en Welzijn; Volksgezondheid en Sport (WVS), de ziektenkostenverzekeratrs, de universitaire en facultaire besturen, de Landelijke Huisartsvereniging (LFV) en de Districts Huisartsvereniging (DHV), het Nederlands Huisarts Genootschap (NHG), subsidiegevers en uiteraard ook de patiënten. Veranderingen vanuit de macro-omgeving kunnen effect hebben op het academiseringsnetwerk. Om hierop te anticiperen wordt vanuit het Huisartsgeneeskundig Academiseringsnetwerk Maastricht (HAM) periodiek een strucrureel overleg gevoerd met sommige instanties uit deze macromomgeving. Daartoe behoort een gesprek met het bestuur van de Faculteit der Geneeskunde; waarin de voortgang van de academisering besproken wordt, witeraard in rellatie tot de door de faculteit beschikbaar gestelde middelen. Ook is er een structureel overleg met de DHV. Met de overige partijen in de macro-omgeving is er vanuit het netwerk geen structurele overlegsituatie gecreeerd. Wel zijn er op basis van concrete plannen en voorstellen bilaterale contacten. Een overzicht van de beoogde sturingsprocessen in het HAM wordt in schema 3.7 gegeven.

\section{Figuur 3.7 Beoogd sturingsmodel academisering huisartsgeneeskunde (HAM)}

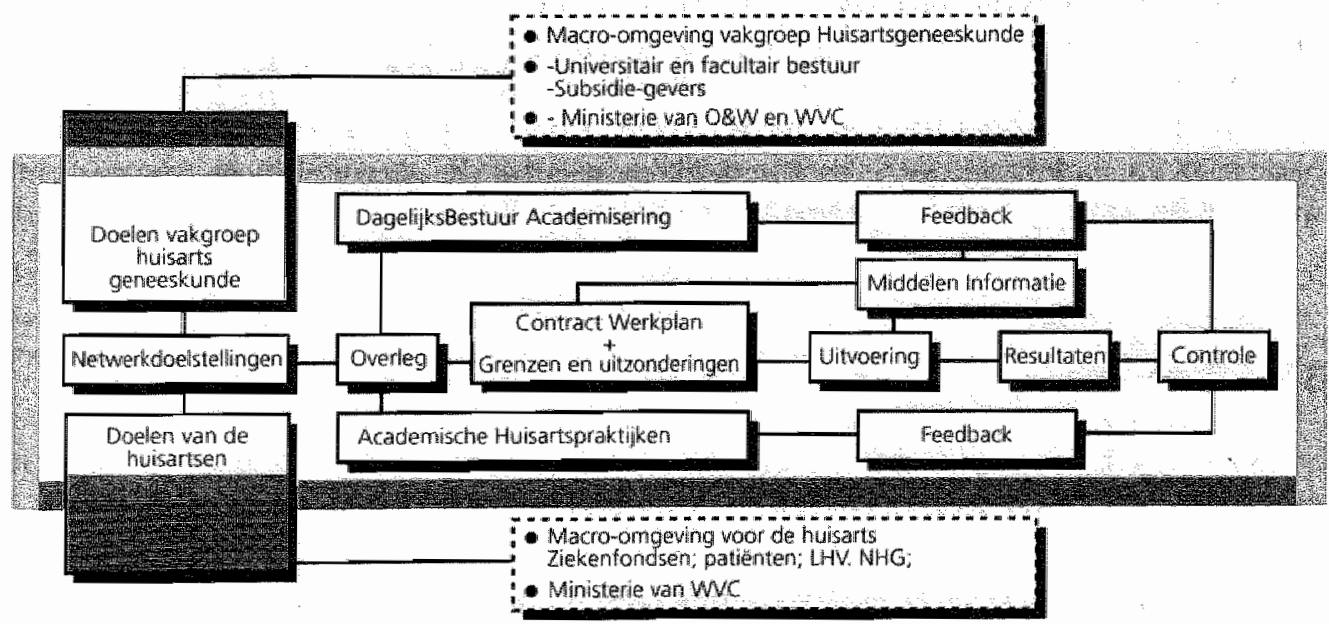




\subsection{Evaluatie}

Het Huisartsgeneeskundig Academiseringsnetwerk Maastricht, bestaande uit 30 huisantssettings met herin 83 werkzame huisartsen werd in dit hoofdstuk beschreven. De wijze waarop de samenwerking tussen de universiteit en deze huisartsen tot stand kwam komt daabil aan de onde, evenals contractuele en financiele aspecten. Her geintroduceerde systeen van langcurige contracten en jaar-werkplannen blijkt goed te functioneren. Sturing door beide partijen wordt hierdoor gefaciliteerd.

Hoofdstuk 4 introduceert een model voor de werving van zogenaamde affiliatic-praktijken. Toepassing van een dergelijk modal, gecombineerd met voldoende aandacht woor de oordelen van huisartsen over hun deelname aan wetenschappelijk onderzoek, zal kunnen leiden tot een professionelere benadering wan het huisartsgeneeskundig veld. De betrokkenheid van de hutsartsen zal er door toenemen, hetgeen de kwaliteit van de onderzoeksresulaten in positieve zin kan beinvlceden.

De verwachting bestaat dat de verschillende modellen en de concrete uitwerking goed toepasbaar zijn, ook in andere universitaire regio's. Het ontwikkelen van academisering in de huisartsgeneeskunde volgens de netwerk-concepten wordt reeds langere tijd gezien als het meest in anmerking komende model. Dit blijkt onder andere uit de diverse rapportages van de Begeleidingscommissie Academisering Eerstelijns Gezondheidsworg (BAEG)24-28. Bedoeling van de BAEG is de academisering van de huisartsgeneeskunde in Nederland als geheel aandacht te geven en te laten plaatsvinden volgens vergelijkbare concepten. Om zicht te krijgen op de bestaande mogelijkheden en knelpunten is een nationale enquête gehouden. Hoofdstuk 6 beschrijft de belangrijhsté uitkomsten van deze enquête.

Een vergelijkbare studie is uitgevoerd om het proces, de inhoud en de uitkomst van het HAM van de Rijksuniversiteit Limburg te beschrijven. De resultaten van deze studie worden in hoofdstuk 7 beschreven. De hoofdstukken 3,5,6 en 7 kunnen dan ook gezien worden als de hoofdstukken die het meest direct samenhangen met de academiseringsconcepten en -processen. De hoofdstukken 4,8 en 9 gaan dieper in op de samenwerking tussen universiteiten en huisartsen in de vorm van affiliatie. Hoofdstuk 8 geef inzicht in het oordeel van huisartsen over deelname aan wetenschappelijk onderzok, terwil hoofdstuk 9 dieper ingaat op de planning en coordinatie van onderwijs en onderzoek in huisartspraktijken, waarbij de centrale vraag beantwoord wordt of huisartsen vooraf opgegeven vootkeuren volgen.

\subsection{Literatuur}

1

Masisflosole van de Rjiksuniwersitent Limburg. Maastricht: Rijksuniversiteit Limburg, 1972

2

Nota Academisering in de Eerstelijn. Maastricht: Faculteit der Geneeskunde, Rijksuniversiteit Limburg, 1982

3

Rapport van de Commissie Academisering Eerstelijnsgezondheidszorg en Ambulante Geestelijke

Gezondheidszorg in Limburg. Matastricht: Rijksuniversiteit Limburg, 1983 
Beusmans GHMI et all. Medische Faculteit Maastrich en eerste liph standpuntbepaling besturin PHV Mastricht. Med Contact 1981; 15: 437-441

5 Integraal plan voor universitaire participatie in de regionale gezondheidszorg Masstricht: Rijksuniversiteit Limbuirg, 1982

6

Crebolder HFJM, Kocken RJI. Academisening van huisartspraktijken. The Practitioner (Ned uitgave) 1989; 15:1130.2 7

Crebolder HFJM. Te leer in de eerste lijn; inaugurale rede, Maastricht: Faculteit der Geneeskunde, Rijksuniversiteir Limburg, 1987

8

Blanken AJ, Oudkerk RH. Samen werkt het beter: een onderzoek natar de samenwerking tussen universiteir en huisatsen. Groningen: Faculteit Bedrijfskunde, Rijksuniversiteit Groningen, 1988

9

Keuning D, Eppink Df. Management en organisatie: Theorie en toepassing. H.E. Stenfert Kroese BV. Leiden/Antwerpen, 1985

1.0

Wassenberg A. Netwerken: organisatie en strategie. Boom Meppel. Amsterdam, 1960

j1

Schieman CJ. Beheersing valn bedrijfsprocessen. H.E. Stenfert Kroese. Leiden, 1975

12

Keuning D, Eppink DJ. Management en organisatie: Theorie en toepassing. H.E. Stenfert Kroese BV. Leiden/Antwerpen, 1985

13

Borter $\mathrm{CH}$. Industrie en onganisatie; een verkenningstocht. Kluwer/NIVE, 1970

14

Douma S, Schreuder H. Economic approaches to organizations. Prentice Hall International Lud. United Kingdom, 1992

15

Scapens RW. Management Accounting: A review of recent developments. McMllan Education Ltdl. United Kingdom, 1987

16

Metsemakers JFM, Höppener P, Knottnerus IA, Kocken RJ, Limonard CBG. Computerized health informa* tion in the Netherlands: a registration network of family practices. Brit J Gen Pract 1992,62:102-6

17

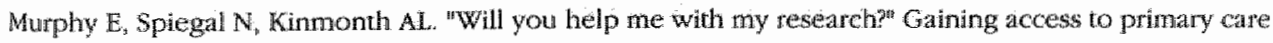
settings and subjects. Br four of General practice 1992; 42 : 162-5

18

Silagy $\mathrm{CA}$, Carson NE. Factors inflecting the level of interest and activity in primary care research among general practitioners. Fam Pract 1989; 6: 173-6 
Borgiel AFM. Dunn EV, Lamont CT, et at. Recruiting family physicians as participants in research Fam Pract 1989: 6: $168-72$

20

Herber Co: Why family practice tesearchi Canadian Family Physician 1991; 37: 335-8

21

Gagnon PA, stsak LE, Gouler FE. Gething stanted in family research (part 1). Canadian Family Physician $1991 ; 37: 596-601$

22

Gagnon A, Susak LE, Gouhe FE. Getting started in family research (part 2). Canadian Family Physician $1991 ; 37: 850-4$

23

Booth C. Research and the fencal practitioner. Br Med I 1987; 295: 1614-9

24

Frojectgroep Bwaluatie TSR. Academisering in de praktijik. Tutssentijdse rapportage van de projectgroep Evaluatie wan de Tijdelike Stmuleringsregeling Universitive Huisartspraktifken. Amsterdam: Instituut woot Huisartsgeneeshunde, 1990

25

Projectgroep Evaluatie TSR. Acadenisering in de praktijk. Academisering in een netwerk. Verslag van een wragenlijstonderzoek. Amsterdami Institutut woor Huisartsgeneeskunde, 1990

26

Projectgroep Evaluatie TSR. Academisering in de praktijk. Academisering in zicht. Visies op de doelstellingen woor een netwerk. Ansterdam: Instituut voor Huisartsgeneeskunde, 1990

27

Projectgroep Evaluate TSR. Academiserng in de thuisartspaktijk. Eindrapport van de projectgroep Evaluatle van de Tijdelijke Stinuleringsregeling Universitaire Huisantsprakijlken. Amsterdanu: Instirutut voor Hussartsgeneeskunde, 1990

26

Begeleichngsconmissie Academüseng Eerstelinns Geneeskunde. Ontwikkelingsplan academisering huisartsgeneeskunde BABG 150, 1991

29

'Registraticnet Huisartspraktijken; gezondheidsproblemen en diagnoses in de huisartspraktijk' (Riksuniversiteit Limburg, Jargang 5, nummer 1, maart 1993)

30

Mantens FMJO, Opt Root JMH. Practical Medical Education in General Practice. Med Education 1992; 26: 213-7

31

Metsemakers JFM, Crebolder HFJM et al. Het adoptiemodel als een vorm wan praktisch medisch onderwijs. Gezond Onderwhigs \. Bohn, Stafleu van Loghum, Houten/Zeventen 1992

32.

Metsemakers JFM. Unlocking patientis records in general practice for research, medical education and quality atssurance: the Registration Network Family Practices. Proefschrif. Maastricht: Rijksumiversiteit Limburg, 1994 
Groot ILCM. Management van universileiten; een onderzoek natr de mogelijkeden voor doethatig en doeltreffend universicair bestuur. Wolters Noordhofr. Groningen, 1988

34

Huygen FJA, Jenkins $C D$, Kolk $F$, Pedersen PA. Report of the evaluation committee on the innovation fund for extramural activities of the Faculty of Medicine / University Limburg. Maastricht, 1990

35

Knotnerus IA. Dialectiek van het onderzoek in de huisartsgeneeskunde; inaugurale rede, Maastricht: Faculteir der Geneeskunde, Rijksuniversiteit Limburg, 1988 


\section{HOOFDSTUK 4}

\section{MODELBESCHRIJVING YOOR}

\section{DE BENADERING VAN EN DE SAMEN-}

WERKING MET AFFILIATIE-PRAKTIJKEN

\subsection{Inleiding}

In het kader van de behoefte aan samenwerking tussen universiteit en huisartsgeneeskundig veld is het nuttig en nodig planmatig en systematisch te werken aan de ontwikkeling en het onderhoud van samenwerkingsrelaties met praktizerende huisartsen ter ondersteuning van het huisartsgeneeskundig onderwijs- en onderzoekprogramma. De aanpak en ervaring aan de Rijksuniversiteit Limburg kan van betekenis zijn voor andere instellingen. Aan deze instelling bestaat behoefte aan participatie van meer huisartsen, dan beschikbaar via het academiseringsnetwerk en het is te verwachten dat dit een algemeen verschijnsel zal zijn. Er is een grote behoefte aan inbreng van huisartsen die doorgaans aan éen of slechts enkele projecten en voor de duur van het specifieke project (meestal minder dan 3 jaar) participeren. In het hier gepresenteerde model worden dit de zogenaamde "affiliatie-praktijken" genoemd.

Regelmatig moet er door de projectleiding geworven worden onder de huisartsen, meestal in de universitaire regio Limburg en Zuid-Oost Brabant.

Voor de onderwijsprojecten in het basiscurriculum van de geneeskundige faculteit geschiedt de werving in de regel jaarlijks, terwijl voor de huisartsopleiding regelmatig en voor elk onderzoeksproject apart huisartsen worden benaderd.

De gekozen wervingsstrategie is wisselend, al heeft de komst van een centraal coördinatiepunt in de vorm van het zogenaamde Coördinatiebureau Eerste Lijn (CEL) van de Rijksuniversiteit Limburg gezorgd voor nadere structurering van deze strategie. Vanwege het lokale karakter van het CEL is besloten een uitvoerige beschrijving van dit centrale coördinatiepunt niet in dit hoofdstuk op te nemen. We kunnen ons echter voorstellen dat juist het onderwerp van de coördinatie van onderwijs en onderzoek met huisartsen bij andere universiteiten in de belangstelling staat. Derhalve is in Appendix D een beschrijving van de opzet, werkwijze en de verantwoording van het CEL opgenomen.

Het in dit hoofdstuk gepresenteerde model voor de benadering van en de samenwerking met affiliatie-praktijken is tot stand gekomen op basis van de ervaringen van de vakgroep huisartsgeneeskunde van de Rijksuniversiteit Limburg alsmede aan de hand van de bestudeerde en in hoofdstuk 2 beschreven literatuur. ${ }^{11 / m} 8$ 


\subsection{Werving van affiliatie-praktijken voor onderwijs en onderzoek; een gefaseerd model}

De in hoofdstuk 2 beschreven literatuur ${ }^{1-8}$ geeft aanknopingspunten voor de ontwil keling van een model voor de werving van de zogenaamde aftiliatie-praktijken.

Het hier gepresenteerde model wordt gerelateerd alan deze literatur en is in de loo wan de tijd aangepast naar aanleiding van de eigen ervaringen.

In het model worden vijf fasen onderscheiden:

1 Voorbereiding

2 Acceptatie

3 Werving

4 Uitvoering

5 Nazorg

\subsubsection{De voorbereidingsfase}

De eerste fase betreft de voorbereiding van een onderwijs- of onderzoekprojec Naast het genereren en ontwikkelen van de onderzoekswraag of de doelstelling val het onderwijsproject en het bestuderen van de literatur moet er uitgebreide aandad worden besteed aan het "clesign" wan het project. Reeds in deze fase moeten de asper ten uitvoetbaarheid, tijdsinvestering en financiering van de bijdrage van de geaffilieer de huisartsen uitvoerig aandach krijgen. Dat kan door een praktizerende huisant vroegtijdig te betrekken bij de beschrijving wan het definitieve projectvoorstel. In di voorgestelde begroting moeten vergoedingen voor de deelnemende huisartsen en doktersassistenten worden opgenomen. Alhoewel het vaak ingewikkeld is de noodza kelijke inspanningen van de huisartsen en de assistenten te kwantificeren, is dezi exercitie van groot belang voor de uiteindelijke uitvoering wan het project. Een eerst inventarisatie van de mogelijke belangstelling bij huisartsen en de beschikbaarheic wan voldoende tijd kan worden uitgevoerd. Aangezien het nog lang niet zeker is dat het project daadwerkelijk uikgevoerd zal gan worden mogen geen valse verwachtin. gen gewekt worden en vooval geen toezeggingen worden gedaan.

\subsubsection{De acceptatiefase}

Tijdens deze fase wordt aandacht besteed aan de acceptatie van het projectvoorstel op: diverse punten.

\section{De inboudelijke acceptatie}

Universilaire projecten moeten een voldoende inhoudelijk draagvlak krijgen, alvorens ten uitvoering te kunnen worden gebracht. Na de voorbereiding door de projectgroep kan verdere inhoudelijke verdleping gezocht worden door discussies in de verantwoordelijke vakgroep. Het is aan te bevelen, zeker bij beoogde grootschalige onderwijsprojecten, reeds in de acceptatiefase contact te zoeken met huisartsen-organisaties (districts huisartsverenigingen, huisartsgroepen in de betreffende regio's). 


\section{De eibusche acceptatie}

Wak bevatten projecten op huisartsgeneeskundig terrein medisch-ethische aspecten, die beoordeeld dienen te worden door een medisch-ethische commissie.

\section{De financiele acceptatie}

Onafhankelijk van welke subsidiegever financiele ondersteuning wordt gevraagd, is het van groot belang de financiële consequenties wan de witvoering van het project goed in kaat te brengen en met de beoogde subsidiegever te bespreken. Bij de meeste onderwijsprojecten zal de onderwijsinstelling (de unversiteit) zelf de financier zilj, hetgeen betekent dat het bestuur van de instelling overtuigd moet worden van de noodzaak wan het project. In tijden van een afnemend middelenkader wordt het steeds ingewikkelder voor specifieke onderwijsprojecten adequate financiering te vinden. Voor onderzoekprojecten zijn de mogelijkheden ook beperkt, maar zijn er regelmatig externe geldbronnen aan te boren, zowel in termen van subsidie onderzoek (de. universiteit vraagt een projectinanciering aan bij een subsidiegever) als contractonderzoek (een derde vraggt een concreet onderzoek bij de universiteit aan en is bereid dit te financieren).

\subsubsection{De wervingsfase}

In deze fase wordt aandacht besteed aan de werving van aan het project deelmenende

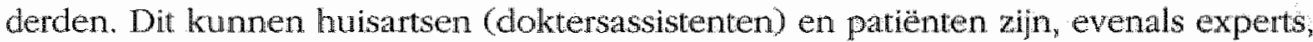
noodzakelijk voor de bezetting van project- en begeleidingsgroepen. Deze laatste categorie is meestal reeds in de voorbereidingsfase bij het project betrokken. Voor de bespreking van deze fase beperken wij ons tor de werving van de huisartsen en de patienten.

Nog steeds vinden er grootschalige wervingsakties plaats zonder een overwogen strategie. Uit lokale ervaringen blijkt dat huisartsen behoefte hebben an benadering door de universiteit vanuit één herkenbaar en erkend coördinatiepunt (dit kan de vakgroep huisartsgeneeskunde zijn of een apart ingesteld coördinatiepunt). Aan de Riksuniversiteit Limburg is gekozen voor de ontwikkeling van een zogenaand Coördinatiebureau Eerste Lijn (het CEL). Indien een faculteit coördinatie van alle activiteiten met huisart sen beoogt, lijkt het verstandig een dergelijk coördinatiepunt te organiseren op een centralle en onafhankelijke plaats in de organisatie wan de faculteit. Ook andere extramurale en intramurale vakgroepen zullen gebruik willen (moeten) maken van de coördinatiefaciliteit en zullen dat sneller doen indien dit via een onafhankelijke interne instantie gebeurt.

Via é̉n centraal coördinatiepunt kan de interesse van de huisatsen in de specifieke regio worden geinventariseerd. In hoofdstuk 9 worden de resultaten van een onder zoek op dit gebied gepresenteerd. Dit onderzoek ondersteunt de gedachte dat planning en coördinatie van onderwijs en onderzoek mogelijk is via een gestratificeerde benadering wan het huisartsgeneeskundige veld. Stratificatie op basis van de voorkeuren van de huisartsen dient dan via een voormeting te geschieden.

Uitgaande van een centraal coördinatiepunt en de anwezigheid van inzicht in de mate waarin en de wijze waarop huisartsen alan her onderwijs en onderzoek willen en kunnen deelnemen zijn de volgende strategische momenten van belang: 


\section{* De rol van de "Stakeholders" en de "Local Champions"}

Zijn er "Stakeholders" en "local champions"3,5,6 die bij de werving van huisartsen invloed kunnen uitoefenen. Stakeholders zijn in dit verband personen of instanties die een bepaald belang kunnen hebben bij de uitwoering van het project. Indien stakeholders niet bij het project worden betrokken, kan een belangrijke belemmering ontstaan.

Local champions daarentegen dienen bij het project betrokken te worden vanuit een meer positief denkbeeld. De local champion is iemand die in een specifieke regio of op het te onderzoeken huisartsgeneeskundige terrein aanzien heef. Zowel de stakeholder als de local champion kunnen een essentiele rol spelen in de promotie van het project.

\section{* De centrale contactpersoon in de praktijk (de "gatekeepers")}

In de regel zal één van de huisartsen in de praktijk de "gatekeeper" zijn, van waaruit de onderzoeker de praktikmedewerking kan realiseren. Met de ontwikkeling van grotere huisartsgeneeskundige eenheden (gezondheidscentra, groepspraktijken) en de introductie van de functie van directeur in vooral gezondheidscentra, is her vaak verstandig ook de directeur bij de eerste introductie wan het project te betrekken. Voot benadering van grotere regio's kan in eerste instantie gekozen worden voor een introductie van het project in de huisarts(waarneem)groepen. In een dergelijke strategie zal vrij snel na de introductie wan het project in de huisartsgroep verdere detaillering van de informatie over het project moeten plaatsvinden in een gesprek met de centrale personen in de praktijk zelf. Aandacht voor de rol van de doktersassistent is zeer belangrijk, aangezien de ervaring leert dat een grote betrokkenheid van de doktersassistent leidt tot een toename van de compliance.

\section{* De wijze waarop de werving moet plaatsvinden}

$\mathrm{Na}$ definiëring van de stakeholders, de local champions en de gatekeepers dient de projectleiding vast te stellen op welke wijze de gewenste informatie-overdracht naar de huisartsen zal moeten plaatsvinden. Afhankelijk van het aantal noodzakelijke huisartsparticipanten kan gekozen worden voor een brede benadering van de gehele regio (al dan niet via een nieuwsbrief van het centrale coördinatiepunt) of een meer gerichte, gestratifceerde benadering. De eerste benadering van de huisarts kan schriftelijk plaatsvinden, gevolgd door een informatieve bijeenkomst in de huisartsgroep of de individuele huisartspraktifk, of in de vorm van een algemene informatie-avond. Het kan, vooral bij kleinere projecten, echter ook de voorkeur verdienen de huisartsen direct persoonlijk te benaderen. Het via advertenties benaderen van patientengroepen kent grote nadelen. De onderzoeker dient zich te realiseren dat rechtstreekse benadering van patiënten de betrokkenheid van de zorgverlener kan verzwakken in plaats van verstevigen. Patienten zijn in het algemeen bereid positief te reageren op adver tenties voor participatie aan onderzoek, maar de onderzoeker moet erop bedacht zijn dat elke oproep via de media automatisch zal leiden tot extra vragen aan de huisarts. Het verdient dan ook de voorkeur de huisarts indien mogelijk a priori te betrekken bij het project en met medewerking van de verantwoordelijke huisarts de patiéntenpopulative te benaderen. Dit verkleint bovendien de kans op de specifieke selectiebias die kan samenhangen met zelfselectie via de media.

De persoonlijke benadering heeft een meerwaarde boven de uitsluitend telefonische of schriftelijke. In elke werwingsstrategie zou daarom plaats moeten zijn voor op zijn minst één persoonlijk contact met de huisarts (en doktersassistent). 


\section{- De adequate informatie}

Uit national en internationaal onderzoek ${ }^{1-9}$ blijkt dat in de wervingsfase de volgende onderwerpen aandacht moeten krijgen:

- de inhoud, opzet en het doel van het project

- de belasting van het project voor de huisarts (wat wordt precies van de huisarts verwacht en welke tijd zal dat per patiënt extra betekenen)

de belasting van het project voor andere praktijkmedewerkers (doktersassistenc)

de belasting van het project voor de patiënten

- de steun die de huisarts vanuit het project kan krijgen

de vergoeding van specifieke onkosten

de honorering van de inzet door de huisarts/doktersassistent

de eventuele vergoeding van de patièten (reiskosten, bijzondere inspanningen)

de waardering van de bijdrage van de deelnemende huisarts in immateriele zin (vermelding in eindrapportage, proefschrift, co-auteurschap en dergelijke)

- de bekendmaking van de resultaten van het project aan de participanten.

Onvolledige voorlichting in de wervingsfase zal op de korte termijn wellicht leiden tot participatie van de praktijk aan het project, maar op de lange duur - bijvoorbeeld als blijkt dat de belasting veel groter is - zal de compliance hieronder te lijden hebben. Het is beter betrokkenheid te realiseren op grond van adequate informatie dan premature toezeggingen te doen, die uiteindelijk lleiden tot uitval van participanten. Men moet derhalve niet te snel tevreden zijn met een uitgesproken "ja-woord" van de huisarts. Het is verstandig reeds in de wervingsfase een gevoel wan collectiviteit tussen de onderzoeker en de huisartsparticipant te realiseren.

Het is te overwegen de wederzijdse afspraken vast te leggen in een contract, waarbij zowel de inhoudelijke als de financiële aspecten duidelijk beschreven worden. Beide partijen weten dan exact wat er van hen verwacht wordt.

\subsubsection{De uitvoeringsfase}

Tijdens de uitvoeringsfase van het project is het van groot belang met een zelkere regelmaat de praktijk persoonlijk te bezoeken. Met bezoeken van de praktijk door de onderzoeker kan aanleiding geven tot bespreking wan onduidelijkheden in het project, maar heeft ook een motiverende werking. Een periodieke telefonische benadering van de praktijken is vaak nict voldoende, zodat geadviseerd wordt de praktijken regelmatig te bezoeken. De frequentie hiervan kan per onderwerp verschillen.

Ook het genereren van voortgangsinformatie (eerste ervaringen, deelnemersaantallen, perspectieven, aanvullende afspraken) bijvoorbeeld in de vorm van een projectbulletin of nieuwsbrief kan tijdens de uitvoeringsfase van belang zijn de motivatie en betrokkenheid op het gewenste niveau te houden.

\subsubsection{De nazorgfase}

Vak wordt vergeten ook in de periode na de data-verzameling of na volledige beéindiging van het project de noodzakelijke nazorg in de richting van de participanten te realiseren. Vormen wan nazorg kunnen zijn:

- een laatste bezoek aan de praktijk, waarin evaluatief naar de uitvoering van het project 
gekeken wordt en de praktijkmedewerkers voor hun bijdrage bedankt worden;

- een bedankbrief aan alle participanten (huisartsen, doktersassistenten, patiënten) met samenvattende informatie over de voorigang en de resultaten van het project;

- de organisatie van een informele en informatieve projectbijeenkomst waarin de onderzoeker de belangrijkste bevindingen kan bespreken met de deelnemers en de parti cipanten persoonlijk voor hun bijdragen kan bedanken:

- de vermelding van een dankwoord (waar mogelijk met de namen van de partict panten) in de eindrapportage, het artikel of het proefschrift van het project.

Een goede nazorg kan van grote invloed zijn op de effecten van nieuwe wervingsac ties ten behoeve van nieuwe projecten.

\subsection{Evaluatie}

Vele wetenschappelijke projecten met vaak lange termijnen van data-verzameling hebben thun weg naar cle huisarts gevonden. Uit de gegevens van het Coördinatiebureau Eerste Lijn (CEL) blijkt dat circa $70 \%$ van de huisartsen van de universitaire regio van? de Rijksuniversiteit Limburg op enigerlei wijze een bijdrage heeft geleverd aan de uitvoering van het totale onderwijs- en onderzoekprogramma van deze universiteit. Een dergelijke participatiegraad mag groot genoemd worden.

Eveneens uit de ervaringen van het Coördinatiebureau Eerste Lijn kan geconcludeerd worden dat de gepresenteerde "modelbeschrijving werving affiliatie-praktijken" op hoofdlijnen in dle praktijk wordt toegepast.

In de voorbereidingsfase wordt doorgaans aandacht besteed aan de in het model genoemde aspecten van de uitvoerbaarheid, tijdsinvestering en financiering van het project. Niet altijd wordt een regionaal (praktizerend) huisarts in de projectgroep betrokken.

Ook de acceptatiefase verloopt volgens het model. De inhoudelijke en organisatorische acceptatie via respectievelijk de vakgroep huisartsgeneeskunde en her Coördinatiebureau Eerste Lijn is gebruikelijk. Bij grootschalige projecten wordt reeds in een vroegtijdig stadium contact gezocht met de Districts Huisartsvereniging of met regionale huisartsgroepen. Ook de ethische beoordeling via met name de medischethische commissies is usance. Hetzelfde geldt voor de financiële acceptatie. Uitvoering van extramurale projecten is doorgaans dermate kostbaar dat voldoende aandacht voor dit aspect vanzelfsprekend gevonden wordt. De voorwaarden en richtlijnen waaronder financièle acceptatie wordt verkregen zijn in de afgelopen jaren verscherpt. Lump-sum financiering, waarbij de subsidiegever een bepaald bedrag beschikbaar stelt voor de realisatie van de overeengekomen projectdoelen, maakt steeds meer plaats voor financieringsmodellen met ingewikkelde budgetteringsafspraken. Naast afspraken over het totale financiële volume van het project, worden specifieke afspraken vastgelegd over de jaarvolumes en over kostenplaatsvolumes (personeel budget, investeringen, reiskosten, kostenvergoedingen derden, overige materièle lasten).

Het is dan ook belangrijk reeds in de voorbereidingsfase inzicht te hebben in de financiële uitgangspunten van de beoogde subsidiegever. Deze behoren dan in de projectbegroting te worden verwerkt. Een essentieel maar door onderzoekers vaak vergeten element vormen de "veldkosten" voor hun project, met name die welke gereserveerd 
dienen te worden voor de huisartsdeelnemers. Een complicatie hierbij is dat veel sulsidiegevers deze post vaak nog niet erkennen. Steeds meer ziet men echter in, dat ook hier een professionele benadering nodig is en darvoor financiele middielen noodza. kelijk zin. Ook de wervingsfase verloopt grotendeels volgens model De gestructureerde en gecoördineerde aanpak via de vakgroep huisartsgeneeskunde en het Coördinatiebureau Eerste Lijn heeft duidelijk terein gewonnen. Hierbij moet worden aangetekend dat de niet-universitaire projecten slechts incidenteel via het CEL de weg natr de huisarts hebben gevonden. De verantwoordelike onderzoekers en docenten verschaffen doorgaans adequate informatie over de belangrijkste aspecten van het project. Vaak blijkt het echter moeilijk het wetenschappelijke protocol te herschrijen in woor de huisarts begrijpelijke en aansprekende bewoordingen. Het aanbieden wan het gehele protocol is van weinig waarde aangezien deze informatie soms te ingewikkeld: en altijd te uitgebreid is.

De modelmatige aanpak wordt niet gevolgd daar war het de inschakeling van "stakeholders" en "local champions" betreft. Met name de promotie van een nieuw project met behulp van "local champions" lijkt verbeterd te kunnen worden. Met de explosieve groei van het aantal (onderzoeks) projecten en gepromoveerde huisartsen zijn er steeds meer huisartsen aanwezig die op specifieke onderzoeksterreinen een meer dan gemiddelde (wetenschappelijke) deskundigheid bezitten. Itet vroegtijdig inschakelen wan deze deskundigheid kan de uiteindelijke werving alleen maar in positieve zin beinvloeden.

Het is van belang dat de onderzoeker/docent tijdens de uitvoeringsfase van het project met regelmaat de participerende praktijken bezoekt om onduidelijkheden te bespreken en de huisartsen en assistenten te motiveren hun belangrijke bijdrage te continueren. Daarbij kunnen schriftelijke voortgangstapportages een nuttige aanvulling vormen.

Ook de nazorgfase wordt in de meeste gevallen uitgevoerd conform het model. Aandacht voor adequate vermelding van de bijdragen van de diverse participanten, overdracht van de bevindingen naar de deelnemers bijvoorbeeld in de vorm van een voor lichtingsbijeenkomst en dankzegging wordt in de regel aangetroffen. 


\subsection{Literatuur}

1. Murphy $\mathbb{E}$, Spiegal $N_{x}$ Kinmonth AL "Will you help me with my researchi" Gaining access to primary care settings and subjects. Br your of General practice 1992; $42: 162-5$

2. Silagy CA, Carsoni NE Factors inflecting the leve of interest and activity in primary care research among general practioners. Fan Pract 1989: $6: 1736$

3 Borgiel AEM, Dunn EV, Lanont CT, et al. Recruiting family physicians as participants in research. Fann Pract. 1989; 6: 168 72

4. Herbert CP. Why family practice research? Canaclian Family Physician 1991; 37:335-8

5

Gagnon FA, Susak LE, Goulet FE. Getting started in family research (part 1). Canachan Family Physician $1991 ; 37: 596-601$

\section{6}

Gagnon FA, Susak LE, Goulet FE. Getting started in family research (part 2). Canadian Farnily Physician $1991 ; 37: 950-4$

7

Booth C. Research and the general practitioner. Br Med.J 1987; 295: $1614-9$

8

Douma S, Schreuder H. Economic approaches to organizations. Prentice Hall International Ltd. United Kingdom, 1992

9

Jacohs BM. Coondinatieburean Eerste Lijn; werkelijkheid of illusie? Doctoraalscriptie 1988 


\section{MODELBESCHRIJVING ACADEMISERING: DE THEORETISCHE ONDERBOUWING.}

\subsection{Inleiding}

In het verleden is diverse mallen geprobeerd te komen tot een modelbeschrijving van de academisering van de huisartsgeneeskunde, soms bedrijfskundig', soms economisch $^{12}$ en een andere keer vooral gericht op inhoudelijke dimensies ${ }^{11}$.

In dit hoofdstuk wordt gezocht naar een onderbouwing vanuit de organisatiekunde, warbij de typering van de netwerkorganisaties en de gekozen samenwerkingsvorm centraal staan. Dit alles werd bestudeerd vanuit de optiek en de doelstellingen van de universiteit.

In de organisatiekunde is de laatste jaren weel aandacht besteed aan relaties tussen organisaties ofwel interorganisationele netwerken. Mede vanwege matschappelike ontwikkelingen hebben organisaties steeds meer belang bij elkaar en wordi tot onderlinge samenwerking gekomen ${ }^{19}$.

Juist vanwege deze toegenomen aandacht is het belangrijk bij de bestudering van de organisatiekunde ten einde (delen van) een bepaald verschijnsel te verklaren "prismatisch" kijken te voorkomen. Prismatisch kijken houdt in dat bestudering van de diverse theorieën leidt tot de conclusie dat elke theorie op zijn eigen wijze relevant is voor de verklaring van specifieke onderdelen van het te bestuderen object.

Ook bij het belichten van academische huisartsgeneeskundige netwerken vanuit de organisatiekunde doet zich dit voor. Vele bedriffseconomische, arbeidskundige theorieën geven een gevoel van herkenning in relatie tot de dagelijkse realiteit van het netwerk. Prismatisch kijken leidt dan al snel tot een eindeloze opsomming van vele theorieèn met vaak geringe aanknopingspunten met het centrale onderwerp. Elke theorie is als het ware een bril, waardoor de werkelijkheid van de academische netwerken op een bepalde manier wordt bekeken. Welke bril ook opgezet wordt, een zekere herkenning wordt gevonden.

Om "prismatisch" kijken te voorkomen is het van het grootste belang cle centrale vraagstelling te expliciteren en van daaruit de selectie van de theoretische benadleringen te motiveren. Er is gekozen woor een benadering, waarbij de organisaties van zowel de universiteit als de huisartspraktijk qua ontwerp worden gekarakteriseerd. Dit gebeurt aan de hand van de door Mintzberg geschetste organisatiestructuren 10.

Vanuit de individuele organisaties is gekomen tot interorganisationele samenwerking in de vorm van een netwerk. Het verschil tussen een organisatie en een netwerk wordt besproken en de kenmerken en concepten van netwerken komen aan de orde, waarbij eveneens wordt stil gestaan bij de coördinatie van belangen en van transactieverkeer tussen de partners in het netwerk. De "waarom-vraag" van de samenwerking in een academisch netwerk wordt bekeken, waarbij de transactiekostenbenadering van 
Williamson ${ }^{17,}, 18$ als witgangspunt is gekozen. De moderne agency-theorie wordt in dit verband eveneens besproken.

Tenslotte worden de theorieên afgezet tegen het reeds gerealiseerde Huisartsgenees kundig Academiseringsnetwerk Maastricht, met de bedoeling aanknopingspunten te vinden voor toekonstige ontwikkelingen.

\subsection{Positionering van de individuele partijen}

Voor de positionering van de beide organisaties, de universiteit en de individuele huis: artspraktijk, wordt gebruik gemaakt van de theorieën van Mintzberg. Mintzberg ${ }^{10}$ heef cle diverse organisatiestructuren uitvoerig beschreven. Uitgaande van de voornaarnste coördinatiemechanismen, de belangrijkste delen van de organisatie, de ontwerpparameters en de situationele factoren worden diverse organisatiestructuren onderscheiden. Voor de beschrijving van de universitaire - en de huisartsorganisatie lijken twee geschetste structuren in aanmerking te komen. De huisartspraktijk kan, in zijn meest elementaire vorm, gezien worden als een zogenaamde eenvoudige structuur, terwiil de universiteit getypeerd wordt als een professionele bureaucratie. Kennis van de belangrijkste principes van deze organisatiestructuren is van belang voor een verdere bestudering van het gedrag van deze organisaties in het uiteindelijk ontwikkelde netwerk.

\subsubsection{De huisartspraktijk als eenvoudige structuur}

De eenvoudige structuur gaat uit van een aantal principes. De primaire coördinatie in deze structuur wordt door één centrale persoon verzorgd. De (strategische) top is dam ook het voornaamste en machtigste deel van de organisatie. Vaak bestaat de hele organisatie slechts uit de strategische top en een beperkte uitvoerende kern.

De belangrijkste ontwerpparameter is volgens Mintzberg ${ }^{10}$ centralisatie, waarbij standaardisatie in de organisatie ontbreekt (de zogenaamde "organische structuur").

Vaak betreft het jonge, kleine organisaties in een dynamische, maar eenvoudige omgeving. De organisatie is niet onderhevig aan mode-verschijnselen, terwijl er nauwelijks sprake is van hoogwaardige technologie.

Een eenvoudige structuur heeft als voordelen dat de leider in het algemeen een grondige kennis heeft van de gehele onganisatie, dat de organisatie door zijn eenvoud flexibel is en snel kan antwoorden op veranderingen in de omgeving. Bovendien is er doorgaans sprake van een grote gedrevenheid, met name vanuit de leiding.

Uiteraard zijn er ook nadelen te ontdekken. De afhankelijkheid van de leider is groot en veel lijkt af te hangen van de gezondheid en grillen van de centrale persoon. Vaak hebben de andere medewerkers in de organisatie niet altijd het idee dat ze actief en creatief kunnen participeren aan de diverse bedrijfsprocessen. Volgzaam gectrag is vaak een effect.

In de huisartspraktijk in zijn meest elementaire vorm is de huisarts te typeren als de machtige en strategische topfiguur, die vrij centralistisch opereert. Ook de aangegeven 
situationele factoren worden aangetroffen. Meestal gat het om kleine organisaties zonder hoogwaardige technologie: De omgewing kan getypeend worden als dynamisch en niet of nauwelijks modegevoelig.

Tegelijkertijd kan geconstateerd worden dat democratiseringstendensen en behoefte a an schaalvergroting, alsmede de toename van de aanwezige technologie geleid hebben tot angepaste organisatiestructuren. De grotere groepspraktiken en zeker de gezondheidscentra voldoen dan ook niet meer volledig aan alle genoende kenmerken vam een eenvoudige structuur. De aanwezigheid van professioned bestuurders, managers en directeuren in de grotere centra leidr tot een sinutie, waarbij deze organisaties kenmerken gaan vertonen van de professionele bureaucratie.

Alvorens dit organisatieontwerp verder uit te werken is thet van belang het begrip "bureaucratie" in dit verband nader toe te lichten. Het is oorspronkelijk afgeleid van het woord bureau (kantoor). De socioloog Max weber ${ }^{8}$ gaf het woord een zuiver tech nische betekenis en deze betekenis heeft het begrip bureaucratie in de literatuur van de organisatietheorie nog steeds. Een bureaucratie is dan een structuar waarin het gedrag van de organisatie en de daarin werkzame medewerkers van te voren is vastgelegd of voorspelbaar is (cloor standaardisatie). Deze voorspelbaarheid ontstaat door verfinde afspraken over werkprocessen, output of vaardighedenniveau, al dan niet in een gecentraliseend model ontwikkeld. In tegenstelling tot de bureaucratische structuur definieert Weber ${ }^{8}$ de organische structuur als een structuur waarin standaardisatie in de organisatie ontbreekt.

\subsubsection{De universiteit als professionele bureaucratie}

Een universiteit wordt door Mintzberg gepercipieerd als een zogenaande professionele bureaucratie. Naarmate het uit te voeren werk ingewikkelder wordt is het van belang de "utwoerenden" (de professionals) rechtstreeks zeggenschap over het werk te geven. Het enige coördinatiemechanisme dat de organisatie in een dergelijke situatie heeft is "de standaardisatie van vaardigheden". Dit type van organisaties wordt de "professionele bureaucratie" genoend. Voorbeelden zijn ziekenhuizen, onderwijsinstellingen en universiteiten.

In de professionele bureaucratie hebben de professionals zeggenschap over de eigen werkzaamheden, hetgeen betekent dat de professional betrekkelijk onalihankelijk is van zijn collega's, maar nauw samenwerkt met zijn cliènten. De coördinatie wordt aangebrach door het ontwerp en de nomen die var tevoren vastleggen wat er moet gebeuren. Het hoofdbestanddeel van de professionele bureaucratie wordt gevonind door de uitvoefende kern. Doordat de nadruk ligt op de ütvoerende kern van professionals is decentralisatie een automatische comsequentie.

De professionals vragen doorgaans om een bestuurlike hierarchie die denocratisch en "botom-up" is, waardoor de rol van bestuurders ingewikkeld wordt. De bestuurder behoudt zijn macht zolang de professionals wan mening zijn dat hij hun belangen effectief dient. De macht van de bestururder kan eenvoudig worden overtroefd door de collectieve macht van de professionals, maat de besturder heef individueel wel meer macht dan de individuele professional.

In een professionele organisatie verliest het begrip strategie - een geintegreerd patroon van beslissingen dat geldt voor de hele organisatie - veel wan zijn betekenis. De strategie wordt voomamelijk bepaald door de undividuele professionals binnen de 
organisatie en de (beroeps)organisaties daarbüten. Strategie wordi dan al snel een cumulatie van effecten van projecten en individuele initiatieven uit de afgelopen periode.

Gebruikelike coördinatiemechanismen zoals direct toezicht, standaardisatic van werk processen en output hebben meerdere malen bewezen niet te voldoen in een profes. sionele bureaucratie ${ }^{10}$. Coördinatie in professionele bureaucratieën geschiedt vooral door standaardisatie van vaardigheden, maar dit wordt een indirect en vaag coördinatiemechanisme genoemd ${ }^{8}$.

Veranderingen zijn alleen dan te realiseren als de professional dat zelf wil. Het is dan ook zeer moelink in een dergelijke organisatie om te gaan met professionals die ofwe onbekwalam of nalatig zijn. Dankzij hun vrijheid van handelen negeren sommige professionals de behoeften en vragen wan de organisatie waarvan zij deel uit maken. Doordat professionals beetje bij beetje veranderen treden er ook veranderingen op in de professionele bureaucratie.

\subsection{Organisatie en netwerk}

Van der Zwaan 19 beschrijft in "Netwerken: samenhang en samenwerking in de gezondheldszorg" het verschil ussen een organisatie en een netwerk. Een netwerk wordi gedefinieerd als een verzameling van min of meer samenwerkende organisaties. Uitgaancle van deze definitie is er sprake van een principieel onderscheid wssen een organisatie en een netwerk. Anders had de definitie moeten luiden: "een netwerk is een organisatie van samenwerkende organisaties."

Intuitief zijn sommigen echter van mening dat een netwerk wel degelijk een bepaald type organisatie is, die zich hoogstens onderscheidt van de modale organisaties vanwege een verschil in aggregatieniveau. Ook in de definitie van Keuning en Eppink komen organisatie en netwerk dicht bij elkaar. Zij beschrijven een organisatie als een doel-realiserend samenwerkingsverband met als belangrijkste kenmerken :

\section{MENSEN DIE SAMENWERKEN VOOR EEN BEPAALD DOEL.}

Van der Krogt ${ }^{9}$ beschrift (interorganisationele) netwerken als organisaties, die onderlinge relaties angaan, hetzij als gevolg van wederzijdse afhankelijkheid (input-output relaties); hetzij als strategie met het doel de ongeving te beinwloeden.

De bestudering van netwerken was oorspronkelijk voornamelifk gebaseerd op het feit dat deze bestudering andere theorieèn zou vergen dan de beschikbare theorieèn ten aanien van individuele organisaties. Geleidelijk aan wint al met al de gedachte veld dat de bestudering van individuele organisaties en netwerken kan geschieden wanuit eenzelfde perspectief. "Een netwerk van organisaties kan immers net zo goed een organisatie van organisaties, een organisatie van de tweede graad genoemd worden"4. Dat wil niet zeggen dat er geen verschillen bestaan tussen nerwerken en organisaties, maar de noodzalak tot de hantering van andere organisatie-theorieën lijkt niet aanwezig. Tevens mag verondersteld worden dat, naarmate de formalisatie van en in het netwerk toeneemt ook de vergelijkbaarheid met individuele organisaties wordt verhoogd. 


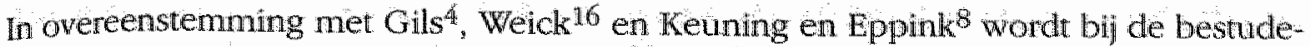
ring van academische huisartsgeneeskundige nerwerken gekozen voor een defintie waarbij een netwerk een bepaald type organisatie is. Enkele gangbare organisatietheorieën kunnen vervolgens gehanteerd worden voor de typering en de bestudering wan deze interorganisationele netwerken.

\subsection{Netwerken; soorten, strategie en "spel"}

De laatste tientallen jaren is de aandacht voor het "netwerk-concept" sterk toegenomen. Om allerlei redenen en op diverse manieren probeerden organisaties tot netwerkworming te komen, meestal uit vrije wil, maar soms ook gedwongen of tenminste door externe druk. Bij dit laatste kan gedacht worden aan netwerkworming in het mid. delbaar en hoger onderwijs mede als gevolg van het overheidsbeleid dienaangaande. In het universitair onderwijs wordt iets dergelijks gezien bij de ontwikkeling van interuniversitaire werkgroepen en onderzoekscholen.

Godfroil ${ }^{5}$ onderscheidt 9 verschillende netwerkvormen:

- Uirwisselingsnetwerken

- Circuits

- Financiëlle netwerken

- Elite-nerwerken

- Technische netwerken

- Ontwikkelingsnetwerken

- Beleidsnetwerken

- Coalitienetwerken

- Competitieve nerwerken

Het zou te ver voeren alle genoemde netwerkvormen te bespreken. Vandaar een korte uiteenzetting over de voor huisartsgeneeskundige academiseringsnetwerken meest relewante vormen, het uitwisselingsnetwerk, het beleidsnetwerk en het coalitienetwerk.

Een uitwisselingsnetwerk berust op min of meer duurzame relaties tussen verschillende organisaties, waarbinnen transacties plaatsvinden. Onder transacties wordt dan verstaan het ruilen van middelen of prestaties, watrbij de individuele organisaties voor het bereiken van hun doelen belang hebben. Bil de ruil is niet alleen de economische calculatie van belang, maar ook normen, watarden, tradities en machtsverhoudingen. Zou het namelijk alleen om economische calculaties gan, dan zou via de normale "markt" het doel van de organisaties bereikt kunnen worden.

In uitwisselingsnetwerken is het uitwisselingsgedrag voor beide partijen van groot belang voor de realisatie van de doelen; er is sprake van complementariteit (beide parvjen hebben elkaar iets te bieden), in de organisatieleer ook wel symbiotische interdependentie genoemd5.

Een beleidsnerwerk is een netwerk, waarin de actoren weliswaar een zelfde beleidsveld proberen te besturen, maar waarin zilj handelen vanuit verschillende definities, belangen, visies en vooral met üteenlopende beïnvloedingsmogelijkheden.

Coalitienetwerken tenslotte komen tot stand vanuit de behoefte van de actoren om door middel van krachtenbundeling sterker te staan tegenover een derde partij, die 
voor beide een bedreiging vormut. De bespreking van de diverse soorten netwerken wordt beperkt tot dieze drie varianten ondat deze als het meest rellevant voorkomen voor de academische netwerken. Hierop wordt later in dit hoofdstuk dieper ingegaan.

Bij de bestudering van processen in interorganisationele netwerken staan de begrippen "strategie" en "spel" vaak centraal 5, 8, 15. Voordeel van de hantering van deze begrippen als sleutelwoorden in de analyse is het verkrijgen van een redelijk inzicht in de dynamiek en de interactieprocessen van netwerken. Tegelijkertijd moet geconstateerd worden dat de theorieën moeilijk te vertalen zijn in heldere en toetsbate proposities en hypothesen.

Met andere woorden, de overtuigingskracht is groot, maar de bewijsvoering in thet algemeen gering.

De strategie is de belangrijkste gemeenschappelijke drijfveer van de organisaties om tot samenwerking in een netwerk te komen. Vijf belangriike strategieën zijn het maken van winst, het verhogen van de dienstbaarheid aan de cliënt, het simpelweg overleven, het behouden dan wel vergroten van macht of het verder ontwikkelen van kennis en vaardigheden. Deze laatste strategie wordt door van der Krogt ${ }^{9}$ cok wel de strategie van de waarde van het vak genoemd.

Können, Wassenberg en Godfroij 5,8,15 onderscheiden 7 verschillende speltypen:

- coöperatie

- coalitievorming

- comperitie

- competitiebeperking

- strijd

- conflictbeheersing

- schimmenspel

Ook hier wordt weer, vanuit het oogmerk een vertaalslag te kunnen doen naar de academische netwerken, een pragmatische keuze gemaakt voor de meest voor de hand liggende spelvormen, te weten coöperatie, coalitievorming en schimmenspel.

cooperatie of samenwerking is een speltype watin het realiseren van gemeenschappelijke doelstellingen dan wel her vergroten van wederzijdse voordelen voorop staat door onderlinge afstemming tussen de organisaties.

Bij coalitievorming berust de interdependentie tussen de netwerkpartijen met name op de bescherming of afscherming jegens een andere actor.

Het speltype 'schimmenspel' tenslotte gaat uit van het principe dat de partijen in het netwerk zich bewust zijn van hun interdependentie, matar niet altijd een duidelijk beeld hebben van hetgeen zij te winnen of te verliezen hebben.

\subsection{Netwerken; onrust en paradox}

In Wassenberg's "Netwerken : organisatie en strategie"15 worden bepaalide aspecten van netwerken nader uitgewerkt. De voorwaarden, die van invloed zijn op de ontwikkeling en instandhouding van samenwerkingsnetwerken worden beschreven, evenals de wanneer-vraag, waarbij dieper wordt ingegaan op het moment, waarop organisaties - 
uit vije wil of pure noodzak - ingaan op de mogelifheden van netwerken. De titel wan her eerste hoofdstuk wan dit boek Netwerken: rivaliteit en samenwerking tussen organisaties ${ }^{t 15}$ is in hoge mate typerend voor de onschriving van een huisartsgeneeskundig academiseringsnetwerk.

"Just wanuit de menging van conflict en samenwerking en vanuit het streven natut: autonomie en identiteit moet bezien worden hoe organisaties hun externe relaties doseren en nuanceren en daamee een verschijnsel veroorzaken dat men de "onrust van netwerken" zou kunnen noenen. " 15

Twee aspecten verdienen bij interorganisationele samenwerking in netwerken bijzondere andacht:

- het gaat bij netwerken van organisaties om mengyormen van rivaliteit en samenwerking; - er is sprake van dynamische wisselwerking tussen de interne (cle eigen onganisatiestuctuur van de beide partijen) en de externe (netwerk)structuur.

Bovengenoemde twee aspecten zijn van wisselend belang in de diverse ontwikkelingsstadia van organisaties. Het ritme van de ontwikkelingen wordt nu eens bepald door her netwerk zelf en dan weer door de ontwikkeling bij eên van de deelnemende partijen. Om een voorbeeld te geven. De introductie van het standardenbeleid ${ }^{20}$ in de huisartsgeneeskunde was een ontwikkeling met primaire consequenties voor het dagelijks werk van de huisartsen. Toch blijkt dat deze ontwikkeling ook gewolgen heeft voor de doelen en werkwijze van het totalle newwerk, inclusief het universitaire onderwijs en onderzoek. Bovendien is dit standaardenbeleid van grote invloed op de positie die de huisartsgeneeskunde inneemt in de samenleving en naar andere maatschappelijke organisaties toe. Op het niveau van het netwerk kan vervolgens besloten worden dat de effecten van de introductie van de standaarden in de huisartspraktijk wetenschappelijk gemeten moeten worclen. Deze ontwikkeling, beginnend bij het netwerk, leidt dan weer tot vervolgontwikkeling bij de deelnemende partijen.

De "netwerkparadox" kan, tegen deze achtergrond bezien, als volgt omschreven worden: "Het maken van afspraken in netwerken leidt weliswaar tot toename van zekerheid en voorspebaarheid van de te beinvloeden omgeving, tegelijkertijd worden de individu. ele organisaties in hun vrijheid wan handelen beperkt:19 Vanuit deze retlenering en vanuit de gedachte clat organisaties quat omvang en hièrarchie sterk verschillen was de verwachting gewettigd dat interorganisationele samenwerking slechls moelzam tot stand zou komen. Het blijkt echter dat wederzijdse belangen en percepties van veel grotere invloed zin op het succes van netwerken. Elkaar aanvullende organisaties komen derhalve, ook al. zijn er schaal- of hièrarchieverschillen, sneller tot interorganisationele samenwerking. Een belangrijke factor met betrekking tot netwerken is de relatieve macht van de participenende organisaties ten opzichte van elkaar. De initiatiefnemer is vak de machtigste partij, maar door de ontwikkeling van spelregels kan de macht van de overheersende partij worden gereguleerd dan wel beperkt.

\subsection{Coördinatie en beheersing van de taakuitoefening}

Om de onrust en machtsvaagstukken in netwerken te beperken is de aandacht voor coördinatie en beheersing van de takwitoefening essentiêel. Mintzberg ${ }^{10}$ onderscheidt 5 coordinatiemechanismen: 


\section{Onderinge aumpassing.}

Bij onderlinge aanpassing wordt het werk gecoördineerd via het simpele proces van informele communicatie. De controle van het werk is in handen van de mensen die het uitvoeren. Alhoewel dit coördinatiemechanisme voornamelijk gebruikt wordt in eenvoudige organisaties, blijkt onderlinge anpassing door informele communicatie ook in specialistische organisaties van groot belang te kunnen zijn.

\section{Direct toeztcht.}

De coördinatie komt tot stand doordat éên persoon de verantwoordelijkheid draagt; de instructies geeft en de uitvoering van de werkzaamheden bewaakt.

\section{Standaardisatie van werkprocessen.}

De inhoud van her werk wordt gespecificeerd of geprogrammeerd doordat expliciet vastgelegd wordt op welke wijze de werkzaamheden verricht moeten worden.

\section{Standaardisatie van output.}

De coördinatie komt hier tot stand doordat de resultaten van het werk zijn gespecificeerd, De resultaten kunnen dan zowel concrete gegevens zijn (afmetingen, aantallen) als prestaties of prestatieniveau's.

\section{Standaardisatie van vaardigheden en kennis.}

Het soort training dat voor de uitvoering van de werkzaamheden vereist is, is gespecificeerd.

In het algemeen kunnen meerdere coördinatiemechanismen naast elkaar worden gebruikt.

Groot ${ }^{6}$ geeft aan dat door complexiteit van de voortbrenging van de output of door de beperkte meetbaarheid ervan vaak wordt overgegaan tot delegatie van de managementfuncties aan de uitvoerders. Het is dan van belang daarover goede afspraken te maken. De wijze waarop dit kan gebeuren wordt onder andere door de transactiekostentheorie en de agency-theorte beschreven. Vanwege het belang van deze theorieern voor de academische netwerken worden ze kort beschreven.

In tegenstelling tot de traditionele economische theorieèn gaan de agency-en de transactiekostentheorie niet uit van het gegeven dat de betrokkenen beschikken over alle informatie ten asnzien van de produktiviteit van de werknemers. Het blijkt namelijk valak problematisch het exacte resultaat te meten (wat is het resultat) of te bepalen welk deel van het resultaat toegewezen kan worden aan bepaalde werknemers (wie heeft het resultaat bewerkstelligd). Ook ontstaan er meetfouten als gevolg van externe omstandigheden, die niet veroorzaakt zijn door de werknemer(s).

\subsubsection{Transactiekostentheorie}

Coase $^{7}$ introduceerde in 1937 de transactiekostentheorie, waarbij hij transactiekosten definieerde als zijnde de kosten die met het prijsmechanisme zijn geassocieerd om de juiste prestatieprikkels en coördinatie te bewerkstelligen. Hierbij kan worden gedacht aan kosten samenhangende met het onderhandelen, het opstellen van contracten, het 
umoeren wan inspecties (monitoring) en het treffen van voorzieningen voor eventuele geschillen. Willamson ${ }^{17}, 18$ heeft de transactiekostentheorie nader uitgewerkt, warbij hij zich ook heeft beziggehouden met de vraag in hoeverre transacties binnen een onderneming verschillen van transacties tussen verschillende ondememingen. Hij definieert transactiekosten in ruime zin als de middelen die nodig zijn bij de onderhandeling over contracten, de tijd die gemoeid is met het afdwingen en sluiten van de contracten en de kosten die gepaard gaan met het voorkomen van ontduiking van gemaakte afspraken. Een transactie wordt door hem omschreven als een ruil of uitwisseling van diensten, goederen of gunsten tussen individuen, groepen of organisaties.

Het ruil- of transactieproces tussen de organisaties kan zich in twee hoofdvormen voltrekken. Als er sprake is van een ruil tussen in beginsel gelijksoortige, gelijkwardige of elkaar aanvullende partijen en het prijsmechanisme central staat voor de regulering van het transactieproces is er sprake van een eenuoudige marktorganisatie. Prijsmechanisme moet in dit verband ruim gezien worden en kan derhalve ook bestan uit de nul van goederen, diensten en wederdiensten.

Tegenover de eenvoudige marktorganisatie definieent Williamson de zogenaamde biënarcbie. De gezagsrelatie of de hiërarchie en bureaucratische procedures vormen hierbij de basis voor het transactieproces.

Afhankelijk van de omstandigheden kunnen specilieke contractvormen leiden tot reduktie van de transactiekosten. Daarbij worden drie hoofdvormen oncerscheiden, te weten de korte termijn contracten, de lange termijn contracten en de verticale integratie. Bij relaties met geringe specifieke investeringen voldoet een korte termijn contract. Slecht gedrag wordt simpel afgestraft door met een andere marktpartij in zee te gaan. Daarom noent men deze contractvorm ook wel simpelweg "markr".

Zijn er veel specifieke investeringen noodzakelijk en is er een geringe onzekerheid over het nakomen van de afspraken, dan lijkt een lange termijn contract voor de hand liggend. Het hebben van goede relaties en van een goede reputatie is in dit ver band wan groot belang. Vaak zullen lange termijn contracten onvolledig zijn. Het is vrijwel onmogelijk en in ieder geval zeer kostbaar om alle mogelijke omstandigheden in kaart te brengen en in een overeenkonst mader te specificeren. Uiteraard is het zo dat onvolledige contracten leiden tot additionele transactiekosten, matr deze zijn wellicht lager dari de kosten gemoeid met het maken van "volledige contracten".

Verticale integratie tenslotte is een manier om bepaalde problemen in situaties met weel specifieke investeringen op te lossen, door zulke transacties binnen de organisatie op te nemen:

De mate van zekerheid over het gedrag van de transactie-partijen en de hoogte van de specifieke investeringen spelen dus een grote rol bij de vaststelling van de optimale contractvorm of beheersstructuur. In figuur 5.1. wordt de contractvormen schematisch weergegeven.

Samenvattend kan gezegd worden dat de transactiekostenbenadering de problemen benadrukt die geassocieerd kumnen zijn met onvolledige contracten in relaties met in principe niet-recupereerbare investeringen. De partijen zijn als het ware tot elkaar veroordeeld, vaak ondat de wederzijdse investeringen binnen hun relatie een hoge waatde hebben. 
MATE WMN ONLEKRRHEDC

GERING

GROOT

\begin{tabular}{|c|c|c|c|c|}
\hline $\begin{array}{l}\text { MTE WAN SPECIIUEKS } \\
\text { WWESTERTOGEN }\end{array}$ & GERING & $\begin{array}{l}\text { Konte temijn } \\
\text { contract }\end{array}$ & $\cdots$ & $\begin{array}{l}\text { Korte termijn } \\
\text { contract }\end{array}$ \\
\hline & GROOT & $\begin{array}{l}\text { lange terming } \\
\text { contract. }\end{array}$ & & $\begin{array}{l}\text { verticale } \\
\text { integrate }\end{array}$ \\
\hline
\end{tabular}

\subsubsection{Agency-theorie: de theorie van agent en principal}

In de zeventiger jaren werden de zogenaamde "agency-theorieen" ${ }^{\text {it }}$ ontwikkeld. In verschillende handboeken 3,6,13 wordt deze moderne accounting-theorie uitvoerig beschreven. Binnen de agency theorie zijn twee stromingen te onderscheiden:

\section{- de positieve agency theorie}

De positieve agency theorie heeft als titgangspunt dat bestaande organisatie-vormen efficient zijn, aangezien ze anders niet blijvend zouden bestaan. De belangrijkste onderzoeksvraag in de positieve agency-theorie betreft de mate waarin contrac ten het gedrag van de participanten zullen beinvloeden.

\section{- de theorie van principal en agent}

Centrale vraag van deze theorie is de wijze warop de "principal" de (belonings) relatie met de "agent" moet onderhouden. Vaak leidt de beantwoording van deze vrag tot formele rathematische modellen.

Alhoevel oorspronkelijk bedoeld als mathematisch, economisch model, werden al vrij snel gedragswetenschappelijke overwegingen aan het model toegevoegd. In de meest simpele vorm beschriff de agency theorie de relatie tussen twee personen of organisaties, een "principal" en een "agent", die namens de principal besluiten neemt. Elke persoon kan dan eens principal en de volgende keer agent zijn. In het patientenzorg-contact tussen patient en arts is de patiènt principal en de huisarts de agent, wiens beslissingen van invloed zullen zijn op de gezondheid van de patient. In het overleg tussen de huisarts en zijn accountant wordt de hussans weer de principal, die zich zal laten leiden door de adviezen van de agent (de accountani). In de algemene theorie van principal en agent stat de wijze waarop de principal het gedrag van de agent kan obserweren (èn beinvloeden) centraall.

Dre vormen zijn in dit kader van belang.

In de eerste plaats de simatie waarbij de principal de agent wolledig kan obsenveren (de chef van de typekamer, die de typistes in directe zin kan observeren en beinvloeden). Ten tweede zijn er uiteraard ook vormen denkbaar, waarbij de principal geen enkele imformatie heeft over het gedrag van de agent.

In de derde vorm kan de principal het gedrag van de agent weliswaar niet direct beinvoeden, maar kan hij signalen ontvangen met betrekking tot het kwalitatieve en kwantitatieve niveau van de inspanningen van de agent.

In de relatie tussen de universitaire vakgroep huisartsgeneeskunde en de individuele huisarts lijkt de derde vorm van de agency theorie het meest relevant. 
Groo ${ }^{6}$ wijst op enkele factoren, die van invloed kunnen zijn op de af te sluiten con racten tussen agent en principal. Alereerst geeft hil an dat het door de agent te bereiken resultaat niet alleen afhankelijk gesteld kan worden van de inspanning van de agent, aangezien er een zekere afhankelijkheid is van omgevingsfactoren. Dit opent wolgens Groot de mogelijkheid om te onderzoeken op welke wijze risico-verdeling tussen de partijen kan plaatsvinden en hoe dat in de beloningsstructuur tot uiting zou kunnen komen. $O p$ de tweede plaats kan het zo zijn dat de agent een inspanningsniveau kan kiezen dat niet door de principal kan worden gecontroleerd, hetgeen er toe kan leiden dat de agent de eigen nutsfunctie maximaliseent ten koste van de nut tigheid voor de principal. Men kan deze suboptimalisatie tegengaan door informatie in te winnen over het inspanningsniveau van de agent of door het minimaal acceptabele output-niveau vast te stellen en een boete te geven bij onderschrijding van clit niveau.

Afhankelijk van de mate, warin informatie over het gedrag van de agent beschikbaar is worden in de agency-theorie drie typen contracten onderscheiden ${ }^{3}$. Daar war de principal het gedrag van de agent (redelijk) goed kan beoordelen kan een eenvoudige contractvorm, een "forcing contract" dienst doen. Afgesproken wordt dat de principal een bepaald bedrag betaalt; wanneer de agent een van te voren bepaald minimum-prestatieniveau haalt. Wordt dat niveau niet gehaald, dan volgt geen enkele betaling.

Het woordeel van deze contractvorm is dat de agent alles zal doen om het gevraagde niveau te halen; tegelijkertijd wordt ook het nadeel zichtbaar. Als het niveau eenmaal gehaald is, zal de agent doorgaans geen verdete inspanningen meer doen.

Indien het gedrag van de agent niet (goed) te beoordelen is worden twee andere contractsoorten voorgesteld, te weten het "wage contract" en het 'rent-contract'.

Het "wage contract" wordt nog steeds veel toegepast en betekent dat de agent een gefixeerd sallaris ontvangt, ongeacht de prestatie. De beloning is min of meer taakafhankelijk en niet prestatie-afhankelijk. Het belangrijkste nadeel van deze belonings systematiek is het ontbreken van een incentive voor de agent om extra inspanningen te verrichten. Bij een wage contract ligt het risico geheel bij de principal.

Bij een "rent contract" ontvangt de agent de volledige opbrengst minus een van te voren overeengekomen bedrag. Het risico ligt bij deze vorm geheel bij de agent.

\subsection{Nadere analyse van de praktijk van het academiseringsnetwerk in relatie tot relevante theorieën}

Terwill in het woorgaande reeds op sommige platsen de relevantie van de beschreven theorie voor de concrete uitwoering van geacademiseerde huisartsgeneeskundige netwerken is angeduid, is het van belang de belangrijkste uitgangspunten en theorieèn samenhangend te relateren aan de praktische realiteit van het academiseringsnetwerk. in figuur 5.2 worden de besproken theorieën schematisch weergegeven.

De mate waarin deze theorieen van toepassing zijn op het huisartsgenecskundig academiseringsnetwerk Maastricht (HAM) kan worden getoetst aan de hand van concrete uitwoeringsaspecten, zoals de gehanteerde contracten, de inhoudelijke werkplannen, de geformuleerde doelstellingen en de wijze waarop de twee partijen (universiteit en veld) elkaar gevonden hebben. 


\section{Theorie}

De huisartspraktijk als eenwoudige structuur 8,10

Professionele

bureaucratie $^{1, B_{i}} 10$
Interorganisationele samenwerking (IOS) 1,8

Frinsactiekostentheorie 17,18

\section{Beschrifte de transacties tussen} organisaties atur de havd wan de kosten, alsmede de contracwormen.
Belangrijkste kenmerken van de theorie

1. Coordinatie door centraal toeziclit, centraal dour Eén (tog) man

2. De strategische top is het belangriikste en machtigste deel wan de organisatie

3. Centralisatie; weinig standaardisatie

4. Benvoudige, dynamische ongeving; geen hoogwa ardige techinologie

1. Coördinatie door standaardisatie van wardigheden (training), het ontwerp en de nomen

2. De krachit ("macht") ligt bil) de vilwoerende kern van de jorofessionals:

3. Professionals hebbem zeggenschap over de "eigen" werkzaamheden

4. Decentralisatie en taakspecialisatie

5. Irigewikkelde, maar redelijk stabiele ongeving

6. Niet-regulerend en technisch niet te complex systuen

7. Democratische besiturli ike hiêrarchie (bottom-up)

8. Strategie-bepaling vanuit de professionals op basis van effect-evaluatie van uitgevoerde projecten en initiatieven

Het samenwerkingsdoel overlapt slechts gedeeltelij| de afronderlijke doelen van de deelnemende organisaties.

Transactiekosten in ruime zin worden onschireven als de middelen die nodig zijun bij de onderhandeling over contracten, de tijd die gemoeid is met het afflwingen on shiten van de contracter cen de kosten die gepaard gaan met het woorkomen wan ontduiking van gemaakte afspraken. Ien transactie is cen ruil of uitwisseling van diensten; goederen of gunsten tussen individuen, groepen of organisaties.

1. De principal kan het gedrag van de xgent niet dinect beinvloeden, maar kan slech ss signalen ontvangen met betrekking tot het kwalitatieve en kwantitatieve niveau wan de inspamningen van de agent.

2. De centrale vraag in de agency theorte is hoe de principal de beloningstructiut wan de agent(en) moet inrichten. 
In zin meest elementaire vorm kan de huisartspraktilk getypeerd worden als een cenvoudige structurur" De organisaties zin vak klein en de omgeving weluswar dynamisch, maar tegelik eenwoudig. De strategische top van de organisate, de huisarts zelf, vormt het voomaamste deel van de organisatie. Centralisatie is de belangrijkste ontwerpparameter.

Tegelijkertij moet echter geconstateerd worden dat, als gevolg van schalvergroting en democratiseringstendensen, de modemere huisarts-organisatievormen (groepsprakujken en gezondheidscentra) niet meer aan alle kenmerken van de eenvoudige structuur voldoen. Vaak wordt de organisatie gestuurd door beroepsbestuurders en door een directeur met een beheersmatige eindverantwoordelikheid. De coördinatie vindt niet meer plaats door direct toezicht, maar steeds meer door standaardisatie van vaardigheden en werkprocessen. Het standaardenbeleid van het Nederlands Huisartsen Genootschap heeft deze tendens versterkt. Huisartspraktijken gaan dan al snel de kenmerken van een professionele bureaucratie vertonen.

De kenmerken van de "professionele bureaucratie" zijn niet alleen zichtbaar als gevolg van het feit dat universiteiten getypeerd kunnen worden als professionele organisaties, maar zijn eveneens aanwezig in het concept van de geacademiseende netwerken. In het netwerk is gekozen voor een hoge mate van decentralisatie naar het niweau van de "professionals" (de geacademiseerde huisartsen). Deze professionals hebben zeggenschap over de uirvoering van de eigen werkzaamheden, daarbij slechts gestuurd door de jaarliks overeen te komen inhoudelijke werkplannen. Alhoewel het niet eenvoudig is te spreken over de machtsverhoudingen in het netwerk, is geprobeerd te komen to gelijkwaardigheid van de verhoudingen tussen de universitaire wakgroep en de geacademiseerde huisauts, binnen de grenzen gesteld door de gezamenlijk onderschreven doeleinden.

De inhoudelijke kracht (macht) van het netwerk ligt nadrukkelijk bij de uitvoerende kern van het netwerk, bij de professionals.

De coördinatie in professionele bureaucratieën vindt hoofdzakelifk plaats door standaardisatie van vardigheden. De geacademiseerde huisartsen, de professionals in dit verband, kmijgen daartoe opleidingen op het gebied van onder andere didactiek en wetenschappelijke vorming, methodologie en statistiek.

Strategiebepaling vindt hoofdzakelijk plaats door de professionals zelf; een eenzijdige top-down benadering heeft zelden effect. In het Huisartsgeneeskundig Academiseringsinetwerk Maastricht wordt beoogd de strateglicbepaling te faciliteren door het inbouwen van een additioneel bestuursorgan, het Dagelijks Bestuur Academiserting. De professionals zijn in dit bestuursorgaan ruimschoots vertegenwoordigd Er wordt nas gestreefd via het dagelijks bestuur academisering invulling te geven aan de noodzakelijke, gezamenlijke strategiebepaling.

Schema 5.3 geeft een overzicht van de belangrijkste kenmerken van de "eenvoudige structuur" en de "professionele bureaucratie" en de mate waarin het Huisartsgeneeskundig Academiseringsnetwerk Maastricht aan deze kenmerken voldoet. 
Onderwerp/kenmet k"

extwoudige structuur

professionele bureaucratie

Primair coördinatie- direct toezicht

mechanisme

Centrale deel vari

de organisatie

Specialisatie wan taken weinig specialisatie

Training en formalisatie weinig

van gedrag

Planning en controle

Belang van informele

communicatie

Besluitvorming

Technisch systeem

Ongeving strategische top

weinig

signilicant

top-down

eenvoudig;

niet regulerend

eenvoudig; dynamisch
Standarardisatie van

vaardigheden

uinoerende kem

veel horizontale

specialisatie

veel training

weinig formalisatie

weinig

significternt,

met name voor bestuur

bottom-up

niet-regulerend

of niet-geavanceerd

complex en stabiel
Het Fuisartsgeneeskundig

Academiseringsnetwerk

Marstricht (HAM)

Standaardisatie wan vaardighteden en standaardisatie wan outpot

uitwoerende kern met de

"strategische top" "un het

DB-academisering

veel horizontale

specialisatie

veel trasining

val formalisalie

in toenemende mate

significant, maar

moelitiker te realiseren

mengrarm

niet-regulerend

of niet-geavanceerd

relatief eenveudig

en stabiel

Het Hulsantsgeneeskundig Academiseringsnetwerk Maastricht voldoet eveneens aan de kemerken van een (interorganisationeeb netwerk. Netwerken zijn verzamelingen van min of meer samenwerkende organisaties. In het HAM zin dat de Rijksuniversiteit limburg enerzijds en de individuele huisartspraktijken (solo-praktijken, maatschap pen, stichtingen ed.) anderzijds. De deelnemende organisaties behouden hun eigen organisatievorm, terwijh het netwerk zelf ook een organisatievorm ontwiklkelt. Het HAM kan dan ook gezien worden als een "loosely coupled organisation ${ }^{16}$ oftewel een "Organisatie van de tweede graad"4.

Aan het belangrijkste keimerk van "interorganisationele samenwerking" word eveneens voldan. Her samenwerkingsdoel overlapt slechts ten dele de afzonderlike doelen van de deelnemende partijen.

De huisartsen nemen deel aar het netwerk ter reallisatie van uiteenlopende doelen, zoals "het leveren van een bijdrage aan de wetenschappelijke ontwikkeling van de discipline huisartsgeneeskunde" of "het opleiden van toekomstige collega's in de gezondheidszorg". Ook vergroting van de eigen deskundigheid is een erkend doel.

De universiteit kent als primaire doelstellingen onderwijs, onderzoek, ontwikkeling 
van patièntenzorg en matschappelijke dienstverlening. Om deze doelen te kuninen realiseren is het voor een vakgroep huwsartsgeneeskunde gewenst vrij direct toegang te hebben tot het eigen werkveld der pratitizerende huisartsen.

De keuze voor het geramte van de interorganisationele samenwerking sluit het meest an bij de "netwerktheorie". De typering van deze theorie als een dynamische wisselwerking tussen de interne, eigen organisatiestructuur van de beide partijen en de externe (netwerk)structur is algemeen voelbaar. Eveneens is permanente onrust merkbaar, aangezien de samenwerkingsioelen zelden kunnen prevaleren boven de eigen primaire doelen. Planning en uitvoering van onderwijs en onderzoek wordt weliswaar cloor de huisarts zeer belangrijk gevonden, maar krijgt altijd een lagere prioriteit dan de primaire patièntenzorg-taak. Rivaliteit en samenwerking gaan dan ook hand in hand.

Redenen om de interorganisationele samenwerking in netwerkvorm aan te gaan kunnen zowel vanuit de "ruiltheorie" als de "coalitietheorie" onschreven worden.

De ruiltheorie is clirect herkenbaar. De opbrengst van de samenwerking in het netwerk zou voor beide partijen niet gerealiseerd kunnen worden zonder deze samenwerking. De stabiliteit van de samenwerking is in hoge mate afhankelijk van de wederkerigheid (gelijkwaardigheid) van de partjen; De universiteit zal moeten onderkennen dat de zeggenschap over de zorg in het netwerk bij de vitvoerende professionals (de geacademiseerde huisartsen) ligt, terwijl de huisarts zal moeten inzien dat de universitaire vakgroep in termen van concept-ontwikkeling, inhoudelijke wetenschappelitke programmering, financiering en besturing een beslissende rol speelt Reductie van machtsverschillen ten behoeve van een evenwichtige samenwerking is een belangrijk aandachtspunt. In de ruiltheorie zijn de nulobjecten vaak moeilijk te kwantificeren. Bevordering van de efgen deskundigheidsontwikkeling van de huisarts door participatie aan onderwijs wordt weliswaar doot de huisartsen ervaren, maar is zeer moelijk in maat en getal weer te geven. De aanwezigheid van studenten in de huisartspraktijk kan aanleiding geven tot creatieve discussies over de inhoud van het vak, die anders niet gevoerd zouden worden.

Ook de coalitietheorie lifkt van toepassing op de samenwerking tussen vakgroep huisartsgeneeskunde en huisartsen in academische netwerken. De huisartsgeneeskunde heeft als klnische discipline, evenals de klinische disciplines in de ziekenhuizen; grote behoefte an ontwikkeling en verdieping, niet alleen door onderwijs en onderzoek, maar ook door directe en indirecte ontwikkeling van de patientenzorg. Het academiseringsconcept is algemeen geaccepteerd in de ziekenhuisomgeving, terwijl dat nog niet het geval is bij de extramuraal werkende klinische disciplines. Door het verbond tussen de universitaire vakgroepen huisartsgeneeskunde en de beroepsgroep huisartsen is er in de afgelopen jaren waardering ontstaan vooi de noodzak van academisering van deze discipline. De coalitie heef in dit verband derhalve effectief gefunctioneerd. De coalitie was met name gericht op erkenning vanuit de hoek van de beleidmakers (ministerieel, universitair), alsmede vanuit de (academische) ziekenhuizen. Inmiddels lijkt het erop dat in de lokale situatie aan de Rijksuniversiteit Limburg het geimplementeerde huisartsgeneeskundige academiseringsconcept geaccepteend is. 


\section{Soorten netwerken}

Hot HAM ventont de meeste overeenkomsten met het concept van een zogenaamd uitwisselingsnetwerk, een netwerk dat berust op min of meer dururame relaties tussen verschillende organisaties, waarbinnen transacties plaatsvinden. Transacties omvatten: dan niet alleen het rullen van goederen, maat vak just diensten-uitruil. Beide partijen zin complementair a an elkar, ook wel symbionsche interdependentie genoemd.

Hoewel het netwerk, zoals eerder vermeld, wellicht ook mede berust op coalitie-kenmerken, $_{\mathrm{b}}$ dragt het uitwisselingsgedrag (de ruil) waarschijnijk nadrukkelijker bij aun het onstaan van het geacademiseerde netwerk.

De strategie, gedefnieerd als de resultante van de belangrijkste gemeenschappelike redenen van cle organisaties on tot samenwerking in een netwerk te komen, word door Van der Krogt ${ }^{9}$ verklaard aan de hand van vij mogelijke opties, te weten:

- het maken van winst;

- het venhogen vari de dienstbaarheid aan de chent;

- het simpelweg overleven;

- het behouden of vergroten van macht"

- het (verder) ontwikkelen van kennis en vaardigheden.

In geacademiseerde netwerken, zoals het HAM, lijkt het met name te gaan om verder ontwikkeling van kennis en vaardigheden in het betreffende vakgebied, in dit geval de huisartsgeneeskunde. Dit wordt ook wel de strategie van de waarde van het vak genoemd.

Kijkend nar de door Können, Wassenberg en Godfroy 5 , 8, 15 gehanteerde "speltypen" lijkt het voor de hand te liggen het spel in het HAM te verklaren aan de hand van het speltype coöperatie of samenwerking. In dit speltype worden de gemeenschappelijke doelstellingen, dan wel de wederzijdse voordelen gerealseerd door onderlinge afstemming tussen de deelnemende organisaties. De andere speltypen, zoals competitie, competitiebeperking, strijd en conflictbeheersing, lijken nauwelijks relevant voor de verklaring van het spel van geacademiseerde netwerken. Coalitievorming heeft als speltype wellicht enige betekenis. Zoals bij de coalitietheorie reeds angegeven is kan de interdependentie tussen de netwerkpartijen van het HAM mede verklatard worden an de behoefte aan bescherming of afscheming jegens andere actoren. Soms likk het speltype "schimmenpel" aan de orde; de netwerkpartijen zijn zich bewust van hun interdependentie, maar er is niet altijd een duidelijk zicht op hetgeen zij te winnen of te verliezen hebben. Dit geldt het meest woor de deelnemende huisartsen, woor wie de deelname berust op moeilik meetbare motieven, zoals "het valk vooruit helpen", "toekomstige collega's opleiden" of "de eigen deskundigheid verder ontwikkelen". Voov de universitaire vakgroep huisurtsgeneeskunde ligi dit duidelijk anders. Studenten vinden een "werkplaats" voor praktisch medisch onderwijs in de huisartsgeneeskunde, medewerkers kunnen actief participeren aan de dagelijkse patiëntenzorg en wetenschappelijk onderzoek wordt in hoge mate gefaciliteerd. De winst voor de deelname aan het netwerk is niet alleen direct zichtbaar, maar ook goed meetbaar.

Om onrust in het netwerk te voorkomen is het van groot belang aandacht te besteden aan de coördinatie en de beheersing van de takkuitoefening. De door Mintzberg ${ }^{10}$ geintroduceerde coördinatiemechanismen worden in het HAM naast elkaar gebruikt. 
Ondertinge aanpassing via informele communicatie is met name in het ontwiklelingstraject wan groot belang geweest, maar speelt nog steeds een belangrijke rol.

Direct noezicht lijkt minder relevant, mede doordat de participerende praktiken op geografische afstand van de universiteit hun werkzaamheden verrichten. Toch wordt door de aanwijzing van een hoogleraar, met de portefeuille academisering, de eind verantwoondelijkheid in principe bij één persoon gelegd. Ook de jaarlijkse praktijkbezoeken hebben het karakter van toezicht, in combinatie met het geven van instructies en het bewaken van de werkzamheden.

Standaardisatie van werkprocessen, watbij de inhoud van het werk wordt gespecifceerd of geprogrammeerd; vindt eveneens plats. In het praktisch medisch onderwijs bijvoorbeeld wordt uitgebreid aandacht besteed aan de wijze waarop de huisarts de rol van "opleider" zou moeten vervullen. In het wetenschappelijk onderzoek wordt eveneens veel aandacht besteed aan de wijze waarop de huisarts zijn bijdrage aan het onderzoek moet vervullen.

Standaandisatie van output is recentelijk bij de registratiewerkzaamheden van de geacademiseerde huisartspraktiken geintroduceerd. De resultaten van het werk zijn gespecificeerd in de vorm van aantallen op een juiste wijze te registreren patientgegevens. Ook bij de beoordeling van het wetenschappelijk onderzoek (ook in het kader van het academiseringsnetwerk) wordt in toenemende mate gekeken naar de output in de vorm van artikelen in relatie tot de ingezette capaciteit.

Standaardisatie van vaardigbeden en kennis is het meest gehanteerde coördinatiemechanisme. Naast algemene trainingen op het gebied van didactiek, wetenschappew lijke vorming, methodologie en statistiek, vinden er per specifiek project aparte introduktietrainingen plaats. Gedacht kan worden aan voorlichtings-, introduktie- en voortgangsbijeenkomsten van onderzoeksprojecten, (meerdaagse) workshops van projecten op het gebied van praktisch medisch onderwijs en trainingen georganiseerd door en voor de huisartsen van registrerende huisartspraktijken.

Ook de transactiekostentheorie is van belang voor de verklaring van bepaalde aspecten van het HAM. In de aanloopfase van het HAM is er veel tijd besteed aan de ontwikkeling van "volledige contracten". Toen het vrijwel onmogelik blleek alle nogelijke omstandigheden in een contract onder te brengen is op pragmatische wijze gekozen voor een concept van algemene, langlopende contracten in combinatie met jarlijkse werkplannen. De contracten kunnen gedeliniëerd worden als onvolledige contracten, aangezien stechts de hoofdlinen van de samenwerking in het netwerk nader zijn gedefinieerd. Tegelijkertijd kan geconstateerd worden dat de ontwikkeling en instandhouding van academische netwerken hoge investeringen vraagt. Naast de in hoofdstuk 3 beschreven directe "transactiekosten", zoals salarissen, investeringen in. bouw en investeringen in (computer)apparatuur, zijn er kosten samenhangende met het opstellen en onderhouden van de contracten, het onderhouden van de contacten, het toezicht houden op de taakuitoefening, de organisatie van workshops en de bestuurlijke en beleidsmatige sturing van het netwerk. De jaarlijkse kosten van het HAM bedragen met inbegrip van de hierboven genoemde "indirecte" transactiekosten in ieder geval $\mathbb{F}$. $1.500,000$ =, hetgeen een aanzienlijke investering genoemd kan worden. In het kader van de transactiekostentheorie vinden de transacties plaats middels de "eenvoudige marktorganisatie". In beginsel gelijkwaardige partijen komen in deze organisatievorm tot ruil van goederen, diensten of gunsten. 
Afhankellk van de zekerheid over het nakomen van de gemaakte afspraken en wan de hoogte van de investeringen komt Williamson tot drie contractwormen, te weten korte termin contracten, lange termin contracten en verticale integratie ${ }^{17}$.

Bif hoge investeringen worden afhankelijk van de mate van onzekerheid over het nakomen van de afspraken de lange termijn contracten of verticale integratie voorgesteld. In het HAM is er sprake wan relatief hoge investeringen. In hoofdstuk 3 is reeds angegeven dat gekozen is voor een systeem van langdurige contracten; met de mogelijkheid voor de geacademiseerde huisartsen om in dienst te treden van de unversiteit. Dooir deze aanstellingen komen de transacties als het ware binnen de organisatie wan de universiteit te liggen (verticale integratie). De in het HAM gekozen systematiek komt dan ook overeen met de voorgestelde contractvormen in de transactiekostentheorie.

Tenslotte wordt een recentere visie, de zogenaande agency theorie $3,6,8,13$ beschreven. Daatin wordt de relatie tussen tovee personen (partijen); een "principal" en een "agent", die namens de principal besluiten neemt, verhelderd. Fén van de specifieke women van de agency-theorie gat uit van de situatie dat de principal (de universiteit) slechts enkele signalen ontwangt over het kwalitatief en kwantitatief functioneren var de agent (de geacademiseerde huisarts). Er is geen directe controle of beinvloeding mogelijk of wenselijk. De centrale vraag in de agency theorie betreft de inrichting van de beloningsstructurir voor de agent.

In het HAM is oorspronkelijk gekozen voor vaste salarissen voor de betrokken geacademiseercle huisartsen (wage contract), ongeacht de prestatie. Toen bleek dat een belangrijk nadeel van deze beloningsvorm, namelijk het ontbreken van een "incenti. vel voor cle huisarts, door de huisartsen als zodanig erwaren werd, is onderzocht welke deeltaken op een andere manier beloond konden worden. Met name de meetbaarheid van de prestatie was hierbij van groot belang. De registratie van (geanonimiseerde) patiëntgegevens bleek een geschilkte deeltaak te zijn voor een aangepaste beloningswijze. Voor deze taak is dan ook een "prestatie-beloning" afgesproken, waarbij het aantal op een juiste wijze geincludeerde patienten bepalend is voor de uiteindelijke beloning. Er is hier dus geen sprake van een forcing contract, aangezien er in pincipe geen minimum prestatieniveau is vastgesteld.

Overigens geeft de bestudering van de economische organisatietheorieèn aanleiding tor een korte toevoeging op de in paragraat 3.5.3. gepresenteerde beloningssystemen van her HAM. Er wordt hier gesproken wan vier beloningssystemen, te weten:

- prestatie tegen salaris;

- prestatie tegen prestatie;

- prestatie tegen geld;

- Outputfinanciering

De eerste drie genoemde beloningen wekken de indruk gekoppeld te zijn an het te leveren prestatieniveau, hetgeen nadrukkelijk niet het geval is. Het is dan ook beter voortan te spreken van takkafhankelijke beloningssystemen; waarbij de uitoefening van een specifieke tak wordt gecompeneend met respectievelijk een vast salaris, een waannemer in de praktijk of een vaste (onkosten)vergoeding.

Bij outputfinanciering is er wel sprake van prestatiebeloning. 


\subsection{Samenvatting en conclusie}

In de literatuur worden veel theorieèn aangetroffen, die van toepassing kunnen zijn voor de ontwikkeling van huisartsgeneeskundige academiseringsmodellen. In hoofdstuk 2 is de literatuur beschreven zoals aangetroffen in voomamelijk de geneeskundige vakliteratuur, terwijl hoofdstuk 5 een onderbouwing biedt vanuit de organisatiekundige invalshoek.

Geconcludeerd mag worden dat de beschreven theorieën belangrijke informatie geven over de mogelijkheden van en valkuilen bij de ontwikkeling van academiseringsnetwerken. Daarbij biedt de ene theorie meer aanknopingspunten dan de andere. Een dilemma is gelegen in het hanteren van de verhouding tussen de twee partijen. Daar waar de ene partij (de universiteit) de financiële middelen inbrengt, bestaat er een bijna natuurlijke drang de academiseringsprocessen eenzijdig te gaan beheersen, hetgeen de stabiliteit van het netwerk niet ten goede komt. Ook in de theorieèn wordt dit dilemma aangetroffen.

De ervaring leert dat het streven naar inhoudelijke en bestuurlijke gelijkwaardigheid tussen universiteit en het geacademiseerde huisartsenveld de meeste garantie geeft voor inhoudelijk succes en stabiliteit van het academiseringsnetwerk. Hoofdstuk 6 en 7 gaan hierop dieper in en bieden hierover empirisch materiaal.

Sturing van het academiseringsproces met behulp van een "bestuursapparaat" bestaande uit universitair verantwoordelijken en (geacademiseercle) huisartsen en met erkenning van elkaars rol geeft een zekere waarborg voor het op professionele wijze hanteren van het beschreven dilemma.

Retrospectieve beschouwing van het Maastrichtse academiseringsmodel aan de hand van de organisatorische literatuur levert een vifftal relevante theorieën op. Deze theorieën geven elk op hun eigen wijze inzicht in het proces van de acadernisering van de huisartsgeneeskunde. Een samenvatting van deze theorieën wordt in schema 5.2 gegeven.

Elk van de theorieën gaat in op bepaalde onderdelen van samenwerkingsrelaties.

Mintzberg ${ }^{10}$ bespreekt de diverse typen van organisaties, de situationele factoren van die organisaties en de wijze waarop coördinatie plaatsvindt. Het positioneren van de universiteit aan de hand van de theorie van Mintzberg ${ }^{10}$ geeft belangrijke inzichten ook woor de inrichting van het academiseringsnetwerk.

Andere theorieën behandelen de wijze waarop partijen samenwerking vinden (interorganisationele samenwerking) en de redenen waarom partijen tot samenwerking besluiten. De netwerktheorie besteedt aandacht aan het "geraamte" van de samenwerkingsrelatie.

De transactiekostentbeorie en de agency-theorie tenslotte benadrukken de wijze waarop het transactie- of ruilproces optimaal kan plaatsvinden, hoe er toezicht kan zijn op de naleving van de afspraken en welke contractwormen in verschillende situaties gehanteerd kunnen worden.

Er is geen hiërarchie in deze theorieèn aanwezig; de ene is a priori niet belangrijker dan de ander.

Indien de theorieèn afgezet worden tegen het reeds gerealiseerde Huisarts- 


\subsection{Giteratuur}

1

Blanken $A J_{1}$ Oudkerk RH. Samen werkt het beter: en onderzoek narar de samenwerking tussen universiteifi ent huisartsen. Groningen : Faculteit Bedriffskunde, Rijkstiversiteir Groningen, 1988

2

Botter $\mathrm{CH}$. Industrie en organdsatie; en verkenningstocht. Kuwer/NIVE, 1970

3

Douma S, Schreuder He Fconomic approaches to organizations. Prentice Hall International Ltd. United Kingdom, 1992

4

Glls MR van, De organisate van onganisaties, M\&O Tijdschrift voor organisatiekunde en sociaal beleid 1978; 32: $9-31$

S

Godfroil A. Newerken van organisates; Strategieên, spelen, structuren. VUGA-Litgeverị. Den Haag. 1981 6

Groot "TLCM. Management wan unwersiteiten; een onderzoek nata de mogelijheden voor doelmatig en doeltreffend universitair bestuur. Wolters-Noordhoff. Groningen, 1988

7

Hendrikse GWJ. Coordineren en motiveren, een overzicht wan de economische onganisatietheorie. Academic service, economie en bedriffskinde. Schoonhoven, 1993

8

Keuning D, Eppink DJ. Management en organisatie: Theorie en toepassing. H. E. Stenfert Kroese BV. Leiden/Antwerpen, 1985

9

Krogt ThWPM van der, Vroom CW. Organisatie in beweging. Lemma bv. Utirecht, 1991

10

Mintaberg H. Organisatiestructuren. Prentice Hall-Academic Service. Schoonhoven 1994

11.

Muider yD. Acafemische werkplaas eerstelljns gezondheidszorg. Med Contact, 1982; 26: 761-3

12

Rappont van de Commissie Academisening Eerstelijnsgezondheidszorg en Ambulante Geestelijke Gezondheidszorg in Limburg. Mastricht: Rijksuniversiteit Limburg, 1983

13

Scapens RW. Management Accounting: A review of recent developments. McMillan Education Ltd. United Kingdom, 1987

14

Schienan C. Beheersing van bedijfsprocessen. H. E. Stenfert Kroese. Leiden, 1975

15

Wassenberg A. Netwerken: organisatie en strategie. Boom Meppel. Amsterdan, 1980 
16

Weick KE. Educational organizations as loosely coupled systems. Administratiwe Science Quarterly 1976: 1/19 17

Williamson OE. Markets and hierarchies: analysis and antitrust implications. Free Press. New York, 1975 18

Williamson OE. The economics of organization: the transaction cost approach. American Journal of sociology $1981 ; 548-77$

19

Zwwan AI van der. Netwerken: samenhang en samenwerking in de gezondheidszorg. In Maarse JAM, Murveeman IM (red). Beleid en beheer in de gezondheidszorg; Problemen, structuren, processen en effecten. Van Gorcum. Assen, 1990:411-25

20

NHG-standaarden voor de huisarts. Rutten GEHM, Thomas S (red). Bunge. Utrecht, 1993 


\section{HOOFDSTUK 6}

\section{ACADEMISERING VAN}

\section{DE HUISARTSGENEESKUNDE}

\section{Onderzoek naar de ontwikkeling van huisartsgeneeskundige academi- seringsnetwerken in Nederland; wat is het doel, de definitie en de kwantitatieve en kwalitatieve omschrijving van zo'n netwerk?}

R.J.J. Kocken

Hoofd Coordinatieburean Lerste Lin

Beheerder vakgroep huisiatsgeneeskunde

Rijksuniwersiteit Limburg

J.S. Meijer

F. Fi.M. Moms

P.E.L.M. Smeets-Rinkens

\author{
Unversitair docent wakgroep hutsartsgeneeskunde \\ Universileit van Amsterdan \\ Tevens linisirts te Ansterdan
}

Huisarts te Zwammerdam, verbonden an de vakgroep hüsartsgeneeskunde / Rijksuniwesiteir Leiden

Onderzoel6s-assistent vakgnoep huisarkgenesskunde Rijksuniversiteit Limburg

\section{Verantwoording}

Dit hoofdstuk beschrifft de resulkaten wan een landelijk onderzoek zoals dat door de projectgroep "Evalluatie Sumuleringsregeling Universitaire Husartspraktijken ${ }^{m}$ in opdrach en onder verantwoordelijkheid van de Begeleidingscommissie Academisering Eersteling Gezondheidszorg (BABG) werd uitgevoerd.

De belangrijkste resultaten van het onderzoek zijn gepulbliceerd in Med Contact $1992(47) ; 26 ; 811-4$.

\subsection{Inleiding}

De huisartsgeneeskunde in Nederland heeft zich de afgelopen decennia als wetenschappelijke discipline ontwikkeld. Het draggvak woor een dergelijke ontwikkeling. wordt niet alleen gevonden bij de universitaire huisartsgeneeskundige instituten, maar ook bij de praktizerende huisartsen "in het veld". Het is dan ook niet vreemd dat het begrip "Academisering van de huisartsgeneeskunde" steeds meer aandacht krijgt, als parallelle ontwikkeling naast de verdere uitbouw van academische ziekenhuizen. Ook vanuit het Ministerie van Welzijn Volksgezondheid en Cultuur (WVC) is er toenemende aandacht voor dit proces, hetgeen geleid heeft tot subsidiëring van een national project, genaamd de "Stimuleringsregeling Universitaire Huisartspraktijken". Onder begeleiding van de BAEG (Begeleidingscommissie Academisering Eerstelijns Gezond- 
heidszorg $1^{1,23,4,5}$ werd door een projectgroep gewerkt aan de theoretische onderbouwing en de praktische uitwerking en invoering van academische netwerken huisartsgeneeskunde. Onderdeel van de werkzaamheden van deze projectgroep was de ontwikkeling en de uitwoering van een landelijke enquête naar doel, definitie en omschrijving van deze academische netwerken. Zowel stafleden van vakgroepen huisartsgeneeskunde als (potentiële) huisartsen wan het netwerk werden ondervraagd.

Dit artikel beschrifft de belangrijkste bevindingen van dit onderzoek.

Doelstelling was de beschrijwing van de doelstellingen, de definitie en de kwalitatieve en kwantitatieve aspecten wan een geacademiseerd huisartsgeneeskundig netwerk.

De volgende vragen werden bestudeerd:

- Bestaan er verschillen in inzicht tussen de huisartsgeneeskundige universitaire vakgroepen en de praktizerende huisartsen inzake de noodzaak en de uitwerking wan een geacademiseerd netwerk?

- Hoe moet naar het oordeel van betrokkenen een dergelijk netwerk tot stand worden gebracht; hoe is de verhouding tussen de diverse partijen, wie voert de selectie van de deelnemende huisartsen uit en op basis van welke criteria gebeurt dit?

- Welke inhoudelijke activiteiten kunnen bij uitstek worden uitgevoerd in het kader van een geacademiseerd netwerk?

\subsection{Methode}

Het onderzoek werd uitgevoerd door middel van een schriftelijke enquête, bestaande uit viagen naar zowel de infrastructuur als de inhoud van een geacademiseerd netwerk. Het merendeel van de gestelde vragen kon worden beantwoord in de ja/neen vorm, terwijl er bij een beperkt aantal vragen naar de voorkeur voor één of meer antwoordmogelijkheden werd gevraagd. Aangezien het de bedoeling was een duidelijk beeld te kriigen over de opvattingen van richtinggevende personen onder zowel stafmedewerkers als praktizerende huisartsen werd aan elk van de 8 nederlandse vakgroepen huisartsgeneeskunde gevraagd de schriftelijke enquête te verspreiden onder 5 sleutelfiguren in de staf (bij voorkeur de hooglerar-voorzitter, coördinator huisartsopleiding, coördinator onderwijs, coördinator onderzoek en de beheerder) en 5 daadwerkelijke dan wel (bij vakgroepen die nog geen netwerk hadden) potentiële netwerkhuisartsen. De selectie van de huisartsen vond plaats door het staflid van de betreffende vakgroep huisartsgeneeskunde, belast met de samenwerking van de vakgroep met het praktizerende veld. Op deze wijze werd de enquete verspreid over in totaal 80 personen ( 40 stafleden en 40 praktizerende huisartsen).

De statistische analyse van de verschillen tussen de staheden en huisartsen vond plaats door middel van de chikwadraat-toets voor onafhankelijke steekproeven in geval van categorische variabelen. Er werd telkens tweezijdig getoetst, met een significantie-
drempel van 0.05 . 


\subsection{Resultaten}

\subsubsection{Respons}

De enquete werd door in totaal 59 participanten teruggestuurd, hetgeen een totalrespons van $74 \%$ betekent. Van de (potentiële) netwerkartsen reageerden in totaal 25 geenquetteerden $(63 \%)$, terwijl de stafleden een respons gaven van $85 \%(n=34)$.

\subsubsection{Omschrijving academisering}

Met de door de projectgroep gegeven omschrijving van academisering (de gestructureerde/geïnstitutionaliseerde samenwerking tussen universiteit en huisartspraktijken, waarbinnen onderling samenhangende en vooraf overeengekomen activiteiten plaatsvinden ten behoeve van de integratie van onderwijs, onderzoek en patientenzorg) was een ruime meerderheid het eens $(77 \%)$.

Alhoewel de definitie van academisering huisartsgeneeskunde op hoofdlinen wordt ondersteund, geven vele respondenten aan de definitie te willen uitbreiden. Met hame over de noodzaak tot integratie van patiëntenzorg, onderzoek en onderwijs worden vragen gesteld. In ieder geval wordt aan de definitie toegevoegd "met behoud van ieclers verantwoordelijkheid".

\subsubsection{Infrastructuur academisering}

\section{Positie der partijen}

In elk netwerkmodel is het belangrijk te bepalen hoe de diverse deelnemers in het netwerk zich tot elkaar verhouden. In het geacademiseerde netwerk huisartsgeneeskunde gaat het dan primair om de verhouding tussen de universitaire vakgroepen en de deelnemende huisartsen.

Wat betreft de positie van deze 2 partijen in her netwerk bestaat zowel bij de huisartsen als bij de stafmedewerkers een voorkeur voor een gelijkwaardige positie.

Opvallend is in dit verband dat $24 \%$ van de stafmedewerkers van mening is dat de vakgroep/universiteit centraal zou moeten staan, terwijl slechts $4 \%$ varn de huisartsen vindt dat de huisartsgroep zelf centraal zou moeten staan ( $p=0.04)$.

Met betrekking tot de wijze waarop deze gelijkwaardigheid gerealiseerd zou kunnen worden bestaat een lichte voorkeur voor de aanstelling van de netwerk-huisartsen bij de universiteit. Echter ook de andere opties scoren hoog. Het geven van een vertegenwoordigerszetel aan de huisarts in het bestuur van de vakgroep scoort 34\%, terwijl de stichtingsvorm in $37 \%$ van de gevallen als ideaal beschouwd wordt.

\section{Selectie en selectie-criteria (Tabel 6.1)}

Over de vraag wie de selectie van de in het netwerk deelnemende huisartsen mag uitvoeren, bestaat nauwelijks verschil van mening. Van de ondervraagden vindt $66 \%$ dat een delegatie van de huisartsengroep en de vakgroep dat zou moeten doen, terwijl 
slechts 33\% van mening is dat de vakgroep de selectie geheel zou kunnen witwoeren Selectie doot een onafhankelik bureau is geen gewardeerde optie.

Als belangrijkste selectie-items worden door beide partijen genoemd een aantoonbare motivatie van de huisarts en reeds eerder opgedane ervaring met wetenschappelike taken. Als anvullend selectie-item werd door een beperkt aantal ondervraagden (bereidheid tot) attomatisering van de praktijk genoend.

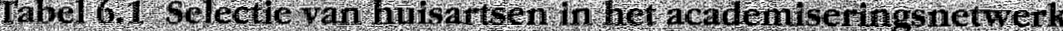

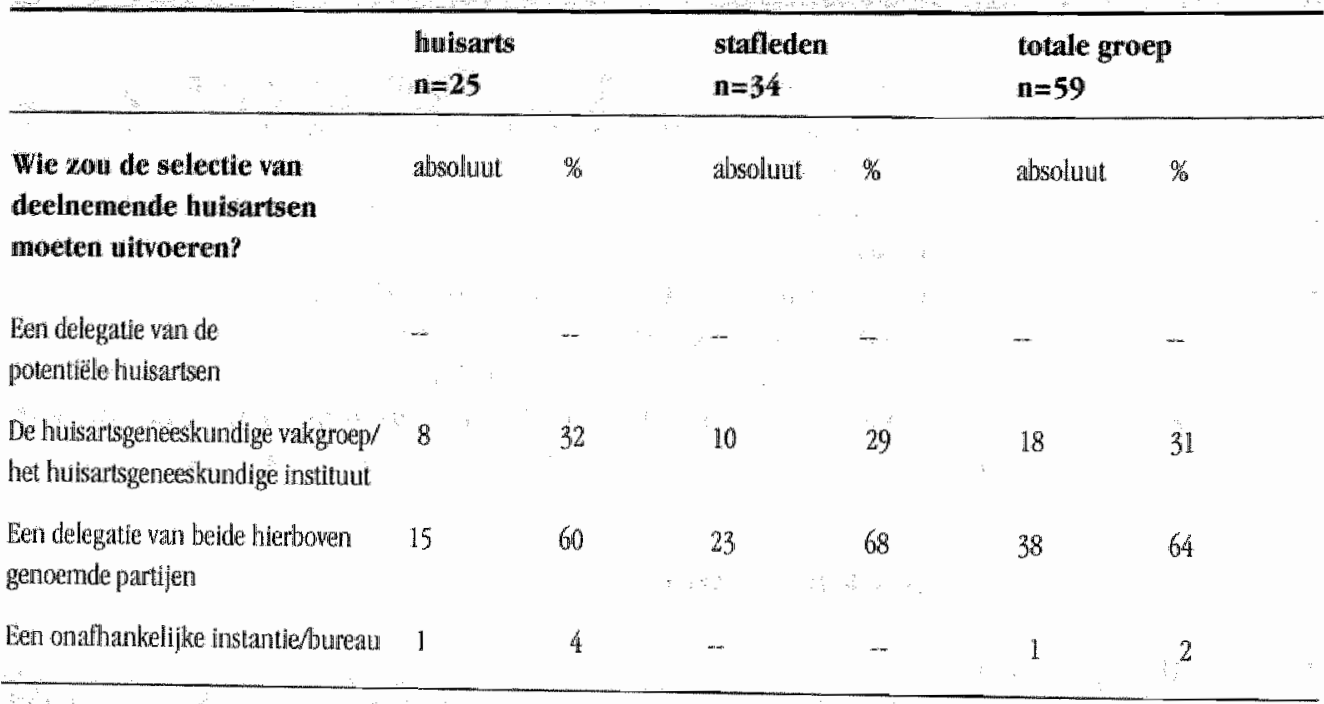

\section{Welke selectie-criteria zijn belangrijk?}

\begin{tabular}{|c|c|c|c|c|c|}
\hline $\begin{array}{l}\text { De geografische spreiding van het } \\
\text { trotale netwerk }\end{array}$ & 12 & 48 & 16 & 47 & 28 \\
\hline $\begin{array}{l}\text { Populatide-onvang en samenstelling } \\
\text { van de popiullitie wan de praktijk(en) }\end{array}$ & 10 & 40 & 16 & 47 & 26 \\
\hline $\begin{array}{l}\text { De antoonbare motivatie van } \\
\text { de huisarts }\end{array}$ & 19 & 76 & 30 & 88 & 49 \\
\hline $\begin{array}{l}\text { De antoonbare eryaring met } \\
\text { wetenschappelijke takes, cpleiding } \\
\text { en patientenzory }\end{array}$ & 17 & 68 & 26 & & 43 \\
\hline
\end{tabular}

(Geen win de verschillen in deze abel is statsisch significan)

Dat er an de deelnemende praktijken eisen moeten worden gesteld is voor vrijwel iedereen evident $(92 \%)$.

Het is echter ingewikkeld een pakket van zogenaamde ingangseisen, te stellen aan de potentiẻle geacademiseerde huisarts, te formuleren.

Toch blijkt er vrij brede steun voor de in tabel 6.2 beschreven ingangseisen. 


\section{lingangseis}

Bereidheid tot automatisering wan

de huissirtspraktijk

Werken volgens basistakenpakket

Bereidheid tot onderlinge toetsing huisartsen $(n=25)$

stiffeden $(\mathrm{n}=34)$

totale groep $(\mathrm{n}=59)$

(Geen wan de werschillen in deze tabet is statistisch signficant)

\section{Argumentatie om deel te nemen aan een netwerk}

Ook over de argumentatie van de huisarts om deel te nemen aan een geacademiseerd netwerk bestaat een eenduidig beeld. De huisarts zou moeten deelnemen vanwege een wetenschappelijke interesse ( $88 \%$ ), affiniteit met de taken van een dergelijk netwerk $(76 \%)$ en de te verwachten verbetering van de eigen zorgverlening $(83 \%)$. Tabel 6.3 beschrijft de belangrijkste argumenten van de huisartsen om deel te nemen aan een academiseringsnetwerk.

De universiteit zou aan een dergelijk netwerk moeten participeren om de inzet van praktizerende huisartsen in onderwijs en onderzoek (verder) te structureren.

\begin{tabular}{|c|c|c|c|c|c|c|}
\hline \multirow[b]{2}{*}{ Argument } & \multicolumn{2}{|c|}{$\begin{array}{l}\text { Score van } \\
\text { de huilsartsen } \\
\mathrm{n}=25\end{array}$} & \multicolumn{2}{|c|}{$\begin{array}{l}\text { Score van } \\
\text { de stafleden } \\
n=34\end{array}$} & \multicolumn{2}{|c|}{$\begin{array}{l}\text { Score van } \\
\text { de totalle groep } \\
=59\end{array}$} \\
\hline & absoluut & $\%$ & absoluut & 棉 & absoluut & $\%$ \\
\hline Wetenschapplilike interesse & 22 & 88 & 30 & 88 & 52 & 88 \\
\hline Professionele curriere & 8 & 32 & 16 & 47 & 24 & 41 \\
\hline $\begin{array}{l}\text { Affin teit tot het kakenpakket } \\
\text { wat de geacademiseerde huisants }\end{array}$ & 16 & 64 & 29 & 85 & 45 & 76 \\
\hline $\begin{array}{l}\text { Ideallisme (am de discipline huis- } \\
\text { antsgeneeskunde werder te }\end{array}$ & & & & & & \\
\hline Ontwikkelen) & 12 & 48 & 17 & 50 & 29 & 49 \\
\hline Geldel ijke vergoeding & 4 & 16 & 11 & 32 & 15 & 25 \\
\hline $\begin{array}{l}\text { Werbetering van de eigen } \\
\text { worgvertenting }\end{array}$ & 22 & 88 & 27 & 77 & 49 & 83 \\
\hline
\end{tabular}




\section{Contracten}

93\% van de respondenten is van mening dat de verhouding tussen de huisarts en de universiteit in een contract nader geformaliseerd zou moeten worden, waarbij de deelnemende huisartspraktijken geheel zelfstandig moeten kunnen blijven functioneren. Slechts een minderheid van de ondervraagden is van mening dat de praktijken gedeettelijk dan wel geheel eigendom wan de universiteit zouden moeten zijn/worden.

De meest gewenste wijze van vergoeding bestaat uit een combinatie van ruil van mens kracht tegen menskracht (de praktizerende huisarts vervult taken voor het universitaite instituut, terwijl het instituut een medewerker uitleent voor de dagelijkse patiëntenzorg: en een geldelijke vergoeding $(64 \%)$.

De respondenten hebben een voorkeur voor een contractduur van niet langer dan 5 far. Opvallend in dit verband is het feit dat de huisartsen meer neigen naar langer lopende overeenkomsten, terwijl de stafleden een voorzichtiger beleid voorstaan. Het geacademiseerde huisartsnetwerk zou bij voorkeur tussen de 5 en 15 praktijken moeten onvatten, waarbij elke praktijk zich zou moeten kunnen concentreren op één van de hoofdtaken onderwijs, onderzoek of innovatie van patiëntenzorg.

\subsubsection{Opleiding}

Overwogen moet worden in hoeverre huisartsen bij deelname aan een geacademiseerd netwerk aanvullend opgeleid moeten worden. Ook dienaangaande werden in deze enquête vragen gesteld. Volgens de respondenten moeten op de volgende gebieden aanvullende opleidingen georganiseerd worden:

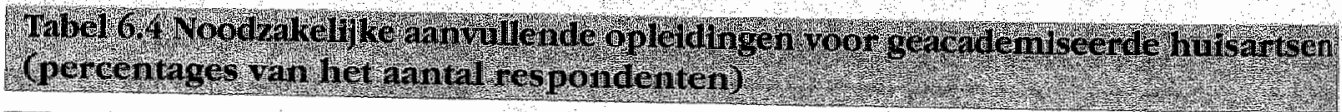

\section{Type opleidling}

Automatlisering / registraije

Wetenschappetijk vorning

Didacliek

\begin{abstract}
huisartsen $(\mathrm{n}=25)$
\end{abstract}
68

68

76 stafleden $(\mathrm{n}=34)$

82

82

82 totale groep $(n=59)$

76

76

79

(Geen wan de verschllen in deze tabel is significani)

\subsubsection{Knelpunten}

Als centrale knelpunten in de totstandbrenging van een geacademiseerd huisartsnetwerk worden het tijdsprobleem van de huisarts en het gebrek aan afstemming van de honoreringsstructuren van de gevestigde en de universitair werkende huisarts genoend. Opvallend is bovendien dat ook de positie van de vakgroepen huisartsgeneeskunde binnen de diverse faculteiten in $42 \%$ van de gevallen nog steeds als mogelijk knelpunt
genoemd wordt.

(Tabel 6.5.) 


\begin{tabular}{|c|c|c|c|c|c|c|}
\hline \multirow[b]{2}{*}{ Geconstateerde knelpunt } & \multicolumn{2}{|c|}{ Score huisarts $n=25$} & \multicolumn{2}{|c|}{ Score stafleden $\mathrm{n}=34$} & \multicolumn{2}{|c|}{ Score totale groep $n=5$} \\
\hline & ahsoluut & $\%$ & absoluut & $\%$ & absolunt & $\%$ \\
\hline $\begin{array}{l}\text { De inrichting van de gezondheids- } \\
\text { worg rnadki de opbouw yan deze } \\
\text { netwerken bij poorbaat kansloos }\end{array}$ & 2 & 8 & 3 & 9 & 5 & 8 \\
\hline $\begin{array}{l}\text { De huisarts heeft onvoldoende tijd } \\
\text { en gelegenheid om de academische } \\
\text { taken wit te kunnen voeren }\end{array}$ & 16 & 64 & 14 & 41 & 30 & 51 \\
\hline $\begin{array}{l}\text { De honoretingssiructunei } \\
\text { (uniwersiteit wersus huisarts) zijn } \\
\text { onvoldoende op elkaar afgestemd }\end{array}$ & 14 & 56 & 20 & 59 & 34 & 58 \\
\hline $\begin{array}{l}\text { De pusitie wan de vakgroep } \\
\text { huisartsgeneeskunde in de } \\
\text { faculteivaniversileit }\end{array}$ & 9 & 36 & 10 & 29 & 19 & 32 \\
\hline
\end{tabular}

\subsubsection{Inhoudelijke aspecten}

\section{Onderwijs}

Alle in de enquête genoemde academische taken in het kader van patièntenzorg scoren hoog. Een geacademiseerde praktijk is bij uitstek geschikt voor demonstraties, als modelpraktijk en voor het gebruik van patiëntengegevens.

In het kader van het kennismakingsonderwijs in het basiscurriculum lijkt de geacademiseerde praktijk zeer geschikt ten behoeve van het maken van vicleo-opnames van het spreekuur, meeloopdagen, oriëntatie in de eerste lijn en thuiszorg, demonstraties van avromatisering en demonstraties van patienten op de colleges.

Wat betreft het vaardigheidsonderwijs is de praktijk te gebruiken voor de co-schappen, voor keuze-onderwijs en ten behoeve wan het tranen en eventueel toetsen van vaardigheden voor het artsexamen.

Wat betreft de huisartsopleiding kan de geacademiseende praktijk met name ingezet worden voor video-toepassingen (contact ussen patient-husarts in opleiding (HAJO).

\section{Onderzoek}

In het kader van het wetenschappelijk onderzoek dienen de praktijken volgens de respondenten bij voorkeur te participeren aan de in tabel 6.6 beschreven onderzoeksterreinen. 


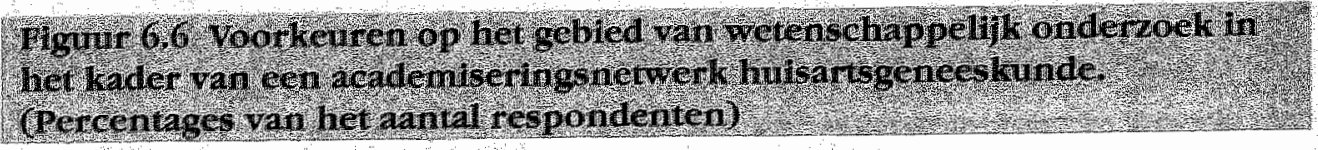

\begin{tabular}{|c|c|c|c|}
\hline Onderzoek op het terrein van: & totale groep $(n=59)$ & huisartsen ( $(\mathrm{n}=25)$ & stafleden ( $\mathbf{n = 3 4}$ ) \\
\hline Kwaliteltsbevordering En - bewaking & 69 & 76 & 64 \\
\hline Protocollaire werkwizze / standaarden & 688 & 72 & 64 \\
\hline Registratie van klachten en verrichtingen & 59 & 68 & 55 \\
\hline Went|pingen & 58 & 72 & 45 \\
\hline Huisartsgeneeskundig handeien & 47 & 52 & 46 \\
\hline
\end{tabular}

\subsection{Verschillen tussen stafleden en praktizerende huisartsen.}

In zijn algemeenheid kan geconcludeend worden dat de praktizerende huisartsen en de universitair werkende huisartsen overeenkomstige meningen hebben over de noodzaak, het doel en de inhoud van het academiseringsproces. Significant verschillend wordt er gedacht over 2 zaken:

- hoewel een meerderheid van zowel praktizerende huisartsen als stafleden van mening is dat beide partijen in een geacademiseerd netwerk een gelijkwaardige positie zouden moeten hebben, is de mate van ondersteuning voor deze gelikwaardigheid significant verschillend. Met name stafleden geven in redelijke omvang steun an een andere verhouding tussen beide partijen, namelijk die waarbij de universiteit centraal staat $(\mathrm{p}=0.04)$.

- de stalleden vinden "de motivatie van de deelnemende huisarts om deel te nemen aan een netwerk" als ingangseis voor opname in een academiseringsnetwerk signim ficant vaker belangrijk dan de huisartsen zelf $(p=0.04)$.

\subsection{Beschouwing}

Het onderzock kent een aantal beperkingen; de belangrijkste betreft de grote verschillen tussen de diverse universitaire vakgroepen op het gebied van onderwijs-, onderzoek - en academiseringsbeleid. Sommige vakgroepen hadden reeds de beschiklking over samenwerkingsnetwerken, terwijl andere huisartsgeneeskundige groepen nog in de planfase verkeerden.

Ook het aangeboden onderwijs en de gekozen onderzoeksthematieken verschillen sterk, hetgeen de uotstandkoming van één landelijke enquête bemoeilijkt heeft. Toch geven de uitkomsten van het onderzoek inzicht in een aantal infrastructurele en inhoudelijke componenten van een academiseringsnetwerk huisartsgeneeskunde.

Ten aanzien van de ondervragden het volgende. De onderzoekers hebben gekozen voor een onderzoekspopulatie bestaande uit claadwerkelijke dan wel potentiële net- 
werkhuisartsen. Reden voor deze keuze was de bif deze huisartsen aanwezige voor kennis over het fenomeen academisering. Het gevaar is uiteraard dat een zekere selectiebias optreedt, aangezien het doorgaans husartsen betreft die reeds langere tijd met grote motivatie werkzaamheden werrichten voon en in samenwerking met de universitaire vakgroepen husartsgeneeskunde. Een dergelije selectievertekening is echter ook mogelijk wat betreft de benaderde stafleden, die geacht worden een sleutelfunctie met betrekking tot academisering te vervullen. De vergelijking tussen deze min of meer richtingbepalende groeperingen is daarom eerder meer dan minder relevant.

De door de projectgroep gegeven omschrijving van academisering (de gestructureerde/geinstitutionaliseende samenwerking tussen universiteit en huisartspraktijken, waarbinnen onderling samenhangende en vooraf overeengekomen activileiten platsvinden ten behoeve van de integratie van onderwijs, onderzoek en patientenzorg) wordr onderschreven. Van belang wordt gevonden aan de definitie toe te voegen dat de samenwerking plaatsvindt met behoud van de eigen verantwoordelijkheden; de huisarts voor de patiëntenzorg en de vakgroep voor onderwijs, onderzoek en huisartsopleiding.

Het meest gewenste huisartsgeneeskundig academiseringsnetwerk bestaat uit 5 - 15 prakdijken die contractueel voor 5 - 10 jaar aan de universiteit verbonden zijn. Er dient een gelijkwaardige positie tussen huisarts en universiteit in het netwerk bereikt te worden enerzijds door de huisarts aan te stellen bij de universiteit, anderzijds door de geacademiseerde huisartsen een vertegenwoordigingszetel in het bestuur van de vakgroep te geven.

De selectie van de deelnemende praktijken vindt bij voorkeur plaats door een delegatie van staf en huisartsen, waarbij motivatie en reeds opgedane ervaring met weten schappelijke taken belangrijk worden gevonden. Beide groeperingen zijn van mening dat de huisartspraktijk geautomatiseerd moet zijn dan wel worden en dat de huisartsen moeten werken volgens het basistakenpakket en een bereidheid tot onderlinge toetsing moeten hebber.

De respondenten zijn van mening dat de huisarts gedifferentieerd moet worden ingezet woor of onderwijs of onderzoek of patiéntenzorgontwikkeling. Inzet van de deelnemende huisarts op meerdere inhoudelijke terreinen leidt waarschijnlijk tot teveel versnippering. De beschikbare tijd van de huisarts wordt als problem ervaren.

De geacademiseerde praktijk lijkt met name geschikt voor clemonstraties, orientaties, wa ardighedenonderwijs en automatisering/registraties. Het onderzoek zou zich moeten richten op het werken volgens protocollen/standaarden en onderzoek op het gebied wan de kwaliteitsbewaking. De gedefinieerde onderzoekscategorieen bleken achteraf niet compleet; een categorie 'patientgebonden onderzoek' (de waarde van diagnostische tests en therapieèn, prognoses en oorzaken van ziekte) ontbrak in het meetinstrument. Het is echter waarschijnlijk dat de respondenten dit type onderzoek hebben opgevat als onderdeel van de categorie "huisartsgeneeskundig handelen".

Beide respondentgroepen zijn van mening dat de aan het netwerk deelnemende huisartsen op specifieke terreinen verder geschoold dienen te worden. Deze scholing lijkt het meest gewenst op de terreinen didactiek, wetenschappelijke vorming (methodologie/statistiek) en automatisering, mede ten behoeve van medische werslaglegging en registratie-activiteiten. 
Uit de resultaten van dit onderzoek blijkt dat er redelijke overeenstemming bestaat tussen betrokken huisartsen en stafleden over het doel, de definitie en de inhoudelitke omschijving van een academiseringsnetwerk.

In een vervolgonderzoek zou meer aandacht besteed kunnen worden aan de stand van zaken en het draagvlak op het gebied van de nederlandse huisartsgeneeskundige academiseringsnetwerken.

\subsection{Literaturur}

1

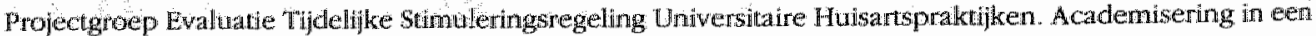
netwerk, Verblag wan een wagenlijstonderzoek. Ansterdam: Instuut wor Huisarsgeneeskunde, Uniwersiteft wan Arristerdam, 1990

2

Projectgroep twaluarie thdelike Stmuleringsegeling Universitaire Huisartspraktijen. Academisering in zichi. Vistes op de doelstellingen voo een newwerk. Amsterdam: Instituut woor Huisartsgeneeskunde, Universiteill van Anusterdam, 1990

3

Projectgoep Evaluatie Tijdelike Stmuleringsregeling Univensitaine Huisartsprakrijken. Academisering in die praktilk. Thssentidse tapportage van de projectgroep evaluatie van de Tijdelijke Stimuleringsregeling Universitaine Huisantspraktiken. Amsterdam: Instituut voor Huisartsgeneeskunde, Universiteit van Amsterdam, 1990

4

Projectgroep Evaluatie Tijdetijke Stimuleringsregeling Universiaire Huisartspraktijken. Academisering in de huisartspaktiflk. Eindrapport var de Projectgroep Haluatie van de Tijdelifke stimuleringsregeling Universitate Huisartspraktiken, Amsterdam: Institukt woor Huisartsgeneeskunde Universiteit van Amsterdam, 1990

5

Begeleidingscommissie Academulsering Lerstelins Geneeskunde. Ontwikkelngsplan academisering huisarts geneeskundc. BAEG 150,1991 


\title{
ONDERZOEK NAAR INHOUD, PROCES EN
}

\section{UITKOMST VAN DE ACADEMISERING VAN}

\section{DE HUISARTSGENEESKUNDE AAN \\ DE RIJKSUNIVERSITEIT LIMBURG}

\author{
R.J.Kocken \\ Beheerder wakgroep husartsgeneeskunde \\ Hoofd Coordinatiebureau Eerste Lijn \\ M. Muris \\ (Geacademiseerd) huisans \\ Gezondheidscentrum Neerbeek \\ H.F. I.M. Crebolder \\ Hoogleraar huisartsgenees kunde \\ J.A. Knottnerins \\ Hoogleraar huisartsgeneestunde \\ PIE.L.M. Smeets-Rünkens \\ Onderzoeksassistente vakgroep huisartsgeneeskunde \\ f. Blommeart \\ Uniwersitaiir docent valkgroep Berichtgeving \\ Faculteit der Economische Wetenschappen
}

\section{Verantwoording}

Artikel geaccepleend woor publikatie in Medisch Contact.

\section{Samenvatting}

De Rijsuniversiteit Limburg te Mastricht besteedt veel aandacht aan de ontwikkelingen op het gebied van de extramurale gezondheidszorg. Een structurele relatie met de zorgverleners is daarvoor onontbeerlijk; naast een academisch ziekenhuis ${ }^{15-20}$ is een netwerk van geacademiseerde huisantspraktijken opgebouwd. Dit artikel beschrijft een evaluatie-studie middels een schriftelijke enquête onder 29 vaste stafleden van de vakgroep huisartsgeneeskunde en 55 geacademiseerde huisartsen. Onderzocht werden aspecten van academisering, zoals doelstelling en definitie, optimale omvang van het netwerk en contract-technische relatie tussen de beide partijen, selectie van praktiken, kwaliteitstoetsing, de mogelijke aanpassing van het praktijkmanagement en de invloed van deelname an het academiseringsnetwerk op de uitoefening van de patientenzorg. De resultaten wijzen erop dat academisering niet alleen van belang is om lhuisartsen op structurele basis te betrekken bij het universitaire onderwijs en onderzoek, maar ook voordelen voor de huisartsen zelf oplevert. De geacademiseerde huisarts is van oordeel zijn vak beter te kunnen uitoefenen en door de deelname aan het academiseringsnetwerk met nieuwe elementen in aanraking te komen. Deelname aan academisering vergt aanpassingen, maar de voordelen voor de huisarts lijken op te wegen tegen de (geringe) nadelige effecten, zoals cle noodzaak tot aanpassing van het praktipkmanagement. 


\subsection{Inleiding}

De Rijksuniversiteit Imburg te Mastricht heeft vanaf haar oprichting aandach geschonken aan de extramurale gezondheidszorg in het algemeen en de huisartsge neeskundige zorg in het bijzonder $1,2,9-14$.

Het lag dan ook in de rede dat de faculteit der geneeskunde van deze universiteit wan overheidswege gevragd werd de eerstelins-profilering in hat activiteitenpatroon special tot uiting te laten komen. Naast de ontwikkeling en uitbouw van een academisch ziekenhuis zouden in dit kader ook extramurale instellingen geacademiseerd moeten worden, bij voorkeur Regionale Instituten woor de Ambulante Geestelijke Gezondheidszorg (RIGG) en huisartspraktijken. Met 'academisering van huisartspraktijken' worct in dit verband bedoeld "de gestructureerde samenwerking tussen de universiteit en regionale huisartspraktiken, waarbinnen onderling samenhangende en vooraf contractueed) overeengekomen activiteiten platsvinden ten behoeve van de uitvoering en de integratie van huisartsgeneeskundig onderwijs, onderzoek en patiënten$2 \operatorname{org}^{3}, 4,5,6,7,8$. In de periode vanaf $1986 \mathrm{kreeg}$ de academisering van de hulsartsgeneeskunde vanuit de Rijksuniversiteit Limburg concreet gestalte in de vorm van contracten tussen de unversiteit en 83 huisartsen, werkzam in 30 praktijken. Deze huisartsen verrichten werkzaamheden op het gebied van wetenschappelijk (huisartsgeneeskundig) onderwijs, onderzoek, de huisartsopleiding en gezondheidszorgontwikkeling. De contracten zijn in principe voor onbepaalde tijd afgesloten, waarbij jaarlijks in de vorm van een inhoudelijk werkplan de concrete taakinvulling wordt overeengekomen. Vijf jaar na de start lijkt het zinvol deze ontwikkeling te evalueren. In het onderhavige onderzoek werd nagegaan hoe de diverse stafleden en de geacademiseerde huisatsen de inlhoud, het proces en de uitkomst van de academisering huis-

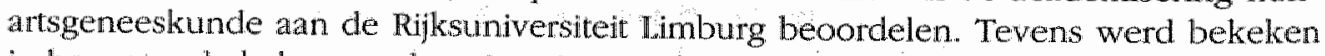
in hoeverre de leden van de universitaire vakgroep (de stafleden) anders denken over onderdelen van academisering dan het veld (de huisartsen). Bij deze laatste groep werd bovendien gevraagd naar de persoonhjke motivatie van de huisarts om deel te nemen aan academisering, de mogelijke spanning tussen academische taken en de patièntenzorg en naar enkele algemene, huisarts gebonden onderwerpen.

\subsection{Methode en populatie}

Het onderzoek werd verricht middels een schtiftelijke enquête, die verspreid werd onder 29 (vaste) stafleden en 55 geacademiseerde huisartsen. De overige geacademiseerde huisartsen werden niet onderviaagd, omdat zij pas sinds kort deel uitmaken van het academiseringsnetwerk. De data-verzameling werd gestant met het versturen van een aanbiedingsbrief, het enquete-formulier en een antwoondenveloppe. De gegevens
werden anoniem verzameld.

Zowel de huisartsen als de stafleden werd gevraagd nat hun mening over de volgen-
de items:

- de definitie van 'academisering' - infrastructurele zaken als de ideale omvang van het netwerk en de contract-techni-
sche relatie tussen beide partijen

- selectie-criteria en te stellen ingangseisen

- kwaliteitstoetsing en opleiding in het kader van academisering 
Stafleden en huisartsen werden verzocht om binnen twee weken na het versturen van de enquête te responderen. Er werd geen herinnering verzonden.

Bij de ontwikkeling van het meetinstrument werd gebruik gemaakt van de landelike enquete, zoals die in 1989 door de Begeleidingscommissie Academisening Huisartsgeneeskunde (BAEG) werd opgesteld $3-8$.

De vragen konden beantwoord worden in de volgende categorieen: volledig oneens, oneens, noch oneens noch eens, mee eens tot volledig mee eens. Deze categorieün werden in de analyse herleid tot een 5-punts score, warbij de categorie "wolledig mee eens" 5 punten kreeg.

De statistische analyse van de verschillen tussen beide groepen vond plaats door middel wan de chikwadraat toets voor onafhankelijke steekproeven in geval van categorsche variabelen en met behulp van de T-toets in geval van numerieke variabelen. Er werd tweezijdig getoetst; met een significantiedrempel van 0.05 .

Indien er scores in de tekst worden vermeld betreft het respectievelijk de gemiddelde score van de huisartsgroep en de gemiddelde score van de groep stafleden, war relevant gevolgd door de $\mathrm{p}$-waarde. Om praktische reden zijn niet steeds alle resultaten in tabelvorm weergegeven.

\subsection{Resultaten}

\section{* Respons}

Van de totalle onderzoekspopulatie van 84 haisartsen/stafleden respondeerde $65 \%$; drie respondenten gaven aan onvoldoende op de hoogte te zijn van het academiseringsproces en stuurden een leeg formulier retour. De bruikbare respons was in beide groepen even hoog, overeenkomend met 34 huisarts-respondenten $(62 \%)$ en 18 stafrespondenten (eveneens 62\%).

\section{* Omschrijving van academisering}

De volgende definitie van academisering werd aan de onderzoekspopulatie voorgelegd: onder academisering wordt verstaan de gestructureerde/geinstitutionaliseerde samenwerking tussen universiteit en huisartspraktijken, warbinnen onderling samenhangende en vooraf overeengekomen activiteiten plaatsvinden ten behoeve van de integratio van wetenschappelijk onderwijs en onderzoek en patiëntenzorg. Hiervor is een infrastructuur nodig, die een academiseringsnetwerk genoemd zou kunnen worden $4,5,6,7$,

Zowel de huisartsen als de stafleden zijn het in de regel met deze definitie eens (gemiddelde scores respectievelijk 3.8 en $3.6 ;$ standaarddeviaties 0.76 en 0.90 ).

Wel vermelden veel respondenten te willen streven naar een meer toegankelijke en gebruikerswriendelijke definitie.

* Verhouding tussen de partijen (universiteit en huisartsen) (tabel 7.1)

De geacademiseerde huisartsen zijn overwegend van mening dat de beide partijen in het academiseringsnetwerk (de huisarts en de universitaire vakgroep) een gelijkwaardige positie zouden moeten hebben (4.0). De stafleden nemen een middenpositie in; ze zijn het noch eens, noch oneens met de noodzaak wan een gelijkwaardige positie 
(3.2). Het verschil tussen huisartsen en stafleden is significant $(p=0.01)$. In het huidige netwerk wordt de positie van de vakgroep nog te centraal gevonden, met name door de geacademiseerde huisartsen. Oorspronkelijk bestond de gedachte dat deze gelijkwaardigheid het beste gerealiseerd kon worden door het verlenen van een universitaire aanstelling aan de geacademiseerde huisarts. Deze gedachte wordt door beide onderzoekgroepen niet onderschreven.

\section{* Selectie en selectie-criteria}

Aangezien een groter aantal huisartsen geinteresseerd is in participatie aan een academiserings-netwerk huisartsgeneeskunde dan de organisatorische en financiële mogelijkheden toelaten moet een selectie-mechanisme beschikbaar zijn.

Het blijkt dat beide partijen een voorkeur hebben voor een selectie door een delegatie, bestaandle uit vakgroepmedewerkers en huisartsen (4). Selectie door een onafhankelijke instantie wordt afgewezen. De belangrijkste selectie-criteria zijn volgens beide partijen de aanwezige motivatie van de potentiële geacademiseerde huisarts $(4.7 ; 4.9)$ en de aantoonbare ervaring met wetenschappelijke taken, de huisartsopleiding en/of de patiëntenzorg $(3.6 ; 4.0)$

Verder wordt door beide groepen aangegeven dat er gestreefd moet worden naar een goede geografische spreiding binnen de universitaire regio en naar voldoende variatie aan praktijkwormen (solo, associatie en dergelijke).

\section{Tabel 7 postie van de partign (vakgroep en hilsamsen) elkaa:}

\begin{tabular}{|c|c|c|c|c|c|}
\hline $\begin{array}{l}\text { POSITIE VAN DE PARTUEN } \\
\text { IN HET NETWERK }\end{array}$ & $\begin{array}{l}\text { Huisarts } \\
\text { Gem. Score } \\
\mathbf{n}=\mathbf{3 4}\end{array}$ & $\begin{array}{l}\text { Standalard- } \\
\text { devilatie }\end{array}$ & $\begin{array}{l}\text { Staf-lleden } \\
\text { Gem. Score } \\
\mathbf{n = 1 8}\end{array}$ & $\begin{array}{l}\text { Standaard- } \\
\text { deviatie }\end{array}$ & P - waarde \\
\hline $\begin{array}{l}\text { In cen academiseringsnetwerk } \\
\text { zouden de posities wan beidle } \\
\text { partijen (de hursartspraktijk en } \\
\text { de universiteíl) gelijkwasardig } \\
\text { moeten zijn }\end{array}$ & 4.0 & 1.0 & 3.2 & 1.2 & 0.01 \\
\hline $\begin{array}{l}\text { In het Maastrichtse netwerk } \\
\text { is de positie van de wakgroep } \\
\text { nog steods te centrat }\end{array}$ & 3.6 & 0.8 & 2.6 & 0.8 & $<0.01$ \\
\hline $\begin{array}{l}\text { Doordat de gencademiseerde } \\
\text { huisarts een aanstefling heef }\end{array}$ & 2.5 & 1.10 & 2.5 & 1.0 & 0.99 \\
\hline
\end{tabular}

bij de universitaire vakgroep

Huisartsgeneeskunde is gelijkwanrdigheid en betrokkenheid gewarborgd

Genuldelde scones op een uifpuntschaal, earierrend van I - in bet gebeed niw mee ens tot 5 - tolledig thee eens 


\section{* Aanvullende eisen}

Er bestaat overeenstemming tussen de staf van de vakgroep en het huisartsenveld over deze eisen. We vermelden daarom wat dit betreft alleen de gemiddelde scores van de groep respondenten als geheel. In volgorde van belangrijkheid moet de geacademiseerde huisarts volgens de respondenten bereid zijn tot onderlinge toetsing (4.3), de praktijk moet geautomatiseerd zijn (4.3), de huisarts moet werken conform het basistakenpakket en het standaardenbeleid van her Nederlands Huisartsen Genootschap (NHG) onderschrijven (4.1). Tevens moet de praktijk aantoonbaar voldoende tijd besteden aan nascholing (3.9) en er moet voor onderwijsdoeleinden een additionele spreek- en onderzoekkamer aanwezig zijn (3.7).

\section{* Argumentatie om deel te nemen aan een academiseringsnetwerk (tabel 7.2)}

Gevraagd is naar de argumenten van de huisartsen en de vakgroep-medewerkers om deel te nemen aan de academisering van de huisartsgeneeskunde. De huisarts participeert om diverse redenen, variërend van wetenschappelijke interesse, affiniteit met onderwijs en onderzoek en verbetering van de eigen zorgverlening, tot idealisme en het feit "dlat het leuk is eens iets anders te doen". Ook de geldelijke vergoeding lijkt van belang, met dien verstande dat de huisartsen van mening zijn dat zij voor extra inspanningen als gevolg van de samenwerking met de universiteit op enigerlei wijze een vergoeding zouden moeten ontvangen. Binnen de vakgroep bestaat er behoefte aan academisering vanwege de noodzaak van een meer gestructureerde inzet van praktizerende huisartsen in onderwijs- en onderzoeksprojecten en bestaat er eveneens een meer ideëel motief, namelijk de principiële binding met het praktizerende veld van huisartsen.

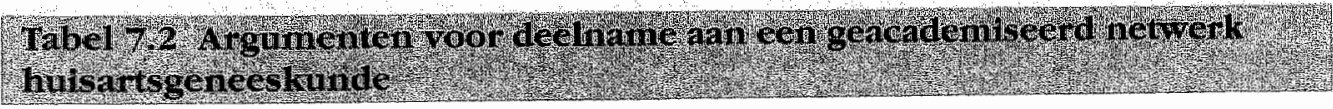

\begin{tabular}{|c|c|c|c|}
\hline ARGUMENTEN VOOR DE HUISARTS & $\begin{array}{l}\text { Huisartsen } \\
\text { Gentiddelde scotre } \\
n=34\end{array}$ & $\begin{array}{l}\text { Staf } \\
\text { Gemiddelde score } \\
n=18\end{array}$ & P-waarde \\
\hline Wetenschappelijke inleresse: & 4.1 & 3.9 & 0.20 \\
\hline Professionele carriere & 3.2 & 2.8 & 0.11 \\
\hline Mininteit & 3.9 & 3.7 & 0.30 \\
\hline Ideallisne & 3.9 & 3.6 & 0.20 \\
\hline Geldeliike wergoeding & 2.7 & 3.1 & 0.17 \\
\hline Nerbetering eigen zorgverlening & 4.0 & 39 & 0.55 \\
\hline Het is leuk lets anders te doen & 4.2 & 4.1 & 0.60 \\
\hline
\end{tabular}

\section{ARGUMENTEN VOOR DE UNIVERSTTEIT}

Meer gestructureerde inzet wan praktizerende

Guthiddelde scores op een wiffountsschad, wariërend wan 


\section{* Contract-technische relatie}

Zowel de grcep huisartsen (3.4) als de groep stafleden (2.9) staan neutraall tegenover het in Masastricht gehanteerde contractstelsel, bestaande uit een academiseringscontract voor onlsepaalde tijd, gekoppeld aan nader te definiëren inhoudelijke werkplannen.

Wat betreft de financiele relatie tussen de universiteit en de geacademiseerde huisantsen bestaat bij de huisartsen een lichte voorkeur voor betaling van de geleverde prestaties (tijd tegen geld) $(3.8 ; 3.5 ; \mathrm{p}=0.31$ ). De stafmedewerkers daarentegen zouden willen streven naar een ruil van menskracht tegen menskracht, waarbij de universiteit menskracht inzet in de gezondheidszorg en de gevestigde huisarts onderwijs- en onderzoekstaken teruglevert (cijd tegen tijd) $(3.1 ; 3.7 ; \mathrm{p}=0.09$ ). De verschillen tussen de groeperingen zijn niet significant.

\section{* Omvang en algemene doelstelling van academisering}

Het is opvallend dat integratie van onderwijs, onderzoek en patiëntenzorg als één van de hoofddoelstellingen van academisering genoemd wordt, terwijl tegelijkertijd door beide groepen wordt aangegeven dat eén netwerkpraktijk niet ingezet moet worden op alle bovengenoemde deelgebieden $(3.0 ; 2.9)$.

Het Maastrichtse netwerk, bestaande uit 30 huisartspraktijken met in totaal 83 huisartsen wordt niet te groot gevonden; onderlinge afstemming en communicatie komen volgens zowel de stafleden als de huisartsen niet in gevaar door de grootte van het netwerk.

\section{* Opleiding}

Er is geen verschil van mening over de noodzakelijke opleidingen voor geacademiseerde huisartsen. Alle in de enquête opgenomen opleidings-onderdelen worden belangriik gevonden (scores variëren van 3.7 tot 4.0). De geacademiseerde huisarts moet worden opgeleid op het gebied van management (met name time-management), automatisering (inclusief registratie), methodologie, statistiek en didactiek. Ook een introductie in de universiteil wordt van belang geacht.

\section{"Dualiteit tussen academische taken en patiëntenzorg}

In het verleden bleek dat de ontwikkeling van huisartsgeneeskundige geacademiseerde netwerken moeizaam tot stand kwam. In dit onderzoek werd dan ook aandacht besteed aan de mogelijke clualiteit tussen academische taken en patiëntenzorg. De huisartsen vinden dat zij in het algemeen te weinig tijd en gelegenheid hebben om actief deel te nemen aan het netwerk (4.0). Bovendien is een probleem dat de honoreringsstructuren onvoldoende op elkaar zijn afgestemd. Over deze twee knelpunten zijn de stafleden en de huisartsen het met elkaar eens. De mogelijke dualiteit ontstaat onder meer door gebrekkig tijdsmanagement; huisartsen en stafleden geven aan, dat bij keuzes onder tijdsdruk de patiëntenzorg altijd voorrang krijgt boven de academische taken $(3.5 ; 3.9 ; p=0.11)$.

\section{* Kwaliteitstoetsing academisering}

Beide partijen zijn van mening dat de doelstellingen en de te leveren inzet (kwalitatief en kwantitatief) van de geacademiseerde huisartsen voldoende duidelijk zijn. De vakgroep zou de netwerk-praktijken vaker (éénmaal per kwartaal) moeten visiteren ten einde alspraken en knelpunten te inventariseren en eventueel bijstellingen aan te brengen. De huisartsen onderschrijven dat kwaliteitscontrole van de geacademiseerde taken door middel van onderlinge toetsing goed mogelijk is, terwijl de stafleden het 
hier in mindere mate mee eens zijn $\left(3.8 ; 3.2 ; \mathrm{p}^{=0} 0.04\right)$. De huidige kwaliteitstoetsing in het Maastrichtse netwerk (door de vakgroep zelf) wordt noch voldoende, noch onvoldoende gevonden, terwijl de output van het academiseringsnetwerk nog verbeterd han worden (respectievelijk 2.3 en 2.7 over de gehele groep respondenten). Gebrekkige inzet of kwaliteit zou moeten leiden tot beëindiging van de samenwerking (4,2).

\section{*Invloed op uitoefening patiëntenzorg (tabel 7.3)}

De huisartsen vinden dat zij door hun deelname aan de academisering het huisartsen. vak beter en meer gestructureerd bijhouden en bovendien in aanaking komen met zaken, die ze bij de exclusieve uitoefening van het huisartsvak niet zouden leten. Door de academisering denkt de huisarts beter als huisarts te functioneren.

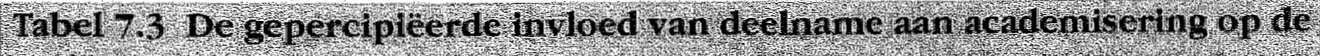
patienternorg

\section{INWLOED DEELNAME AAN NETWBRK OP DE PATTËNTENZORG}

Gemiddelde Score van

Thisartsen $\mathrm{n}=3$ a

Ik bijf beter bij door mijn betrokkenheid bij de academisering

kk leser door mijn betrokkenheld bij de universiteit zaken

die ith anders waarschijnlijk niet zou leren

Mijn attitude als huisarts verandert in positieve zin.

Ilk denk beter als huisarts te functioneren door mijn

Gemiddelde scores op een wifpuntsecbal, varierend wan

1 - in bet gebled niet mee eens

toi 5 - volledig mee eens

\section{* Consequenties voor de samenwerkingspartners van de huisarts}

Volgens de deelnemende huisartsen staan de doktersassistenten neutral tegenover de participatie an het academiseringsnetwerk, terwijl ze het anzienlijk drukker hebben gekregen door de diverse academische taken van de huisartsen (4.0). Ondanks deze grotere druk ervaren de doktersassistenten deelname aan de academisering niet als negatief. In de waarneemgroepen word door de andere huisartsen gematigd positief gereageerd op de deelname aan academisering (3.3). De omgang met de geacademiseerde huisarts in de waarneemgroep is niet verandend, en er is geen afgunstige bouding van de collega-huisartsen waarneembaar. Ook de andere eerstelijns werkers reageren positief. Toch hebben de geacademiseende huisartsen niet het idee anders of beter te functioneren in hun relatie met de doktersassistenten, collega-huisartsen en. andere eerstelijns werkers, als gevolg van hun deelname aan een academiseringsnetwerk (2.6).

\section{* Praktijkmanagement (tabel 7.4)}

Van de huisartsen geeft $76 \%$ aan dat de betrokkenheid bij de universiteit door de deelname an academisering tot organisatorische praktijkproblemen leidt van deze huis- 
artsen heeft $73 \%$, al dan niet in samenwerking met de universitaire vakgroep huisarts geneeskunde, oplossingen weten te bedenken voor deze problemen. De helft van de geacademiseerde huisartsen meldt dat de universiteit meer ondersteuning zou kunnen geven om deze (tijds)problemen op te lossen. Daarbij wordt met name gedacht aan een betere coördinatie van de universitaire taken, een betere afstemming van deze taken op de dagelijkse patièntenzorg, een meer persoonlike benadering van dle huis ants door de universitaire werkers en aan extra aandacht voor management-opleidingen. De tijd die de huisarts inzet overschrijdt regelmatig de contractueel vastgelegde tijdsl: mieten. Dit heeft te maken met het feit dat de geacademiseerde praktijken een extra aantrekkingskracht hebben, waardoor ook niet overeengekomen (uniwersitaire) projecten aan de huisartsen worden voorgelegd. De huisartsen hebben overigens geen moeite om niet-overeengekomen taken te weigeren. De huisartsen vinden zelf dat er niet te veel tijd besteed wordt aan overhead-taken, zoals overleg en dergelijke, terwit ook in de praktijken niet meer overleg noodzakelijk is als gevolg van deelname aan het academiseringsnetwerk. Slechts in geringe mate is er op praktijkniveau van aanpassingen in de organisatie sprake. Deze geringe herziening van de praktijkorganisatie wordt noch als voordelig, noch als nadelig ervaren, maar als noodzakelijk voor de uitvoering van de academische taken in combinatie met de patièntenzorgtaken.

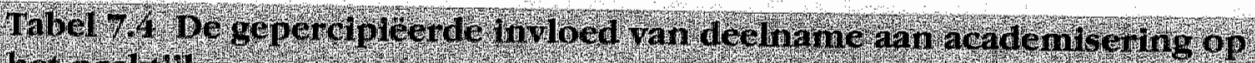

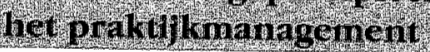

\section{INVLORD VAN DEELNAME AAN HET NETWERK OP HET PRAKTYJKMANAGEMENT}

Gemiddelde score $n=34$

3.9

3.4

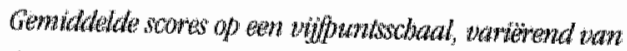

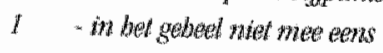

tor 5 - volwedig mos em 


\subsection{Beschouwing}

De beschreven evaluatie-studie werd uitgevoerd middels een anonieme schriftelijke enquête onder 29 vaste stafleden en 55 geacademiseerde huisartsen. Allen hebben op enigerlei wijze betrokkenheid bij het Huisartsgeneeskundig Academiseringsnetwerk Maastricht (HAM) van de Rijksuniversiteit Limburg.

Hoewiel het onderzoek zich beperkt heeft tot het HAM is een aantal conclusies van betekenis voor de andere regio's. Met name de infrastructurele aspecten kunnen naar onze mening ook in andere universitaire settings consequenties hebben in hun streven naar netwerkvorming op het gebied van de huisartsgeneeskunde.

Wij legden de volgende definitie van academisering voor:

'de gestructureerde/geinstitutionaliseerde samenwerking tussen universiteit en huisartspraktijken, waarbinnen onderling samenhangende en vooraf overeengekomen activiteiten plaatsvinden ten behoeve van de integratie van wetenschappelijk onderwijs, onderzoek en patiëntenzorg' $4,5,6,7$.

Deze definitie wordt weliswaar onderschreven, maar tevens complex en niet-gebrutkersvriendelijk gevonden.

De twee partijen (vakgroep en huisarts) moeten in de ogen van de respondenten een gelijkwaardige positie hebben in het netwerk.

De selectie van de te academiseren huisartsen geschiedt bij voorkeur door een delegatie van universitaire stafleden en praktiserende huisartsen, op basis van aantoonbare motivatie van de huisarts en de reeds opgedane ervaring met wetenschappelijke taken, opleiding en patiëntenzorg. De 'geacademiseerde' huisarts moet volgens de respondenten de bereidheid hebben tot onderlinge toetsing, geautomatiseerd werken en het standaardenbeleid van het Nederlands Huisartsen Genootschap (NHG) onderschrijven. Voorts moet de huisarts op een voldoende wijze de nascholingstijd invullen en dient de praktijk voor onderwijsdoeleinden te beschikken over een additionele spreek-annex onderzoekruimte.

Voor de huisarts zijn het met name ideële motieven, die deze bewegen deel te memen aan een netwerk. Affiniteit, idealisme en de behoefte om naast de patiëntenzorg lets anders te doen op het gebied van de huisartsgeneeskunde, zijn de meest onderschreven argumenten. De vakgroep heeft vooral een pragmatisch argument, namelijk de behoefte aan een meer gestructureerde inzet van praktiserende huisartsen in onderwijs- en onderzoeksprojecten. Idealiter zouden de geacademiseerde huisartsen werkzaam moeten zijn op alle wetenschappelijk deelgebieden van het academiseringsnetwerk; uit tijdsoverwegingen en ten behoeve van de te bereiken diepgang kan het echter nodig zijn dat huisartsen kiezen voor éen van de wetenschappelijke terreinen (of onderwijs of onderzoek of automatisering/registratie). Knelpunten in de samenwerking ontstaan onder meer door het gebrekkige tijdsmanagement, waarbij de prioriteit in het algemeen wordt gelegd bij de patiëntenzorg-taken. De output van het Maastrichtse academiseringsnerwerk zou volgens de betrokkenen nog kunnen toenemen. Het proces van kwaliteitstoetsing is voor verbetering vatbaar. Het regelmatig visiteren van de deelnemende huisartsen lijkt de beste waarborg om de kwaliteit en de inzet veilig te stellen. Nagedacht zou kunnen worden over het hanteren van onderlinge toetsing binnen het netwerk, ten einde de kwaliteitsaspecten te beoordelen. De deelnemende 
huisartsen denken door hun deelname aan academisering hun vak beter te kunnen uitoefenen. Waarschijnlijk komt dit doordat meer structureel aandacht wordt besteed aan het bijhouden wan het vak en doordat de huisarts in aanraking komt met een meer wetenschappelijke benadering, clie een kritische houding ten opzichte van het eigen handelen bevordert. De doktersassistenten van de geacademiseerde huisartspraktijken staan neutraal tegenover de participatie aan het academiseringsnetwerk, terwijl ze het drukker hebben gekregen door de diverse academische taken. Ondanks deze grotere druk wordt deelname aan de academisering niet als negatief ervaren. Dit is een belang: rijke constatering, aangezien de uitvoering van universitaire onderwijs- en onderzoeks: projecten mede gedragen wordt door de doktersassistenten.

Ook de overige eerstelijns werkers en de collega-huisartsen lijken positief te staan tegenover de deelname van de huisarts aan academiseringsnetwerken. De huisarts ervaart overigens geen verandering van de relatie met deze werkers. Deelname aan het academiseringsnetwerk heeft vooral consequenties voor het praktijkmanagement en kan aanleiding geven tor organisatorische praktijkproblemen.

Een meerderheid van de deelnemende huisartsen geeft aan deze problemen opgelost te hebben, maar tegelijkertijd wordt door meer dan de helft wan de respondenten aan de universiteit gevraagd meer ondersteuning te geven bij de oplossing van eventuele organisatorische problemen. Dit zou kunnen door een verbetering van de coördinatie van de diverse universitaire taken, door een betere afsternming hiervan met de patiëntenzorg, door een meer persoonlijke benadering van de huisartsen in het netwerk en door additionele aandacht voor management-opleidingen voor de deelnemende huisartsen.

De besteding van kostbare tijd aan overhead-taken (vergadertijd en dergelijke) blijkt mee te vallen. Wel hebben de geacademiseerde praktijken een grote aantrekkingskracht op andere, contractueel niet overeengekomen projecten. De huisartsen hebben overigens geen moeite met deze extra vragen om te gaan en wijzen ze af indien ze nietrelevant of niet interessant worden gevonden.

Al met al lijkt de conclusie gerechtvaardigd dat de ontwikkeling van het academisch netwerk van huisartspraktijken positief wordt gewaardeerd, zowel door de deelnemende huisartsen zelf als door de (universitaire) vakgroep.

De voordelen wegen op tegen de mogelijk nadelige effecten; organisatorische aanpassingen zowel binnen de praktijk als in de omgang van de universiteit met de praktijken worden gevraagd. Regelmatige visitatie, kwaliteitscontrole en goede wederzijdse communicatie kunnen als voorwaarden voor het welslagen van het netwerk worden
beschouwd. 


\subsection{Literatuur}

$\mathbb{1}$

Wan Londen. Acactemisering in de eerste hin als middel wot realisering van wolksgezondheidsdoelstellingra. In: Brouwer W, Romme MA], Faculteit en eerste lijn, Amsterdam; Bohn, Scheltema \& Hollkema, 1991 2.

Yas JC. Facultert en eerste lijn. Med Contart 1981; 35:547-9

3

Begeleidingscommissie Academisering Eerstelijns Geneeskinde. Onwikkelingsplan acadenisering huisattsgeneeskunde. BAEG 150,1991

4

Wrojectgroep Evaluatie Tijdelijke Stimuleringsregeling Universitaire Huisartspraktijken. Academiserirg in een newwerk, Verslag van een vragenlijstonderzoek. Amsterdam: Instiruut woor Hulsartsgeneeskunde, Uniketsteit van Amsterdam, 1990

5

Projectgroep Evaluatie Tijdelijke Stimuleringsregeling Universitare Huisatspraktiken. Acadenasering in zicht. Visies op de doelstellingen voor een netwerk, Amsterckam: Instinut voor Huisartsgeneeskunde, Unwersiteit Van Amsterdam, 1990

6

Projectgroep Evaluatie Tijdeljke Stmuleringstegeling Universitaire Huisartspraktiken. Academisering in de praktijk. Tussentijdse rapportage van de projectgrop evaluatie wan de tijdelijke Stimuleringsregeling Universitaine Huisartspraktijken. Amsterdam: Instituut voor Huisartsgeneeskunde, Universiteit van Amstendam, 1900

7

projectgroep Evaluatie Tijdelijke Stimuleringstegelng Universitaire Huisartspraktijken. Academisering in de husartspraktijk. Eindrappont van de Projectgroep Evahuatie van de Tijdelijke Stimuleringsregeling Universibaire Huisartspraktjhen, Amsterdam: Institumt woor Huisantsgeneeskunde, Universiteit wan Amasterian, 1900

8

Meijer J5, Schade E. Van gastdocent to UHP-asts: de onrwikleling van de academisering van de huistutsgeneeskunde. Huisarts wet $1992 ; 35: 2931$

)

Basisfilosofie van de Rijksuniwersiteit Limburg. Masstricht: Rijksuniversiteil Limburg, 1972

10

Beusmans GHMI et al. Medische Faculteit Mastricten earste lin: standpuntbepaling bestuwh PHV Masstricht. Med Contact 1981; 1.5: 437-41

II

Bronwer W. Academisering in de eerste lipm en noodzatk. Med Contact, 1982; 11: 321-2

12

Integnal plan voor universitare participatie in de reglonale gezondheidszorg. Massuicht Rijksuniversiteir Limburg, 1982 
Nona Academisering in de Eerstelin. Maastricht: Faculteit der Geneeskunde, Rijksuniversiteit Limburg 1982

14

Rappont wan de Commissie Academisering Eerstelingsgezondheidszorg cn Ambulante Geestelijke Gezondheidszong in Limburg. Maastricht: Rijkstiniversiteit Limburg, 1983

15

Diederiks JPM, Stewens FGJ. Ervaringen met het Acadenisch Ziekenhwis Masstricht: Een onderzoek naar de beelduoming wan een ziekenhuis. Maastricht 1991

16

Nieuwbouw academisch ziekenhuis Maastricht: beloften, belang en noodzaak. Academisch Ziekenthuis Mastricht Maastricht 1983

17

Nota Academisch Ziekenhuis inzake academisering. Mastricht, 1981.

18

Starmans R, Witte de L. Over het academisch ziekenhuis Maastricht gesproken. Amsterdam: SISWO, 1982 19

Projectorganisatie Acadentsche ziekenhuizen: Eindrapport deel B: Advies inzake de beleidsnotitie "Nadere regeling wan de verantwoordelijkheid woor academische ziekenhuizen". "s Gravenhage, 1987

20

Projectorganisatie Academische ziekenhuizen: Eindrapport deel A: Adwes inzake de uirvoering van het con. venant academische ziekenhuizen. 's Gravenhage, 1987 


\section{HOOFDSTUK 8}

\section{HET OORDEEL VAN HUISARTSEN \\ OVER DEELNAME AAN}

WETENSCHAPPELIJK ONDERZOEK

R.T. KOCKEN

A. PRENGER-DUCHATEAU

P.E.L.M. SMUETS-RINKTENS

J.A. KNOTTNERUS
Beheerder vakgroep hulsartsgeneeskuzde-1kijksuniversiteir Limburg, tevens coondinator Coorclinatiebureau Ferste Lin wan de Rijksuniversiteit Limburg

Huisarts, destijds huisarts-in-opleiding

Algemeen research-assistent wan de wakgroep huisartsgeneeskunde Hooglerat huisartsgeneeskunde

\section{Verantwoording.}

De belangrikste nesultaten van dit onderzoek zijn gepubliceerd in:

Kocken RD, Prenger-Duchateau A, Smeets-Rinkens PELM, Knotnerus JA.

Hew oordeel van huisartsen over deelname an wetensichappelijk onderzoek, Huisarts Wet 1992; 35(1):32-5.

Kocken RJ, Prenger-Duchateau A, Smeets-Rinkens PELM, Knotherus JA.

General Practitioners as participants in scientific research

- What do they think of it? - Newslleter WHO -2000 Healch for all- $1992 ; 18,24$.

Kocken RII, Knottnerus JA. General Practitioners as participants in scientific research;

Letwer to the editor Br J Gen Pract 1993:43,305.6

\section{Samenvatting}

Door middel van een enquête onder twee representatieve steekproeven van huisartsen die regelmatig of incidenteel deelnemen aan onderzoek vanuit de Rijksuniversiteit Limburg, en huisartsen die daaraan niet deelnemen, werd nagegaan welke criteria daarbij worden gehanteerd, welke problemen worden ondervonden, welke informatie door de huisarts vooraf en na afronding van het onderzoek wordt gewenst, en in hoeverre het dagelijks handelen van de huisarts door participatie aan wetenschappelijk onderzoek wordt beïnvloed. De respons was respectievelijk 68 procent en 51 procent. De bereidheid tot deelname aan onderzoek is in het algemeen groot. De belangstelling voor het gekozen onderwerp en de belasting voor patiënt en huisarts zijn de belangrijkste factoren bij de afweging om wel of niet deel te nemen. Een goede terugrapportage wordt op prijs gesteld en een niet onaanzienlijk deel van de huisartsen acht het van belang op enigerlei wijze genoemd te worden als deelnemer. Ongeveer de helft van de responderende huisartsen vindt het redelijk een vergoeding voor extra bestede tijd te ontvangen. 


\subsection{Inleiding}

In kringen van wetenschap en beleid wordt in toenemende mate aandacht besteed aan structuren voor samenwerking tussen universiteiten en andere instellingen of privê-personen. Ook in de gezondheidszorg, met name in de eerstelijns gezondheidszorg, ontstaat hiervoor steeds meer belangstelling. Het vooral bedrijfskundig georiënteerde rapport 'Samen werkt het beter' gaf een eerste modelbeschrijving van de mogelijkheden tot samenwerking tussen universiteiten en huisartsen ${ }^{1}$.

Aan de Rijksuniversiteit Limburg is een onderzoek verricht onder 350 huisartsen met als vraagstelling:

- Wat zijn de criteria voor huisartsen om aan wetenschappelijk onderzoek mee te werken?

- Welke problemen ondervinden huisartsen in hun samenwerking met universiteiten op het gebied van wetenschappelijk onderzoek en welke informatie wordt door de huisarts vooraf en na afronding van het onderzoeksproject gewenst?

- Wordt het dagelijks handelen van de huisarts door participatie aan wetenschappelijk onderzoek beïnvloed?

\subsection{Methode}

Voor het onderzoek werd de facultaire regio, bestaande uit 564 huisartsen in Limburg en het Zuidoostelijk deel van Noord-Brabant, onderscheiden in twee deelpopulaties: 331 huisartsen die regelmatig of incidenteel deelnemen aan wetenschappelijk onderzoek en/of onderwijs vanuit de universiteit ('participanten'), en 215 huisartsen die daar tot 1 januari 1989 niet aan hadden meegedaan ('non-participanten'). Uit deze twee deelpopulaties werden at random respectievelijk 150 en 200 huisartsen geselecteerd, waarbij de verwachting was dat de respons in de non-participantengroep veel lager zou zijn dan die in de participantengroep.

De geselecteerde huisartsen ontvingen in mei 1989 een vragenlijst, bestaande uit vifftien gesloten vragen. De vragenlijst werd ontwikkeld in samenwerking met de vakgroep Medische Sociologie van de Rijksuniversiteit Limburg.

Bij de meeste vragen was er slechts eén antwoordmogelijkheid; bij drie vragen werd gevragd een prioriteit van $1 \mathrm{t} / \mathrm{m}$ aan te geven. Deze prioriteiten zijn in de analyse herleid tot een 5 -puntscore, waarbij de hoogst scorende variabele 4 punten kreeg en de niet aangekruiste 0. In september 1989 werd de non-respondenten een nieuwe vragenlijst met een reminder toegezonden.

De statistische analyse van de verschillen tussen beide groepen werd uitgevoerd met de chi-kwadraattoets voor onafhankelijke steekproeven bij categorische variabelen, en met de t-toets bij numerieke variabelen. Er werd tweezijdig getoetst, met een signifi-
cantiedrempel van 0,05 .

\subsection{Resultaten}

\section{Respons}

Van de 350 benaderde huisartsen respondeerden er uiteindelijk 211 ( 60 procent). De respons in de participantengroep bedroeg 68 procent, die in de non-participantengroep 51 procent. Daarnaast was er nog 4 procent aan 'respons' met niet-correct inge- 
vulde formulieren. De gemiddelde leeftijd bedroeg 43 jaar, zonder duidelijke verschillen tussen de twee onderzoeksgroepen. De mar/vrouw-verdeling was 91 versus 9 procent. Van de deelnemers was 33 procent werkzaam in een stadspraktijk, 28 procent in een plattelandspraktijk en 40 procent in een mengworm.

Wan de participantengroep deed 77 procent - incidenteel of regelmatig - mee aan onderzoek door en begeleid vanuit de farmaceutische industrie. In de non-participantengroep was dat 74 procent.

\section{Criteria}

De criteria om deel te nemen aan wetenschappelijk onderzoek konden worden aangegeven met een score van 1-4. Uit de gemiddelde scores blijkt dat de deelnemers met name rekening houden met de eigen interesse met betrekking tot de onderzoekswaagstelling, en met de verwachte belasting voor huisarts en patienten (figmur 8.1 ). De verschillen tussen de twee onderzoeksgroepen waren in geen van de gevallen significant.

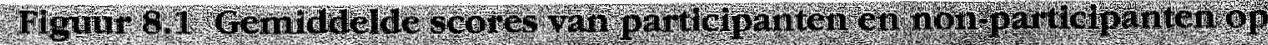

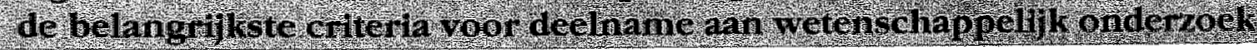

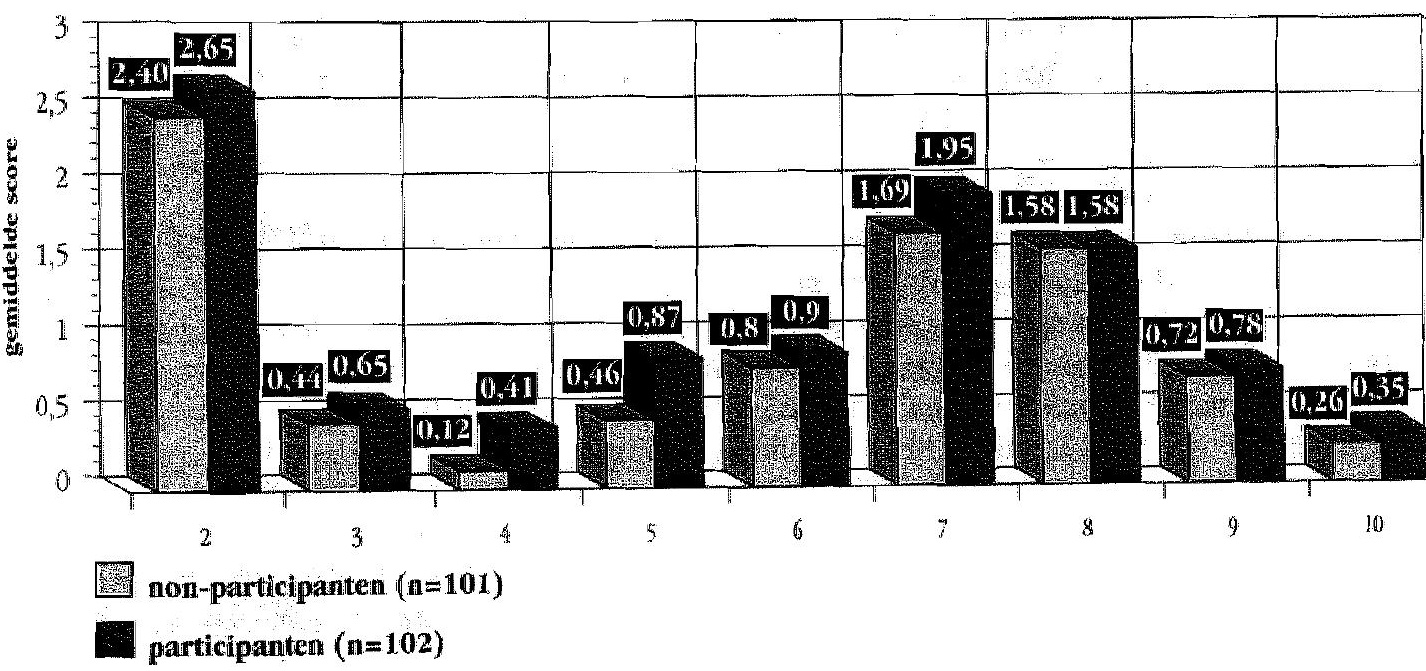

2 interesse onderwerp; 3 vergoeting; 4 vertrouwen RL; 5 vertrouwen onderzoetcer; 6 goede projectpresentalie; 7 acceptabele bellasting huisarts; 8 acceptabele belasting patient; 9 acceptabele duum onderzok; 10 anderzins

De vraagstelling, waarom huisartsen in voorkomende gevallen ntet aan onderzoek deelnemen, gaf overeenkomstige uitkomsten, zij het dat met name de verwachte belasting woor patient en huisarts nu een grotere rol speelde, terwijl een gebrek aan interesse in het onderzoek veel lager scoorde (figutur 8.2). Verder vertoonde de score bij niet-deelname duidelijk minder differentiatie tussen de diverse variabelen. Ook hier waren er geen significante verschillen tussen beide onderzoekspopulaties. 


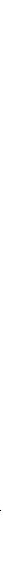

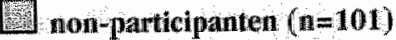

participanten $(\mathbf{n}=102)$

1 geen intercsese wetenschappeli $\mathrm{k}$ onderzoek; 2 geen interesse in onderwerp; 3 onvoldoende vergoeding; 4 geen vertroutwen Rils; 5 geen vertrowwen onderzoker; 6 slechte presen hatie; 7 onacceptabele belasting huisarts; 8 onacceptabele betasting patient; 9 onacceptabete duur onderzoek; 10 anderzins

\section{Ervaren problemen}

Ook uit de antwoorden op de vragen over optimale informatie-voorziening vooraf en de meest voorkomende problemen achteraf (in geval van deelname) blijkt dat de genoemde drie aspecten -interesse voor het onderwerp, belasting voor de patiënt en belasting voor de huisarts - belangrijk worden gevonden De deelnemers ervaren het als een probleem dat de vooraf gegeven informatie over het onderzoek vaak onvoldoende is (score 1.34) en dat het onderzoek weinig aansluit bij de dagelijkse praktijk (1.37). De informatievoorziening tijdens de uitvoering van het onderzoek werd daarentegen niet als onjuist of onvoldoende ervaren (respectievelijk 0.5 en 0.05 ). Opvallend gunstig is verder dat de items 'Afspraken worden door de onderzoeker niet nagekomen' $(0.25)$, 'De onderzoeker motiveert niet of te weinig' (0.64) en 'De uitvoering van het onderzoek heeft onacceptabele consecjuenties voor de doktersassistente' (0.52) laag scoorden.

\section{Gewenste informatie achteraf}

Van de ondervragden antwoordde 60 procent grote waarde te hechten aan toezending van het eindresultaat: artikel of proefschrift, en in ieder geval een samenvatting; 37 procent stelt prijs op een presentatie van de resultaten in de vorm van een voorlichtingsbijeenkomst. Slechts 1 procent gaf te kennen geen nadere informatie te wensen. Tweederde ( 63 procent) vond het niet belangrijk om met naam genoemd te worden, 27 procent vond dat wel belangrijk. Van deze 27 procent vond 18 procent dat de huisarts als mede-auteur vermeld zou moeten worden, terwijl 36 procent antwoordt vermelding in her dankwoord acceptabel te vinden. De overige 46 procent zou de wijze van vermelding afhankelijk willen stellen van de geleverde bijdrage. 


\section{Vergoeding}

Van de onderzoekspopulatie vindt 89 procent dat hun bijdrage op enigerlei wijze redelijk vergoed moet worden; slechts 5 procent vindt dit onnodig. Er worden hier geen significante verschillen tussen de twee onderzoekspopulaties aangetroffen.

Volgens 46 procent van de huisartsen is een vergoeding tussen de NLG 50 , en NLG $100,=$ per uur extra tijdsbelasting redelijk; 24 procent dacht aan een hogere vergoeding en 25 procent dacht aan een lagere.

Bij de non-participanten wordt iets vaker voorkeur uitgesproken voor een hogere vergoeding dan bij de participanten-groep (27 procent versus 22 procent). De vergoeding zou idealiter uitbetaald moeten worden in de vorm van contant geld ( 58 procent) en/of materiaal voor de praktijk (47 procent) (tabel 8.3 ).

\section{Tabel 8.3 Wat acht in een redelike unvergoeding bif deel hame aan weten} schappelijk onderzoek

\section{Percentages}

\begin{tabular}{ccc}
\hline & $\begin{array}{c}\text { Participanten } \\
\mathbf{n = 1 0 2}\end{array}$ & $\begin{array}{c}\text { Non-participanten } \\
\mathbf{n}=101\end{array}$ \\
\hline$<25$ gudden & 2 & 4 \\
$25-50$ gulden & 24 & 17 \\
$50-100$ gulden & 44 & 36 \\
$>100$ gulden & 24 & 20 \\
(Geen significante trerscbillow) & & \\
\hline
\end{tabular}

\section{Beinvloeding dagelijks handelen van de huisarts}

Tenslotte werd aan de huisartsen gevraagd of en in welke mate hun dagelijks handelen beinvloed wordt door participatie aan wetenschappelijk onderzoek. 79 Ptocent van de huisatsen zegt dat het praktisch handelen wel degelijk in meerdere of mindere mate wordt beinvloed (tabel 8.4 ).

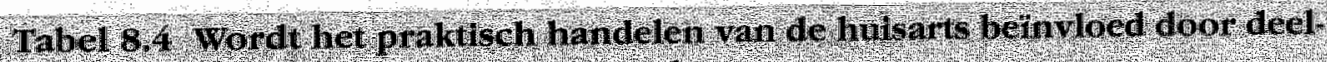

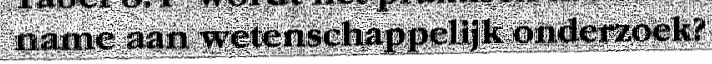

Percentages

\begin{tabular}{rcc}
\hline & $\begin{array}{c}\text { Participanten } \\
\mathbf{n = 1 0 2}\end{array}$ & $\begin{array}{c}\text { Non-participanten } \\
\mathbf{n}=\mathbf{1 0 1}\end{array}$ \\
\hline niet & 1 & 4 \\
inauweligks & 13 & 6 \\
in mindere mate & 45 & 42 \\
in sterke matte & 35 & 38 \\
(Geen significante verscbillen) & & \\
\hline
\end{tabular}




\subsection{Beschouwing}

Bij geen van de onderzochte items was een bepaald antwoord als sociaal wenselijk te beschouwen, en wif denken dan ook dat hierdoor geen vertekening is opgetreden; het ging immers om het aangeven van een bepaalde volgorde van items die alle wan belang konden zijn. Bovendien was het duidelijk dat de gegevensverwerking anoniem was, en bestond de gelegenheid additionele opmerkingen te maken. Van deze mogelijkheid is overigens weinig gebruik gemaakt, en de weinige opmerkingen lewerden geen relevante aanvullende variabelen op.

Uit de internationale literatuur zijn twee vergelijkbare onderzoeken bekend ${ }^{2,3}$. In een Canadees onderzoek $\mathrm{k}^{3}$ onder 120 huisartsen bleken de vertrouwelijke behandeling van patientgegevens en resultaten van onderzoek het belangrijkste onderdeel van het afwegingsproces. Tevens zag de Canadese huisarts participatie aan wetenschappelijk onderzoek als een mogelijkheid om de eigen sterke en zwakke punten op bepaalde gebieden (en soms in vergelijking tot collega-huisartsen) beter te kunnen ontdlekken. Aangezien wij in het verleden nauwelijks op problemen zijn gestuit op het gebied wan de privacy-bescherming, is hierover in onze studie geen expliciete vraag gesteld. Bovendien is dit aspect door geen van de respondenten genoemd.

Een Australische studie ${ }^{2}$ onder 3350 huisartsen vertoont veel parallellen met ons onderzoek. Tijdsbelasting voor patiënt en huisarts scoorde hier hoog, terwijl ook de hoogte van de vergoeding belangrijk werd gevonden. Verder werd in Australië de te verwachten steun van de projectleider als een belangrijke variabele genoemd.

Uit ons onderzoek blijkt dat de bereidheid van huisartsen om deel te nemen aan wetenschappelijk in het algemeen groot is. Mogelijk wordt hierbij de weg naar de farmaceutische industrie sneller gevonden dan die naar wetenschappeliike instellingen. De vaak kortere looptijd van industrieel onderzoek en de hogere vergoedingen door de industrie spelen hierbij wellicht een belangrijke rol.

veel onderzoekers zijn van mening dat het eindresultaat van het onderzoek in ieder geval aan de deelnemende huisartsen ter hand zou moeten worden gesteld; een niet onaanzienlijk deel stelt daarnaast prijs op expliciete vermelding van de namen van de deelnemende huisartsen in het eindresultaat. De fase van 'liefdewerk oud papier' en vrijblijvendheid is voorbij; de opvatting wint terrein dat bijdragen van huisartsen aan wetenschappelijk onderzoek vergoed dienen te worden.

\section{Literatuur}

1

Bhtnken Al, Oudkerk RH, Samen werkt het beter. Een ondezzoek naar de samenwerking tussen universibejten en huisartsen. Groningen, 1988

2

Borgiel AEM, Dunn EV, Lutronot CT, et al. Recruiting family physicians as participants in research. Fam Pract $1989,6: 168-72$

3

Silagy CA Caroon NE. Factors inflecting the lewel of interest and activity in primary cane research among genenal protitioners. Fam Puact $1989 ; 6: 173-6$ 


\title{
DE PLANNING EN COÖRDINATIE VAN ONDER-
}

\section{WIJS EN ONDERZOEK IN HUISARTSPRAKTIJKEN;}

\author{
volgt de huisarts bij participatie aan universitaire projecten de \\ opgegeven voorkeursgebieden?
}

R.I. J Kocken

J.A.Knottnerus

H.F.J.M. Crebolder

P.E.L.M. Smeets-Rinkens

J. Blommarert

\author{
Beheerder vakgroep huisantsgeneeskunde \\ Hoofd Coondinatiebureau Eerste Lijn \\ Hoogleratr huisartsgeneeslounde \\ Hoogleraar huisartsgeneeskunde \\ Onderzoksassistente wakgroep huikarsgeneeskunde \\ Universitair docent vakgroep Berichtgeving \\ Faculteir der Economische Wetenschappent
}

\section{Verantwoording}

Ter publikatie angeboden.

\subsection{Inleiding}

In het hier beschreven onderzoek gaat het om de vraag in hoeverre huisartsen duidelijke voorkeuren hebben voor bepaalde onderwerpen in de samenwerking met de universiteit, en of zij deze ook weten te realiseren. Deze vragen zijn van belang in verband met de planning van een dergelijke samenwerking. Daarbij speelt een centrale rol in hoeverre een relatief ongestuurd vraag-aanbod mechanisme leidt tot bevredigende resultaten woor de samenwerkingspartners. Verondersteld werd dat de huisarts als generalist in de gezondheidszorg, ook bij participatie aan onderwijs en onderzoek breed geinteresseerd zou zijn. De keuze voor uiteindelijke participatie vindt niet alleen plaats op basis van de geformuleerde inhoudelijke of thematische voorkeur. Bif elke universitaire vraag wordt afgewogen of het totale pakket (inhoud, organisatie, belasting voor huisarts/patiènt en financièn) interessant genoeg is om deelname toe te zeggen. Aanleiding van het onderzoek was het besluit van het bestuur van de Faculteit der Geneeskunde van de Rijksuniversiteit Limburg goedkeuring te verlenen aan het plan te komen tot een betere coördinatie van de samenwerking met het huisartsgeneeskundige veld. Met de oprichting van een zogenaamd Coördinatiebureau Eerste Lijn (CEL) werd een enquête (de voorneting) gehouden onder de huisartsen van de toenmalige universitaire regio. De regio betrof het geografische gebied, beginnend bij Maastricht en eindigend bij de denkbeeldige lijn Venlo-Helmond-Eindhoven. Het ingestelde Coördinatiebureau Eerste Lijn starte 
aldus haar activiteiten met en inventarisatie van de woorkeuren van de huisartsen im het werkgebied. Doelstelling wan deze inventarisatie was bij toekomstig onderwigs en onderzoek rekening te houden met de woorkeuren van de huisartsen op het gebiefl van onderwijs en onderzoek. Het bleek echter al snel dat het onmogelijk was structureel rekening te houden met de opgegeven vookkeuren. Doorgaans werd gekozen voor een benadering van het totale veld, ten einde de keuze voor deelname aan een specifiek project telkens geheel aande huisartsen over te laten.

Het is dan ook mogelik wa te gaan in hoeverre huisartsen, zonder directe sturing dan wel specifieke benaderingsstrategie vanuit de universiteit, de eigen voorkeur, opgegeven in 1988, in de jaren $1989 \mathrm{t} / \mathrm{m} 1992$ daadwerkelijk volgden.

Vraagstelling van het onderzoek is welke de voospellende betekenis is van de door de husartsen opgegeven voorkeuren in het kader van de participatie anan universitair onderwijs en wetenschappelijk onderzoek.

Inzicht op dit terrein is van belang ondat aldus cluidelijk wordt of huisartsen in de praktijk daadwerkelijk rekening houden met tevoren opgegeven voorkeuren. Als dat laatste het geval is, zou bij nieuwe projecten een meer gerichte en efficiënte benadering in aanmerking komen.

\subsection{Methode en populatiebeschrijving}

Het onderzoek werd verticht door vergelijking van de gegevens van de in 1988 gehouden voometing, met de concrete participatie-gegevens van de regionale huisartsen, aan drie uitgevoerde onderwijs- en vifftien onderzoeksprojecten in de periode tot 1993.

De voormeting vond plaats middels een gestructureerde, schriftelijke enquête onder 350 huisartsen in de unversitaire regio van de Rijksuniversiteit Limburg. Bij de bekendmaking van de start van het Coördinatiebuneau Eerste Lijn vond een énmalige benadering van deze huisartsen plaats. In de enquête werd naast de persoonskenmerken van de huisarts, gevraagd naar een aantal praktijkenmerken (onganisatie- en urbanisatiegraad, spreekutr-vorm) en naar structurele samenwerkingsvormen binnen de eerste lijn en met khische specialismen. Belangrijkste onderdeel van de voometing was de specifieke belangstelling van de huisats op het gebied van onderwijs en onderzoek.

Nadat de algemene vraag naar de belangstelling voor onderwijs- en/of onderzoekparticipatic gesteld was, werd gevraagd een nadere differentiatie van deze belangstelling aan te geven. Binnen de onderwijscomponent kon de huisarts aangeven of hij/zij
geinteresseend was in de onderdelen:

1. Orièrntatie Eerste Lijn (kennismakingsstage in studiejaar 1)

2. Praktisch Medisch Onderwijs in de huisartspraktijk (coschap in studiejaar $5 / 6$ )

3. Huisartsopleiding (de inmiddels 2-jarige specialisatie tot huisarts) 
Voor het onderzoeksgedeelte werd een onderscheid gemaakt in: 1

Medisch onderzoek in de praktijk:

a. waarde diagnostische gegevens

b. effect van therapieën

c. prognose van aandoeningen

2

Functioneren van de huisarts

a. kwaliteit van handelen.

b. huisarts-patiènt relatie

c. intercollegiale toetsing

3

Psycho-sociale klachten in de huisartspraktijk

a. beloop

b. beïnvloedingsaspecten

4

Onderzoek van onderwijs in de huisartspraktijk

5

Begeleiding chronisch zieken; thuiszorg

De gegevens van deze voormeting werden gerelateerd aan de informatie over concrete participatie van de huisartsen aan onderwijs- en onderzoeksprojecten, geinitieerd wanuit de vakgroep huisartsgeneeskunde (de nameting; peiling 1993). In maart 1993 werd daarom aan alle onderzoekers/coördinatoren van drie onderwijs- en vijftien onderzoeksprojecten gevraagd welke huisartsen daadwerkelijk aan de projecten hadden deelgenomen in de periode $1989 \mathrm{t} / \mathrm{m} 1992$.

Voor het onderwijsdeel was de relatie tussen voor- en nameting een directe, aangezien beide metingen relevante informatie bevatten over de onderdelen Orièntatie Eerste Lijn, Praktisch Medisch Onderwijs in de Huisartspraktijk en de Huisartsopleiding.

voor het onderzoeksdeel moest echter een vertaalslag plaatsvinden; een panel van 2 hoogleraren huisartsgeneeskunde, op de hoogte van de uitgevoerde onderzoeksprojecten, gaf aan welke concrete projecten behoorden tot bovengenoemcle viff onderzoekscategoriën van de voormeting. Dit leidde tot de indeling zoals aangegeven in tabel 9.1.

De classificatie van de projecten in de onderzoekscategoriën door de twee panelleden geschiedde onafhankelijk van elkaar; er waren geen verschillen van mening tussen de twee panelleden. Wel. gaven de panelleden bij sommige projecten aan dat er ook een tweede ordeningsmogelijkheid bestond. Bij de analyse is echter alleen rekening gehouden met de overeenkomende, eerste voorkeuren van de panelleden.

De data-analyse vond plaats door middel van frequentieverdelingen en kruistabellen. De relatie tussen woometing en nameting werd uitgedrukt in relatieve risico's (met bijbehorende p-waarden volgens Pearson's chikwadraat toets en indien nodig volgens de Fisher exact test en $95 \%$ betrouwbaarheidsintervallen), waarbij het daadwerkelijk participatiepercentage onder huisartsen die een bepaalde voorkeur vooraf hadden werd gedeeld door het overeenkomstige percentage onder huisartsen zonder die voorkeur. 


\section{Categorie in de VOORMETING}

Medlisch onderzoek in de huisartspraktij]k

\section{Projecten in de NAMETING}

Optimale beschriping en implementatie van een cholesterolstandaard in de huisartspraktijj: $k^{2,3}$

Prostaathyperplasie in de huisarisgraktij $k^{4,5}$

Hartritme-stoomissen

Diagnostiek van hpertensie in de huisartspraktij ${ }^{6}$

Perifeer Arterieel hatlijden in de huisartspraktijk; natuurlijk beloop en interventie $7,8,9$

Primaine preventie van AtheroTrombiolische processen bij non-Yadvulair Atrium Fibrileren in de huisartspraktijk (PATAF) 10

Het effect van influenza-vaccinatie in de huisartspraktijk ${ }^{\text {11,2 }}$

Applicalbility of 24 hour

bloodpressure registration in general practice (24 uurs

bloeddrukmeting in de huisartspraktijk) ${ }^{13}$

Niet-acute buikklachten in de huisartspraktijk ${ }^{14,15}$

Gezamenlijk consult huisants-specialist in de huisartspraktijk voor problemen met betrekking tot het bewegingsappdratit ${ }^{16}$

Patiëntenwoorlichting in de huisartsjoraktijk ${ }^{17}$

Technische wardigheden 18,19

Somatisatie in het dagelijks leven: een huisartsgeneeskundig cohortonderzoek 20,21

Kennistoet ${ }^{22,23}$

Thuiszorgorojec ${ }^{24,25}$

\subsection{Resultaten}

\section{De voormeting}

De voormeting vond plaats in 1988 . In total werden 350 huisartsen aangeschreven, waarvan er $153(44 \%)$ respondeerden. De verdeling van de voorkeuren wordt zichtbaar gemaakt in tabel 9.2 .

Wan de respondenten blijkt $24 \%$ geen belangstelling vooraf te hebben in participatie aan onderwijs en/of onderzock. Van de wel geinteresseerde 116 huisartsen blijkt een meerderheid van 68 huisartsen $(58 \%)$ zowel onderwijs- als onderzoeksparticipatie te willen overwegen.

Ten anzien van onderwijs was er brede belangstelling voor alle drie de onderdelen, waarbij de huisartsopleiding het hoogst scoont. 
De huisartsen gaven verder aan met name geinteresseerd te zijn in onderzoeksparticiparie aan projecten op het gebied van "Medisch Onderzoek in de huisartspraktijk" en "Functioneren van de huisarts".

\section{De nameting}

In maart 1993 werd aan alle onderzoekers wan 3 onderwijs en 15 onderzoeksprojecten gevraagd welke huisartsen daadwerkelijk aan het projecten hadden deelgenomen in de periode $1989 \mathrm{t} / \mathrm{m}$ 1992. Het aantal participerende huisartsen varieent van project tot project. Voor het onderwijsproject Praktisch Medisch Onderwijs in de Huisartspraktijk (PMOH) zijn jaarlijks 80 huisartsen nodig voor de opleiding van 120 140 studenten. Voor de huisartsopleiding worden permanent 66 aanstaande huisartsen opgeleid, hetgeen betekent dat er eveneens 66 huisartsen in de universitaire regio bereid moeten zijn deze opleiding voor de duur van momenteel 2 jaar te verzorgen.

Bij de onderzoeksprojecten varieert het aanal deelnemende huisartsen sterk; van 12 huisartsen uit de regio Maastricht (gezamenlik consult) via 125 huisartsen in de gehele regio Limburg/Brabant (Atrium Fibrileren=PATAF-studie) tot bijna 200 huisartsen met een landelijke spreiding (kennistoets en patiëntenvoorlichting).

\section{Tabel 9.2 De voormeting, geformuleerde voorkeureh van huis sartsen ten ahmilen van participatie aan onder wils en onderzels}

$\begin{array}{lcr}\text { Belangstelling voor onderwijs ew/of onderzoek } & \text { Voormeting 1988 } & \mathbf{n = 1 5 3} \\ & \mathbf{n} & \% \\ \text { belangstelling exclusief woor onderwijs } & 20 & 13 \\ \text { belangstelling exclustef voor onderzoek } & 28 & 18 \\ \text { belangstelling yoor onderwijs en onderzoek } & 68 & 44 \\ \text { geen belangstelling } & 37 & 24 \\ & 153 & 100\end{array}$

Specificatie voorkeuren onderwijs

Oriênatatie Eerste Lin

Praktisch Metisch Onderwijs in de Huisartspraktijk

Huisartsopleiding

alle onderwissonderdelen

\section{$n=88$}

n $\%$

$35 \quad 40$

4450

$53 \quad 60$

3

\section{Specificatie voorkeuren Onderzoek}

Medisch onderzoek in de huisartspraktijk

Functioneren van de huisarts

Psycho-sociale ktachten in de HA-praktijk

Onderzoek van Onderwijs

Beggeleiding chronisch zieken

alle onderzoekscategorieën

\section{$n=96$}

$59 \quad 63$

$59 \quad 63$

$22 \quad 23$

$16 \quad 17$

$29 \quad 31$

4 


\section{Verhouding voor-en nameting}

Van de 153 huisartsen in de voometing hebben er $109(71 \%)$ in de periode 1989-1993 deelgenomen aan minimaal één project.

Slechts 44 huisartsen uit de voormeting hebben geen samenwerking gehad met de vakgroep huisartsgeneeskunde van de Rijksuniversiteit Limburg. Opvallend is dat wan de 44 niet-participanten 13 huisartsen (30\%) in 1988 aangaven belangstelling te hebben voor deelname aan zowel onderwijs als onderzoek; daarenboven gaven nog eens 5 en 4 huisartsen aan exclusieve belangstelling te hebben woor respectievelijk onderwijs of onderzoek. Van de 44 niet-participanten gaven dus $22(50 \%)$ huisartsen wël een voorkeur voor onderwijs en/of onderzoek.

De relatie tussen voor- en nameting wat betreft het al dan niet deelnemen aan tenminste één project wordt weergegeven in tabel 9.3 .

Van de 109 huisarts-participanten gaf slechts $14 \%$ bij de voormeting aan in het geheel niet geinteresseerd te zijn; de overige 94 huisartsen hadden belangstelling voor onderwijs en/of onderzoek.

De participatiegraad van huisartsen, die vooraf al dan niet interesse hadden in deelname, was respectievelijk $81 \%(94 / 1.16)$ en $41 \%(15 / 37)$, hetgeen overeenkomt met een relatief risico (RR) van 2.0 (95\% betrouwbaarheidsinterval $1.3-3.0 ; p<0.001$ )

\section{Tabe1 9. 3 Onderwis en/of onderzoel algemeen}

\section{Onderwijs en/of onderzoek algemeen}

Voormeting 1988 *

Totaal

Relatief risico $=$

$95 \%$ confidence interwal $=1.3 \cdot 30$

Peator $\quad p=0.00$

$\begin{array}{lrr}\text { Nameting } 1993 & \text { Totaa } \\ + & - & \\ 94 & 22 & 116 \\ 15 & 22 & 37 \\ 109 & 44 & 153\end{array}$

\section{Totaal}

116

37
153

Geconstateerd kan worden dat er cen duidelijk verband bestaat tussen de door de huisartsen opgegeven voorkeuren en de daadwerkelijk participatie aan universitaire projecten. Toch besluit $41 \%$ van de huisartsen zonder belangstelling vooraf, uiteindelijk toch om aan universitair onderwijs en/of onderzoek te gaan deelnemen.

Hoewel procentueel meer huisartsen uit de onderzoekspopulatie deelnemen aan onderzoek dan atan onderwijs is het verband tussen voor-en nameting voor het onderwijs sterker dan voor het onderzoek (RR is respectievelijk 2.0 en 1.8).

Het verband tussen de in 1988 opgegeven voorkeuren en de daadwerkelijke participatie aan universitaire projecten is het grootst bij de reeds langer bekende onderwijsprojecten Huisartsopleiding ( $R R=8.7 ; p<0.001)$ en het coschap Praktisch Medisch Onderwijs in de huisartspraktijk (RR=3.7; $\mathrm{p}<0.001)$.

Bij de onderzoeksprojecten is het verband het grootst bij de projecten in de categorie 'Medisch onderzoek in de praktijk' $(R R=1.7 ; \mathrm{p}<0.001)$. Bij twee onderzoeksprojecten kan het verband niet berekend worden, enerzijds doordat géen van de huisartsen uit 
de ondenzoekspopulatie uiteindelijk aan het project deelnam (project technische vaar digheden'), anderzijds doordat de gegevens van de deelnemende huisartsen bij het afsiuiten van de analysefase nog niet bekend waren (project "Kennistoets")

De tabellen 9.4 tot en met 9.10 geven de diverse verbanden tussen voor-en nameting wan de diverse onderwijs- en onderzoekprojecten of categorieèn. Van drie onderzoekscategorieën wordt het verband niet gegeven aangezien het panel slechts én project in de betreffende categorie onderbracht.

\subsection{Beschouwing}

De resultaten geven aan, dat er een verband bestaat tussen door huisartsen uitgesproken voorkeuren en de uiteindelijke participatie a an universitaire projecten. Zelfs zonder directe sturing in de vorm van een gestratificeerde benaderingsstrategie is het verband tussen de voor-en de nameting in het algemeen duidelijk. Dat het verband bij de onderwijsprojecten groter is dan bij de onderzoeksprojecten was te verwachten. Bij het uitspreken van de voorkeuren waren de onderwijsprojecten Orientatie Eerste Lijn (OEL), Praktisch Medisch Onderwijs in de Huisartspraktijk (PMOH) en de Huisartsopleiding (HAO) reeds bij de huisartsen bekend. Sommige huisartsen waren zells reeds verbintenissen met de vakgroep aangegaan voor een samenwerking op eén van deze terreinen. De huisarts wist dan ook in 1988 waar ja of nee tegen werd gezegd. Ten aanzien van onderzoek was de situatie nadrukkelijk anders. De huisartsen spraken een eventuele voorkeur uit voor een vijftal onderzoekscategorieen, zonder op dat moment te weten welke projecten in het kader van die categorieën in de verdere toekomst zouden worden ontwikkeld en uitgevoerd.

Het verband is echter zodanig dat aangenomen mag worden dat huisartsen vooral op basis van inhoudelijke voorkeuren aan specifieke projecten gaan deelnemen. Het wordt aanbevolen de toekomstige benaderingsstrategie meer af te stemmen op de door de huisartsen uitgesproken voorkeuren. Het gerichter benaderen en werven van huisartsen voor universitaire projecten kan voordelen hebben voor zowel de universiteit als de huisarts. Voor de universiteit werkt een dergelijke benadering waarschijnlijk kosten-effectiever, aangezien momenteel (zelfs voor kleinere projecten) de gehele regio van circa 600 huisartsen regelmatig benaderd wordt. Voor de huisarts is het een woordeel dat er geen benaderingspoging wordt ondernomen indien wooral is dangegeven dat voor het specifieke onderwerp geen belangstelling bestaat. Het aantal onnodige benaderingen van de praktijk neemt daardoor aanzienlijk af.

Aanbevolen wordt om de inventarisatie nogmaals te herhalen na hernieuwde vaststelling van de categorieën waarvoor belangstelling kan worden uitgesproken. Het uirvoeren van cleze inventarisatie in nauwe samenwerking met de DHV (Districts Huisartsen Vereniging) zal de respons waarschijnlijk kunnen verhogen.

In de huisartsgeneeskundige literatuur kon geen ander onderzoek op dit gebied gevonden worden. De studie kent uiteraard beperkingen. De non-respons in de voormeting is aan de hoge kant. Verwacht mag worden dat bij een hernieuwde inventarisatiemeting met bekendmaking van het expliciete doel en met steun van de huisartsenvereniging de non-respons verkleind kan worden. Daarbij zou, in tegenstelling tot het hier beschreven onderzoek een reminder verstuurd kunnen worden. 
Een mogelijke, tweede beperking betreft de vraag of de resultaten van dit onderzoek zonder meer generaliseerbaar zijn naar andere universitaire regio's. Vergelijkbaaar onderzoek is niet gepubliceerd, zodat hierover moeilijk uitspraken te doen zijn. De onderzoekers hebben wel de verwachting dat een meer gestructureerde benadering. van huisartsen voor participatie aan onderwijs en onderzoek voor alle regio's zinvol is en dat ook in andere regio's een verband tussen voorkeuren en daadwerkelijke participatie gevonden zal worden.

Een sterke kant van onderzoek betreft het feit dat de huisartsen in het geheel niet zijn beinvloed door kennis over de follow-up. De inventarisatie in 1988 werd gedaan als onderdeel van de bekendmaking van het zogenaamde Coördinatiebureau Eerste Lijn. In de jaren na 1988 werden steeds alle huisartsen geattendeerd op nieuwe projecten via schriftelijke communicaties (de nieuwsbrief van het coördinatiebureau, het Huisartsgeneeskunde bulletin van de vakgroep en andere informatie). De uitgespoken voorkeuren van de voormeting zijn nog niet gebruikt in de tot nu toe aangewende benaderingsstrategie.

Wil concluderen dat de benaderingsstrategie in de toekomst aangepast kan worden en kan overgaan in een meer gerichte sturing van vraag en aanbod.

In dat geval moet aan de huisartsen gevraagd worden een toekomstige inventarisatieenquete niet te 'voorzichtig' in te vullen. Vanuit het vakgebied heeft cle huisarts namelijk een breed perspectief en het gevaar bestat dat de breedte van het vakgebied in de resultaten van de inventarisatie in te sterke mate wordt teruggevonden, zonder dat de eventueel bestaande voorkeur voldoende wordt benoemd. Nadrukkelijk vragen naar specifieke belangstellingen moet onderdeel zijn van een nieuwe inventarisatie. 


\subsection{Literatuur}

1

Marens FMG. Op' Roof JMH. Practical Medical Education in General Practice. Med Education 1992;26: 213-7 2

Weiden GDEM van der, Grol RWT, Knoments IA. Optimal evaluation of national cholesterol guidelines in gental practice [abstract. In: Book of abstracts WONCASMIG congress 1993, Qunlity of are in hrmily mediche/general practice, jun 13-17 1993, The Hague. Utrecht NHO, 1993:155

3

Weflen GDEM wan der, Hutren JBF, Brandenburg B]. Grol RPTM, Velden K van der. Cholestenol diagnosis and treatment in Dutch genem practice. A comparison with national guidelines. In: Velden I. van der, Bijl D, Prandenburg B. Hofstra M, Grol R. NHG-standaanden en kwaliteit van zorg in de huisartspraktik. Eind-rappont Utrecht: NHG, WOK, NTEL.

4

Wolfs GGMC, Knottinerus JA, Janiknegt RA. Prevalence and detection of micturition problems annong alderly males: a population study in 2734 men. J Urol 1994; 152: 1467-70

5

Knounemis A, Wolls GGMC, Muyrers PEM. Benigne prostathyperplasie: een probleem voor patient en muisants. Huisarts Wet $1989 ; 32(11): 420 \cdots$

6

Brueren MM, Diman GJ, Schouten B], Ree JW wan. Hypertensiediagnostiek door de huiserts: de NHG-stardaand getoetst aan de ambulante bloedidrukmeting. Ned Tijd Geneesk, $1995 ; 139(6): 276-82$

7

Snoffers HEJH, Kaser $V$, Kester A, Schouten H, Knotnerus JA Peripheral Arterial Occhsive disedse in General Praclice: the reproducibility of the Ankle-Am systolic pressure ratio. Scan J Prim Heath Care 1991; 9: 109-14

8

Stofliers HEJH, Kaiser V, Knotmerus IA. Prevalence in general practice In: Fowkes FGR Epidemiology of peripheral wascular disease. London: Springer Verlag, 1991 : 109-15

9

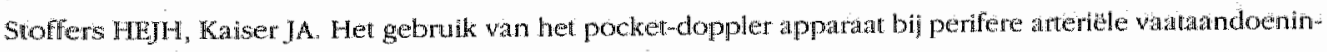
gen: een literahuronderzok. Hutsans wet 1994; 37(8): 333-8

10

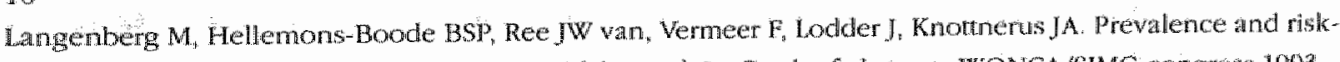
profile of atrial fibrilation in general practice labstact. In: Book of ahstracts WONCA/SIMG Congress 1993.

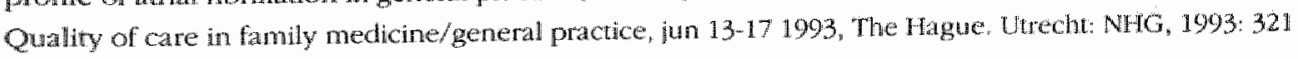

1.

Govart ThME, Dinant GJ, Areiz K, Masurel M, Sprenger MW, Knotmens, JA. Adwerse reactions to influenza

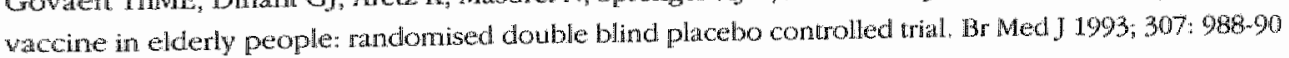

12

Gowaer ThME. Influenza bij ouderen. Proefschrift. Maastricht: Rigktuniversiveit Limburg, 1.99.

13

Rew WW wan, Pol G wan der. Efficacy and volerability of very low and anedim dose fielodipine in oldet patients with mild to moderate hypertension [submitted] 
Riften GH. Rectal bleeding, a danger signal? Proefschrift. Maastricht: Rijksuniversiteir Limburg, 1993

15

Muris JWM, Starmans R. Non acure abdominal complaints. Diagnostic studies in general practice and outpatient dinic. Proefschrift. Maastricht: Rijksuniversiteíl Limburg, 1993

16

Vierhout WPM. Het gezamenlik consult van huisarts en specialist in de eerste lijn. Proefschrift. Maastrclit: Rijhsiniversiteit Limburg, 1994

17

Grol R, Beurden van, Binkhorst T, Tomen T. Patient education in Family Practice: the Consensus Reached by Patients, Doctors and toxperts. Family Practice 1991; 2: $133-9$

18

Jansen JM, Tan LHC, Vleuten CPM van der, Grol RPTM. Toetsing, van medisch-technische varardigheden bit huilsartsen: cen vergelijking van drie verschillende methodes. In: Metz JCM, Scherpbier AJA, Houtkoop E (red) Gezond Onderwijs 2, NVMO, Nijmegen 1993: 159-63

19

Jansen JM, Tan LHC, Weuten CPM van der, Grol RPTM. Assessing technical clinical skills of general practitioners in the Netherlands: Results of a pilot project [abstract]. In: Book of abstracts WONCA/SIMG congress 1993, Quality of care in Family medicine/general practice, jun 13-17 1993, The Hague. Utrecht: NHG, $2993: 388$

\section{0}

Portegils PJM, Kran HF, Knottnerus JA, Stoffers HEJH. Wat heet somatisatie? 1. Een zoektocht uir de invernationale literatuur naar een definitie voor huisartsgeneeskundig onderzoek. Huisarts. Wei 1992; 35: 18-25,43

21

Portegijs PJM, Kràan HF, Knotmerus JA, Stoffers HEJH. Wat heet somatisatie? 2. Een antwoord uit de internationale literatuur getoest aan 19 jaar Huisarts en Wetenschap. Huisarts Wet 1992; 35: 65-9

22

Leeuwen YD van, Pollemans MC, Dusman H, Vleuten CPM van der, Grol RPTM. De huisantsgeneeskundige kennistoets constructivaliditeit en betrouwbaarheid. Filke maten meten wat? In: Metz JCM, Scherpbier AJA. How thoop B (red). Gezond Onderwijs 2, NVMO, Nijmegen 1993: 164-8

23

Leeuwen YD van, Eekhof JAH, Pollemans MC, Kramer AWM, Mol SSL. The knowledge test for general practice in the Netherlands: A consultation hour on paper falbstract. In: Book of abstracts WONCA/SIMG Congress 1993. Quality of care in family medicine/general practice, jun 13\%17 1993, The Hague. Utrecht: NHG, 1993: 307

24

Schonck RSM, Beusmans GMHI, Crebolder HFIM. Innovation in homecare for the elderly [abstract]. In: Book of abstracs WONCA/SIMG congress 1993, Quality of care in family medicine/general practice, jun 13-17 1993, The Hague. Utrecht: NHG, 1993:6

25.

Schonck RSM. Beusmans GMHI, Grol R, Mellink R, Crebolder HEJM. Een consensusmethode voor multidisciplinaire richdinontwikkeling in de thuiszorg. Kwaliteit \& Zorg 1993; 1: 135-47 


\section{Tabl 94 onderwis algeneen}

\section{Onderwijs algemeen}

Voormeting 1988 +

Total

Relatitef risico $=$

95\% confudence intervicil $=$

Pearsan

$p=$

\section{Nameting 1993}

*

$46 \quad 42$

$17 \quad 48$

63
Totaal

83

65

153

0.0011

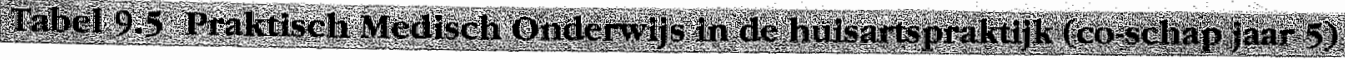

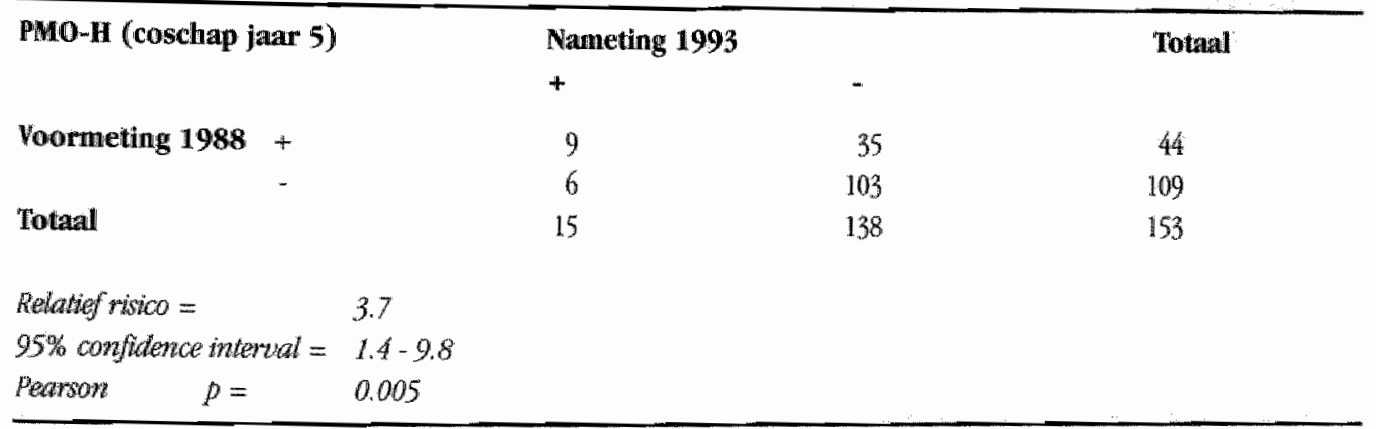

\section{Iabe19.6 Hutstartsepleiding}

\begin{tabular}{|c|c|c|c|c|c|}
\hline \multirow{2}{*}{\multicolumn{2}{|c|}{ Hutsartsopleiding }} & & \multicolumn{2}{|c|}{ Nameting 1993} & \multirow[t]{2}{*}{ Totaal } \\
\hline & & & * & - & \\
\hline \multirow[t]{2}{*}{ Woormeting 1988} & + & & 23 & 30 & 53 \\
\hline & - & & 5 & 95 & 100 \\
\hline \multicolumn{3}{|l|}{ Totanal } & 28 & 125 & 153 \\
\hline \multirow{2}{*}{\multicolumn{2}{|c|}{$\begin{array}{l}\text { Relatief risico = } \\
95 \% \text { confidence interwl }=\end{array}$}} & 8.7 & & & \\
\hline & & $3.5 \cdot 21.5$ & & & \\
\hline \multicolumn{2}{|c|}{ Pearow $\quad p=$} & 0.00 & & & \\
\hline
\end{tabular}




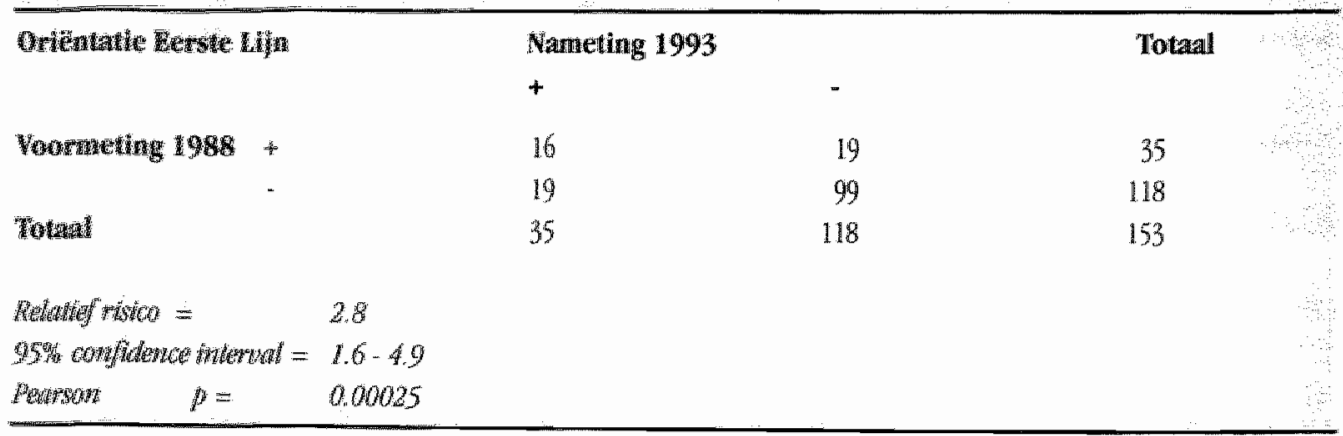

\section{Thel 9.8 onderoek al geneen}

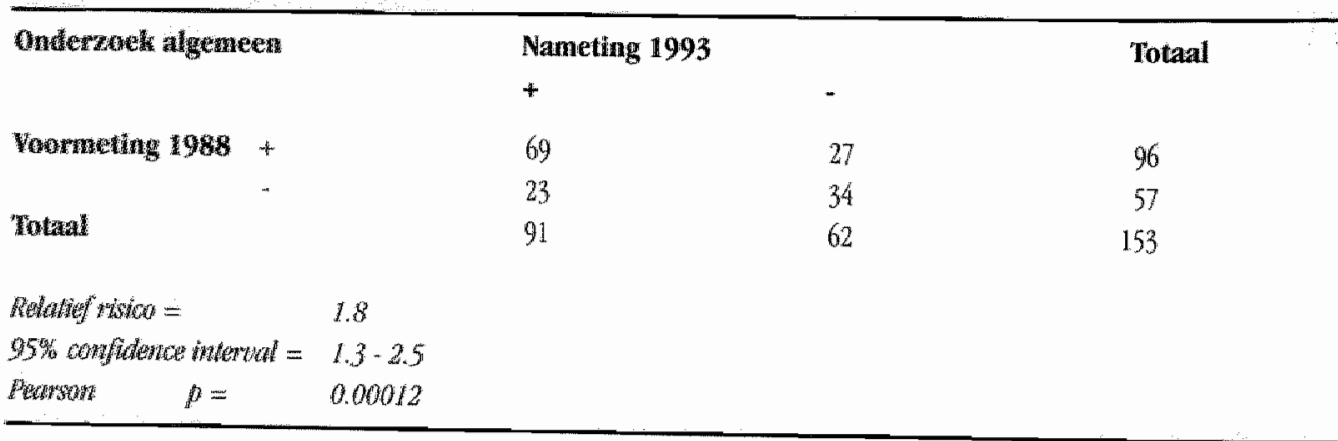

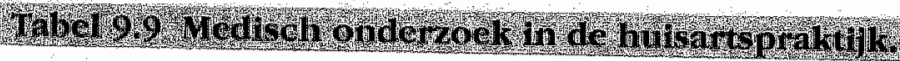

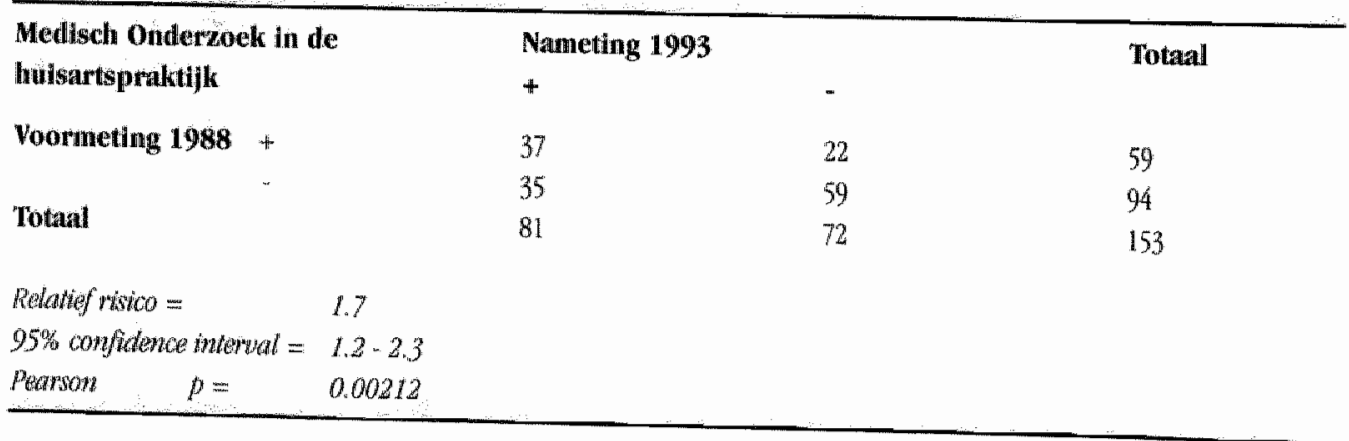




\section{Talol 9.10 functioneren van de huisarts.}

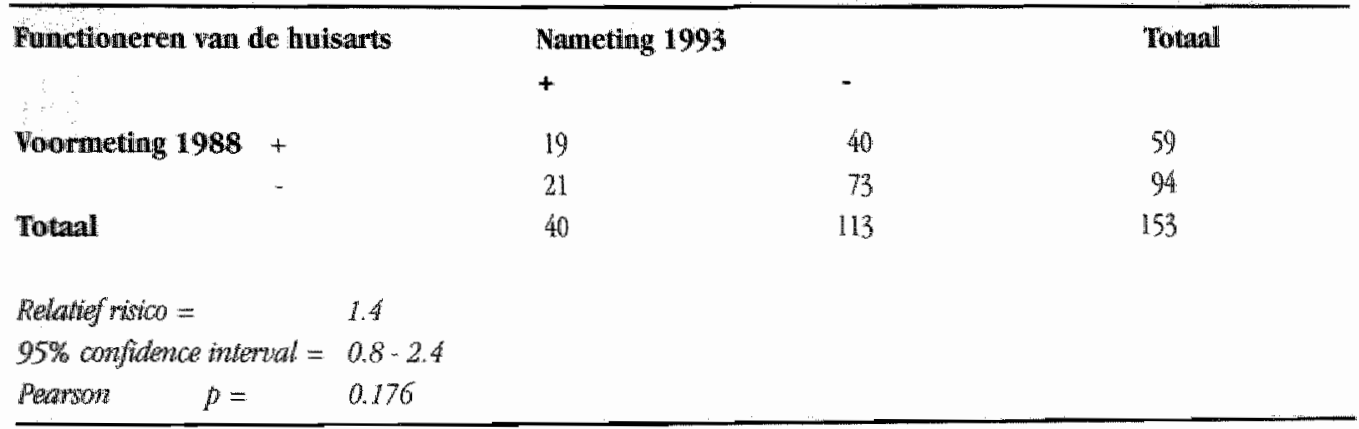




\section{ONDERZOEK NAAR MANAGEMENT-ASPECTEN}

\section{IN EEN VAKGROEP HUISARTSGENEESKUNDE}

\author{
RIV. KOCKEN
}

P.E.I.M. SMEETS-RINKENS

J.A. KNOTTNERUS
Beheerder vakgroep huisartsgeneeskunde-Rijksumiversiteit Limburg, tevens coördinator Coördinatiebureau Eerste Lijn van de Rijksuniversiteil Limburg

Algemeen research-assistent van de wakgroep huisartigeneeskunde

Hoogleraar huisartsgeneeskunde

\section{Verantwoording.}

De belangrijksse resultaten van het onderzoek zijn gepubliceerd in:

Kocken RJJ, Smeets-Rinkens PELM, Knotnerus JA. Onderzoek naar management-aspecten in een wakgroep huisartsgeneeskunde. Universiteit en Hogeschool 1992; 38(3): 136-44.

\subsection{Inleiding}

Door allerlei wettelijke kaders en richtlijnen wordt aan universitaire vakgroepen een bepaalde organisatiestructuur opgelegd. Het lijkt erop dat de wetgever grote inspraak en democratie beoogt en dat besluiten op basis van consensus tot stand moeten komen.

Ook de vakgroep huisartsgeneeskunde van de Faculteit der Geneeskunde - Rijksuniversiteit Limburg is gestructureerd volgens de wettelijke worschriften en kent dan ook een beleidsbepalend orgaan bestaande uit een zeer brede staf, een dagelijks bestuur met een hoofdzakelijk voorbereidende en uitvoerende functie en een vakgroepwoorzitter als spil in dit geheel. Met de komst van de beheerder kwam er nog een "figuur" bij, die in termen van management een bijdrage wilde leveren. Hoe wordt het management nu intern ervaren? Is er sprake van een positieve werkbeleving, resultaatgerichtheid, een juiste verdeling van bevoegdheid en verantwoordelijkheid? Hoe wordt er met informatie omgegaan en op welke wijze wordt overleg gevoerd en komen besluiten tot stand?

Dit waren enkele van de vele vragen die de onderzoekers bezighielden. Daarom werd er een onderzoek gestart onder 71 medewerkers van de vakgroep. Doel, methode en belangrijkste resultaten worden in het artikel beschreven.

De vakgroep huisartsgeneeskunde van de Rijksuniversiteit Limburg (RL) heeft in de afgelopen 5 jaar een grote inhoudelijte en organisatorische ontwikkeling doorgemaakt. De aanwezige formatie groeide tussen 1987 en 1991 van zo'n 20 Fte (full-time equivaleni) naar een niveau van ruim 60 Fte (verdeeld over 110 medewerkers). 
Alhoewel dit onderzoek geen direct verband heeft met het proces van samenwerking. van een universitaire vakgroep met het veld van praktizende huisartsen mag worden aangenomen dat de percepties van de medewerkers van de vakgroep huisartsgeneeskunde over het management ${ }^{1-5}$ van indirecte invloed zijn op de concrete invulling van de sämenwerkingsrelaties. Ben gemotiveerde en resultaatgerichte onderzoeker of docent met een zelfstandige bevoegdheid en verantwoordelijkheid zal naar alle waarschijnlijkheid sneller geneigd zijn aandacht te geven aan de samenwerking met het veld.

\subsection{Vraagstelling}

Om het noodzakelijke inzicht in de beleving van het management ${ }^{1-6}$ te verkrijgen is in de vakgroep een onderzoek gestart naar een aantal management-aspecten in de eigen organisatie. Het interne onderzoek "Management binnen de vakgroep huisartsgeneeskunde" had tot doel de actuele toestand vast te stellen wan een aantal aspecten samenhangend met het management in die groep.

De volgende aspecten werden hierbij geëvalueerd:

1. Werkbeleving en werkomgeving

2. Resultaatgerichtheid

3. Functie, functiebeeld, functie-uitoefening

4. Bevoegdheid en verantwoordelijkheid

5. Besluitvormingsprocessen en overlegstructuren

6. Informatie en informatievoorziening

7. Leiding, controle en begeleiding

De onderzoekers waren geïnteresseerd in de volgende specifieke vragen:

" Bestaan er op het gebied van de beleving van het management verschillen tussen de medewerkers met een wetenschappelijke functie enerzijds en het zogenaand niet-wetenschappelijk personeel anderzijds?

* Veranderl de perceptie ten aanzien van het management naarmate men langer werkzaam is in de vakgroep?

* Is dit tevens het geval indien men met een hogere werktijdsfactor in de vakgroep werkzaam is?

\subsection{Methode/populatie-beschrijving/respons}

Het onderzoek werd verricht door middel van een schriftelijke enquête, die verspreid werd onder die medewerkers in vaste en tijdelijke dienst, die hun werkplek in én van de 2 kantoorunits van de vakgroep hebben. De huisartsen, aangesteld bij de vakgroep, maar hun werkzaamheden primair verrichtend vanuit de eigen huisartspraktijk, werden niet ondervratagd, omdat zil gezien hun specifieke talak minder betrokken zijn bij het interne management van de vakgroep. Aangeschreven werden in totaal 71 medewerkers, waarvan er in totaal 48 behoorden tot de categorie wetenschappelijk perso- 
neel (onderzoekers, docenten e.d.) en 23 to het onderwijs- en onderzoekondersteunend personeel (secretaresses, onderzoek-assistenten e.d.).

In total respondeerden 46 medewerkers (65\%), te weten 31 leden van het wetenschappelijk personeel (respons $65 \%$ ) en 15 leden wan het niet-wetenschappelijk personeel (respons 65\%).

Wan de 46 respondenten werkten in totaal 28 medewerkers minder dan 5 jaar bij de organisatie, terwijl 18 medewerkers 5 jaar of langer waren aangesteld.

Ten aanzien van de werktijdfactor kan worden vermeld dat 13 medewerkers minder dan 0,5 Fte aangesteld waren en 33 medewerkers 0,5 Fte of meer.

De medewerkers ontvingen een anonieme vragenlijst met 36 stellingen. Op een 5 punts schaal kon worden aangegeven of men het met de betreffende stelling volledig eens, eens, noch eens noch oneens, oneens of volledig oneens was.

Va een hercodering, waabij 'volledig mee eens' 2 punten scoorde en 'volledig mee oneens -2 punten, werden per item gemiddelde scores berekend. Van gemiddelden in de rabijheid van 0 kan gezegd worden dat de geenquêteerden vrij neutraal staan ten opzichte van de stelling. Bij een gemididelde score van -2 is er volledige overeenstemming, met dien verstande dat iedereen 'volledig oneens' heeft geantwoord.

Er waren aanvullende vragen over de werktijdfactor, aantal ervaringsjaren in de eigen wakgroep en of men tot het wetenschappeliik dan well het niet-wetenschappelijk personeel behoorde.

Tenslotte was er nog gelegenheid in de vorm van open vragen opmerikingen te maken in meer algemene zin. Verschillen tussen subgroepen verden getoetst doot middel van T-toets voor verschillen tussen gemiddelden, waarbij een tweezijdige significantiedrempel van 0.05 werd gehanteerd.

\subsection{Resultaten}

\section{Werkbeleving, status en werkomgeving}

Geconcludeerd kan worden dat de medewerkers van de vakgroep goed te spreken zijn over hun werk (gemiddelde score 1,37 ) en graag bij de vakgroep werken $(1,31)$. Deze waardering staat echter in contrast met de opvattingen over de werkomgeving. $35 \%$ van de medewerkers ervart de werkongeving niet als inspirerend en motiverend, terwij $42 \%$ van mening is dat de vakgroep niet over voldoencle hulpmiddelen en voorzieningen beschikt, noodzakelijk voor de uitoefening van taken.

Met betrekking tot de mogelijkheden om zich verder te ontwikkelen bestaat een licht positief beeld. De gemiddelde score van 0,57 mag gezien de inspanningen in de vakgroep laag genoemd worden. Daarentegen bestat er grote overeenstemming over de positieve waarde van de flexibele werktijdregeling (gemiddelde score 1,36).

Dat er in een wetenschappelijk bedrijf statusverschillen worden ervaren tussen het wetenschappelijk personeel (WP) en de personeelscategorie "onderwijs- en onderzoek-ondersteunend personeel" (OBP) was te verwachten.

De gemiddelde score van 0,40 geeft een lichte tendens in de richting van "mee eens" aran. Alhoewel status-verschillen door het niet-wetenschappelijk personeel meer worden ervaren (score 0,79) dan door het wetenschappelijk personeel (score 0,23) is er geen sprake van een significant verschil $(\mathrm{p}=0,11)$ 


\section{Resultaatgerichtheid}

In de afgelopen jaren is er in toenemende mate aandacht gevraagd voor het rotale resultaiat van de vakgroep, meetbaar in onderwijskwaliteit (rendement e.d.) en outputciffers in het onderzoek (publikaties, citatie-quotes e.d.).

De verwachting bestond dat deze resultaatgerichtheid ook voor de individuele medewerkers consequenties zou noeten hebben. De medewerkers geven aan een sterke behoefte te voelen om goede resultaten te halen (score 1,48 ) en zich maximaal in te spannen om die beoogde resultaten te behalen $(1,54)$.

Toch zijn er nog 16 medewerkers (34\%) die van mening zijn dat middelmatigheid in de vakgroep geaccepteerd is.

\section{Functie, functiebeeld en functie-uitoefening}

Een belangrijke factor van de functie-uitoefening is de duidelijkheid over de eisen die aan cle functie worden gesteld. De functie-eisen worden door de medewerkers als duidelijk ervaren $(1,02)$. Ook de planning van de werkzaamheden wordt in voldoende mate besproken $(1,02)$, terwijl er regelmatig meer uren gewerkt wordt, dan waarvoor men betaald wordt $(1,13)$. De medewerkers krijgen regelmatig complimenten over de behaldile resultaten $(0,52)$. Er is weinig stimulans om meer risico (op het maken van fouten of het overtreden van de eigen verantwoordelijkheidsgrens e.c.) te nemen op de momenten dat het werk af moet $(0,12)$.

\section{Bevoegdheid en verantwoordelijkheid}

De medewerkers zijn van mening over voldoende bevoegdheden te beschikken om het werk goed te doen $(1,20)$, terwijl men in hoge mate zelfstandig beslissingen kan nemen $(1,26)$. Men voelt een grote persoonlijke verantwoordelijkheid voor de eigen werkzaamheden $(1,13)$ en wordt op die verantwoordelijkheid ook aangesproken $(1,26)$.

\section{Besluitvormingsprocessen en overlegstructuren}

Dit ondercleel van de enquête leverde voor de vakgroep negatieve resultaten op. De medewerkers van de vakgroep vinden dat de vakgroep voor het nemen van besluiten veel tijd noflig heeft $(1,04)$, terwijl de kwaliteit van de besluiten als relatief laag wordt beschouwd $(0,29)$. De vergaderfrequentie levert een tamelijk diffurus beeld op; $36 \%$ is van mening dat er te veel vergaderd wordt, terwijl $19 \%$ het hiermee niet eens is. De overige medewerkers spreken geen mening uit (45\%).

Ook de waarde van de vergaderingen van de vaste commissies in de vakgroep is onderzocht. De researchgroep-vergaderingen worden als nuttig en zinvol ervaren in relatie tot de tijdsinvestering, hetgeen van de onderwijsgroep-vergaderingen niet gezegd kan worden. Het bezoeken van de vergaderingen van het Algemeen Bestuur (volgens het wettelijke kader het besluitvormend orgaan van de vakgroep) wordt als weinig zinvol ervaren in relatie tor de tijd, die het kost $(0,41)$, terwijl men er naar neigt te oordelen dat het Algemeen Bestuur te kort schiet als besluitvormend orgaan van de vakgroep $(0,75), 40 \%$ Van de medewerkers is van mening dat de besluiten genomen worden door een kleine selecte groep personen binnen de vakgroep.

\section{Informatie en informatievoorziening}

De informatievoorziening naar individuele medewerkers (schriftelijk en mondeling) wordt als net voldoende ervaren $(0,30)$, terwijl men in ruim voldoende mate op de
hoogte wordt gesteld van de behaalde resultaten $(1,02)$. 


\section{Leiding, controle en begeleiding}

In elke matrixorganisatie bestaat het gevaar dat een meerhoofdige leiding onvoldoende duidelijkheid biedt. Voor de medewerkers van de vakgroep blijkt dit geen probleem; het is vrij duidelijk wie in directe zin leiding geeft $(1,00)$.

De begeleiding wordt niet als onvoldoende ervaren $(-0,51)$, terwiil de werkzaamheden niet overdreven, maar wel regelmatig gecontroleerd worden $(0,27)$.

\section{Vergelijking wetenschappelijk versus ondersteunend personeel}

Belangrijk onderdeel van het management-onderzoek betrof de vaststelling van eventuele verschillen qua opvatting tussen het wetenschappelijk en het ondersteunend. personeel. In tabel 10.1 worden de significante verschillen weergegeven.

Voorzichtig mag geconcludeerd worden dat het onderwijs- en onderzoekondersteunend personeel in mindere mate verantwoordelijk wordt gesteld voor de resultaten en. minder gestimuleerd wordt risico's te nemen. Het wetenschappelijk personeel is meer dan het ondersteunend personeel van mening dat het algemeen bestuur als besluitvormend orgaan wan de vakgroep tekortschiet. De vergaderfrequentie wordt door het wP (Wetenschappelijk Personeel) niet te hoog gevonden. Tenslotte staat het WP vrij neutraal tegenover de mening dat middelmatigheid in de organisatie geaccepteerd wordt, in tegenstelling tot het ondersteunend personeel, die vindt dat dat wel het geval is.

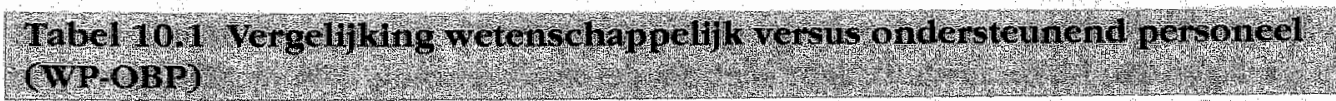

Onderwerp

Middelmatigheid word ntet geaccepteerd in dit bedrijf

U spant u maximaal in on het beogde rosultat te wehaten

U wordt gestimuleerd om meer risico te nemen als het werk af moet

U heeft een persoonlijke verantwoordeligkheid poor de resultaten

Er wordt in het algemeen te veel owertegd

U werkt regehriatig meer uren dan waarvoor u betaald wordt

Het Algemeen Bestuur schiet als beshitwormend orgatan wan de valkgroep tekort

Gemiddelde score
WP $(\mathbf{n}=31)$

0.32

0.67

1.87

0.004

1.39

0.40

.0 .64

0.01

1.48

0.40

0.002

$-0.03$

0.85

0.006

1.48

0.36

0.0013 


\section{De invloed van de werktijdfactor}

In de organisatie wordt op grote schaal part-time gewerkt; van de respondenten werkt $28 \%$ minder dan 0,5 Fte (full-time) equivalent ( 1 full-time equivalent $=100 \%$ werktijdfactor), terwijl slechts $33 \%$ een full-time aanstelling heeft. Het is dan ook belangrijk na te gaan of de werktijdfactor van invloed is op de mening over de diverse management-aspecten in de vakgroep. Uit het onderzoek blijkt dat de medewerkers, die meer dan 0.5 Fte in de vakgroep werkzaam zijn, in het algemeen negatiever staan ten opzichte van de invulling van het management; zij zijn sterker van mening dat de valkgroep voor het nemen van besluiten te veel tijd nodig heeft, dat het Algemeen Bestuur als besluitvormend orgaan te kort schiet en dat de informatievoorziening naar individuele medewerkers niet optimaal is.

\section{De invloed van de werkervaring in de vakgroep}

De vakgroep huisartsgeneeskunde kende de afgelopen jaren een stormachtige groei: $61 \%$ van de respondenten geeft aan minder dan 5 jaar bij de vakgroep te werken, terwijl slechts $39 \%$ langer dan 5 jaar in de vakgroep werkzaam is.

Het blijkt dan ook van evident belang na te gaan of de scores veranderen naar mate men langer in de vakgroep aangesteld is. Met elkaar werden vergeleken zij clie langer en zij die korter dan 5 jaar in de vakgroep werkzaam waren.

Uit de resultaten kan geconcludeerd worden dat de medewerkers, die langer dan 5 jaar werkzaam zijn minder tevreden zijn over de informatievoorziening en de mate waarin de planning van de werkzaamheden met hen besproken wordt. Ook de begeleiding, alhoewel niet onvoldoende genoemd, scoorde bij de langer werkenden significant lager dan bij de medewerkers met minder werkervaring. De omgeving waarin gewerkt wordt, wordt minder inspirerend en motiverend genoemd naarmate men langer in de organisatie werkzaam is. De waardering voor hetgeen gerealiseerd is neemt geleidelijk aan af narmate men langer in de organisatie werkzaam is.

Tenslotte zijn de medewerkers met grotere interne werkervaring in hogere mate ontevreden over het Algemeen Bestuur als besluitvormend orgaan. 
In tabel 10.2 en 10.3 worden respectievelijk de meest positieve en de als negatief ervaren management-onderdelen beschreven.

\section{Tabel 10.2 Top 7 Positieve management envaringen}

$\mathrm{n}=46$

\begin{tabular}{|c|c|c|}
\hline 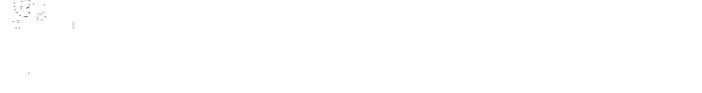 & $\begin{array}{l}\text { Scores totale groep } \\
\text { Gemiddelde score }\end{array}$ & Standaard-fleviatie \\
\hline Uspant u maximaal in on het beoogde resultaat te behalen & 1.54 & 0.09 \\
\hline Wheft een sterke behoefte om goede resultaten te behalen & 1.48 & 0.09 \\
\hline U bent en thousiast over uw werk & 1.37 & 0.11 \\
\hline Uwindt het plezierig te werken in een organisatie met & & \\
\hline Mexibele werktijden & 1.36 & 0.12 \\
\hline U werkt graag bij de vakgroep & 1.31 & 0.10 \\
\hline $\begin{array}{l}\text { U heeft de bewoegdheid zelf beslissingen te nemen die nood- } \\
\text { zakelijk zijn on uw werkzaambeden uil te voeren }\end{array}$ & 1.26 & 0.11 \\
\hline U wordt werantwoondelijk gesteld voor uw eigen werkzaamheden & 1.26 & 0.10 \\
\hline \multicolumn{3}{|l|}{ Gewniddelde scores op even viffoundschal, variërond wan } \\
\hline$-2 \quad$ - in bet gehel niet mee eens & & \\
\hline lot $+2 \quad-$ volledig mes eents & & \\
\hline
\end{tabular}

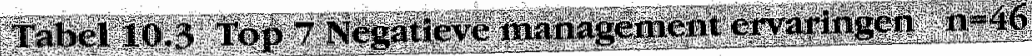

\begin{tabular}{|c|c|c|}
\hline & $\begin{array}{l}\text { Scores totale groep } \\
\text { Gemiddelde score }\end{array}$ & Standaarddeviatie \\
\hline Woor het nemen van besluitten heeft de vakgroep veel lijd nodig & 1.04 & 0.16 \\
\hline $\begin{array}{l}\text { Het Aigemeen Bestuur schiet als besluitvormend orgaan van de } \\
\text { vakgroep tekort }\end{array}$ & 0.75 & 0.13 \\
\hline Besluiten worden genomen door zen kJeine groep in de vakgroep & 0.69 & 0.13 \\
\hline De scheiding qua locatie is problematischer dan verwacht & 0.47 & 0.17 \\
\hline $\begin{array}{l}\text { Deelname aan de Onderwijsgroepvergadering kost veel tijd in } \\
\text { relatie tot de zin en het nut ervan }\end{array}$ & 0.47 & 0.13 \\
\hline De omgeving waarin u werkt vindt u inspyirerend en motiverend & 0.43 & 0.16 \\
\hline $\begin{array}{l}\text { Deelname aan de stafvergadering (AB) kost u veel tijd in relatie } \\
\text { tot de zin en het nut ervan }\end{array}$ & 0.41 & 0.15 \\
\hline $\begin{array}{ll}-2 & - \text { in bel gebeel miat mee cens } \\
\text { wot }+2 & - \text { tolledig mee cens }\end{array}$ & & \\
\hline
\end{tabular}




\subsection{Discussie}

De medewerkers van de vakgroep huisartsgeneeskunde werken graag bij deze organisatie en zijn goed te spreken over hun werk. Er bestaat een sterke behoefte om goede resultaten te behalen en men meent in de regel een maximale inspanning te leveren on de beoogde resultaten te behalen. Ook het flexibele beleid inzake de werktijden wordt als zeer belangrijk en positief ervaren. De functie-eisen zijn voldoende duidelijk en de medewerkers hebben voldoende bevoegdheden om hun werk goed te doen. De individuele mectewerker voelt en krijgt voldoende verantwoordelijkheid binneri het eigen takgebied. Begeleiding en controle worden redelijk positief ervaren. Punt van zorg is het onderwerp "besluitvormingsprocessen" en overlegstructuren". Het nemen van besluiten vraagt naar het oordeel van de respondenten veel tijd, terwijl teggelijkertijd geconstateerd wordt dat de kwaliteit van die besluiten niet beter is. Het Algemeen Bestuur schiet, met name in de ogen van het wetenschappelijk personeel, tekort als besiuitvormend orgaan van de vakgroep en deelname aan de vergadering van het Algemeen Bestuur wordt dan ook als weinig zinvol beschouwd in relatie tot de tijd die her bijwonen van deze vergaderingen kost. $40 \%$ Van de medewerkers is van mening dat de besluiten genomen worden door een kleine selecte groep personen binnen de vakgroep. Naarmate medewerkers langer bij de vakgroep werken stellen zij hogere eisen aan de aspecten planning, informatievoorziening, begeleiding en motivatie en inspiratie op de werkplek. Naarmate men een hogere werktijdfactor heeft ( $>0,5$ Fte aanstelling bij de vakgroep) wordt negatiever gedacht over de onderwerpen besluitvaardigheid en informatievoorziening. Er blijken verschillen te zijn in perceptie en beleving van het management tussen het wetenschappelijk en het ondersteunend personeel. Met name het niet-wetenschappelijk personeel is van mening dat middelmatigheid redelijk geaccepteerd is in de vakgroep en dat er in het algemeen te veel tijd wordt besteed alan vergaderingen en overleg. Voorts blijkt dat deze personeelscategorie in mindere mate verantwoordelijkheid krijgt toebedeeld voor de eigen werkzaamheden en minder wordt gestimuleerd om risico's te nemen. Er wordt door beide categorieën in lichte mate een statusverschil ervaren tussen het wetenschappelijk en het ondersteunend personeel.

De volgende aanbevelingen kunnen op basis van dit onderzoek worden geformuleerd: 1

De vakgroep zal zich moeten beraden over de waarde van het Algemeen Bestuur (als besluitvormend orgaan)

2

Ook over het hele besluitvormingsproces als zodanig moet worden nagedacht 3

De informatievoorziening naar individuele medewerkers toe kan verbeterd worden. 


\subsection{Literatuur}

$1:$

Mackenzid RA. Mamagement Process. Harvard Business Review, 6, 1969

2

Botter CH. Industrie en onganisatic, een verkenningstocht. Kinder/ NTVE, 1970 3

Keuning D, Eppink Dy. Management en organisatie: Theorie en roepassing. H.E. Stenfert Kroese BV. Leiden/Antwerpen, 1985

4

Scapens RW. Management Accounting: A review of tecent developments. McMillan Echouthon Lt. Unined Kingdiom, 1987

5

Schiemat CJ. Beheersing van bedrifsprocessen. H. E. Stenfer Kroese. Leiden, 1975 


\section{HOOFDSTUK 11}

\section{ALGEMENE BESCHOUWING EN}

\section{AANBEVELINGEN}

\subsection{Inleiding}

De samenwerking van universiteiten met het huisartsgeneeskundig veld verloopt in principe langs twee parallelle lijnen, academisering en affiliatie. 'Academisering' betekent dan de gestructureerde / geïnstitutionaliseerde samenwerking tussen universiteit en huisartspraktijken, waarbinnen onderling samenhangende en vooraf overeengekomen activiteiten plaatsvinden ten behoeve van (de integratie van) wetenschappelijk onderwijs en onderzoek en patientenzorg.

De voor deze samenwerking noodzakelijke infrastructuur wordt vervolgens her 'academiseringsnetwerk' genoend.

Academisering kan in historisch perspectief op twee manieren gezien worden. De eerste academiseringsvorm betreft de opname van de dicipline huisartsgeneeskunde in het universitaire bestel, waarbij pas in 1977 bij alle Nederlandse universiteiten een leerstoel huisartsgeneeskunde ingesteld was. De tweede academiseringsvorm betreft het proces van structurering van de samenwerking tussen universiteit en huisarts voor de uitvoering van onderwijs en onderzoek enerzijds en voor de noodzakelijke innovatie en kwaliteitsbewaking van de patiëntenzorg anderzijds. Deze tweede vorm wordt bestudeerd in dit proefschrift.

'Affiliatie' wijkt in zoverre af van academisering, dat bij affiliatie de nadruk niet direct ligt op de integratie van onderwijs of onderzoek met de patiëntenzorg, maar meer op de uitvoering van huisartsgeneeskundig onderwijs en onderzoek op her gewenste kwalitatieve niveau. Er is een verschil in omvang, intensiteit en continuiteit van de samenwerking tussen de universiteit en de geaffilieerde huisarts(praktijk). De gemaakte afspraken gelden doorgaams voor een specifiek onderwijs- of onderzoeksproject en slechts voor de duur van dat project (variërend van 1 tot 3 jaar). Dat laat onverlet dat vele 'affiliatie-huisartsen' langdurig en op een kwalitatief hoog niveau aan diverse projecten hun bijdrage verlenen of hebben verleend.

Voor elke klinische, universitaire vakgroep is het belangrijk op een structurele wijze toegang te hebben tot het eigen veld van gezondheidzorg. Dat geldt ook voor het vakgebied huisartsgeneeskunde. Zonder directe toegankelijkheid van het huisartsgeneeskundige veld van praktizerende huisartsen is de uitvoering van (praktisch medisch) onderwijs en wetenschappelijk onderzoek onmogelijk.

Vanaf de tachtiger jaren hebben de Nederlandse vakgroepen huisartsgeneeskunde dan ook aandacht gehad voor dit onderwerp. Ervaringen zijn opgedaan met diverse typen van samenwerking, variërend van universitaire groepspraktijken tot incidentele samenwerkingsvormen. Toch blijkt dat de academisering van de huisartsgeneeskunde nog steeds niet een positie heeft gekregen vergelijkbaar met de academisering van de 
intramurale, klinische vakgroepen. Op enkele plaatsen, zoals aan de Rijksunversiten Limburg zijn evenwel goede resultaten behaald, die wellicht een exemplarische functie kunnen hebben voor overeenkomstige ontwikkelingen bij andere vakgroepen huisartsgeneeskunde.

De samenwerking tussen deze twee partijen (universiteit enerzijds en praktizerende huisarts anderzij(s) vraagt in toenemende mate om een professionele benadering: waarin verbetering van afstemming, coördinatie en organisatie kernbegrippen zijn.

Dit proefschrift gaat dieper in op de wijze waarop de samenwerking tussen universiteit en huisarts gestalte kan krijgen en aan welke aspecten aandacht moet worden gegeven. Naast een beschrijving van de historische ontwikkeling van het vakgebied in het algemeen en de academische samenwerking tussen universiteit en huisarts in het bijzonder, wordt een case-studle gepresenteerd van het Huisartsgeneeskundig Academiseringsnetwerk Maastricht (HAM). Tevens worden modellen aangereikt voor enerzijds de academisering van de huisartsgeneeskunde en anderzijds de werving van zogenaamde affiliatie-praktijken. In deze modelen is de belangrijkste literatuur op dit terrein aangevuld met de lokale ervaringen en bevindingen.

Tanslotte worden 5 studies gepresenteend met de volgende onderwerpen:

- Onderzoek naar de ontwikkeling van huisartsgeneeskundige academiseringsnetwerken in Nederland; wat is het doel, de definitie en de omschrijwing van zo'n netwerk?

- Onderzoek naar inhoud, proces en uitkomst van de academisering van de huisartsgeneeskunde van de Rijksuniversiteit Limburg.

- Het oordeel van huisartsen over deelname aan wetenschappelijk onderzoek.

- Onderzoek naar management-aspecten in een vakgroep huisartsgeneeskunde.

- Planning en coördinatie van onderwijs en onderzoek in huisartspraktijken; volgt de huisarts bij participatie aan universitaire projecten de opgegeven voorkeursgebieden?

De algemene beschouwing is als volgt opgebouwd.

Na deze inlleiding volgt een epicrise, waarin de belangrijkste bevindingen op hoofdlijnen en in onderlinge samenhang besproken worden. Verwacht wordt dat deze van belang kunnen zijn voor de diverse Nederlandse universiteiten. Vervolgens wordt een korte methodologische beschouwing gegeven, waana de belangrijkste conclusies worden gepresenteerd. Tenslotte volgen de aanbevelingen voor de toekomst, waarbi) ook word ingegaan op mogelijk toekomstig onderzoek op het terrein van de academisering en affiliatie van de huisartsgeneeskunde.

\subsection{Epicrise}

Een van de vakgroepen huisartsgeneeskunde, namelijk die van de Rijksuniversiteit Limburg heeft vanaf zijn oorsprong aandacht besteed aan de samenwerking met de huisartsen in cle regio. Ook de universitaire besturen hebben steeds deze noodzark onderkend.

Het basisdocument van deze universiteit, de zogenaamde basisfilosofie', uit 1972 beschrift dat een medische faculteit haar doelstellingen ontleent aan de gezondheidszorg en daarnaast ook het systeem van de gezondheidszorg zou moeten beînvloeden doordat ze door wetenschappelijk onderzoek en experiment bijdraagt aan een zo goed 
mogelijke structuur en werkwijze wan de gezondheidszong. Academisering wan het huisartsgeneeskundig veld wordt hiervoor noodzakelijk geacht.

In de tachtiger jaren, meer specifiek vanaf het moment dat het symposium "Waculteit en Eerstellin" (Maastricht, november 1980) georganiseerd werd, kreeg de landelijke bellangstelling voor het onderwerp samenwerking en academisering in de huisartsgeneeskunde nituwe impulsen. Dat gold ook voor de Rijksuniversiteit Limburg.

De samenwerking van de vakgroep huisartsgeneeskunde aldaar met het huisartsgemeeskundige veld is vervolgens van de grond gekomen. Naast incidentele samenwerking ten behoeve van één specifiek onderwijs- of onderzoeksproject, ook wel affiliatie genoemd, is wanaf 1987 een begin gemaakt met het tot stand brengen van een gestructureerd academiseringsnetwerk.

\section{Affiliatie-samenwerking}

Affilatie-samenwerking is gerealiseerd met circa $70 \%$ van de huisartsen in de universitaire regio (Limburg en Zuid-Oost Brabant). Dit betekent dat ruim 300 huisartsen op enigerlei wijze participeren aan activiteiten, geinitieerd vanuit de vakgroep huisartsgeneeskunde Maastricht.

Een dergelijke samenwerking kont niet zo maat tot stand. Het vraagt grote inspanningen van zowel een universitaire vakgroep als van de huisartsen. In de samenwerking tussen uniwersiteit en huisarts kan gebruik gemaakt worden van een gepresenteerd model "Werving van affiliatie-praktijken". Dit model mede gebaseerd op de internationale literatuur op dit terrein en aangevuld met de ervaringen en bevindingen aan de Rijksuniversiteit Limburg, kent een gefaseerde aanpak, bestaande uit de voorbereidingsfase, de acceptatiefase, de wervingsfase, de uitvoeringsfase en de nazorgfase.

Een vereiste is de realisatie van een onderwijs- en onderzoeksprogramma dat goed a ansluit op de behoeften en mogelijkheden van de huisartsen. Naast de interesse van de huisarts voor de onderzoeksvraagstelling of het onderwijsproject is ook de verwachte belasting voor de huisarts zelf en de patiënten een belangrijk iten in de afweging van de huisarts om deel te nemen aan een specifieke activiteit.

Een redelijke vergoeding (Fl. $50=$ tot $F 1.100=$ per un extra tijdsinvestering) van de bijdragen van de huisartsen wordt zowel door de huisartsen zelf als door de universtteit noodzakelijk gevonden evenals een goede informatievoorziening, vootat, tijdens en na afloop van het project. In het algemeen wordt door huisantsgeneeskundige valkgroepen rekening gehouden met deze aspecten. De huisartsen geven namelijk aan dat ze tijdens de looptijd van het onderzoek op adequate wijze van informatie worden voorzien en dat de onderzoekers hun afspraken correct nakomen. De participatie aan het onderzoek heeft geen onacceptabele consequenties voor de doktersassistent(e) en de huisarts (en de assistent(e) worden door de onderzoeker in voldoende mate gemotiveerd. Helaas blijkt dat de informatie die de huisants vooraf ontwangt, vaak nog onvoldoende wordt gevonden. Een goede afweging kan hierdoor niet of nawwelijks worden gemaakt. Tijdens de looptijd van het project wordt met de participerende huisarts regelmatig gecommuniceerd. Naast schriftelijke communicatie is een regelmatig bezoek aan de praktijk een goede mogelijkheid de huisarts te informeren en te motiveren.

Wa afloop van het project moeten de buisartsen adequat geinformeerd worden over de uitkomsten van het project. Dit kan zowel in de vorm wan schriftelijk materiaal als 
door middel van een woorlichtingsbijeenkomst. Ahankelijk van de geleverde bijdrage is het zinvol de huisarts(en) met naam te noemen in het eindprodukt.

\section{Academisering huisartsgeneeskunde}

De vakgroepen huisartsgeneeskunde in Nederland hebben, meer dan bijvoorbeeld de academische afdelingen in de ziekenhuizen, gedurende vele jaren gezocht naar een theoretisch onderbouwd model, dat niet alleen bij de universiteiten en bij de beroepsgroep, thar ook bij de andere partners (ziekenfondsen, overheden, NHG, LHV enz) op steun kon rekenen. Dat blijkt onder meer uit de vele nota's die gewijd zijn an noodzak van academisering van de huisartsgeneeskunde. Op sommige plaatsen zin husartsartspraktijken in eigendom gekomen van de betreffende universitaire vakgroep huisartsgeneeskunde en kreeg de academisering op deze wijze gestalte. Op andere plaatsen werd naar anleiding van een concreet onderzoek- of registratieproject de opbouw van een netwerk gestart. Het realiseren van één acudemiseringsnetwerk ten behoeve van de uitvoering en verdere ontwikkeling van onderwijs, onderzoek en patientenzorg bleek moeilijk realiseerbaar. Een belangrijke reden hiervoor kan gevonden worden in het ontbreken van voldoende financiele middelen om een dergelijk metwerk tot stand te brengen en te continueren.

Voor huisartsgeneeskundige vakgroepen is academisering evenwel noodzakelijk. omdat er opleidingsplaatsen en ondenzoeksparticipatie gezocht worden en omdat een vakgroep zonder concrete binding met het directe gezondheidszorg-veld als ongeloofwaardig en onaantrekkelijk wordt beschouwd. De huisarts voelt in sommige gevallen een innerlijke behoefte om te academiseren, enerzijds om zijn eigen wetenschappelijk niveau the verhogen, anderzijds om naast de reguliere patiëntenzorg ook met lets anders' en op een ander abstractieniveau bezig te zijn. Verdere ontwikkeling van het nog relatief 'jonge' vakgebied der huisartsgeneeskunde is voor beide partijen een belangrike motivatie. Tensilotte participeren veel huisartsen ondat zij een positieve invloed op de kwaliteit van de patiëntenzorg verwachten.

Tijdens de opbouw van geacademiseerde netwerken huisartsgeneeskunde is het wan belang andacht te besteden aan de wijze waarop de te academiseren huisartsen geselecteend worden. Zowel het gepresenteerde landelike als het lokale onderzoek geven an dat het voorkeur verdient de selectie te laten plaatswinden door een delegatie bestande ut praktizerende huisartsen en medewerkers van de vakgroep huisartsgeneeskunde. De belangrijkste selectie-criteria zijn de aantoonbaar gemaakte motivatie voor deelname aan het netwerk, evenals de opgedane (wetenschappelijke en didaktische) erwaring. De praktifk van de huisarts moet voorts geautomatiseerd zijn (dan wel worden) en de huisarts werkt volgens het geformuleerde basistakenpakket en onderschrijt het door het NHG ontwikkelde standaardenbeleid. Ook de bereidheid tot onderlinge toetsing wordt belangrijk gevonden.

In het netwerk hebben universiteit en huisarts idealiter een gelijkwaardige positie. Het is opvallend dat de landelijke enquête suggereert dat deze gelijkwaardigheid het best gerealiseerd kan worden door de huisartsen officieel aan te stellen bij de universiteit. De huisartsen en de stafleden van het Huisartsgeneeskundig Academiseringsnetwerk Maastricht (HAM) zijn echter meer 'indifferent' ten opzichte van de gedachte dat gelijkwardigheid gerealiseerd wordt door de aanstelling van de huisarts bij de universiteit. Een vergelijkbaar verschil wordt gevonden bij de noodzaak de samenwerking in de vorm van contracten vast te leggen. Landelijk is 93\% van de respondenten van mening dat contracten noodzakelijk zijn, terwijl lokaal (te Maastricht) een neutralere mening 
wordt geformuleerd over de noodzaak van contracten. Mogelijk is het zo dat naarmate de partijen langer daadwerkelijk met elkaar samenwerken minder gewicht wordt gegeven aan formele zaken als contracten en aanstellingen bij de universiteit. De opgebouwde relatie en het gerealiseerde vertrouwen zorgen dan voor de balans in het netwerk.

Daar waar landelijk een voorkeur bestaat voor een netwerk bestaande uit 5 tot 15 huistrispraktijken, wordt in het HAM het gerealiseerde netwerk van 30 praktijken niet te groot gevonden in termen van optimale afstemming en communicatie.

De bijdragen van de huisartsen aan het netwerk kunnen vergoed worden door concrete betaling van de prestatie of door nuil van menskraclat waarbij de vakgroep medewerkers (partieel) inzet in de huisartspraktijk, waardoot de gevestigde huisarts nimte krijgt om zich bezig te houden met academische taken.

Het opleidingsprogramma voor geacademiseerde huisartsen zou kunnen bestaan uit opleidingen op het gebied van automatisering en registratie van patientgegevens, (praktijk)management met name time-management, methodologie, statistiek en didaktiek voor (huisarts)opleiders.

Een belangrijk knelpunt blifft het verschil in honoreringsstructuur tussen de gezondheidszorg en de universiteit. Tevens lukt het de huisarts niet altijd de gewenste academische tijd daadwerkelijk in te plannen en word bij calamiteiten in de regel prioriteit gegeven aan de dagelijkse patièntenzorg. Deelname aan academiseringsnetwerken leidt weliswaar tot organisatorische praktijkproblemen, maar de huisartsen van het HAM zijn, op grond van hun ervaring, van mening dat de meeste van deze problemen door de huisarts zelf op adequate wijze zijn opgelost. Verdere verfijning van de coördinatie en de inhoudelijke afstemming van onderwijs en onderzoek op de praktische gezondheidszorg blift echter gewenst.

De huisartsen denken wel beter als huisarts te functioneren door hun deelname aan het academiseringsnetwerk.

Momenteel bestaat het Huisartsgeneeskundig Academiseringsnetwerk Maastricht (HAM) wit 30 huisartsgeneeskundige settings, waarin in totaal 83 huisartsen werkzaam zijn. Tussen de partijen in het netwerk, de universiteit en de husartspraktijken, zijn contracten afgesloten, warin de samenwerking op hoofdlinen stata beschireven. Daarnaast wordr jaarlijks een inhoudelijk werkplan vastgesteld. Eeri dagelijks bestunr academisering, bestaande wit netwerk-huisartsen en medewerkers van de vakgroep huisartsgeneeskunde van de universiteit, zal geleidelijk de rol van de portefeulllehouder academisering en de beheerder op dit terrein ovememen en ziet derhalve toe op de verdere ontwikkeling van het netwerk.

Naast de regelmatige bilaterale contacten tussen de vakgroep en de praktiken, vindt er in ieder geval jaarlijks een formeel overleg plats. In dit overleg wordt de uitwoering wan het lopende werkplan kritisch geèvalueerd en het werkplan voor het wolgende kalenderjaar besproken. De huisartsen geven overigens aan een regelmatiger formeel contact wenselijk te vinden.

In het netwerk is sprake van een zogenaande interorganisationele samenwerking, een samenwerking tussen twee organisaties die slechts ten aanzien van enkele aspecten samenwerken. Het newwerk is het geraamte van deze samenwerking. Belangrijkste kenmerk van het nerwerk is een volledige gelijkwaardigheid tussen de beide partijen. De levenswatbatheid van de samenwerking kan beschreven worden vanuit twee theorieèn, de ruil-en de coalitietheorie. Voor het Hutsartsgeneeskundig Academi- 
seringsnetwerk Maastricht (HAM) zijn beide theorieên van toepassing. De rultheorie omdat de academiseringsrelatie voor beide partijen iets oplevert dat zonder die relatie niet zou kunnen. De betekenis van de coalitietheorie is minder direct zichtbaar. Toch moet men zich afvragen of de relatie niet ook gezocht en gevonden wordt om als coalitie sterker te kunnen optreden tegen mogelijke bedreigingen van de huisartsgeneeskunde bijvorbeeld van de kant van de overheid (zo werd in het rapport Dekker destijds de 'zeeffunctie' van de huisarts op de helling gezet en hebben de hoogleraren huisartsgeneeskunde en de huisartsorganisaties zich hiertegen met succes verzer) of de intramuale zorgorganisaties (zo is destijds de opheffing van de vakgroep huisartsgeneeskunde te Leiden door faculteitsbestur en Academisch Ziekenhuis Leiden mede voorkomen door eensgezind optreden van de vakgroep en de regionale huisartswereniging). in de afgelopen jaren heeft in het HAM de nadruk gelegen op de implementatie van onderwijs en onderzoek in de deelnemende huisartspraktijken, de gemeenschappelijke ontwikkeling wan nieuwe projecten en op het realiseren van een steekproefkader van ca. 80.000 patiènten in het Registratienet Huisartspraktijken. Het grote aantal projecten dat de afgelopen jaren geburik heeft gemaakt van het HAM toont het belang van een clergelijk netwerk aan. Nog meer wordt dit belang geaccentueerd door het aanzienlijke aantal wetenschappelijke vraagstellingen dat vanuit de geacademiseerde huisartsen zelf in samenwerking met de universiteit tot een werkbaar project is ontwikkeld en vervolgens witgevoerd. Het gat te ver te veronderstellen dat deze projecten (promoties) er niet waren gekomen zonder het academiseringsnetwerk; toch lijkt het erop dat het HAM deze ontwikkeling nadrukkelijk heeft gefaciliteerd en versneld.

De huisartsen in het academiseringsnetwerk zijn in toenemende mate het venster waardoor de vakgroep naar de huisartsgeneeskundig zorg kan kijken. Het aanreiken van onderzoekbare vraagstellingen zou dan ook een belangrijkere plaats in de inhoudelijke werkplannen moeten gaan innemen.

De verdere uitwerking en uitvoering van een dergelijke vraag kan door de geacademiseerde huisarts zelf geschieden, mar ook een medewerker van de vakgroep huisartsgeneeskunde of een andere universitaire vakgroep zou dit kunnen doen.

Op onderwijggebied heeft het HAM bewezen een belangrijke rol te kunnen vervullen bij de ontwikkeling en uitvoering van nieuwe onderwijsprojecten. Nog nadrukkelijker zou het HAM een andeel kunnen hebben in de ontwikkeling van nieuwe (huisantsgeneeskundige dan wel eerstelins) voorstellen in het kader van het keuze-onderwijs van het basiscurriculum geneeskunde.

Verdere verbetering van de inhoudelijke kwaliteit van de netwerk-huisartsen zal ook de komende jaren aandacht moeten krijgen. De ingeslagen weg met een specifieke opleiding vor geacademiseerde huisartsen op het gebied van methodologie en statistiek van huisantsgeneeskundig onderzoek zal een vervolg krijgen. Nieuwe trainingen op het gebied van diclactiek en ook management (time-management en management van patientenzorg gecombineerd met academische taken) worden ontwikkeld.

Een belangrijk vraagstuk blifft de positie van de patiëntenzorg in de netwerkactiviteïten. Geconcludeerd moet worden dat de academisering van de ziekenhuizen een duidelijk andere richting heeft dan de academisering van de huisartsgeneeskundige zorg. In de academische ziekenhuizen werd aan de ontwikkeling van een hoger niveau patiëntenzorg niet minder aandacht gegeven dan aan werkplaatsfunctie op het gebied 
wan onderwijs en onderzoek. In het Huisartsgeneeskundig Academiseringsnetwerk Maastricht heeft de ontwikkeling van gezondheidszorg slechts een afgeleide betekenis gekregen. De primaire reden hiervan is het financieringsmodel. Doordat het HAM geheel gefinancierd wordt vanuit de structurele middelen wan de universiteit en niet wanuit een Rijksbijdrage van de centrale overheid, ligt het accent vanzelfsprekend op universitair onderwijs en onderzoek en kan verbetering van de zorg slechts een indirect effect zijn als gevolg van de participatie aan onderwijs-en onderzoeksprojecten.

Toekomstige financiering van academische (huisarts)netwerken vanuit de Rijksbijdrage is niet alleen om financieel-economische redenen een noodzaak, maat kan ook inhoudelijke consequenties hebben. Meer rechtstreekse sturing van de huisartsgeneesw kundige zorg, door de introductie van standaanden, nieuwe technologieën, verbeteming van de samenwerking met de tweede lijn en andere innovaties worden daardoor gefaciliteerd, terwijl tevens de kans geboden wordt via evaluatie-onderzoek de mogelijke effecten te meten. Het doel is dan niet alleen meer het wetenschappelijke onderzoek- en onderwijsproject, maar evenzeer de ontwikkeling en innovatie van de zorg. Aangenomen mag worden dat de motivatie van de deelnemende huisartsen sterk zal toenemen als de verbetering van de zorg een expliciet doel van het academiseringsmetwerk kan zijn.

Een eerste poging op dit terrein wordt momenteel in gang gezet door de introduktie van klinische patièntbesprekingen in de academische praktiken. Door de aanwezigheid van studenten, huisartsen in opleiding, academische huisartsen en docenten en onderzoekers van de vakgroep huisartsgeneeskunde mag verwacht worden dat de integratie van onderwijs, onderzoek en patiëntenzorg verder zal worden gestimuleerd. De noodzaak tot deze integratie wordt ook in het discipline-advies geneeskunde 1994 van de Koninklijke Nederlandse Academie van Wetenschappen / Commissie Geneeskunde in haar aanbevelingen en conclusies genoemd.

\section{Centrale coördinatie}

Zowel bij de ontwikkeling en uitwoering van affiliatie-samenwerking als ten behoeve van de noodzakelijke ondersteuning van academiseringsnetwerken is coördinatie van het onderwijs en onderzoek van en met huisattsen belangrijk. De verantwoordelijkheid voor de inhoudelijke toetsing van deze projecten zou bil de valkgroepen huisats geneeskunde kunnen liggen, terwijl de medisch-ethische toetsing viteraard bij de medisch-ethische commissie berust.

De organisatorische verantwoordelijkheid kan gelegd worden bij een centrale en onalhankelijke organisatie in de universiteit. Aangezien ook ziekenhuisafdelingen vaak initiatieven ontplooien, waarbij participatie van huisartsen wenselijk is, is het radzaam ook het academische ziekenhuis te betrekken bij de ontwikkeling van een dergelijk coördinatiepunt. Tenslotte zou ook de regionale huisartsvereniging betrokken moeten worden bij zulk een ontwikkeling.

In een ideaalmodel zou elk project dat bijdragen van huisantsen vraagt bij zo'n coördinatiepunt gemeld moeten worden. Hier worden een antal aspecten, zoals haalbatheid, aanshuiting bij de dagelijkse huisartspraktijk, verwachte belasting voor huisarts (en eventueel patiënt) beoordeeld en wordt tevens andacht besteed aan zaken als algemene informatievoorziening en de honorering van participerende huisarts/dokterassistent(e) en/of patient (reis- en onkostenvergoeding). Indien deze onderdelen als voldoende worden beoordeeld, kunnen in de vakgroep huisartsgeneeskunde de in- 
houdelijke merites van het project besproken en beoordeeld worden. Indien deze stappen zijn genomen kan het coördinatiebureau de onderzoeker/docent behulpzaam zijn bij de werving van de noodzakelijke huisartsparticipatie. Idealiter geschiedt de eerste werving geheel wa het coördinatiebureau. Reden hiervoor is dat de huisarts een waarborg heeft dat wervingen vanuit het coördinatiebureau het hierboven beschrewen beoordelingstraject doorlopen hebben.

Een dergelijke afspraak kan ook met de huisartsen en het bestuur van de DHV (District Huisartsen Vereniging) gemaakt worden.

Vaak blijkt dat de regionale huisartsen ondanks de aanwezigheid van een centraa! meld- en cö̈rdinatiepunt nog steeds rechtstreeks benaderd worden. Aanscherping van de procedure, zonder een trage bureaucratie te worden, lijkt dan zinvol.

Een punt van zorg is het niet-universitaire onderzoek, voornamelijk ontwikkeld door de farmaceutische industrieën. Onderzoeksprojecten vanuit de industrie worden doorgaans rechtstreeks aan de huisartsen aangeboden. De vergoedingen zijn in het algemeen hoger dan die voor universitair onderwijs en onderzoek gegeven kunnen worden. Tevens blijkt dat de gemiddelde looptijd van industrieel onderzoek korter is dan bij universitair onderzoek, hetgeen de participatie-mogelijkheden vergroot. Uit eigen onderzoek komt naar voren dat van de huisartsen die niet deelnemen aan universitair onderzoek, een belangrijk gedeelte niet principieel afwijzend staat tegen medewerking aan onderzoek, hetgeen onder andere blijkt uit deelname aan industrieel onderzoek. Alhoewel industrieën zich uiteraard op een vrije markt bewegen en derhalve huisartsen rechtstreeks kunnen benaderen voor onderzoeksbijdragen, moet men zich afvragen of het niet zinvol zou zijn ook voor dit type onderzoek een kwaliteitsoordeel via de vakgroep huisartsgeneeskunde te introduceren.

Landelijk is woor dit doel in oktober 1992 de stichting METOH (Medisch-Ethische Toetsing Onderzoek Huisartspraktijken) opgericht. Hierin participeren de Landelijke Huisartsen Vereniging (LHV), het Nederlands Huisartsen Genootschap (NHG) en de Koninklijke Nederlandse Maatschappij ter bevordering der Pharmacie (KNMP). De belangrijkste doelstelling betreft het laten verrichten van een beoordeling - waaronder medisch ethische toetsing - van patiëntgebonden onderzoek in de huisartspraktijk. Daamee probeert de stichting METOH duidelijkheid te verschaffen aan de huisartsen of zij te maken hebben met waardevol en verantwoord onderzoek, hergeen van belang is voor de individuele huisarts alsmede voor de aanbieder van het onderzoek, zoals de pharmaceutische industrie.

Het METOH zou een belangrijke bijdrage kunnen gaan leveren teneinde ook het industrieel onderzoek in de huisartspraktijk op methodologische, inhoudelijke en ethische kwaliteit te toetsen, alvorens de daadwerkelijke uitvoering van start gaat. Samenwerking tussen METOH en de vakgroepen huisartsgeneeskunde ligt in de rede.

Een coördinatiebureau zal ook instrumenten moeten aanreiken ter verbetering van de spreiding van de projecten over het aanwezige potentieel aan huisartsen. Nog steeds wordt regelmatig door vakgroepen de gehele regio aangeschreven ten behoeve van nieurwe projecten. Naast het tijds- en kosten-intensieve karakter van een dergelijke grootschalige benadering is het raadzaam de specifieke belangstellingen van de huisartsen te inventariseren en jaarlijks te evalueren. De huisartsen die aangeven niet te willen deelnemen, worden in het jaar na de inventarisatie dan ook niet vamuit het coördinatiebureau benaderd voor participatie aan projecten. Huisartsen met een brede 
belangstelling worden bil alle wervingsacties betrokken, terwijl de huisatsen met zeer" gerichte, thematische belangstellingen alleen voor projecten, vallend binnen her angegeven thema, worden aangeschreven. Wit hier gepresenteerd onderzoek blikt dat de huisarts bij de afweging al dan niet aan projecten deel te nemen, geneigd is de eerder opgegeven voorkeuren in belangrijke mate te volgen.

Fr bestaan nauwelijks sancties voor onderzoekers/docenten van de universiteit of daarbuiten, die van de aangeboden faciliteit van een centraall coördinatiepunt en de wakgroep huisartsgeneeskunde geen gebruik maken. Het rechtstreeks en ongecoördineerd benadenen van huisartsen kan slechts bijgestururd worden, doordat de huisarsen zelf niet ingaan op vagen, die buiten het eerder aangegeven kader vallen. De coördinatic van de benadering en participatie van het huisartsgeneeskundige veld vraagt dan ook van de huisartsen zelf een nadrukkelijke inspanning. Om te komen tot. een verdere professionalisering van de samenwerking tussen huisartsen en de universiteit lijkt verbetering van de inhoudelijke afstemming en coördinatie een noodzaak. Dit houdt dan wel in dat de individuele huisarts wooraf bewust kiest en organiseert, en daarmee de mogelijkheid éen en ander van dag tot dag te bekijken prijsgeeft.

\subsection{Methodologische kanttekeningen}

In het hier gepresenteerde onderzoek is getracht naast theoretische beschrijvingen van samenwerkings- en academiseringsmodellen te komen tot een empirische evaluatie van dit relatief jonge en nog onontgonnen terrein.

De gepresenteerde modellen op het gebied van de werving van affiliatiepraktijken bieden een aanvulling op de voornamelijk internationale literatuur, terwijl de casestudy van het Huisartsgeneeskundig Academiseringsnetwerk Maastricht neuwe inzichten biedt in de landelijke discussie over de academisering van de huisartsgeneeskunde.

Onderbouwing van het proces van samenwerking tussen universiteit en huisarts door bestudering van de literatuur op dit terrein én door het uitvoeten van empirisch onderzoek naar belangrijke variabelen op dit terrein is zinvol en werd tot nu toe slechss sporadisch gedaan. Het algemene belang van de in dit proefschrift gepresenteerde studies is dan ook dat de aandacht voor de noodzakelijke samenwerking tussen universiteit en huisarts nieuwe impulsen krigt. Alhoewel een belangrijk gedeelte van deze sudie zich beperkt tot ến universitaire regio blijkt uit de landelijke enquête en uit de literatuurstudie dat zich vergelijkbare vraagstukken en knelpunten, zowel nationaal als international, voordoen. Het is dan ook annemelijk dat de theoretische en praktische bevindingen en conclusies van dit proefschrift ook in andere vergelijkbare situaties van belang kunnen zijn.

Voor zover kan worden nagegaan in de literatur is een functionerend academiseringsnetwerk (intramuraal dan wel extramuraal) tot nu toe nooil uitgebreid onderwerp wan studie geweest. De beschrijving van het HAM in de vorm van een case-studie draagt dan ook een vrij uniek karakter. De optimalisering van de procedure voor de werving van geinteresseerde huisartsen voor participatie an wetenschappelifk onderzoek (en onderwijs) is echter wel vaker bestudeerd. Op hoofdpunten komen onze bewindingen overeen met andere (internationale) studies, maar op enkele onderdelen zijn nieuwe en geactualiseerde inzichten verkregen. 
Aan de hand van de literatuur en de eigen studies en ervaringen zijn de bestaande. modellen aangepast in een dusdanige vorm dat universitaire onderzoekers op pragmatische wijze de werving van huisartsen modelmatig ter hand kunnen nemen. De gepresenteerde studies en modellen kunnen dan ook gezien worden als een aanvulling op de bestaande theorieën.

Selectiebias kan zijn opgetreden in de twee onderzoeken naar de opvattingen over academisering, aangezien hier de geacademiseerde huisartsen met enige voorkennis gevraagd werden naar hun bevindingen. Tegelijkertijd kan gesteld worden dat dit geen groot probleem was, daar juist een zekere betrokkenheid van belang was voor relevante antwoorden en omdat het hier vaak ging om personen die in thet veld een richtinggevende rol vervullen.

\subsection{Aanbevelingen}

Op grond wan het uitgevoerde onderzoek en de opgedane ervaring worden ten aanzien van de samenwerking tussen universiteit en huisarts de volgende aanbevelingen gedaan:

\section{Aanbevelingen voor de universitaire centra}

1

De benadering van de huisartsen in de universitaire regio zou verder gestandaardiseerd en beter gecoördineerd kunnen worden. De in de literatuur aangereikte modellen zouden in het beleid van de vakgoepen huisartsgeneeskunde op het gebied van de samenwerking met het huisartsgeneeskundig veld een duidelijker plaats moeten krijgen.

2

De belangstelling voor wetenschappelijk onderzoek met behulp van praktizerende huisartsen zal, vanwege de aanwezigheid van alle patiëntencategorieën, in de belangstelling blijven staan. Zowel de vakgroepen huisartsgeneeskunde, de intramurale, klinische vakgroepen als de vakgroepen epidemiologie, sociologie en psychologie hebben de weg naar de huisartsen in het veld gevonden. Om overbelasting voor de huisartsen te voorkomen is het te overwegen een meld- en coördinatiebureau per universitaire regio in te stellen. De opzet van het universitaire onderwijs- of onderzoekproject zou in een vroegtijdig stadium aan dit bureau (toetsing op organisatorische aspecten) en at de vakgroep huisartsgeneeskunde (inhoudelijke toetsing) voorgelegd kunnen worden. De uiteindelijke werving van 'geaccrediteerde' projecten vindt dan plaats via het centrale coördinatiebureat in nauw overleg met de vakgroep huisartsgeneeskunde. Van door het coördinatiebureau bij de huisartsen aangemelde projecten, moet duidelijk zijn dat zij de correcte procedure hebben doorlopen. Indien projecten door afdelingen of vakgroepen rechtstreeks bij de huisarts aangemeld worden, is het risico anwezig dat de gewenste inhoudelijke en organisatorische toetsing niet volgens de afgesproken procedure heeft plaatsgevonden.

3

Coördinatie en organisatie van een academiseringsnetwerk kan verbeterd worden door aanwijzing van een netwerkcoördinator met brede bevoegdheden. Voorwaarde 
Is dat deze functionaris een aanzienlijk gedeelte van zijn/hat tijd aan het netwerk kan besteden.

4

De plaats van projecten op het gebied van de innovatie en kwalleitsbewaking van de gezondheidszorg in academiseringsnetwerken moet verder worden geëxpliciteerd. Het accent ligt thans op onderwijs, onderzoek en registratie. Innovatie en ontwikkeling wan de gezondheidszorg zouden specifieke doelen van het netwerk moeten zinn. Meraan kunnen evaluatiestudies gekoppeld worden.

\section{5}

De financiering van de netwerken blift een zorgpunt. Naast de financiering vanuit de diverse faculteiten der geneeskunde, wordt een gedeelte van de netwerken gefinancierd uit de zogenaamde Tijdelijke Stimuleringsregeling Universitaire Huisartspraktijken (TSUH). Deze regeling is met ingang van 1 januari 1995 komen te vervallen hetgeen betekent dat de jaarlijkse financiering met Fl. 150.000.= afneemt.

Inmiddels heeft het Ministerie van WVS de Ziekenfondsraad gevraagd de verplichtingen in thet kader van deze stimuleringsregeling vanaf die datum over te nemen.

Het ligt echter in de reden te streven naar een financiering die in overeenstemming is met de academische ziekenhuizen (de zogenaamde Rijksbijdrage). Een dergelijke financiering geef niet alleen erkenning van de noodzaak var academisering in de extramurale sector, maar biedt ook de mogelijkheid naast de zogenaamde werkplaatsfunctie van het zorgveld voor de universiteit, aandacht te besteden aan specifieke projecten op het gebied van de directe ontwikkeling van de gezondheidszorg.

6

Aan scholing van de geacademiseerde huisartsen, met name op het gebied van didaktiek, methodologie en statistiek, maar ook op het gebied van praktijkmanagement lijkt. veel behoefte te bestaan. Vanuit academiseringsnetwerken zou hier blijvend aandacht aan gegeven moeten worden.

7

De vakgroepen zouden er nat moeten streven met de farmaceutische industrieèn tot principe-afspraken te komen inzake de benadering van huisartsen voor participatie aan wetenschappelijk onderzoek in de eigen regio. Santenwerking en afstemming net METOH ligt hierbij in de rede.

\section{Aanbevelingen voor de huisarts}

1

Huisartsen wordt aangeraden universilaire medewerkers die hen rechtstreeks benaderen terug te verwijzen naar de vakgroep huisartsgeneeskunde of, indien aanwezig, een centraal coördinatiebureau, alvorens in te gaan op de gestelde vraag. Verder overleg met de DHV en de individuele huisartsen over de meest gewenste benaderingswijze bij wervingsakties voor wetenschappelijk onderwijs en onderzoek is gewenst.

\section{2}

De huisartsen zouden nog nadrukkelijker dan tot nu toe moeten aandringen op voortgaande profilering van de huisartsgeneeskundige discipline, door de ontwiklieling of verdere uitbouw van academische netwerken. Vergelijking met de intramuraal werkende klinische diciplines is hierbij van toepassing. 
Om een gelijkwardige positie te realiseren in de verhouding tussen huisartsgeneeskundig veld en universiteit kunnen de huisartsen bij de vakgroepen aandringen op een bestuurlijke inbreng. Deze inbreng kan varieren van een periodiek overleg wussen de vakgroep en de DHV tot het realiseren van een officiële bestuurszetel in het (dage lijks) bestuur wa de vakgroep huisartsgeneeskunde. Op deze wijze kan mede invulling gegeven worden aan het onderwijs- en onderzoekprogramma en vooral aan de wijze waarop de relatie met de praktizerende huisartsen tot stand komt.

4

Eveneens in het belang van een evenwichtige relatie tussen universiteit en huisartsenveld is het belang een goede balans te vinden tussen de aandacht voor wetenschappelijk onderzoek en onderwijs enerzijds en woor de kwaliteit van de zorg anderzijds.

\section{5}

Aandacht voor time-management is een noodzakelijke voorwaarde om in een toch al drukke huisartspraktijk het academiseringsproces zinvol en aantrekkelijk te doen zijn.

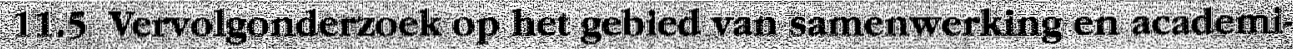

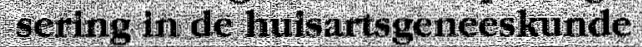

In dit proefschrift werden projecten gepresenteerd ter onderbouwing van de samenwerking met en academisering van praktizerende huisartsen. De volgende projecten zijn daartoe uitgevoerd en afgerond:

\section{Projectnaam}

Het oordeel van huisantsen ower deelname aar wetenschappelijk onderzok

Onderzoek naar management-aspecten in een vakgroep huisartsgeneeskunde

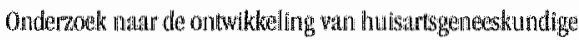

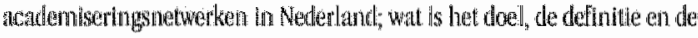

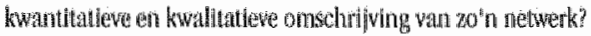

(In samenwerking thet de Begeteidingscommissie Acudenisering

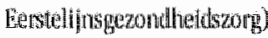

Onderzoelk natar inhoud, proces en uitkonst van de acadenniserêng wan de

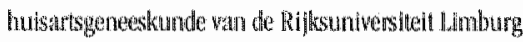

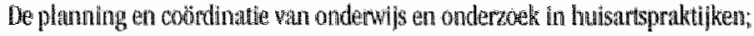

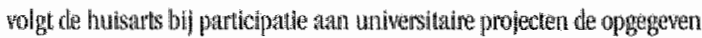
woor hurarsygebeden

\section{Trefwoord}

Samenwerking algemen

Management

Acadenisering

huistantsgenewhunde

Academiseting

buisartsgenteskinde

Samenwerking

management:

(19)
$1991-1993$

Onderzoels-periodle

1989 1991

1992

$1989-1992$

$199 / 3$

Een en ander kan het begin zijn wan een (nationale) onderzoekslijn op dit gebied. Er is reeds vervolgonderzoek gestart op het gebied van 'Management in de huisartspraktijk en de relatie tussen de gezondheidszorgtaak en de academiseringstaak".

Verbetering van het management in de geacademiseerde praktijken zou kunnen leiden tot minder versnippering van taken en toenemende concentratie van de deelnemende huisartsen op cle combinatie van gezondheidszorgtaken en de (academische) 
netwerktaken. Een eerste pilot-studie op dit terrein is inmidels argerond en biedt goede mogelijkheden woor verdere bestudering van dit vraagstuk. Besloten is dan ook een vervolg te geven aan onderzoek op dit terein. Naast onderzoek specifiek gericht op het management, dient in de toekomst bestudeerd te worden welke inhoudelijke implicaties deelname van huisartsen aan een academiseringsnetwerk heeft op het gebied van de uitoefening van de dagelijkse gezondheidszorg. Hier gepresenteerd onderzoek wijst uit dat de huisartsen aangeven dat de newverkdeelname de zorg op enigerlei wijze beinvloedt, maar het is nog onvoldoende bekend wat dat precies betekent. Woorts kan geèvalueerd worden of de geacademiseerde huisartsgeneeskunde wat betreft de ontwikkeling, innovatie en kwaliteitsbevordering van de dagelijkse patièntenzorg daadwerkelijk aan de verwachtingen voldoet. Ook zou er vervolgonderzoek gedaan kunnem worden naar het management van een vakgroep huisartsgeneeskunde, net betrekking tot de samenwerkingsrelaties met het huisartsgeneeskundige veld. In hoeverre is de huidige bestuursvorm en het gekozen management-model ook op den duur geschikt om een structurele relatie met het praktizerende veld te blijven realiseren?

Tenslotte is diepgaand nationaal (en wellicht internationaal) vergelijkend onderzoek narar de bedoelde samenwerkingsrelaties (en academisering) van belang, te meer daar de landelijke overheden reeds vaker hebben aangegeven te willen streven naar landelijke ontwikkeling en coördinatie van huisartsgeneeskundige academiserngsnetwerken. Intermationaal vergelijkend onderzoek op het gebied van de academisering van de huisartsgeneeskunde is bovendien interessant vanuit het perspectief van europese integratieprocessen in de gezondheidszorg. Voorts is dit wan belang voor de uitwisseling van ervaringen en expertise vanuit landen met een goed georganiseerde eerste lijn naar' 'ontwikkelingslanden' op dit terrein. 


\section{LITERATUUR.}

Basisflosofe wan de Riksunversileit Limburg. Maastricht: Rijsuniversiteit Limburg, 1972

Begeleidngscommissie Academisering Eerstelins Geneeskunde. Ontwikkelingsplan academisering huisainsgenewesunde, $\mathrm{BARG} \& 50,1991$

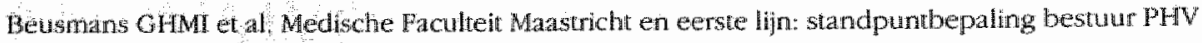

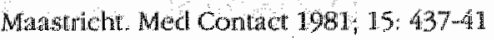

3lanken A, Oudkerk $\mathbb{R H}$. Samen werkt het beter: een onderzoek naar de samenwerking tussen uniyersiteit en hutwatsen. Groningent Fuculeit Bedrifskunde, fijksunvensiteit Groningen, 1988

Blanther A, Metlen Har der. Samenwerking thssen universiteit en eerste lijn bedriffskundig benadero. Med Contact $1987,39 \% 1236: 8$

Booth C. Resestoh and the general practitioner. Br Med.J 1987, 295: 1614-9

Botgiel AEM, Dunn EV, Lamont CT, at al. Recruiting family physicians as participants in reseatch. Ham Pract $1989: 6: 1,68-72$

Bolter CH. Industrie en orgenisatie; een verkenningstocht. Khuwer/NWE, 1970

Brouwer W, Romme MAJ. Palculteit en extewijh. Utrecht: Bohn, Soheitema \& Holkema, 1981

Brouwe: W. Academisering in de eerste lijn een noodzak. Med Contact, 1982; 11:321-2

Brueren MM, Dinant GJ, Schouten BJ, Ree JW wat Hypenensiediagnostek door de huisarts: de WHG-\$andart getoetst an de ambulante bloxddrukmeting. Ned Tijd roor de Gen 1995; 13969: 278-82

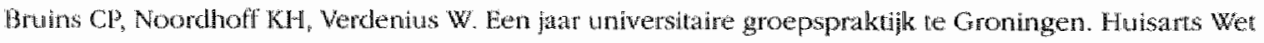
$1970 ; 13: 281.6$

Colnen DI, Breslat D, Porter DK, et al. The cost implications of acalemic group practice. The new england journal of medicine $1986 ; 24: 1553 \%$ ?

Crebolder HFJM, Kocken RI. Academisering van huisartspraktijken. The Practioner (Ned witgawe) 1989; 15 : $1130-2$

Crebolder HFIM, Te leen in de eerste hin; inaugurale rede, Madtrich: Faculteir der Geneeskunde, Rijksuniversilleut Limburg, 1987

Deen $\mathrm{KJ}$ w. Edinburgh University Practice Teaching Unit. Fuisarts we $1961 ; 4: 78-9$ 
Duederiks JPM, Stevens FCJ. Ervaringen met het Academisch Ziekentuis Maastrich: Een onderzok natar do beeldwoming van cen ziekenluis. Maastricht 1991

Dipsterhuis P. Academisering/affiliatie. Groningen: Vakgroep buisartsgeneeskunde Riksuniversite Groningen, 1984

Douma $S_{n}$ Schreuder $H$. Economic approaches to organizations. Prentice Hall International Ld. Unired Kingdom; 1992

Euk JThM wam, Gubbells JW. Wetenschappelijk onderzoek in de huisartsgeneeskunde. 2e drak. Lelystad; Meditekst, 1987

Es JC van. Faculteit en eerste lijn, voorstel over de wijze waarop de medische faculteit kan worden betrokken bij de extramurale gezondheidszorg. Med Contact 1981; 7: 179 82

Es JC van. Patient en huisarts; Een leerboek huisartsgeneeskunde. Oosthoek, Scheltema \& Holkema.Urrech, 1980

Fijten GH. Rectal bleeding, a danger signal? Proefschrift. Maastricht: Rijksuniversiteit Limburg, 1993

Gagnon FA, Susak LE, Goulet FE. Getting started in family research (part 2). Can Family Physician 1991; 37: 850-4

Gagnon FA, Susak LE, Goulet FE. Getting started in family research (part 1). Can Family Physician 1991; 37: $596-601$

Gils MR van. De organisatie van organisaties. M\&O Tijdschrift voor organisatiekunde en sociaal beleid 1978; 32: $9-31$

Godfroij A. Netwerken van organisaties; Strategleën, spelen, structuren. VuGA-uitgeverij. Den Haag, 1981

Govaent ThME. Influenza bij ouderen. Proefschrift. Maastricht: Rijksuniwersiteit Limburg, 1994

Gowaen ThME, Dinant GJ, Aretz K, Masurel N, Sprenger MIW, Knotmenus JA. Adverse reactions to influenza vaccine in elderly people: randomised double blind placebo controlled trial. Br Med J 1993; 307; $988-90$

Grol R, Beunden W van, Binkhorst T, Toemen T. Patient education in Family Practice: the Consensiss Reached by Patients, Doctors and Experts. Farm Pract 1991; 2: 133-9

Groot TLCM. Management van universiteiten; een onderzoek naar de mogelijkheden voor doelmatig en doeltreffend universitair bestuur. Wolters-Noordhoff. Groningen, 1988

Groot A des, Knotmerus JA Academisering van de eerste lijn of vermaatschappelijking wan de academie? Med Contact 1982; $2: 37-9$.

Hendrikse GWy. Coördineren en motivenen, een overzicht van de economische organisatietheorie. Acadiemic service, economie en bedrifskunde. Schoonhoven, 1993

Herber CP. Why family practice research? Can Family Physician 1991; 37: 335-8 
Huygen F) Jenkins CD, Kok H], Pedersen PA. Report of the evaluation committee on he INNOWATIOW FUWD for EXTRAMURAL ACTVITISS of the Faculy of Medicine / Universiry Limburg, Maastricht, 1990

Integral plan woor universiave participue in de regionale gezondheidszorg. Mastrich: Rijksunversiteit Limburg, 1982

Jacobs 13 M. Coordinaticbureat Eerte Lim; werketijkheid of illusie? Doctoraalscripte 1988

Jansen WM, Tan LHC, Vlewten CPM wan der, Grol RPTM. Assessing technical chinical skills of general practioners in the Netmerlands: Results of a pilot project labstact. In: Book of abstacts WOMCA/SIMG congress 1993, Quality of cane in family medicine/general practice, jun 13-17 199 , The Hague. Urecht: NHG, 1993. 388.

Jansen JM, Tan LHC, Vleuten CPM wan der, Grol RPTM. Toesing wan medisch-nechnische vardigheden bij huisartsen: een vergelijking van dric verschillende methodes. Im: Metz JCM, Scherpbier AJA, Houkoop E Ged). Gemond Onderwijs 2, NVMO, Nimegen, 1993: 15963

Keuning D, Eppink DJ. Management en organisatie: Theorie en toepassing. H. E. Stentert Kroese BV. Leiden/Antorerpen, 1985

Khotherus JA, Wolfs GGMC, Muyers PEM. Bengne prostathyperplasie: een probleem voor parient en huisants. Huisants Wer 1989; $32(11): 420-7$

Knothens JA. Dalectek van het onderzoek in de huisantsgeneesknde; inaugurale rede, Maastrich: Faculteit der Geneeskunde, Rijksuniversiteit Limburg, 1988

Knotmens JA, Volovics A. Medische statistiek en onderzoek in de huisartsgeneeskunde. Nederlands Huisartsen Genootschap. Utrecht, 1900

Knotmerus JA, Vet HCW de. Effectiviteitsonderzoek in de huisartspraktilk. Huisarts Wet 1987; 30:49,50-3,72$5.116 \mathrm{~m}$

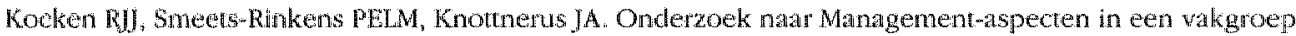

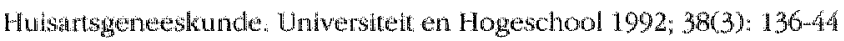

Kocken RI, Meijer.JS, Ooms FEM, Smeets-Rinkens PELM. Academisering van de Huisartsgeneeskunde, Onderoek nat de ontwikeling van huisartsgeneeskindige acudemiseringsnetwerken in Nederland; wat is

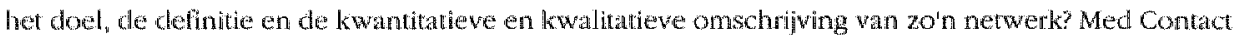
$1992(47): 26: 811-4$

Kocken RJ, Prenger-Duchateau A, Smeatswinkens PELM, Knotnenus JA General Practitioners as participants in scientific research; letter to the editor Br J Gen Pract 1993; 43:305-6

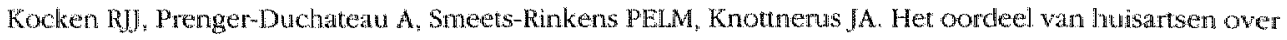
deelname aary wetenschappelijk onderzoek. Huisarts Wet; 1992(1):32-4

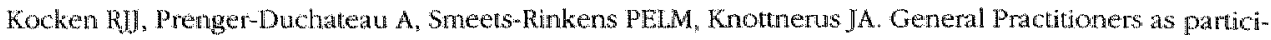
pants un scientific rescarch - What do they think of ito wewsletter WHO -2000 Health for all $1992 ; 18: 2-4$ 


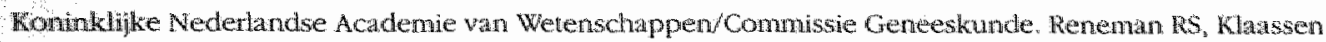
ABM(Red). Discipline-advies geneeskunde 1994. Amsterdam: KNAW, 1994

Konwem E tnerorganisatonele samenwerking in het licht wan rubheorie en coaluetheorie. Im: Greve wh die; wrakking Wy (red.). Strategie van Samenwerking tussen organisaties in welzins en gezondheidswark. Wochem-Poperinge: De hijstroon, 1980

Krogt ThW $\mathrm{M}$ wan der, Vroom CW. Organisatie in beweging. Lemma bv. Utrecht, 1991

Langenberg $M$, Hellemons-Boode BSP, Hee JW van, Vermeer F, Lodden $\mathrm{X}$, Knotherus JA. Prevalence and ristkprofile of atrial fibrillation in general practice labstract. In: Book of abstracts WONCA/SIO Congress 1993 . Quality of care in family medicine/general practice, jun 13-17 1993, The Hague. Utrech: NHG, 1993: 321

Ledecq RMFM, Crebolder HFIM, Breevoor ELMG. Wens en werkehijheid in achdemische huisartspaktijken; discrepanties. Med Contact 1994(49); $41: 1278-80$

Leen wen YD wa, Pollemans MC, Dusman H, Vleuten CPM wan der, Grol RPTM. De huisartsgeneeskundige Kennistoets construckaliditeit en betrow waarheid. Elke maten meten wat? lin: Metz JCM, 5 cherploter AllA. Houtkoop $\mathrm{E}$ (red) Gezond Onderwils 2, NVMO, Nimegen 1993: 164-8

Leeuwen YD van, Eekhof JAH, Pollemans MC, Kramer AWM Mol SSL. The knowledge test for genetil prictice in the Nedherlands: A consulation hour on paper [abstract]. In: Book of abstracts WONCASSMG congress 1993. Quality of care in fanilly medicine/general practice, jum 13-17 1993, The Hague. Utrech: NHC, 1993: 307

Martens FMJG, Opt Root JMH. Practical Medical Education in General Practice. Med Education $1992,26: 213-7$

Meijer 15 , Schade E. Van gastdocent tot UHP-ants: de ontwikkeling van de academisering wan de huisarts geneeskunde. Huisarts Wet 1992; $35: 29-31$

Melker RA de. Wat wringt er in de eersteliphs gezondheidszorg: Med Contact $1982 ; 25: 731-4$

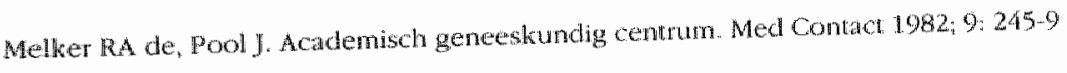

Memorie van antwoord bil het ontwerp van wet van 3. december 1975 , stb. 717 (Wet Riksuniwersiteit Limburgh

Metsemakers fFM. Unlocking patiens records in general practice for researdh, medical education and quality assurance: the Registration Network Family Practices. Proefschrift. Maastricht: Rijksuniwersiteit Limburg, 1994

Metsemakers IFM, Hoppener P, Knotmens JA. Kocken RU, Lmonard CBG. Computerized health information in the Netherlands: a regusuation network of family practices. Brit I Gen Pract 1992: 42: 102-6.

Metsemakers JFM. Crebolder HFJ at. Het adoptiemodel als een vorm van praktsch medisch onderwijs. Gezond Onderwis I. Bohn, Stahlu van Loghum, Houten/Zeventen, 1992

Mulder JD. Academische warkplaats eerstelins gezondheidszorg. Med Contact 1982: 26:761-3

Mintaberg H. Organisatiestucuren. Prentice Hall-Academic Service. Schoonhoven, 1994 
Muris JWM, Starmans R. Non acute abdominal complaints. Diagnostic studies in general practice and outpa uknt clinic. Proefschrift. Maastricht: Rijksurviversiteil Limburg, 1993

Murphy E; Splegal N, Kinmonth AL. "Will you help me with my research?" Gaining access to primary care sertings and subjects. Prit J Gen Pract 1992; $42: 162-5$

"Nationale Studie naar ziekten en verrichtingen in de huisartspsaktipk" van het Nederlands instituut woor onderzock wan de eerstelijn gezondheidszorg (NTVEL, mej, 1990)

Nieuwbouw academisch ziekenhuis Maastricht: beloften, belang en noodzaak. Academisch Ziekenhuis Mastricht. Mastricht, 1983

NHG-standaarden woor de huisarts, Rutten GEHM, Thomas S (red). Bunge. Utrecht, 1993

Nota Academisering in de Eerstelijn. Maastricht: Faculteit der Geneeskunde, Rijksuniversiteit Limburg, 1982

Op weg natar Ale AWEG, Rapport van de adviesgroep academisering wan het Interfacultair Overleg. Huisartsgeneeskunde, 1984 .

Partners op weg natr een zakelijke toekomst, Rapport van de VVAA/RL ten behoeve van het Ministerie van WWC, 1992

Portegijs PIM, Kraan HF, Knottnerus JA, Stoffers HEJH. Wat heet somatisalie? 1. Een zoektocht uit de internationale literatuur naar een definitie voor huisartsgeneeskundig onderzoek. Huisants Wet $1992 ; 35 ; 18-25,43$

Portegijs PJM, Kraan HIF, Knotnerus JA, Stoffers HEIH. Wat heet somatisatie? 2. Een antwoord uit de internationale literatuur getoetst aan 19 jaar Huigarts en Wetenschap. Huisarts Wet 1992; 35: 65-9

Projectgroep Evaluatie TSR. Academisering in een netwerk. Tussentijclse rapportage van de projectgroep Evaluatie van de Tijdelijke Stimule ringsregeling Universitaire Huisartspraktijken. Ansterdam: Institulat voor Hulsartsgenecskunde, Universiteit wan Amsterdam, 1990

Projectgroep Evaluate TSR. Academisering in de huisartspraktijk. Tussentijdse rappontage van de projectgroep Evaluatie van de Tijdelijke Stimuleringsregeling Universitaire Huisartspraktijken. Amsterdam: Instituut woor Huisurtsigeneeskunde, Universiteit van Amsterdam, 1990

Projectgroep Evaluatie TSR. Academisering in zicht. Tussentijdse mpportage van de projectgroep Evaluatie van de Tijdelijke Stimuleringsregeling Universitaine Huisartspraktijken. Arnsterdam: Instituut voor Huisartsgeneeskitunde, Universiteit wan Amsterdam, 1990

Projectgroep Evaluatie TSR. Academisering in de praktijk. Tussentijdse rapportage van de projectgroep Fvaluatie van de Tijdelike Stimuleringsregeling Universitaire Huisartspraktijken. Amsterdam: Instituut voor Huisartsgeneeskunde, Universiteit van Amsterdam, 1990

Projectorganisatie Academische ziekenhuizen: Eindrapport deel A: Advies inzake de uitvoering van het convenant academische ziekenhuizen. 's Gravenhage, 1987 
Fopectorganisatie Academische ziekenhuizen: Eindrapport deel B: Advies inzake de beleidsnotie "Nadere reyseling van de verantwoordelijkeid voor acadenische zlekenhuizen". 's Gravenhage, 1987

Rupon wan de subcommissie gezondheids(zorg)wetenschappen, Koninklije Nededandse Acallemie van Wetersoliapen, 1991

happort van de Commissie Academisering Eerstelijnsgezondheidszorg en Ambulante Geestijke Gezondheidszorg in Limburg. Maastricht: Rilksuniversiteit Limburg, 1983

Ree $\mathrm{W}$ wan, Pol G van aler. Efficacy and tollerability of very low and medium dose felodipine in older patients with mild to moderate hypertension [submitted]

Registratienet Huisartspraktuken; gezondheidsproblemen en diagroses in de huisartspraktipk: (Rijksuniversite it. Limburg, jaargang 5, nummer 1, maar 1993)

Fudnick $\mathrm{KV}_{\text {, }}$ alter MD, Spitzer $\mathrm{O}$, Pierce $\mathrm{J}$. Comparison of a private family practice and a university teaching pructice. Journal of medical education 1976; $51: 395-402$

Scapens $\mathbb{R W}$. Management Accounting: A review of recent developments. McMillan Education Ltal. Unitud Kingdom, 1987

Schieman CI. Beheersing van bedriftsprocessen. H. E. Stenlen Kroese. Leiden, 1975

Schonck RSM, Beusmans GMHI, Crebolder HFJM, Innowation in homecare for the alderly labstract]. Tru: Book of abstracts WONCA/SIMG congress 1993 , Quality of cane in family medicine/general practice, jun 13-17 1993, The Hague. Ltrecht: NHG, 1993: 6

Schondk RSM, Beusmans GMHI, Grol R, Mellink R, Grebolder HFMM. Een aonsensusmethode voor multidiscuplinaine richtijnontwikkeling in de thuiszorg. Kwaliteir \& Zorg 1993, 1: 135-47

Silagy CA, Carson NE. Factors inflecting the level of interest and acliwity in primary care research among. general practutioners. Fam Pract $1989 ; 6: 173-6$

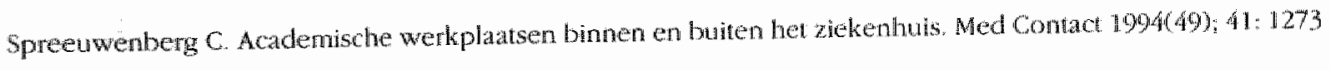

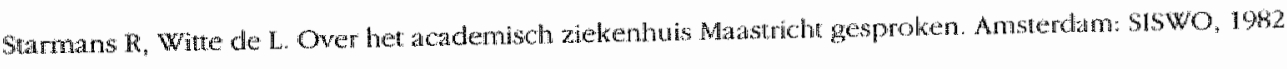

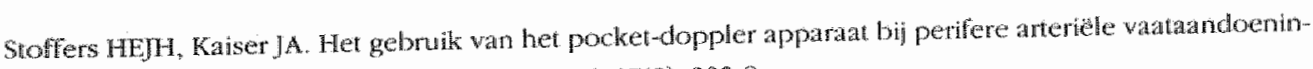
gen: een literatuuronderzot: Huisarts wet $1994 ; 37(8): 333-8$

Stofters HEJH, Kaiser V, Knotherus JA. Prevalence in general practice. In: Fowkes FGR. Fpidemiology of peripheral vascular disease. London: Springer Verlag, 1991: 109-15

Stoffers HEIH, Kaiser $\mathrm{V}$. De uitwoering van pat tentgebonden andoeningsgericht wetensehappelifk onder

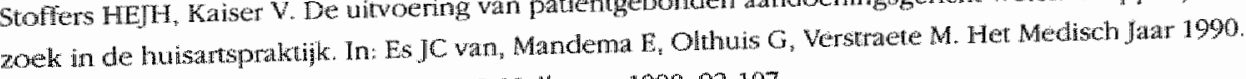
Utrecht/Antwrerpen: Bohn, Scheltema \& Holkema, 1990: 92-107

Stoffers HEJH, Kaiser $\mathrm{V}$, Kester A, Schowten H, Knotmerus JA. Peripheral Anterial Occlusive disedse in Gerent Practice the reproducibility of the Ankle-Arm systolic pressure ratio. Scan I Prim Health Care 1991; 9: 109-14: 
Vierhout WPM. Het gezamenlijk consult van thuisarts en specialist in de eerste lijn. Proef schrift. Madistrich: Rijksuniversiteit Limburg, 1994

Whassenberg A. Netwerken: organisatie en strategie. Boom Meppel. Amsterdam, 1980

Weel van $C$. Alledaagse ziekten en een gezond verstand. Inauguralle rede Nijmegen: Katholieke Universiteit Nijimegen, 1986

Weick KE. Educational organizations as loosely coupled systems. Administrative Science Quarterly 1976: 1-19

Weijden GDEM van der, Futten JBF, Brandenburg BJ, Grol RPTM, Velden K van der. Cholesterol diagnosis and treatment in Dutch general practice A comparison with national guidelines. In: Velden J wan der Bill $D_{w}$ Brandenburg B, Hofstra M, Grol R. NHG-standaarden en kwaliteit van zorg in de huisartspraktijk. Eind-rapport, Ulrecht: NHG, WOK, NIVEL.

Weigden GDEM wan der, Grol RPTM, Knotnerus JA. Optimal evaluation of national cholesterol guidelines in general prattice labstractl. In: Book of abstracts WONCA/SIMG congress 1993, Quality of care in family medicinefgeneral ptactice, jun 13-17 1993, 'The Hague. Utrecht: NHG, 1993: 155

Williamson OE. Markets and hierarchies: analysis and antitrust implications. Free Press. New York, 1975

Williamson OE. The economics of organization: the transaction cost approach. American Joumal of Sociology 1981; $548-577$

Wolls GGMC, Knotunerus JA, Janknegt RA. Prevalence and detection of micturition problems among elderly males: a population study in 2734 men. J Urol 1994; 152: 1467-70

Zwatan Alt van der Netwerken: samenhang en samenwerking in de gezondheidszorg. In: Maarse JAM, MurVeeman IM (red). Beieid en beheer in de gezondheidszorg; Problemen, structuren, processen en effecten. van Gorcum. Assen, 1990: 411-425 


\section{SAMENVATTING}

Elke klinische, universitaire vakgroep staat voor de taak een verbinding te realiseren tussen de vakgroep en het veld van praktizerende huisartsen, zowel voor de taken op het gebied van onderwijs, huisartsopleiding en wetenschappelijk onderzoek als voor de innovatie en de kwaliteitsbewaking van de patiëntenzorg. Dat geldt uiteraard ook woor de vakgroep Huisartsgeneeskunde van de Rijksuniversiteit Limburg. Het tot stand brengen van een samenwerking tussen deze vakgroep en de huisartsen in de universitaire regio heeft veel inspanning gekost, niet alleen vanuit de universiteit, maar vooral van de praktiserende huisartsen. Om deze samenwerking te ontwikkelen moesten diverse barrières overwonnen worden. Financieringsproblematiek, onvoldoende afstemming en coördinatie en de overbrugging van een geografische kloof zịn hiervan slechts voorbeelden.

De samenwerking vindt plaats op twee manieren, te weten academisering en affiliatie. 'Academisering' betekent dan de gestructureerde/geïnstitutionaliseercle samenwerking tussen universiteit en huisartspraktijken, waarbinnen onderling samenhangende en vooraf overeengekomen activiteiten plaatsvinden ten behoeve van (de integratie van) werenschappelijk onderwijs en onderzoek en patiëntenzorg.

De voor deze samenwerking noodzakelijke infrastructuur wordt vervolgens het 'academiseringsnetwerk' genoemd.

'Affiliatie' wijkt inhoudelijk niet erg af van academisering, aangezien ook bij affliatie de inhoudelijke nadruk ligt op de integratie van onderwijs of onderzoek met de patiëntenzorg. Toch is er een duidelijk verschil in omvang, intensiteit en continuiteit van de samenwerking tussen de universiteit en de geaffilieerde huisarts(praktijk).

De gemaakte afspraken gelden doorgaans voor één specifiek onderwijs- of onderzoeksproject en gelden slechts voor de duur van dat project (variërend van 1 tot 3 jaar).

Dit proefschrift beschrijt het proces van de samenwerking en de academisering op het gebied van de huisartsgeneeskunde, zoals zich dat aan de Rijksuniversiteit Limburg heeft voltrokken. Startpunt is de oprichting van de Rijksuniversiteit Limburg, neer in het bijzonder de Faculteit der Geneeskunde en de dissertatie eindigt met de beschrijving van het academiseringsnetwerk huisartsgeneeskunde anno 1994.

Het proefschrift is als volgt opgebouwd.

Na de inleiding (hoofdstuk 1), wordt in hoofdstuk 2 uitvoerig stilgestaan bij de nationale en internationale literatuur op het gebied van samenwerking in en academisering van de huisartsgeneeskunde. Ook wordt aandacht besteed aan de voor de Rijksuniversiteit Limburg specifieke literatuur op dit terrein. Er blijkt relatief weinig literatuur beschikbaar te zijn over samenwerkings- en academiseringsconcepten op het gebied van onderwijs en onderzoek in de huisartsgeneeskunde. Nationaal wordt in een aantal inauguraties aandacht besteed aan de noodzaak tot participatie van individuele huisartsen aan universitaire onderwijs- en onderzoekprojecten. Het symposium "Faculteit en Eerste Lijn" in 1980 geeft een belangrijke conceptuele en prakrische aanzet tot de constructie van academische werkplaatsen. Het concept van de AWEG (Academische Werkplaats Eerstelijns Gezondheidszorg) wordt vervolgens in de jaren 80-85 verder uitgewerkt. Pas in 1987 wordt het academiseringsproces ook vanuit de 
bedrijfskundige invalshoek bestudeerd en beschreven. Hierna volgt een periode waarin, gefaciliteerd door het Ministerie van Welzijn, Volksgezondheid en Cultuur (WVC) de (projectgroep van de) Begeleidingscommissie Academisering Eerstelijnsgezondheidszorg (BAEG) belangrijke bijdragen levert aan de verdere ontwikkeling van de idee-vorming over academisering in de huisartsgeneeskunde.

In de internationale literatuur worden hoofdzakelijk suggesties gedaan op het gebied van de affiliatie-samenwerking, met name voor de uitvoering van wetenschappelijk onderzoek in de huisartsgeneeskunde. Slechts in zeer beperkte mate worden initiatieven beschreven, vergelijkbaar met wat in Nederland 'academisering' of 'academische werkplaatsen' genoemd kan worden.

Hoofdstuk 3 gaat dieper in op de beschrijving van het Huisartsgeneeskundig Aacademiseringsnetwerk Maastricht (HAM), zoals dat aan de Rijksuniversiteit Limburg is ontwikkeld. In de vorm van een case-study wordt de werving en contractering van huisartspraktijken geanalyseerd, alsmede de inhoud en de financiering van het totale netwerk.

Het ontwikkelen van academisering in de huisartsgeneeskunde volgens de netwerkconcepten wordt reeds langere tijd gezien als het meest in aanmerking komende model. Dit blijkt onder andere uit de diverse rapportages van de Begeleidingscommissie Academisering Eerstelijns Gezondheidszorg.

De hoofdstukken 4 en. 5 geven modelbeschrijvingen van respectievelijk de benadering van en de samenwerking met affiliatie-praktijken en de academisering van de huisartsgeneeskunde.

De modelbeschrijvingen zijn tot stand gekomen op basis van de literatuur-studie en de opgedane ervaringen. Retrospectieve beschouwing van het Maastrichtse academiseringsmodel aan de hand van de bedrijfseconomische en bedrijfsorganisatorische literatuur levert een vijftal relevante theorieën op. Deze theorieën geven elk op hun eigen wijze inzicht in het proces van de academisering van de huisartsgeneeskunde en worden dan ook besproken. Ook de relatie tussen de besproken literatuur en de bedrifseconomische theorieern enerzijds en het HAM anderzijds wordt aangegeven.

In de modlelbeschrijving voor de benadering van en de samenwerking met affiliatiepraktijken worden vijf fasen onderscheiden, te weten voorbereiding, acceptatie, werving, uitvoering en nazorg.

De projectgroep Evaluatie van de Begeleidingscommissie Academisering Eerstelijns Gezondheidszorg (BAEG) voerde een nationale studie uit naar de ontwikkeling van huisartsgeneeskundige academiseringsnetwerken in Nederland. Deze studie wordt in hoofdstuk 6 weergegeven, waarbij het doel, de definitie en de kwalitatieve en kwantitative omschrijving van een academiseringsnetwerk centraal staat.

Hoofdstuk 7 gat dieper in op de ontwikkeling van het academiseringsnetwerk van de Rijksuniversiteit Limburg en kijkt naar zowel de inhoud als het proces en de uitkomst.

Een evaluatie-studie middels een schriftelijke enquête onder 29 vaste stafleden van de vakgroep huisartsgeneeskunde en 55 geacademiseerde huisartsen wordt beschreven. Onderzocht werden aspecten van academisering, zoals doelstelling en definitie, optimale omvang van het netwerk en contract-technische relatie tussen de beide partijen, 
selectie van praktijken, kwaliteitstoetsing, de mogelijke aanpassing van het praktik- management en de invloed van deelname aan het academiseringsnetwerk op de uitoefening van de patiëntenzorg. De resultaten wijzen erop dat academisering niet alleen van belang is om huisartsen op structurele basis te betrekken bij het universitalre onderwijs en onderzoek, maar ook voordelen voor de huisartsen zelf oplevert. De geacademiseerde huisarts is van oordeel zijn vak beter te kunnen uitoefenen en door de deelname aan het academiseringsnetwerk met nieuwe elementen in aanraking te komen. Deelname aan academisering vergt aanpassingen, maar de voordelen voor de huisarts lijken op te wegen tegen de (geringe) nadelige effecten, zoals de noodzaak tot aanpassing van het praktijkmanagement.

Hoofdstuk 8 beschrijft de algemene aspecten van de samenwerking tussen de wakgroep Huisartsgeneeskunde van de Rijksuniversiteit Limburg en de praktiserende huisartsen in de universitaire regio. Welke variabelen zijn voor de deelnemende en niet-deelnemende huisartsen belangrijk in hun afweging om wel of niet aan wetenschappelijk onderzoek van de universiteit deel te nemen? Door middel van een enquête onder twee representatieve steekproeven van huisartsen die regelmatig of incidenteel deelnemen aan onderzoek vanuit de Rijksuniversiteit Limburg, en huisartsen die daaraan niet deelnemen, werd nagegaan welke criteria daarbij worden gehanteerd, welke problemen worden ondervonden, welke informatie door de huisarts vooraf en na afronding van het onderzoek wordt gewenst, en in hoeverre het dagelijks handelen van de huisarts door participatie aan wetenschappelijk onderzoek wordt beïnvoed. De bereidheid tot deelname aan onderzoek is in het algemeen groot. De belangstelling voor het gekozen onderwerp en de belasting voor patiënt en huisarts zin de belangrijkste factoren bij de afweging om wel of nier deel te nemen. Een goede terugrapportage wordt op prijs gesteld en een niet onaanzienlijk deel van de huisartsen acht het van belang op enigerlei wijze genoemd te worden als deelnemer. Ongeveer de helft van de responderende huisartsen vindt het redelijk een vergoeding voor extra bestede tijd te ontvangen.

Adequate planning en afstemming is bij elke samenwerkingsvorm wan evident belang. Dat is ook het geval bij de samenwerking tussen de universiteit en de huisarts. Maar laten de huisartsen zich "plannen" ? Hoofdstuk 9 probeert een antwoord te geven op deze vraag. Onderzocht werd in hoeverre huisartsen bij participatie aan universitaire projecten de eigen voorkeursgebieden volgen. De resultaten geven aan, dat er een verband bestaat tussen door huisartsen uitgesproken voorkeuren en de uiteindelijke participatie aan universitaire projecten. Zelfs zonder directe sturing in de vorm van een gestratificeerde benaderingsstrategie is het verband tussen de voor-en de nameting in het algemeen duidelijk. Dat het verband bij de onderwijsprojecten groter is dan bij de onderzoeksprojecten was te verwachten.

Het verband is over de thele linie echter zodanig dat aangenomen mag worden dat huisartsen vooral op basis van inhoudelijke voorkeuren aan specifieke projecten gaan deelnemen. Het wordt aanbevolen de toekomstige benaderingsstrategie meer af te stemmen op de door de huisartsen uitgesproken voorkeuren. Het gerichter benaderen en werven van huisartsen voor universitaire projecten kan voordelen heblben voor zowel de universiteit als de huisarts. Voor de universiteit werkt een dergelijke benadering waarschijnlijk kosten-effectiever, aangezien momenteel (zelfs voor kleinere projecten) vaak de gehele regio benaderd wordt. voor de huisarts is het een voordeel dat 
er geen benaderingspoging wordt ondernomen indien vooraf is a angegeven dat voor het specifeke onderwerp geen belangstelling bestaat. Het aantal onnodige benaderingen van de praktijk neemt daardoor aanzienlijk af.

Hoofdstuk 10 geeft inzicht in een aantal management-aspecten van de vakgroep. Een goed management van de vakgroep is een voorwaarde te komen tot een optimale samenwerking met de huisartsen in de regio. De medewerkers van de vakgroep huisartsgeneeskunde werken graag bij deze organisatie en zijn goed te spreken over hun werk Er bestaat een sterke behoefte om goede resultaten te behalen en men meent in de regel een maximale inspanning te leveren om de beoogde resultaten te behalen. Ook het hexibele beleid inzake de werktijden wordt als zeer belangrijk en positief ervaren. De functie-eisen zijn voldoende duidelijk en de medewerkers hebben woldoende bevoegdheden om hun werk goed te cloen. De inclividuele medewerker voelt en krijgt voldoende verantwoordelijkheid binnen het eigen taakgebied. Begeleiding en controlle worden redelijk positief ervaren. Punt van zorg is het onderwerp besluitvormingsprocessen" en "overlegstructuren". Het nemen van besluiten vraagt naar het oordeel van de respondenten veel tijd, terwijl tegelijkertijd geconstateerd wordt dat de kwaliteit van die besluiten niet beter is.

Naarmate medewerkers langer bij de vakgroep werken stellen zij hogere eisen aan de aspecten planning, informatievoorziening, begeleiding en motivatie en inspiratie op cle werkplek. Narmate men een hogere werktijdfactor heeft $(>0,5$ Fte anstelling bij cie vakgroep) wordt negatiever gedacht over de onderwerpen besluitwaardigheid en informatievoorziening. Er blijken verschillen te zijn in perceptie en beleving van bet management tussen het wetenschappelijk en het ondersteunend personeel. Met name het niet-wetenschappelijk personeel is van mening dat middelmatigheid redelijk geaccepteerd is en dat er in het allgemeen te veel tijd wordt besteed aan vergaderingen en. overleg. Voorts blijkt dat deze personeelscategorie in mindere mate verantwoordelik heid krijgt toebedeeld voor de eigen werkzaamheden en minder wordt gestimuleerd om risico's te nemen. Er wordt door beide categorieën in lichte mate een statusverschil ervaren tussen het wetenschappelijk en het ondersteunend personeel.

Hoofdstuk 11 tenslotte geeft een algemene beschouwing. De samenwerking tussen universiteiten en praktizerende huisartsen wordt hier beschouwend besproken. Naxst een witwerking van de begrippen "academisering' en 'affiliatie' worden de resultaten van de empirische studies afgezet tegen de realiteit van het Huisartsgeneeskundig: Academiseringsnetwerk Maastricht. Voorts worden er aanbevelingen gedaan, zowel voor universitatie centra als voor de praktizerende huisartsen. Ook worden er suggesties voor vervolgonderzoek gedasn en wordt stilgestaan bij de methodologische beperkingen van het beschreven onderzoek. 


\section{SUMMARY}

Every clinical university department of general practice is faced with the task of creating a link between itself and GPS in the field, both as regards its duties in the area of teaching, training GPs and scientific research and where innovation and quality control in patient care are concerned. This naturally also applies to the Department of General Practice at the University of Limburg. Ensuring collaboration between this department and the GPs in the area covered by the University has taken a lot of effort, not only on the part of the University but above all on that of the GPs themselves. In order to bring about this collaboration it was necessary to surmount a variety of obstacles. Problems associated with financing, lack of rapport and coordination and the task of bridging the geographical gap are just a few examples.

Collaboration takes two forms, namely academization and affiliation. "Academization" refers to structured/institutionalized collaboration between the university and general practices, with coordinared activities (agreed on in advance) taking place in order to facilitate integration between scientific teaching and research on the one hand and patient care on the other.

The necessary infrastructure for such collaboration is referred to as the "academization network".

"Affiliation" does not differ significantly from academization as far as actual content is concerned, given that its emphasis is also on integrating teaching or research with patient care. There is nevertheless a clear difference in the extent, intensity and continuity of the collaboration between the university and the affiliated GP or practice.

The agreements made generally apply to a single specific teaching or research project and are valid only for the duration of that project (ranging from 1 to 3 years).

This dissertation describes the process of collaboration and academization in the area of general practice as it has been implemented at the University of Limburg. It starts with the foundation of the University, specifically the Faculty of Medicine, and concludes with a description of the academization network for general practice as it existed in 1994.

The structure of the dissertation is as follows:

After the introduction (chapter 1), chapter 2 deals in detail with the national and international literature on the topic of collaboration and academization in the area of general practice. It also considers the literature dealing specifically with the University of Limburg. Relatively few publications turn out to be available on the concepts of collaboration and academization in teaching and research in general practice. Where the Netherlands is concerned, a number of inaugural lectures deal with the need for individual GPs to participate in university teaching and research projects. The $1980 \mathrm{sym}-$ 
posium "Faculty and Primary Care" gave an important conceptual and practical impetus to the construction of academic "workplaces". The concept of the "Academic Workplace in Primary Care" (AWEG) was then developed during the period 1980-1985. It was only in 1987 that the process of academization was also studied and described from the perspective of management theory. A period followed during which, with assistance from the Ministry of Welfare, Health and Cultural Affairs (WVC), the project group set up by the Supervisory Committee on Academization in Primary Care (BAEG) made important contributions to further developing ideas on academization in the area of general practice.

The relevant international literature makes suggestions primarily in the area of affiliation collaboration, specifically for carrying out scientific research in general practice. Only to a very limited extent does it describe initiatives which are comparable with what in the Netherlands can be called "academization" or "academic workplaces".

Chapter 3 examines in more detail the Maastricht General Practice Academization Network (HAM) as developed at the University of Limburg. An analysis, in the form of a case study, is given of the recruitment and contracting of general practices, as well as the content and financing of the total network.

Developing academization in general practice according to network concepts has long been considered to be the most appropriate model. This is shown by, amongst other factors, the various reports of the Supervisory Committee on Academization in Primary Care.

Chapters 4 and 5 describe models for, respectively, approaching and collaborating with affiliated practices and academization of general practice. The model descriptions are based on a review of the literature and on actual experience. Retrospective consideration of the Maastricht academization model in the light of literature on business economics and business planning shows that there are five rellevant theories. Each of these, in its own way, provides an explanation of the process of academization of general practice and each is therefore discussed. In addition, the relationship is indicated between the literature discussed and theories of business economics on the one hand and HAM on the orher.

Five phases are distinguished within the model description of the approach to and collaboration with affiliated practices, namely preparation, acceptance, recruitment, implementation and follow-up.

The evaluation project group set up by the Supervisory Committee on Academization in Primary Care (BAEG) carried out a national study on the development of general practice academization networks in the Netherlands. This study is presented in chapter 6 , with the focus being on the aim, definition and the qualitative and quantitative description of the academization network.

Chapter 7 deals in more detail with the development of the academization network centred on the University of Limburg and examines not only the content but also the process and the results. A description is given of an evaluation study carried out by means of a questionnaire surveying 29 permanent members of the staff of 
the Department of General Practice and 55 "academized" GPs. Various aspects of academization were studied, such as aims and definition, optimum size of the network, the contractual relationship between the two parties, the selection of practices, quality control, possible changes in the way practices are managed and the influence of participation in the academization network on the way patient care is carried out. The results indicate not only that academization is important as a means of involving GPs in university teaching and research on a structural basis, but also that it has advantages for the GPs themselves. The "academized" GP considers that he is better able to practise his profession and that participation in the academization network brings him into contact with new elements.

Participation in academization requires adjustments, but the advantages for the GP would appear to outweigh the (slight) disadvantages, such as the need to make changes in the way the practice is managed.

Chapter 8 describes the general aspects of collaboration between the Department of General Practice at the University of Limburg and the GPS in the area covered by the University. What variables do the participating and non-participating GPs consider important in deciding whether or not to participate in scientific research carried out by the University? A survey of two representative sample groups --one of GPs who participate, either regularly or occasionally, in research conducted by the University of Limburg and one of GPs who do not-- makes it possible to examine what criteria are applied, what problems are experienced, what information the GP considers necessary before and after the research project, and the extent to which the GP's day-to-day activities are influenced by participation in scientific research. In general, there is a high level of readiness to participate in research. The most important factors in deciding whether or not to actually do so are interest in the topic and the strain or extra workload the project involves for the patient and the GP. Good feedback procedures are valued and a not inconsiderable number of GPs find it important that they are mentioned in some way or other as having participated. Approximately half the GPs in the survey find it reasonable that they should be remunerated for the extra time involved.

Adequate planning and coordination is clearly important in any type of collaboration. That is also the case in collaboration between the University and the GP. Do the GPs allow themselves to be "planned"? Chapter 9 attempts to provide an answer to this question. It considers the extent to which GPs who are participating in university research projects follow their own preferences with respect to the fields involved. "The results indicate that there is a link between the preferences stated by GPS and their actual participation in university projects. Even if there is no direct control in the form of a stratified approach strategy, the link between the figures before and after the project is generally clear. That this link is greater in the case of teaching projects than in that of research projects was to be expected.

The link is however such -right across the board-- that one may conclude that GPS decide to participate in a specific project primarily on the basis of their preferences with regard to its actual content. The suggestion is made that in future the approach strategy should be more closely keyed to the preferences indicated by the GPS. A more closely-targeted procedure for approaching and recruiting GPs for university projects may have advantages for both the University and the GPs. For the University, such an approach is probably more cost-effective, in view of the fact that at the 
moment (even for smaller projects) an approach is often made to all GPs in the region. For the GP, it is an advantage that he is not approached if he has indicated in advance that he has no interest in the specific topic involved. The number of times the practice is approached unnecessarily is therefore reduced considerably.

Chapter 10 deals with a number of management aspects of the Department of Generall Practice. Effective management of the Department is a prerequisite if there is to be optimum collaboration with the local GPS. The staff of the Department enjoy working within this organization and are positive about their work. There is a stronglyfelt need to produce good results and in general staff members consider that they make the maximum effort to achieve the results targeted. The flexible policy on working hours is also considered extremely important and is evaluated positively. The qualifications for posts within the Deparment are sufficiently clear and the staff have enough powers to be able to carry out their work effectively. The individuall worker feels, and is given, enough responsibility within his own area of activity. Staff members' opinions on supervision and monitoring are reasonably positive. One point of concern is the topic of "decision-making processes" and "consultative structures". "The respondents consider that it takes a great deal of time for decisions to be reached, allhough the quality of the decisions taken is none the better for that.

The longer staff have worked within the department, the higher the demands they make with respect to the aspects of planning, prowision of information, superwision and motivation and inspiration within the workplace. The higher the number of hours for which they are contracted (contract for $>0.5$ full-time post within the department), the more negative their opinion of the aspects of decisiveness and the provision of information.

There are differences between the scientific staff and the support staff as regards the way they perceive and experience the management of the department. The non-scientific staff, in particular, consider that mediocrity is to a considerable extent accepted, and in general that too much time is devoted to meetings and discussions. In addition, staff members in this category are given less responsibility for their own work and less encouragement to ake risks. Both categories feel to some extent that there is a difference in status between the scientific staff and the support staff.

In conclusion, chapter 11 is a general discussion. The collaboration between universities and GPs is discussed in broad terms. Suggestions for further research are made and the methodological shortcomings of the research described are considered. 


\section{CURRICULUM VITAE}

René Kocken werd op 2 november 1957 in Sittard geboren. Na voltooing van de Atheneum-studie aan de Albert Schweitzer Scholengemeenschap in Geleen, studeerde hij in 1980 af aan de commerciee-economische afstudeerrichting van de HEAO (Hoger Economisch en Administratief Onderwijs) te Sittard. Na volbrenging van de dienstplicht als sergeant-majoor der administratie starte hij zin loopban bij het Koninklijk Nederlands Ondernemers Verbond (KNOV), met als belangrijkste taak de woorlichting aan het zogenaamde midden- en kleinbedrijf over personeelsbeleid, medezeggenschap en reorganisaties. Eind 1982 aanvaardde René een functie als onderwijsmedewerker van het Faculteitsbureau van de Faculteit der Geneeskunde van de Rijksuniversiteit Limburg. In 1985 werd vervolgens de overstap gemaakt naar de vakgroep huisartsgeneeskunde, oorspronkelijk als beheerder en later gecombineerd met het coördinatorschap van het nieuw te creëren Coördinatiebureau Eerste Lijn (CEL). In deze latatste twee functies ontstond de eerste interesse voor de ontwikkeling wan 'eigen' onderzoeksprojecten, hetgeen in 1988 leidde tot de eerste (co-)auteurschappen. Als afgestudeerd HEAO'er bestond er een nadrukkelijke belangstelling woo" onderzoek op het grenswlak van de eerstelijn-gezondheidszorg enerzijds en organisatiekundige aspecten van die zorg anderzijds. Vandaar ook de keuze voor samenwerkingsaspecten tussen de universiteit en de praktizerende huisartsen.

Samen met de hoogleraren huisartsgeneeskunde heeft René Kocken belangrijke bijdragen geleverd aan de ontwikkeling van de academisering huisartsgeneeskunde, hetgeen de belangstelling voor dit onderwerp mede bepald heeft. Vanaf 1985 is René lid van het Dagelijks Bestuur van de vakgroep huisartsgeneeskunde, terwijl hij bovendien lid is geweest van het bestuur en de raad van de Faculteit der Geneeskunde (19861989) en secretaris van de Dagelijkse Commissie van de Examens (1983-1985). Vanaf 1 september 1994 makt hij wederom deel uit van het bestur van de Faculteit der Geneeskunde. Naast zijn huidige functie als hoofd van de sectie beheer en coördinatie wan de vakgroep huisartsgeneeskunde, besteedt hij aandacht an de internationalisering van de universiteit en van het huisartsgeneeskundige vak onder andere door de organisatie van congressen en internationale cursussen voor de zogenaamde European General Practice Research Workshop (EGPRW) en door zijn functie als coeditor van het European Journal of General Practice. 


\section{DANKWOORD}

Op deze plaats een woord van dank aan alle mensen die op enigerlei wijze een bijdrage hebben geleverd aan de totstandkoming van dit proefschrift.

De geacademiseerde buisartsen en bun assistentes, zoals in dit proefschrift met naam genoemd, verdienen uiteraard de meeste dank, aangezien zonder hen de ontwikkeling van een academiseringsnetwerk onmogelijk was geweest. Ook de niet-geacademiseerde huisartsen die incidenteel dan wel regelmatig met de Rijksuniversiteit Limburg samenwerken zijn zeer belangrijk geweest.

De medewerkers en oud-medewerkers van de sectie Beheer en Coördinatie van de vakgroep huisartsgeneeskunde hebben ieder op hun eigen wijze directe en indirecte bijdra gen geleverd aan dit proefschrift. Nicole Geraerts was de eerste secretaresse van de sectie en stond derhalve mede aan de basis van de sterk toegenomen samenwerking met de regionale huisartsen. Haar niet-aflatend enthousiasme en haar jeugdig elan deden de ontbrekende werkervaring als sneeuw voor de zon verdwijnen. Helaas verdween ook zij, ondat de liefde voor een man sterker bleek dat haar liefde woor het werk bij onze sectie. Hanny Prick volgcle haar op en was behulpzaam bij alle secretarièle en organisatorische werkzaamheden, die ten grondslag liggen aan het gepresenteerde onderzoek. Haar positieve uitstraling en aparte humor waren steeds weer een bron van inspiratie. Cecile Nijland kwam als voorlatste bij de sectie en heeft in indirecte zin bijdragen geleverd. Een woord van dank is op zijn plaats, aangezien haar aanwezigheid de mogelijkheid voor mij opende om gedurende de laatste maanden meerdere dagen thuis het manuscript af te ronden, terwijl ik wist dat de werkzaamheden bij de vakgroep in goede handen waren. Ik hoop nog lang van haar intelligentie, rust en daadkracht gebruik te mogen blijven maken.

Het jongste blaadje aan de beheerstak is Maria Habets. Haar parttime aanwezigheid maken de dinsdag en donderdag tot speciale momenten van de week.

Aan een aantal onderzoeken werden belangrijke bijdragen geteverd door "derden", alhoewel het woord 'derden' hier eigenlijk niet op zijn plaats is, aangezien het een zekere afstand suggereert. Die afstand was er geenszins. Anja Prenger-Duchateau was destijds huisarts-in-opleiding en vroeg mij een onderzoek naar samenwerkingsaspecten te begeleiden. Het project leidde tot een succesvolle afronding wan haar huisartsopleiding en leverde belangrijk materiaal voor éen van mijn eerste artikelen. Haar grote inspanningen voor het onderzoek hebben mij er toe gebracht op dit terrein meerder onderzoeken te ontwikkelen. Ik bedank haar voor de uitzonderiijke inspanning bij dit onderzoek.

Ook Matb Muris, geacademiseerd huisarts in het Gezondheidscentrum Neerbeek, was betrokken bij één van de onderzoeken. Zijn zeet praktische kijk op de materie en zijn heldere visie op het spanningsveld tussen de universiteit en de praktizerende huisarts hebben mij steeds weer aan het denken gezet en deden mij steeds weer afdalen uit de 'iworen toren' van de universiteit. 
In de projectgroep Evaluatie van de Begeleidingscommissie Academisering Eerstelipns Gezondheidszorg (BAEG) werkte ik als vertegenwoordiger van de Rijksuniversiteit Limburg en de Katholieke Universiteit Nijmegen onder leiding van Prof.dr. Bert Scbadé, hoogleraar huisartsgeneeskunde Universiteit van Amsterdam. Alhoewel wij over de aanpak soms verschillende meningen hadden, zagen wij beiden de absolute noodzaak van structurering van de samenwerking tussen universiteiten en zorgverleners in de eerste lijn. De vereiste financiering van deze academiseringsnetwerken was voor ons beiden een belangrijk en tegelij|kertijd onduidelijk toekomstperspectief. Van Bert leerde ik dat het tempo waarin de huisartsgeneeskundige netwerken totstand kunnen worden gebracht voor een belangrijk gedeelte afhangt van de snelheid waarmee de politieke molens in de toekomst zullen draaien.

In dezelfde projectgroep kwam ik in contact met Frank Ooms, huisarts te Zwammerdam, tevens verbonden aan de Rijksuniversiteit Leiden en Hans Meijer, huisarts te Amsterdam en verbonden aan de Universiteit van Amsterdam. Onze periodieke ontmoetingen in het Academisch Medisch Centrum in Amsterdam waren belangrijk in het proces van verdere idee-ontwikkeling inzake academisering huisartsgeneeskunde. Het is jammer dat onze gezamenlijke impulsen (nog) niet geleid hebben tot meer universitaire initiatieven om te komen tot academiseringsnetwerken huisartsgeneeskunde. Onze inspanningen zullen wel niet voor niks zijn geweest. Ze hebben mij in ieder geval nuttig materiaal voor dit proefschrift opgeleverd.

Alhoewel het gepresenteerde onderzoek niet uitblinkt in ingewikkelde methodologie en statistiek, zijn er vele analyses door Paula Smeets-Rinkens uitgevoerd. Steeds weer was zij bereid nieuwe analyses uit te voeren, zonder dat haar opgewekte humeur verdween. Zonder anderen te kort te willen doen, denk ik oprecht te kunnen stellen dat haar medewerking aan dit proefschrift van grote waarde is geweest. Niet alleen de verzorging van de analyse en de gezamenlijk uitvoering van het onderzoek naar management-aspecten in de vakgroep huisartsgeneeskunde waren voor mij belangrijk. Belangrijker nog waren haar voortdurende stimulans en kritische opstelling bij alle onderdelen van dit proefschrift. Als een moeder waakte zij over het materiaal en de voortgang, terwijl het moederschap haar op dat moment nog vreemd was. Inmiddels hoeft zij geen moederlijke zorgen meer te hebben voor dit proefschrift, maar kan zij zich geheel wijden aan de op 5 januari 1994 geboren eigen baby, Sera en het opkomst zijnde nieuwe famillelid.

Ellen Breevoort is bewust eerder niet genoemd bij de medewerkers van de sectie Beheer en Coördinatie, terwijl zil wel degelijk één van de medewerkers van deze sectie is. Haar bedanken moet dan ook op deze aparte plaats, aangezien zij veel indirecte bijdragen aan het proefschrift heeft geleverd. Zeer plichtsgetrouw en met een excellent gevoel voor zowel de belangen van de vakgroep als van het regionale veld verzorgt $2 \mathrm{ij}$ de laatste twee jaren de werkzaamheden op het gebied van de coördinatie van het universitaire onderwijs en onderzoek. Haar vrouwelijk instinct zal ik nooit kunnen evenaren, evenals haar vermogen om snel van anderen te leren. Van leergierig medewerker ontwikkelt zij zich gestaag tot deskundig meester op het terrein van de samenwerking en academisering. Toekomstige publikaties op dit terrein worden dan ook van haar verwacht. De verdere ontwikkeling van het Huisartsgeneeskundig Academiseringsnetwerk Maastricht jigt mede in haar vertrouwde handen. Ik wens haar daarbij veel succes. 
1k voel het niet als een morele plicht, maar als een welverdiend gebaar om ook mijn promotoren te bedanken.

Hamy Grebolder kwam als Eerstelijns Onderwijscoördinator bij de Faculteit der Geneeskunde. Al snel maakte hij duidelijk hoogleralar huisartsgeneeskunde te zijn met een primaire belangstelling voor de plaats van de praktizerende huisarts in het onderwijsen onderzoekprogramma van de universiteit. Als er ergens een liefde-haat verhouding bestaat dan is het wel tussen Harry en mij. Overeenstemming is er doorgaans over de einddoelen die nagestreefd worden; verschil van mening over de wegen waarlangs de doelen bereikt moeten worden. Het is mij pas later duidelijk geworden dat twee zo verschillend denkende mensen op één tandem zou moeten leiden tot een winnend duo.

Naast Harry was André Knotnerus de grote animator van dit proefschrift. Hij was betrokken bij alle onderzoeken en niet alleen vanwege zijn methodologische en statistieke deskundigheid. Zijn voortdurende beschikbaarheid en bereidheid om mee te denken over allerlei vraagstukken waren van evident belang. En alhoewel hij van zichzelf vind.t geen goed manager te zijn, heeft hij in ieder geval één belangrijke eigenschap van een uitstekend manager, namelijk het vermogen om steeds weer te motiveren. Zoals elke promovendus maakte ook ik periodes mee, waarin ik dacht de eindstreep niet te kunnen halen. Steeds weer was het André die op zijn geheel eigen wijze nieuwe zuurstof toediende, waarna de volgende pagina's van het proefschrift bijna vanzelf uit de pen te voorschijn kwamen. Naast zijn motivatie-technieken heeft André mer zijn originaliteit, creativiteit en gevoel voor detail belangrijke bijdragen geleverd aan de totstandkoming van alle hoofdstukken van dit proefschrift.

Jos Blommaent was voor mij een oude bekende. Als leerling aan de HEAO ontmoette ik hem als leraar Bedrijfsorganisatie. Mijn liefde voor het vak bedrijfsorganisatie en voor management-aspecten heb ik dan ook geheel aan hem te danken. Jaren later ontmoette ik hem als collega bij de Rijksuniversiteit Limburg, werkzaam bij de vakgroep Berichtgeving van de Faculteit der Economische Wetenschappen. Toen ik hem vroeg mij behulpzaam te zijn bij mijn promotie was hij meteen zeer enthousiast. Zijn bijcrage was onontbeerlijik op de specifieke organisatorische en model-theoretische terreinen van dit proefschrift. Zijn groot enthousiasme was voor mij een grote stimulans in de laatste, voor alle promovendi ingewikkelde, fase van afronding van het proefschrift. Wellicht dat zijn bijdrage aan mijn proefschrift de afronding van zijn eigen dissertatie heeft versneld. Het kan toch geen toeval zijn dat hij zes dagen na deze promotie zijn eigen proefschrift zal verdedigen.

Mijn ouders gaven mij belangrijke gedeeltes van het gereedschap dat nodig is om een proefschrift af te ronden. Mijn moeder gaf het vermogen om nieuwe dingen zonder vrees te willen ontdekken, een nieuwsgierigheid die elke onderzoeker moet hebben. Van haar erfde ik ook de praktische instelling, het noodzakelijk 'ongeduld' en her leeftempo. Van mijn vader ontving ik meer erfelijk materiaal. Belangstelling voor studie en werk in de juiste afwisseling met de ander geneugten van het leven (muziek, sport), vermogen tot concentratie en verdieping, een positieve werkattitude, aandacht voor andere werkers in de organisatie en geloof in eigen kunnen zijn slechts enkele dingen die ik van hem gekregen en geleerd heb. Op vele momenten is hun voorbeeld actief aanwezig in mijn geheugen. 
Mijn gezin is altijd belangrijk voor mij geweest. Vandaar dat ik geprobeerd heb dat Anita, Tim en Dennis zo min mogelijk 'last' hadden van mijn activiteiten in verband met dit proefschrift. Vooral de laatste maanden maakten zij het mogelijk dat ongestoord en in een weldadige en motiverende rust aan de afronding van het proefschrift kon worden gewerkt. Anita wilde liever niet vermeld worden, hetgeen haar altijd bescheiden opstelling treffend typeert. Door haar vermogen zich geheel weg te ciffewen voor het gezin was het voor mij relatief eenvoudig de aandacht in de afgelopen periode met name te richten op de afronding van dit proefschrift. Haar hier niet te vermelden (conform haar verzoek) zou geschiedvervalsing zijn. 
APPENDIX A

OVERZICHT HUISARTSPRAKTIJKEN

VAN HET HUISARTSGENEESKUNDIG

ACADEMISERINGSNETWERK MAASTRICHT (HAM) 
1. Gezondheidscentrum Neenbek

Kerklaan 11,6191 GM Neerbeek

\section{Gezondheidscentrum}

\section{Huisartsen}

Muris MHNM

Eyck MAMF

Winten-Huisman MT.

Leeuwen van YD

\section{Dokterassistent(e)(n)}

Cuypers $M$

Penders $\mathrm{C}$

Schols K

Ramaekers A
Financieringsbron

Stimuleringsregeling UHP

Geld

Samenwerkingsomvang 0.4 Fte
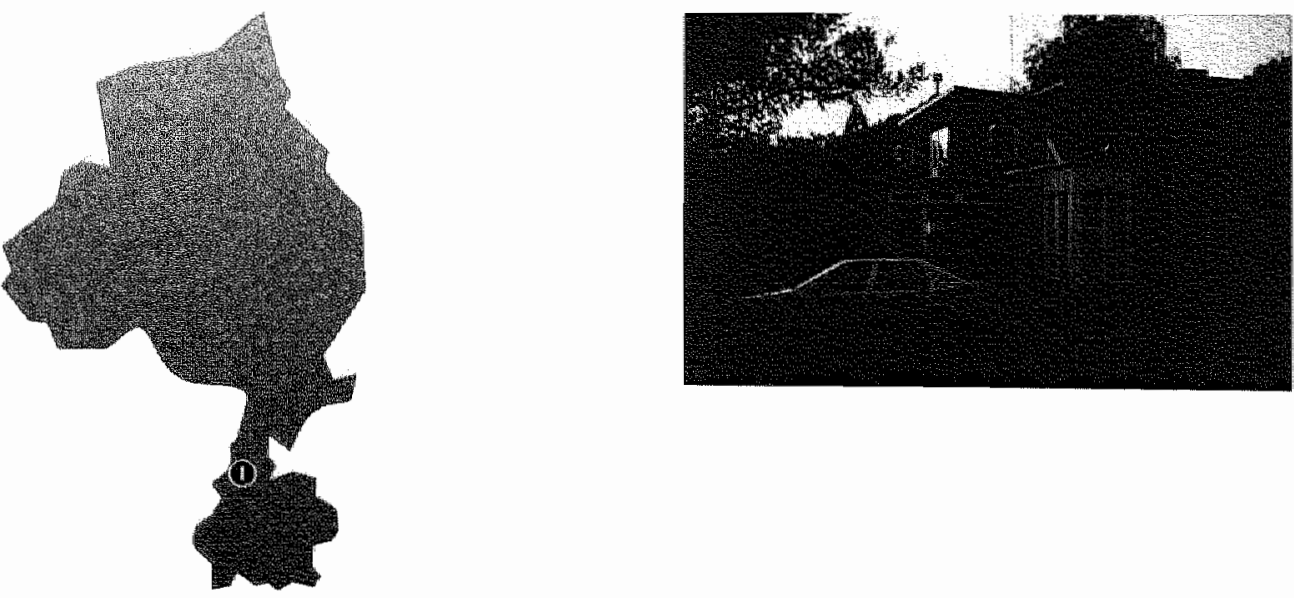
A ge Water 20,6451 CD Schinveld

\section{Gezondheidscentrum}

\section{Huisartsen}

Hermans JJH

Tummers EL
Dokterassistent(e)(n)

Janssen-Cremers AHG Meis-van der Vorst MHT

Beckers DJH

\section{Financieringsbron}

Vernieuwingsfonds

Aanstelling bij RL.

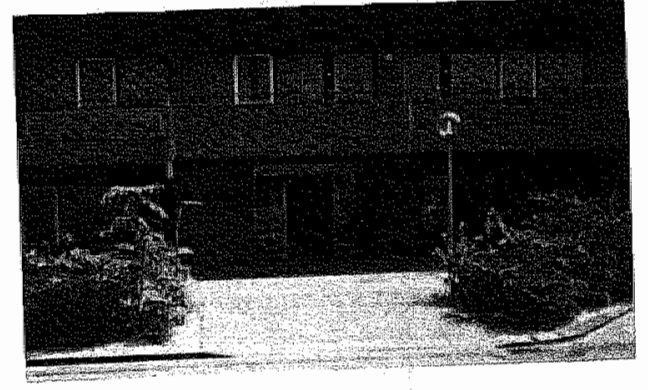

Samenwerkingsomvang 0.15 Fte

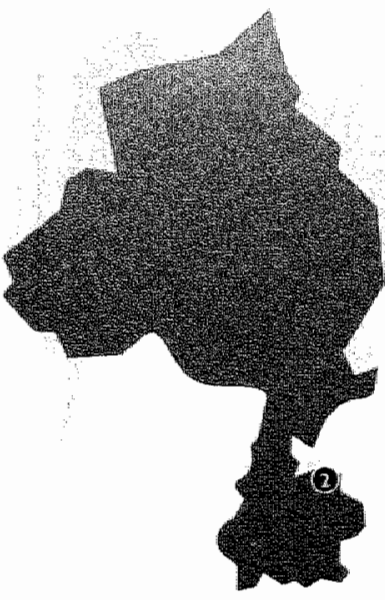


3. Gezondheidscentrim de Hofhod.

Penatenhof $88,6215 \mathrm{BV}$ Maastricht

\section{Gezondheidscentrum}

Huisartsen

Vierhout WPM

Beusmans GHMI

Verwijnen GM

\section{Dokterassistent $(e)(n)$}

Coenen-Boers MLH

Willems AWA

Leenders MECM
Financieringsbron

Vernieuwingsfonds

Aanstelling bij RL

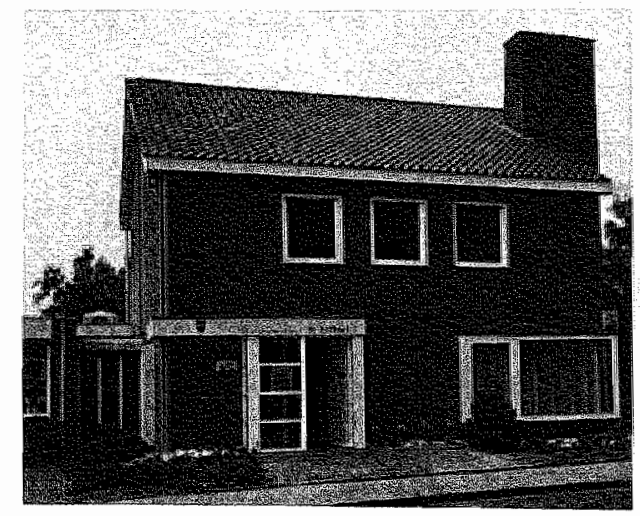

Samenwerkingsomvang 0.6 Fte

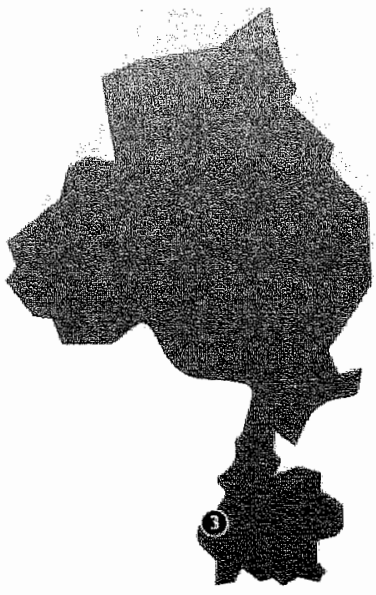




\section{Gezondheidseentrum de Maar}

Caumerstraat 11, 6467 GH Kerkrade

\section{Gezondheidscentrum}

\section{Huisartsen}

Michels IJ

Zanten van $G$

Wissel van der HAWJ

Ree van JW

\section{Dokterassistent(e)(n)}

Horst van der $\mathrm{N}$

Lubbers NMJ

Rutzerveld-Verspagen GM]
Financieringswijze

Menskracht tegen menskracht Geld

\section{Financieringsbron}

Stimuleringsregeling UHP

Samenwerkingsomvang 0.3 Fte
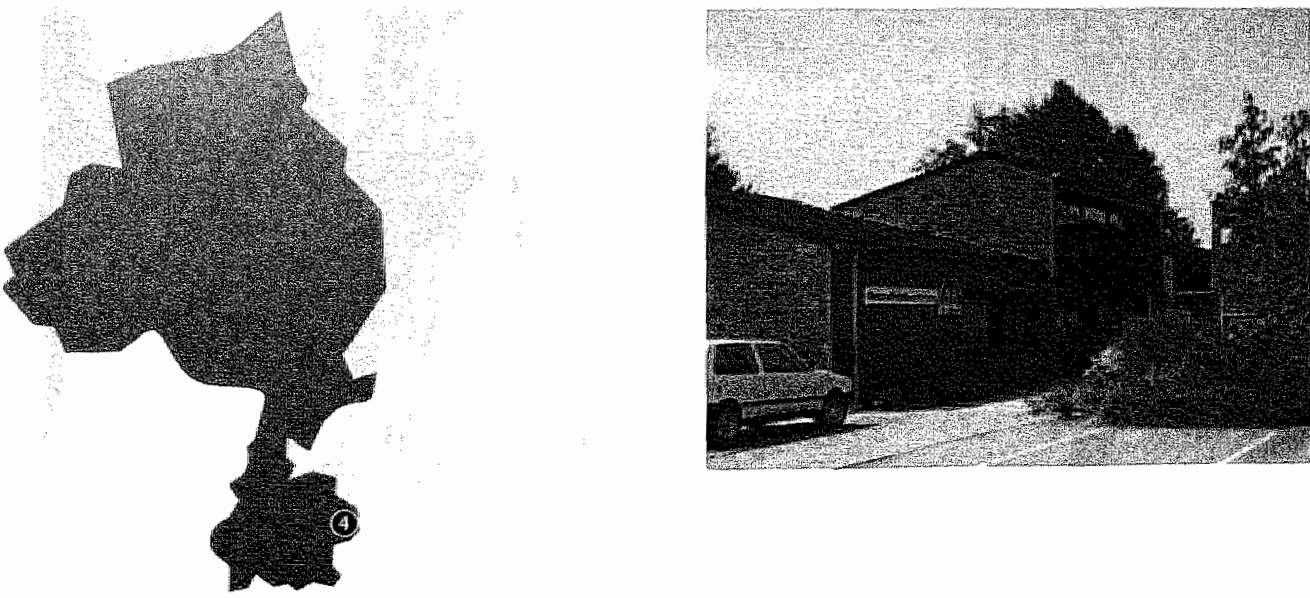
Mauritsweg 3, 6171 RM Stein

\section{Gezondheidscentrum}

\section{Huisartsen}

Govaert ThME

Leclercq RMPM

Dinant GJ

\section{Dokterassistent(e)(n)}

Nijsten-Spoor BMHL

Penris MBA

Smit $H$

\section{Financieringswijze}

Menskracht tegen menskracht
Financieringsbron

Venieuwingsfonds

\section{Samenwerkingsomvang 1.0 Fire}
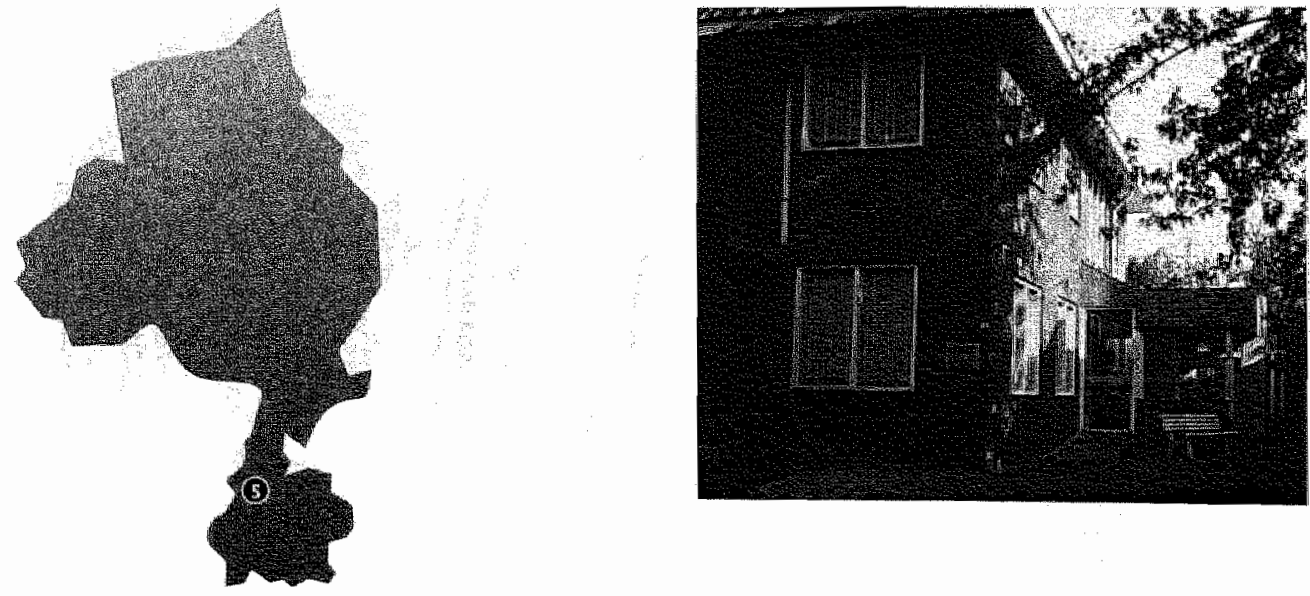
6. 1: Huisaritsenpraktik Vocrendaal

Raadhuisplein 4,6367 ED Voerendaal

\section{Gezondheidscentrum}

\section{Huisartsen}

Panhuysen RAM

Guldemond-Hecker ETIM

Hulshof PBN

\section{Dokterassistent(e)(n)}

Hundscheid DDA

Kamps $M$

Muris EMC

Panhuysen-Delwaide MDMMG

Schoot van der-Klaassen]

\section{Financieringswijze}

Aanstellingen bij RL

\section{Financieringsbron}

Vernieuwingsfonds

Samenwerkingsomvang 0.3 Fte
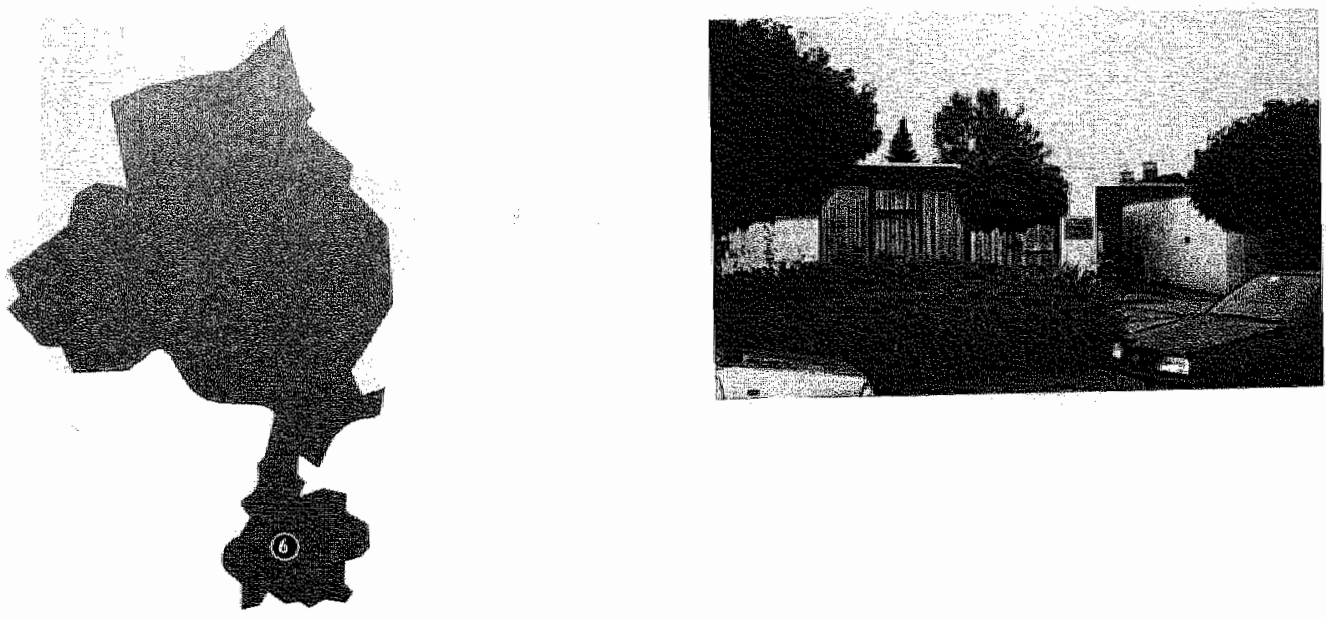
7. 4 Muisartspraktik Jans ma

Kloosterstraat 12, $5941 \mathrm{ET}^{\circ}$ Velden

Solo-praktijk

Huisartsen

Jansma JPM
Dokterassistent(e)(n)

Theeuwen CPE
Financieringswijze

Aanstelling bij RL
Financieringsbron

Vernieuwingsfonds

Samenwerkingsomvang 0.1 Fte
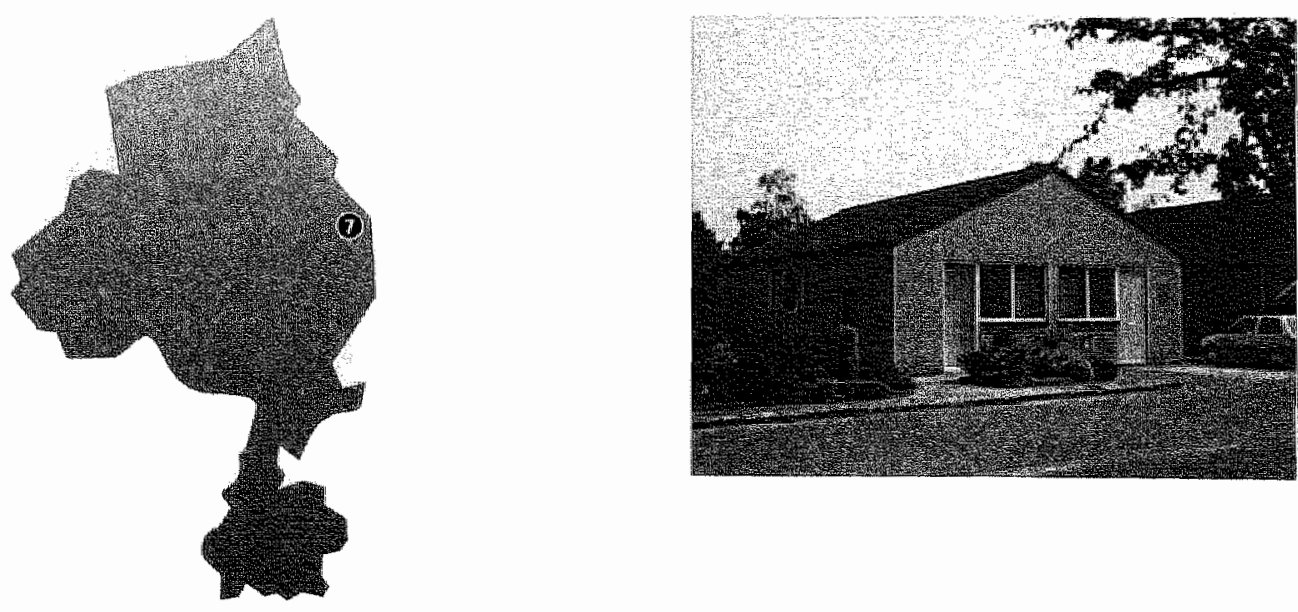
8. 1. 1Hisartspraktik Op den Kamp

Willemstraat 62,6412 AT Heerlen

Solo-praktijk met toegevoegd RL-arts

\section{Huisartsen}

Op den Kamp M

Maiburg HJS

\section{Dokterassistent(e)(n)}

Boesten ECH

\section{Financieringsbron}

Vernieuwingsfonds

Aanstelling bij RL

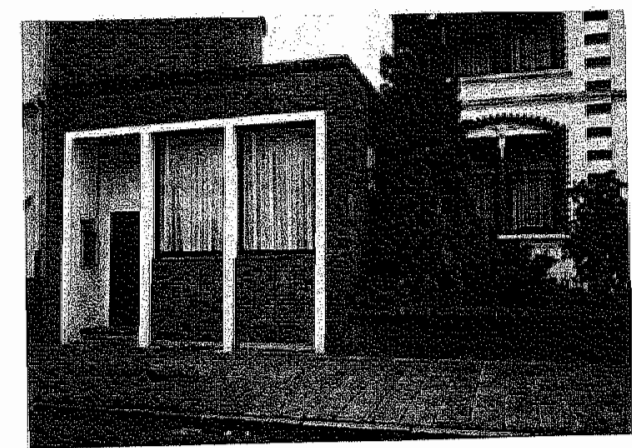

Samenwerkingsomvang 0.1 Fte

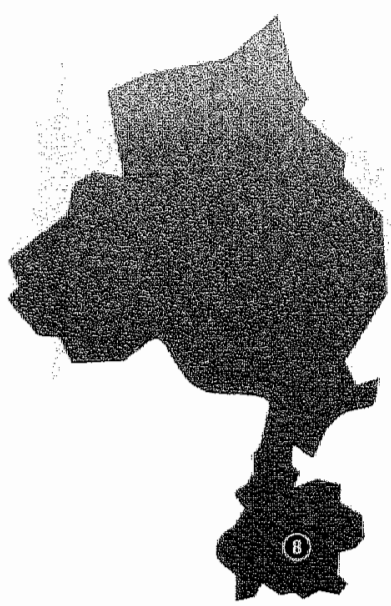


Putstraat 32,6372 BKK Landgraaf

\section{Gezondheidscentrum}

\section{Huisartsen}

Ypma JAM

Eussen JHM

Stuurman CLSM

\section{Dokterassistent(e)(n)}

Ploum FJG

Pommé VLMH

Ewijk van AEW

\section{Financieringsbron}

Vernieuwingsfonds

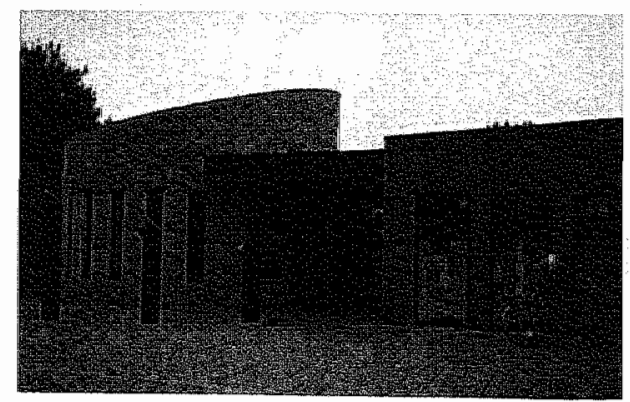

Samenwerkingsomvang 0.3 Fte

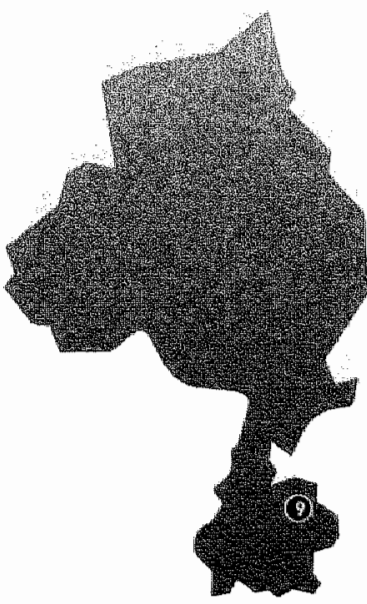




\section{1) Gezondheidscentrum Withuis}

Straelseweg 193, 5914 AL Venlo

\section{Gezondheidscentrum}

\section{Huisartsen}

Dam van $\mathrm{HA}$

Jansen PJ

Kessel van AJL

Koning de $\mathrm{G}$

Vlek JFM

\section{Dokterassistent(e)(n)}

Maas A

Nefkens MJ

Versteegen $C$

Kuypers $\mathrm{S}$

Hendriks A

Gerven van T

Bijker J (aclm.coürdinator)

\section{Financieringswijze}

Aanstellingen bij RL

\section{Financieringsbron}

Vernieuwingsfonds

Samenwerkingsomvang 0.8 Fte
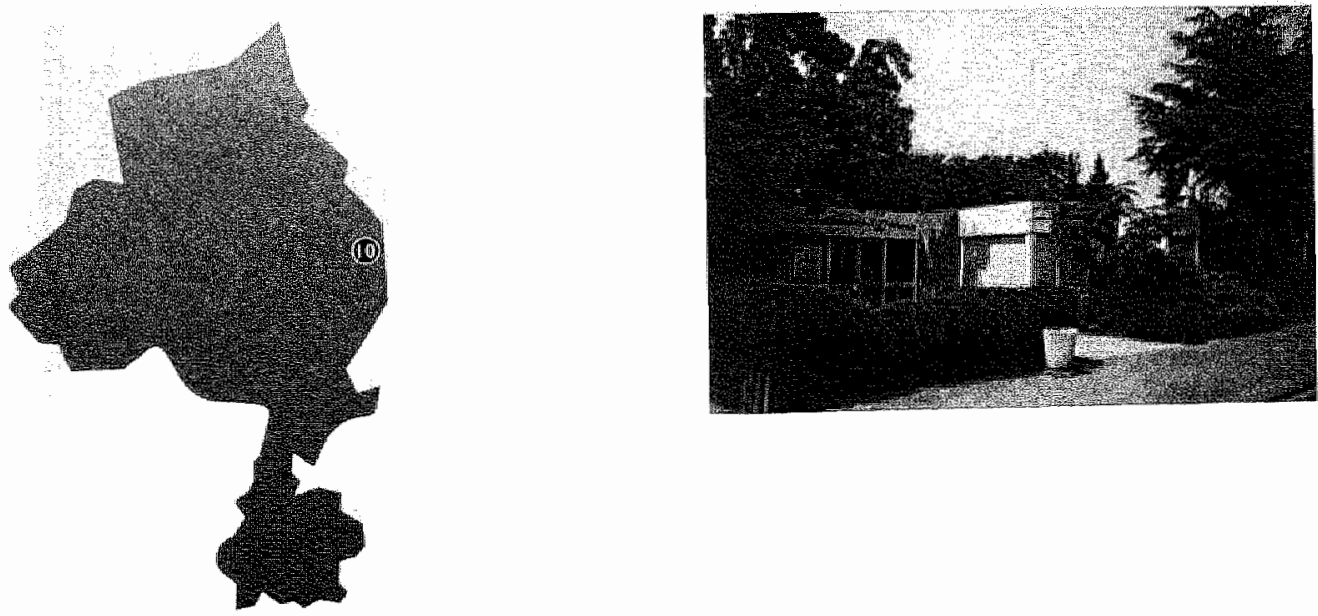


\subsection{Gezolidheidscentrum Heer}

Pastoor Heimenstraat 2, 6227 TE Maastricht

\section{Gexondheidscentrum}

\section{Huisartsen}

Muysken-du Saar AM

Peeters MP

Vissers FH
Dokterassistent(e)(n)

Bruyn de-Höppener ML

Frijns $M$

Smeets WW

\section{Financieringsbron}

Vernieuwingsfonds

Stimuleringsregeling UHP

Samenwerkingsomvang 0.7 Fte
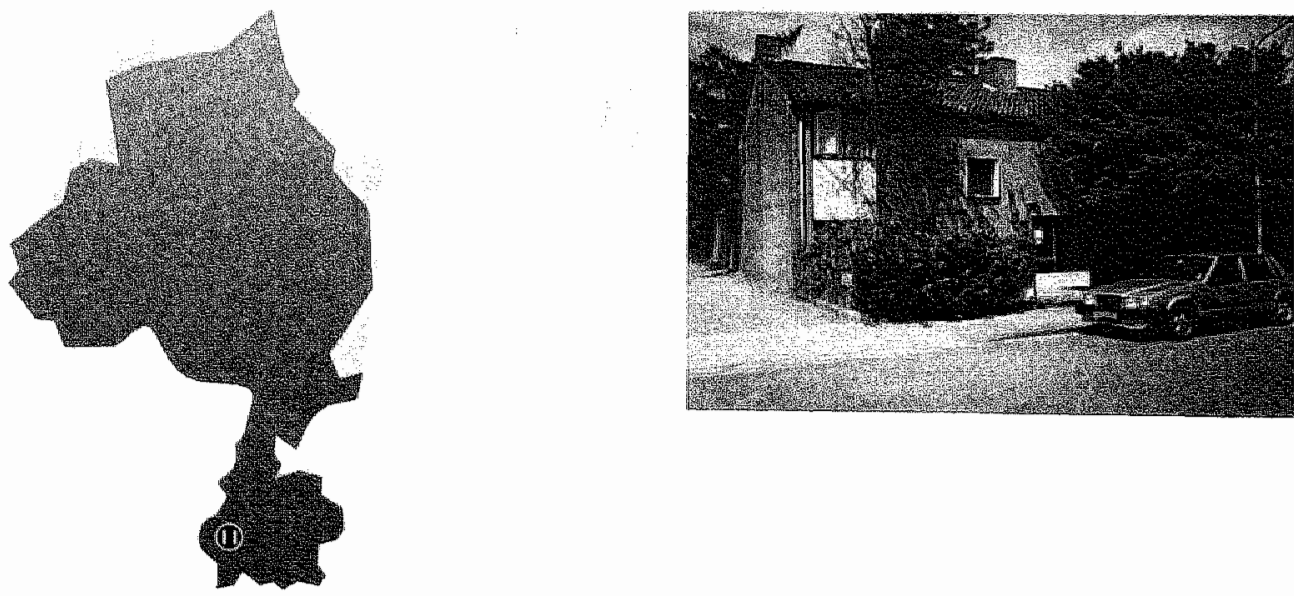


\section{1: Tuisartsennaatschap w, d. Voont Bromwers}

Hoofdstraat 93, 6432 GA Hoensbroek

\section{Gezondheidscentrum}

\section{Huisartsen}

Voort van der DJM

Brouwers RHI

Martens F

\section{Dokterassistent(e)(n)}

Mertens J

Dupont B

Dibbets A

\section{Financieringsbron}

Stimuleringsregeling UHP

Menskracht tegen menskracht

Geld

Samenwerkingsomvang $0.2 \mathrm{Fte}$
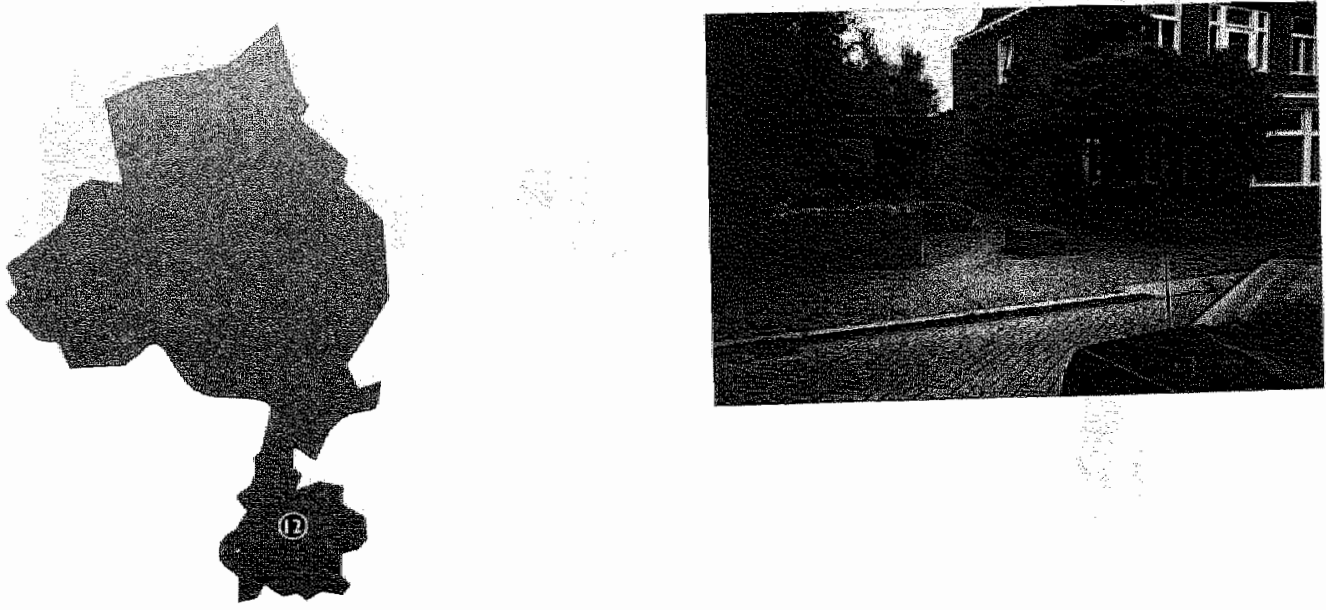
13. Huisartspraktih Visse liedilk/Massuger

Verstraelenstraat $13,6097 \mathrm{CJ}$ Heel

\section{Groepspraktijk}

Huisartsen

Visschedijk AB

Massuger AFMC

\section{Dokterassistent(e)(n)}

Macco Th

Maessen MMJ

\section{Financieringswijze}

Aanstelling bij RL.

\section{Financieringsbron}

Vernieuwingsfonds

Samenwerkingsomvang 0.1 Fte
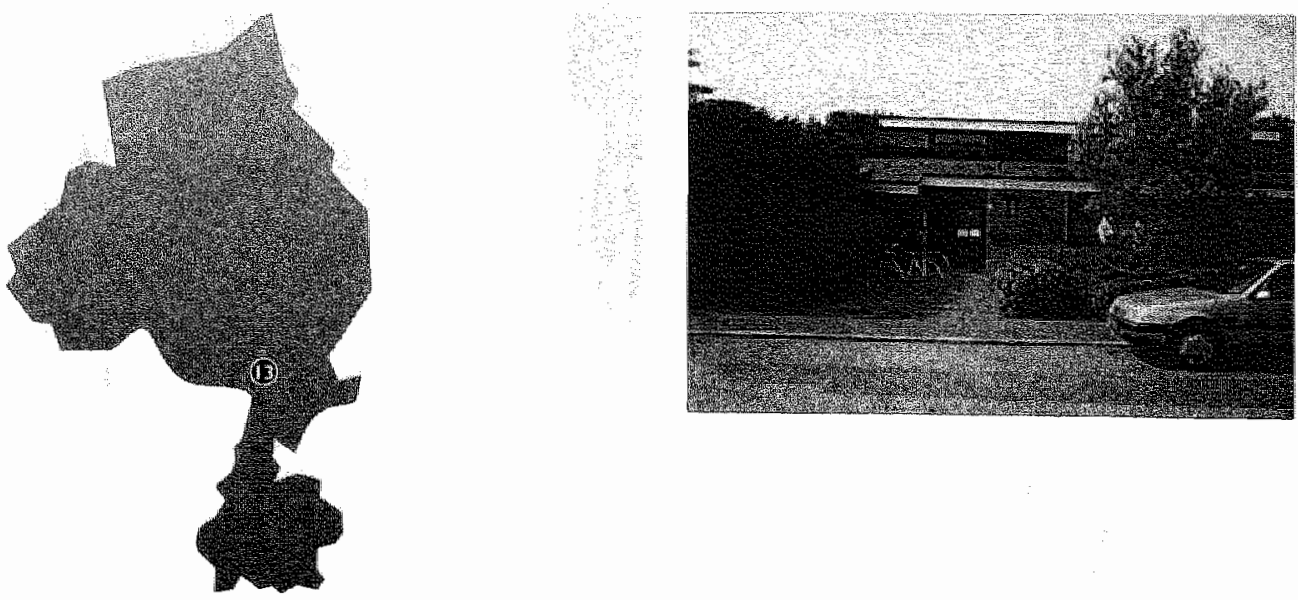
14 I Muisaitspraktijk de wit

Akerstraat 89, 6417 BK Heerlen

\section{Solo-praktijk}

Huisartsen

Wit de AAM

\section{Dokterassistent(e)(n)}

Cuypers PMA

Veldman I

\section{Financieringsbron}

Vernieuwingsfonds

Aanstelling bij RL

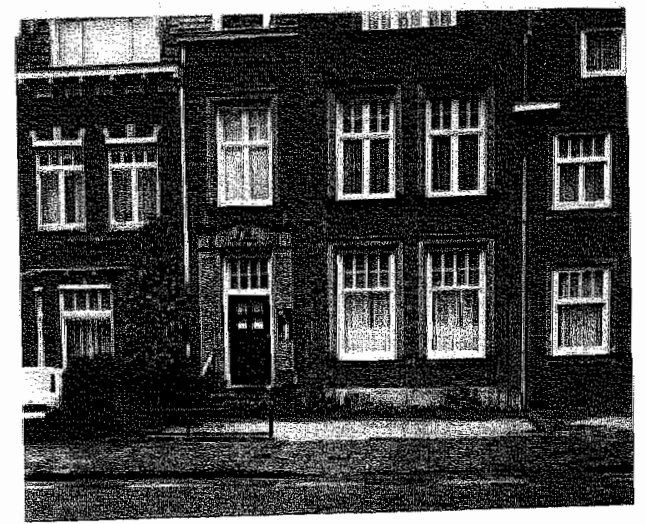

Samenwerkingsonvang 0.1 Fte

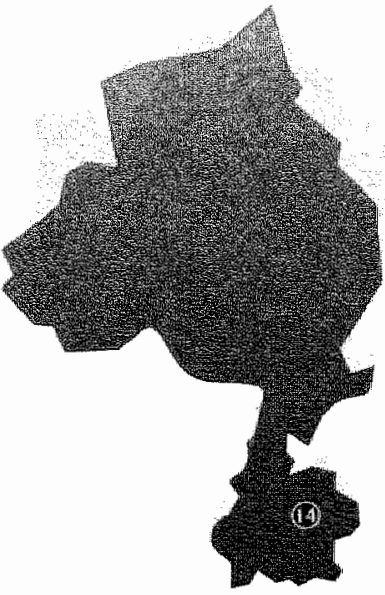


15. Huisartsprakith 2wietering

Meerssenerweg 142, 6222 AK Maastricht

\section{Solo-praktijk}

\section{Huisartsen}

Zwietering VA

\section{Dokterassistent(e)(n)}

Meuwissen ICHO

Muijtjens-Janssen MJE

\section{Financieringsbron}

Vernieuwingsfonds

Aanstelling bij RL

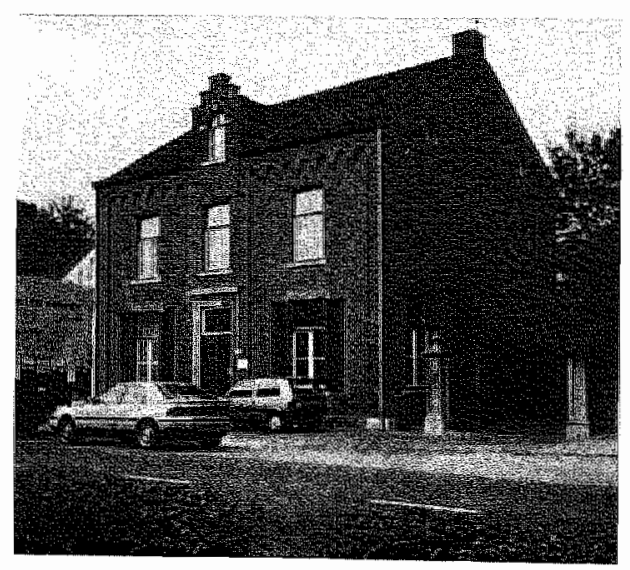

Samenwerkingsomvang 0.1 Fte

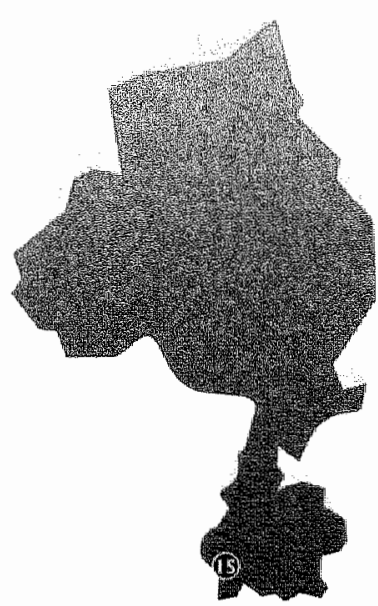




\section{6. d Huisartsprakthlk Gevile}

Marktplein (rijdelijk adres), Geulle

\section{Groepspraktijk}

\section{Huisartsen}

Metsemakers JFM

Muris JWM

Zwietering $\mathrm{P}$ ]

\section{Dokterassistent(e)(n)}

Smeets-Gerets M

Welzen-Lacroix $Y$

Keysers-Hoen K.

\section{Financieringsbron}

Vernieuwingsfonds

Aanstellingen bij RL

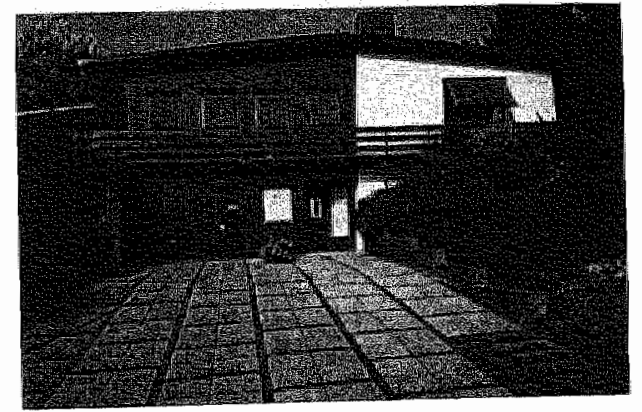

Samenwerkingsomvang 1.2 Fte

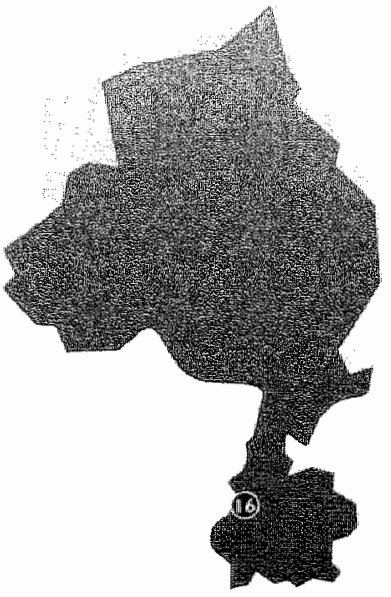


17.1 Huisants praktjlk Ubachiberg

Hunsstraat 71, 6367 JK Ubachsberg

Solo-praktijk

Huisartsen

Guldemond FI

Financieringswijze

Aanstelling bij RL

\section{Dokterassistent(e)(n)}

Spierts JAM

\section{Financieringsbron}

Vernieuwingsfonds

Samenwerkingsomvang 0.1 Fte
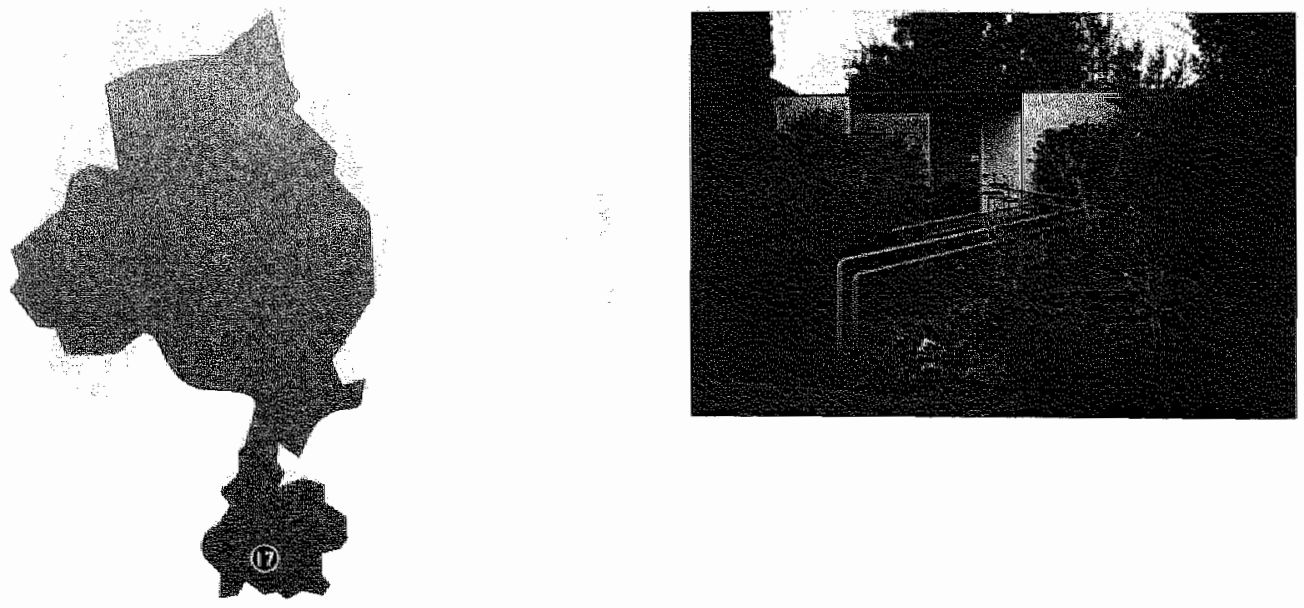
18 1 inisartspraktil De grote schumr

Kasteellaan 17,5855 AD Well

\section{Gezondheidscentrum}

\section{Huisartsen}

Schönberger HJAM

Putten van MTJ

Broek van den WEM

\section{Dokterassistent(e)(n)}

Hendriks $Y$

Gelder van $C$

\section{Financieringsbron}

Financieringswijze

Aanstellingen bij RL
Vernieuwingslonds

Samenwerkingsomvang 0.3 Fte
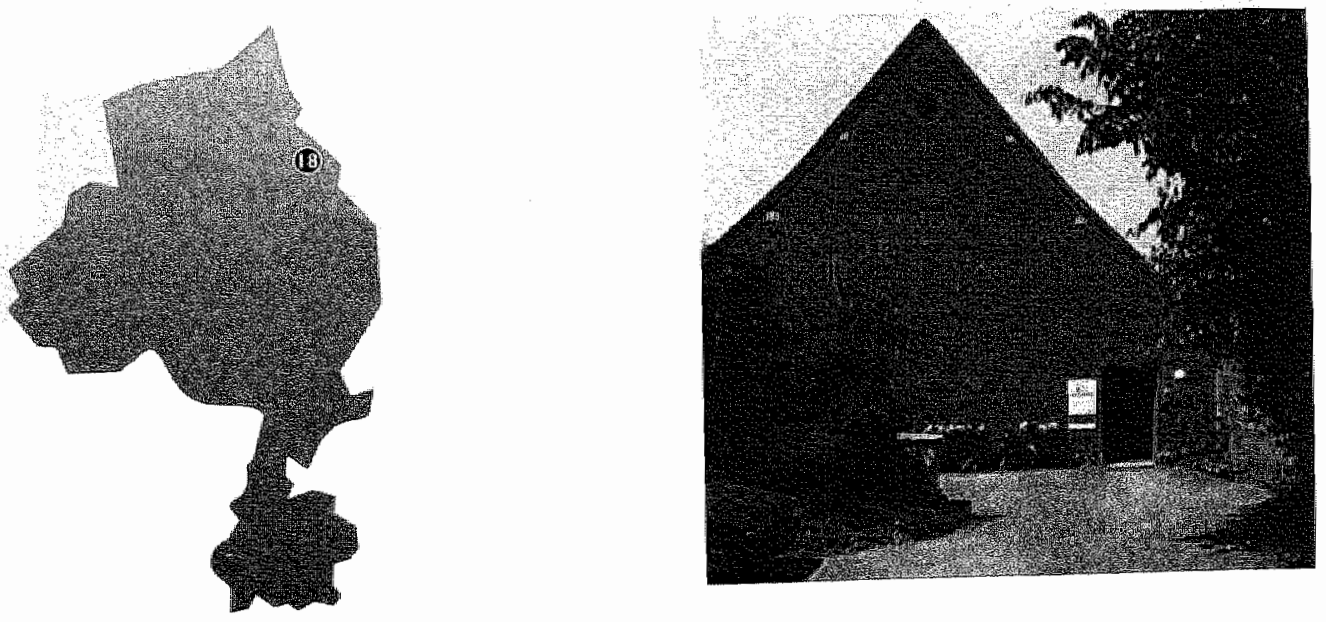
19. 4 Gezondheldscentrum

Hoensbrockeroord

Akerstraat Noord 74, 6431 HN Hoensbroek

\section{Gezondheidscentrum}

\section{Huisartsen}

Schendel van GI

Paas JPJ

Venrooy van $\mathrm{MH}$

Nunen $\operatorname{van} M$

Voorhoeve PM

Helmers RJH

Zwanikken $\mathrm{H}$

Beek van $M$

\section{Dokterassistent(e)(n)}

Schils W

Mevissen $M$

Schols I

Rosier M

Erens $M$

Leers $\mathrm{P}$

\section{Financieringswijze}

Menskracht tegen menskracht

\section{Financieringsbron}

Vernieuwingsfonds

Samenwerkingsomvang 1.3 Fte
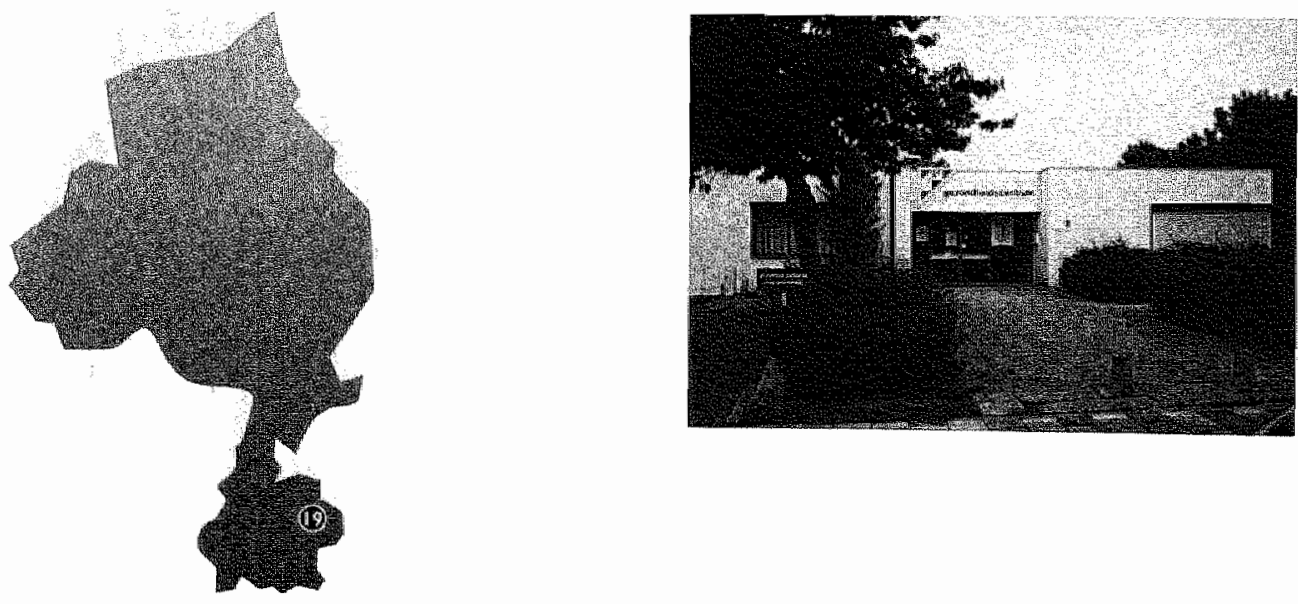


\section{I Iuisartspraktifk Boesten Jochems}

Dorine Verschureplein 10b, 6181 AS Elsloo

\section{Groepspraktijk}

\section{Huisartsen}

Jochems HMJ

Boesten HMJ

\section{Dokterassistent(e)(n)}

Nijsten-Geisen CMGM

Botermans SAAM

\section{Financieringswijze}

Aanstellingen bij RL

\section{Financieringsbron}

Vernieuwingsfonds

Samenwerkingsomvang 0.2 Fte
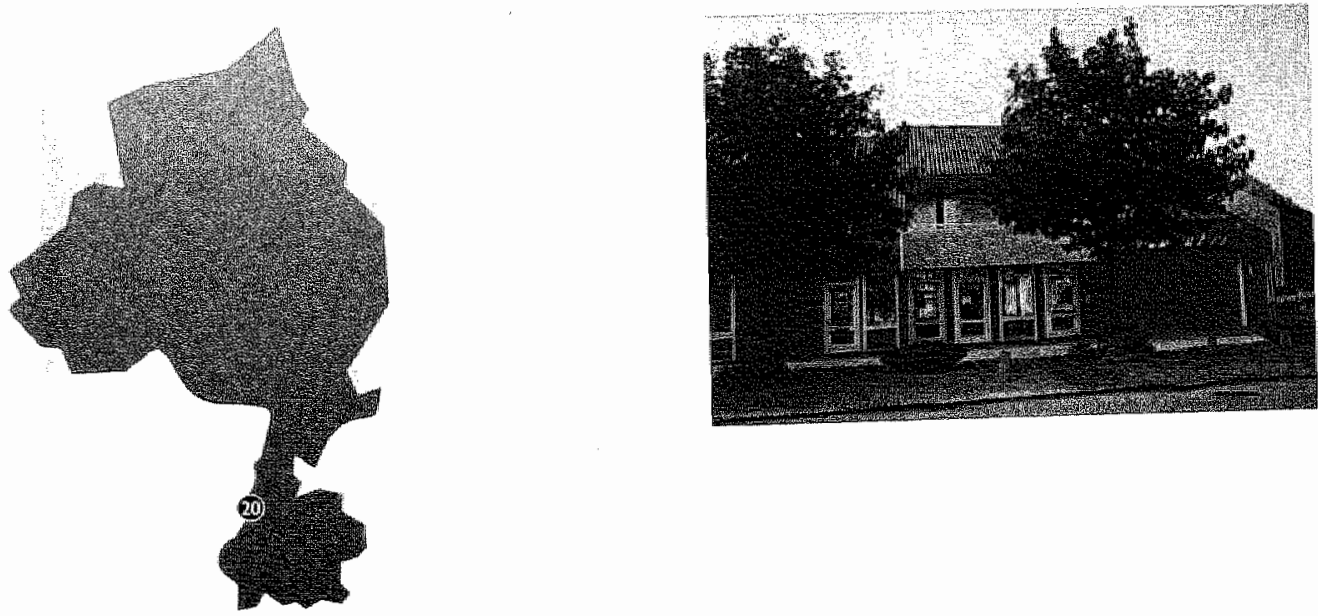
veldhofstraat 26, $6471 \mathrm{CK}$ Eygelshoven

\section{Groepspraktijk}

\section{Huisartsen}

Kaiser $\mathrm{V}$

Veldhuizen JW

\section{Dokterassistent(e)(n)}

Meurs I

\section{Financieringswijze}

Aanstellingen bij RL

\section{Financieringsbron}

Vernieuwingsfonds

Samenwerkingsomvang $0.4 \mathrm{Fte}$
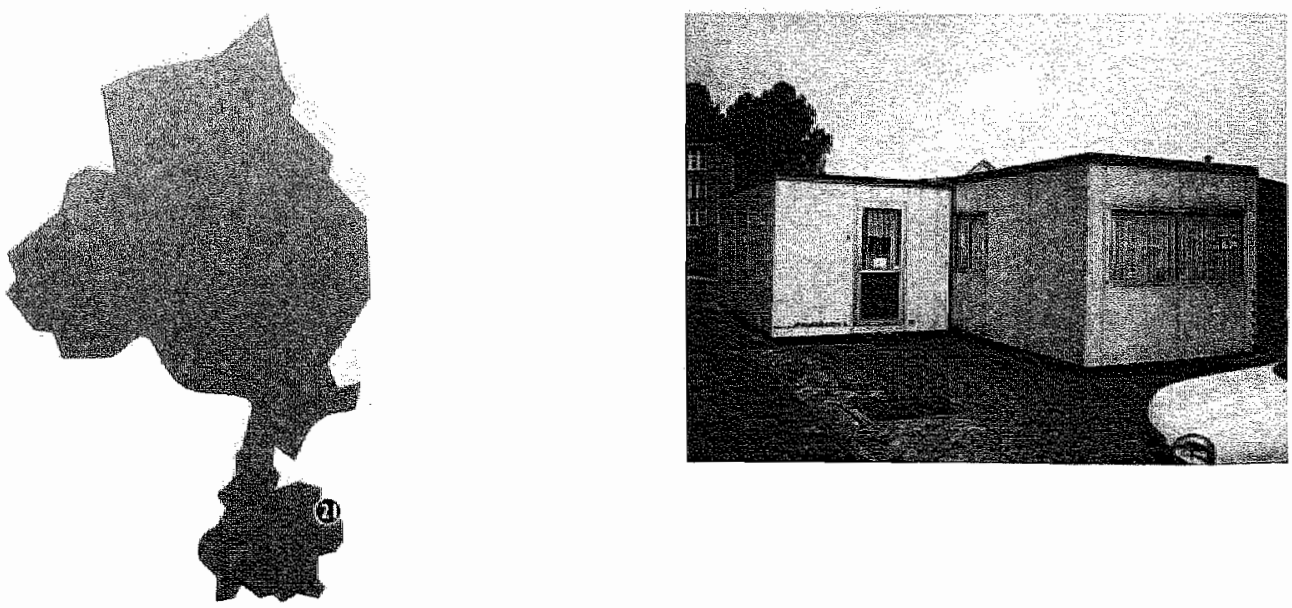
22. I Gerondheldseenumim 10. van kleef

Drvan Kleefstraat 27,6217 JJ Maastricht

\section{Gezondheidscentrum}

\section{Fruisartsen}

Castermans GAHM

Stalenhoef PA

Huymen LGJ

Maaskant M

Schille B

\section{Dokterassistent( $\mathrm{e})(\mathrm{n})$}

Haurvast R

Gilissen-van Laar L

Mawhin B

\section{Financieringswijze}

Aanstellingen bij RL

\section{Financieringsbron}

Vernieuwingsfonds

Samenwerkingsomvang 0.9 Fte
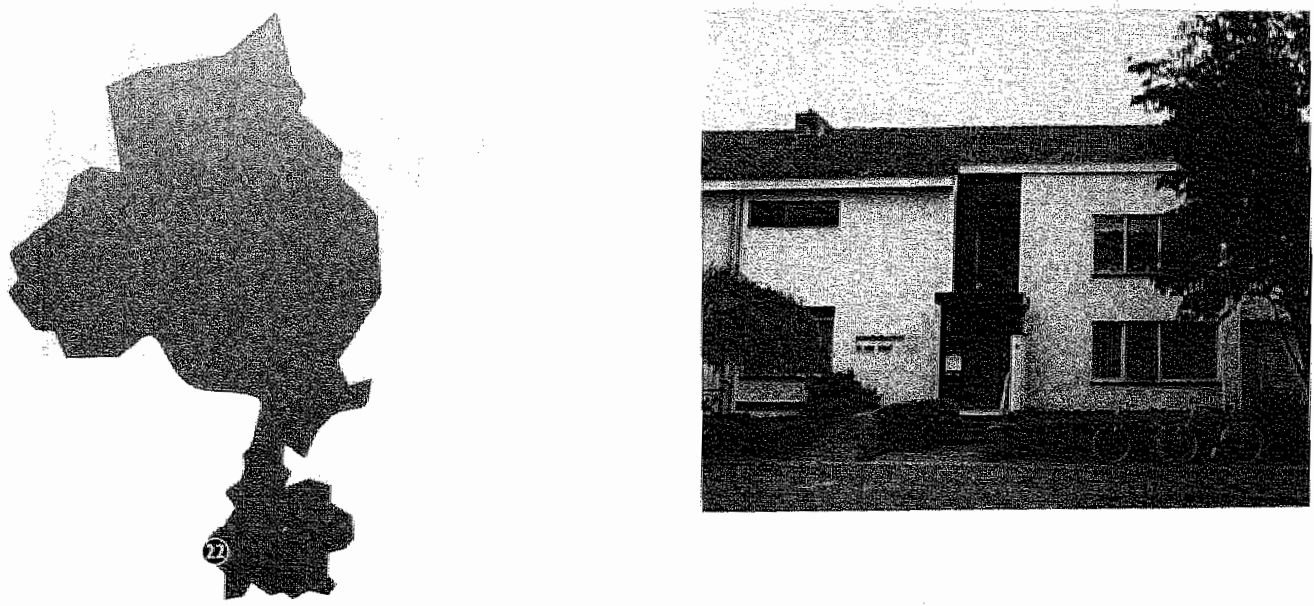
23. I Minsartspralkthk soomers

Kapelweg 54, 6466 AV Kerkrade

\section{Groepspraktijk}

Huisartsen

Soomers-Turlings JMSJG

Soomers FLM

Stoffers HEJ

\section{Dokterassistent(e)(n)}

Krol-Paffen PTE

Cabri SW

\section{Financieringsbron}

Vernieuwingsfonds

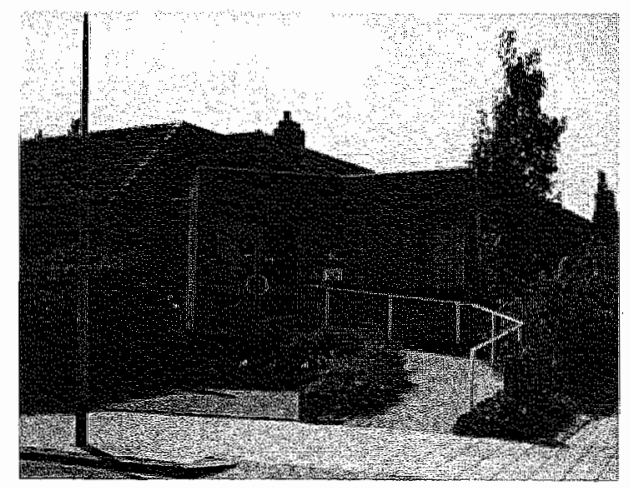

Samenwerkingsomvang 0.55 Fte

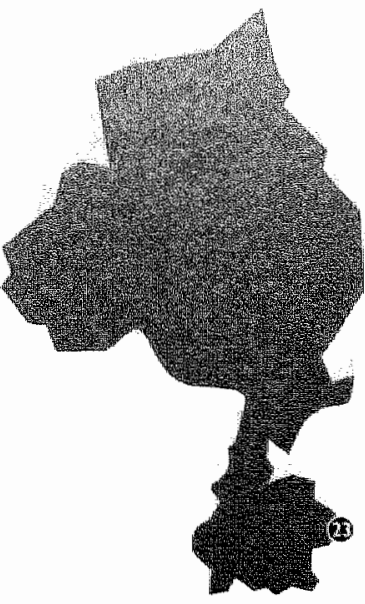


24. IV Hulsarispralitill vain Dongea

16.

Pastoor Jeukenstratat 6,5966 NM America

\section{Solo-praktijk}

\section{Huisartsen}

Dongen van JJAM

\section{Dokterassistent(e)(n)}

Wijers CJF

\section{Financieringsbron}

Vernieuwingsfonds

Aanstelling bij $\mathbb{R L}$

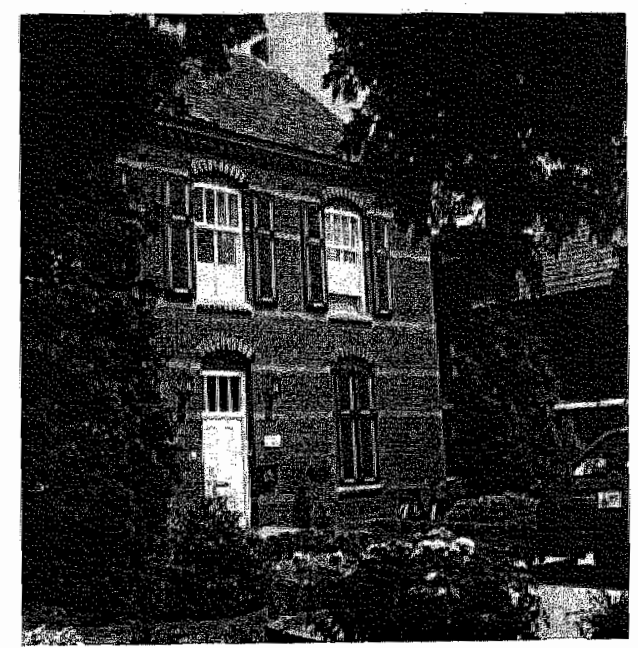

Samenwerkingsomvang 0.1 Fte

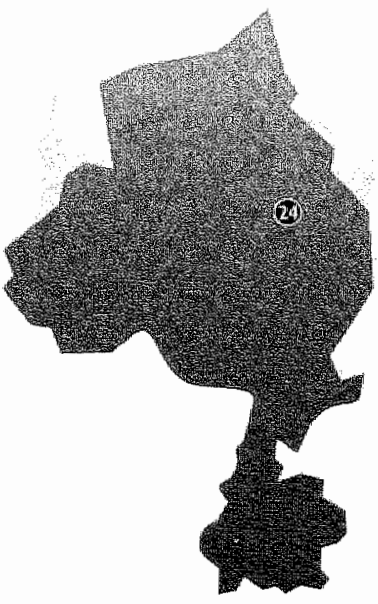


St.Rochusstraat 13, 6466 LKK Kerkrade

\section{Solo-praktijk}

\section{Huisartsen}

Ploeg van der JEMCl.

\section{Dokterassistent(e)(n)}

Stijntjes-van der Ploeg HM

Papousek-Stevens DAM

\section{Financieringsbron}

Vernieuwingsfonds

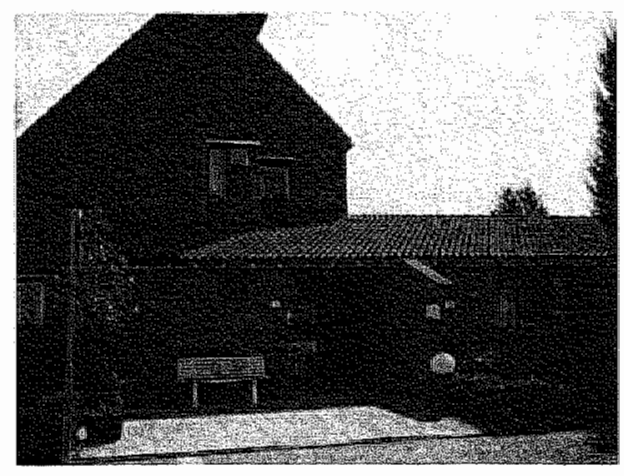

Samenwerkingsomvang $0.1 \mathrm{Fte}$

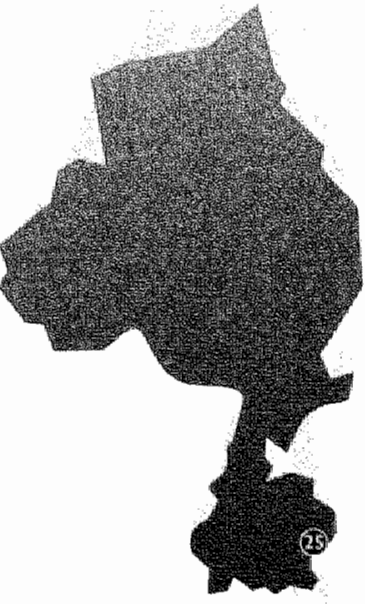


Kommerstraat 51, 6351 ES Bocholtz

\section{Groepspraktijk}

\section{Huisartsen}

Mom EMA

Schepers PHM

\section{Dokterassistent(e)(n)}

Vliex $\mathbb{B}$

Hofman "T

Kleyne A

\section{Financieringsbron}

Vernieuwingsfonds

Aanstelling bij RL

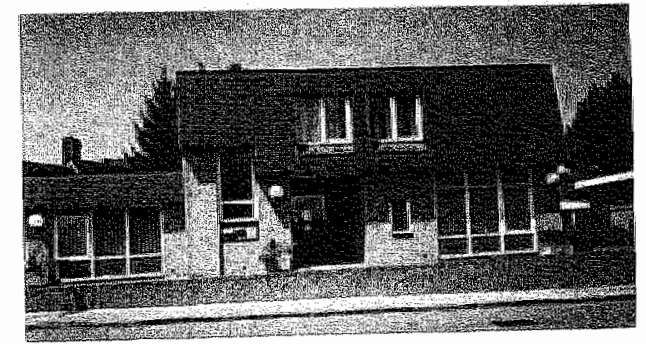

Samenwerkingsomvang 0.2 Fte

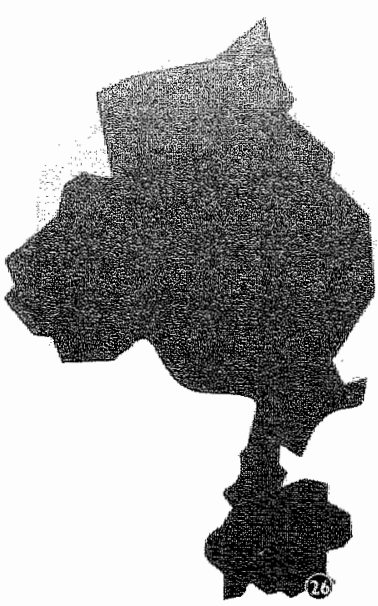


27. I Hulsartspraktigk Baatlo

Kwistbeeklaan 3,5991 XH Baarlo

\section{Groepspraktijk}

\section{Huisartsen}

Hoefnagels JH

Stemkens GWM

Heeswijk van AlM

\section{Dokterassistent(e)(n)}

Heeswijk van-Janson $\mathbb{N}$

Korsten-Smeets L

Wijnen $\mathrm{A}$

\section{Financieringswijze}

Aanstelling bij RL

\section{Financieringsbron}

Vernieuwingsfonds

Samenwerkingsomvang 0.1 Fte
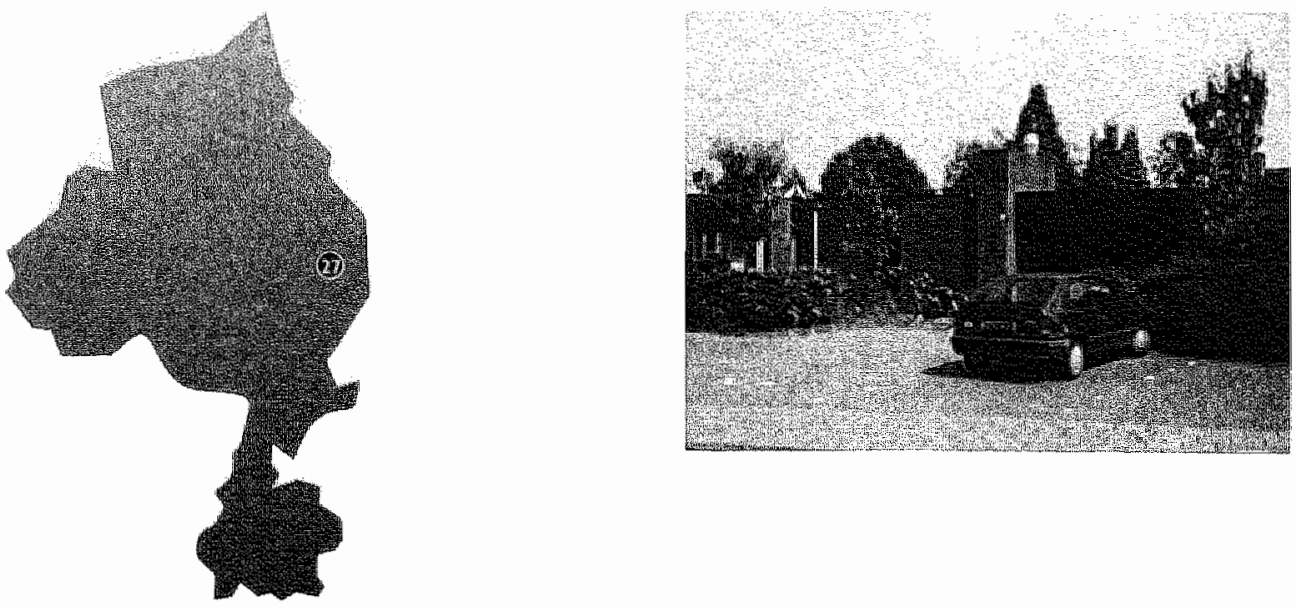
28. 1. Huisartspraktilk Smeets

Burg.van den Broekstraat 15, 6081 AP Haelen

\section{Solo-praktijk}

\section{Huisartsen}

Smeets FGB

\section{Dokterassistent(e)(n)}

Janssens ML

\section{Financieringsbron}

Vernieuwingsfonds

Aanstelling bij RL

Samenwerkingsomvang 0.1 Fte
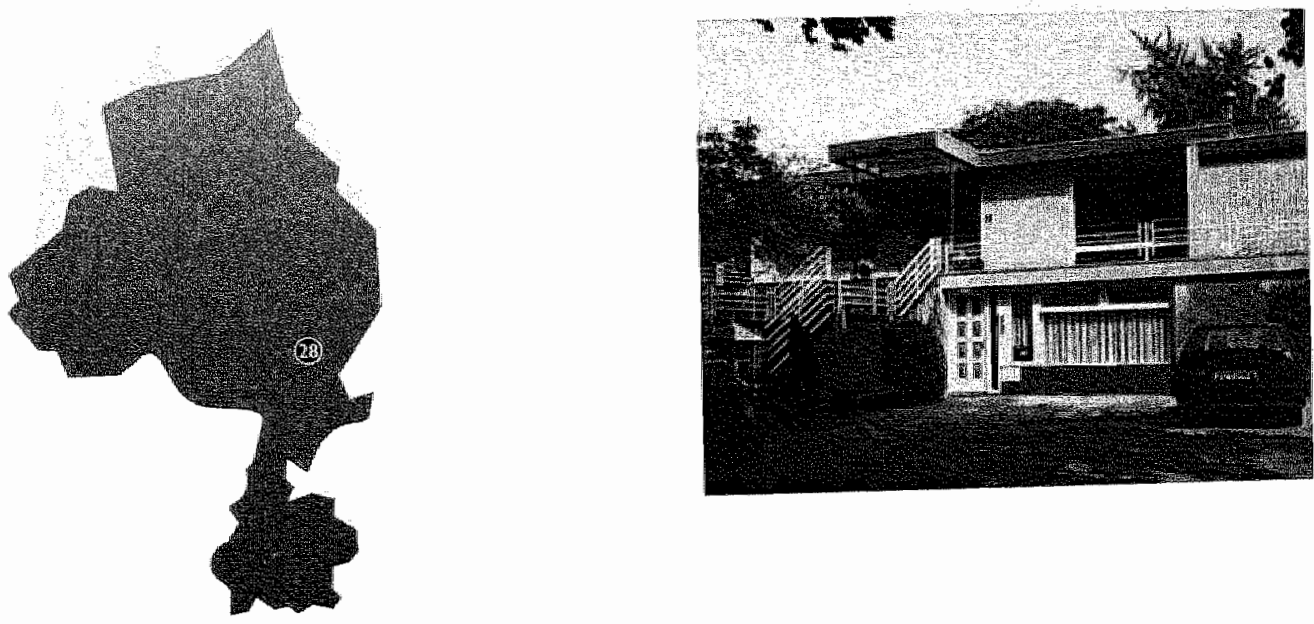
Sterrebos 48,5344 AR Oss

\section{Gezondheidscentrum}

\author{
Huisartsen \\ Rasing A \\ Maas S \\ Becht $M$
}

\section{Dokterassistent(e)(n)}

Wel van J.

Veltmeijer W.

Heiinsbergen van $M$.

\section{Financieringswijze}

Geld

\section{Financieringsbron}

Stimuleringsregeling UHP

Samenwerkingsomvang 0.1 Fte
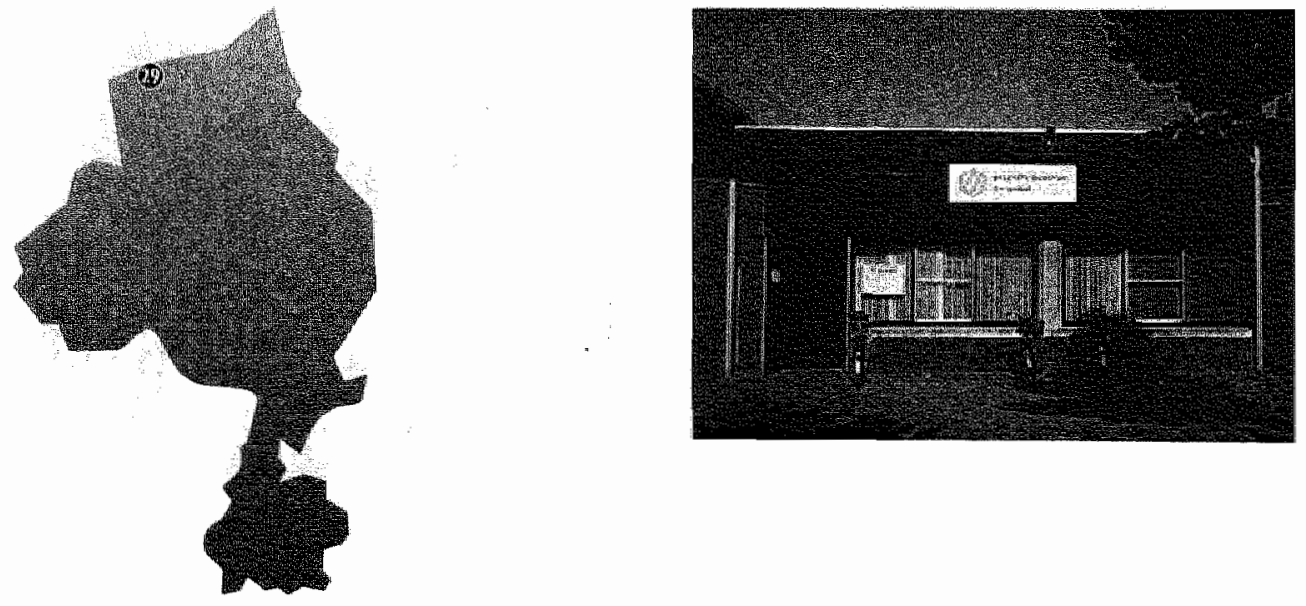
30 1: Huisartsprakkilk Vaessen-Soeters

trty

Dorpstraat 5, 6444 AK Brunssum

Groepspraktijk

\section{Huisartsen}

Vaessen MHJ.

Soeters I.

\section{Dokterassistent(e)(n)}

Janssen $G$.

Huntjens MAM.

\section{Financieringsbron}

Stimuleringsregeling UHP

Geld

Samenwerkingsomwang 0.2 Fte
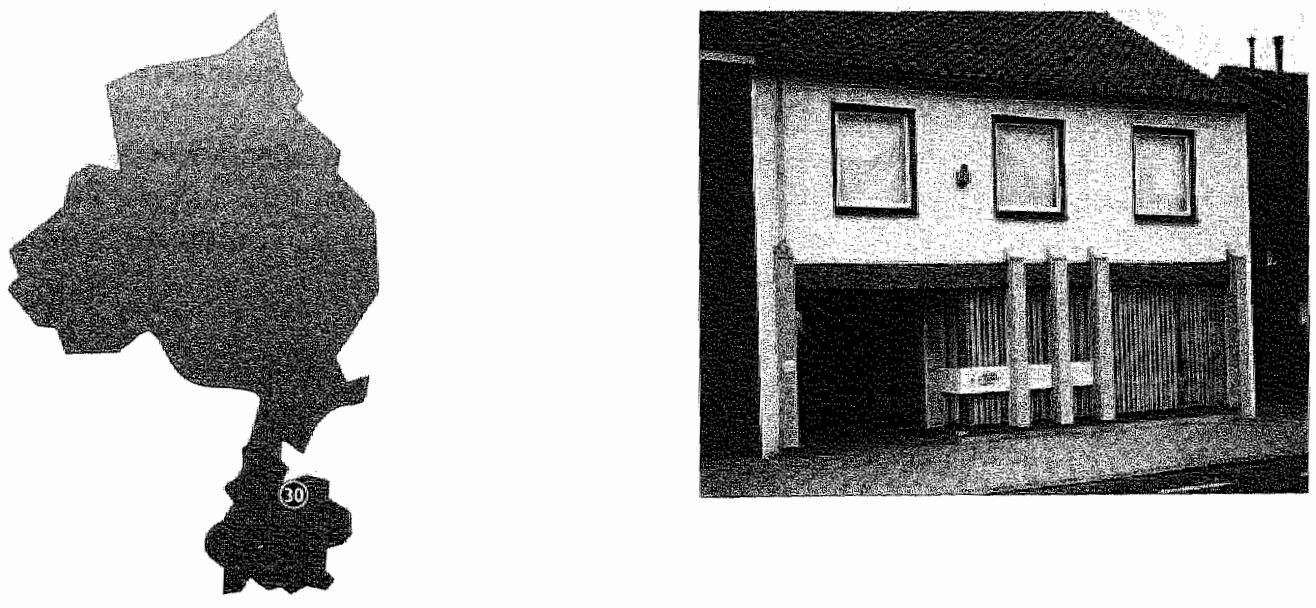


\section{CONTRACTVORMEN ACADEMISERING} HUISARTSGENEESKUNDE (HAM)

\section{Contract bij aanwezigheid van een RL-arts}

Onderstaand contract beschriff de sithatie in een netwerk-praktijk, alwaar een buisantsmedewerker full-time wordt gederacheerd. Deze zogenaamde RL-arts participeent zowel aan de taken op bet gebied van de patiëntenzorg, als op bet gebied tan onderwijs en onderzoek.

\section{Modelcontract 1}

De Rijksuniversiteit Limburg, gevestigd te Maastricht, vertegenwoordigd door voorzitter en secretaris van haar College van Bestuur, hierna te noemen de universiteit

en

huisarts(en) te

, hierna te noemen de praktiik

zijn overeengekomen

\section{Artikel 1.}

In deze overeenkomst wordt verstaan onder:

de faculteit: de Faculteit der Geneeskunde van de universiteit, het faculteitsbestuur: het bestuur van de Faculteit der Geneeskunde, de vakgroep: de universiteit: de vakgroep huisartsgeneeskunde van de Faculteit der Geneeskunde. de Rijksuniversiteit Limburg

\section{Artikel 2.}

1

De praktijk stelt haar gezondheidscentrum open onder hierna te beschrijven voorwaarden voor bepaalde activiteiten van de universiteit op het gebied van wetenschappelijk onderwijs, wetenschappelijk onderzoek en gezondheidszorgontwikkeling, voorzover volgens de praktijk de belangen van patiènten zulks toelaten en voorzover niet strijdig met de doelstellingen, statuten en huishoudelijk reglement van de praktijk en haar samenwerkingsovereenkomst met het ziekenfonds 


\section{Artikel 3.}

1

De praktijk stelt jaarliks in overleg met het bestuur van de vakgroep en met inachtneming wan deze overeenkomst een werkplan op, warin opgenomen worden:

- de aard en omvang van de verschillende taken op het gebied van wetenschappelijk onderwijs, onderzoek, registratie en gezondheidszorgontwikkeling die binnen de praktijk zullen worden uitgevoerd in het kalenderjaar waarop het plan betrekking heeft.

- concrete afspraken over de wijze warop deze taken worden witgevoend.

\section{2}

Het werkplan beschrijft de verdeling wan de werkzaamheden over de praktijk-huisartsen en de RL-huisarts (en bevat tevens een vermelding van de werkzaamheden van de overige teamleden zoals gedefinieerd in het Huishoudelijk Reglement van de praktijk, voorzover relevant voor de in lid I genoemde raken).

\section{3}

Het werkplan en eventuele wijzigingen daarwan behoeven de goedkeuring van het faculteitsbestuur.

\section{Artikel 4.}

1

De universiteit zal aan de praktijk de kosten vergoeden die binnen de praktijk ontstaan als gevolg van het uitvoeren van onderzoek- en onderwijsactiviteiten. Hierbij word met name gedacht aan:

- huisvestingskosten (energie en water, onderhoud, schoonmaakkosten),

- bureau en huishoudelijke kosten (kantoormiddelen, drukwerk, telefoonkosten, porti, huishoudelijke uitgaven),

- extra personeelsinzet t.b.v. secretariee/administratieve ondersteuning,

* reis-en verblijfkosten van de RL-huisarts en de andere huisartsen.

2

De praktik ontvangt per kalenderjat een lump-sum bedrag van Fl. 22.000, $=$ per fulltime equivallent samenwerking exclusief de Fte's samenhangende met de werkzaamheden ten behoeve van het Registratienet Huisartspraktijen.

3

De betaling van de lump-sum vergoeding vindt plaats in januari van elk kalenderjaar. 4

Voor de bijdragen aan het Registratienet Huisartspraktijken wordt door de universiteit een vergoeding gegeven conform de nieuwe financieringsregeling RNH. Deze regeling mak integraal deel uit van deze overeenkomst..

\section{5}

De praktijk zal vốr 1 juli van enig jaar een afschrift van haar jaarrekening betreffende het voorafgaande jaar aan de universiteit ter beschikking stellen. In de kostenspecificatie van de jarrekening dienen de in lid 1 genoemde kostenvergoedingen opgenomen te zijn. 


\section{Artikel 5.}

1 .

Alvorens de praktijk vanwege de onderwijs-en onderzoek activiteiten investeringen in bouw, verbouw, inrichting en/of inventaris zal doen, treden praktijk en universiteit hierover in overleg. Dit overleg dient tot overeenstemming te leiden over de noodzaak en de omvang van de investering, alsmede over de hoogte van de jaarlijkse bijdrage, die de universiteit inzake rente en aflossing op deze investering zal betalen, en tenslotte over de garantie die de universiteit zal moeten geven om de financiering van de investering mogelijk te maken.

Tevens zullen daabij afspraken worden gemaakt over de wijze van betaling van deze kosten, terwijl ook de wederzijse verplichtingen, voortvoeiend uit deze investeringen na het moment van expiratie van deze overeenkomst worden vastgelegd.

\section{Artikel 6.}

1

Indien een der praktijk-artsen besluit zijn dienstverband bij de praktijk te bezindigen zal de opvulling van de ontstane vacature door de praktijk geschieden na overleg met de universiteit.

\section{Artikel 7.}

Bij geschillen tussen de universiteit en de praktijk, word een geschilencommissie benoemd. Het faculteitsbestuur en de praktik wijzen ieder afzonderlik een lid aan. Beide aldus benoemde leden wijzen in overleg een derde hidtevens voorzitter aan, die de hoedanigheid van meester in de rechten moet bezitten. De geschillencommissie oordeelt naar redelijkheid en billijkheid. De uitspraak is bindend.

\section{Artikel 8.}

1

Deze overeenkomst treedt in werking op

\section{2.}

Indien deze owereenkomst niet per

door éen der partijen is beèindigd wordt haar werkingsduur woor onbepaalde tijd ver lengd. Beẻindiging van deze overeenkomst dient te geschieden met een opzegtermijn van 1 jaar.

In afwijking van het hiervoor bepaalde eindigt deze overeenkomst in ieder geval op het moment dat de samenwerking tussen de praktijk en het ziekenfonds 
of haar rechtsopvolger eindigt, en indien dit naar de mening van (het bestuur van) de praktijk betekent dat de financiering van de praktijk niet langer gewaarborgd is.

4

Na beëindiging van de samenwerking onder deze overeenkomst blijven de artikelen 4, 7 en 8 van kracht woorzover zij dan nog van belang zijn.

5

Indien de overeenkomst wordt beëindigd vervallen ook de aanstellingen wan de huisartsen bij de universiteit.

Namens het College van Bestuur

De praktijk (Stichting), van de Rijksuniversiteit Limburg, de directeur Faculteit der Geneeskunde, voor deze,

beheerder vakgroep huisartsgeneeskunde 


\section{Contract bij grootschalige samenwerking en terugfinanciering gezond- heildszorgdeel}

In sommige gevallen is besloten de buisantsen volledig in dienst te taten zijn zan de Rijksuniversiteit Limburg. De praktijk financiert bet aanstellingsteel, dat besteed wordt aan dagelijkse patiëntenzorg terug naar de universiteit.

\section{Modelcontract 2}

De Rijksuniversiteit Limburg, gevestigd te Maastricht, vertegenwoordigd door voorzitter en secretaris van haar College van Bestuur, hierna te noemen de universiteit

en

huisartsen te

hierna te noemen de praktijk

zijn overeengekomen

\section{Artikel 1}

In deze overeenkonst wordt verstaan onder:

de faculteit:

de Faculteit der Geneeskunde van de universiteit

het faculteitsbestuur: het bestuur van de Faculteit der Geneeskunde

de vakgroep:

de universiteit: de vakgroep huisartsgeneeskunde van de Faculteit der Geneeskunde de Rijlksuniversiteit Limburg

\section{Artikel 2}

1

De praktijk stelt zijn huisartspraktijk open onder hierna te beschrijven voorwarden voor bepaalde activiteiten van de universiteit op het gebied van wetenschappelijk onderwijs, wetenschappelijk onderzoek, registratie en gezondheidszorgontwikkeling, voorzover cle belangen wan patiènten zulks toelaten.

2

De praktijk zal worden uitgeoefend door

en

die allen bij de universiteit zijn aangesteld. 


\section{Artikel 3}

1

De praktijk stelt jaarlijks in overleg met her bestuur van de vakgroep en met inachtneming van deze overeenkomst een werkplan op, warin opgenomen worden:

- de aard en de omvang van de verschillende taken op het gebied van wetenschappelijk onderwijs, wetenschappelijk onderzoek, registratie en gezondheidszorg-ontwikkeling die binnen de praktik zullen worden uitgevoerd in het kalenderjaar waarop het plan betrekking heeft.

- concrete afspraken over de wijze waarop deze taken worden uitgevoerd.

2

Het werkplan beschrift de verdeling van de werkzambeden over de huisartsen, en bewat tevens een vermelding van werkzaamheden van andere eerstelijnswerkers, voorzover relevant voor de in lid 1 genoemde taken.

3

Het werkplan en eventuele wijzigingen daarvan behoeven de goedkeuring van het bestuur van de vakgroep.

4

Indien het aantal ingeschreven patiènten en/of de LHV-normpraktijkomvang dusdanig zijn gewijzigd dat het voor de gewone gezondheidszorg benodigde equivalent huisarts meer dan $10 \%$ afwijkt van het mu vastgestelde equivalent, zal dit voor de rest van de looptijd van deze overeenkomst worden bijgesteld.

5

Eenmaal per jaar stelt de praktijk in overleg met de vakgroep een evaluatie op van de in het kader van het werkplan uitgevoerde werkzaamheden. Deze evaluatie wordt voor 1 april van het daaropvolgende jaar aan het bestuur van de vakgroep voorgelegd.

\section{Artikel 4}

1

De universiteit zal aan de huisarts de kosten vergoeden die binnen de praktijk ontstaan als gevolg van het witvoeren wan onderzoek-, onderwijs-, registratie- en gezondheids-zorgontwikkelingsactiviteiten. Hierbij wordt met name gedacht aan:

- huisvestingskosten (energie en water, onderhoud, schoonmakkosten).

- bureau en huishoudelijke kosten (kantoormiddelen, drukwerk, telefoonkosten, porti, huishoudelijke uirgaven).

- reis- en verbliffosten betrekking hebbend op de relatie van de huisarts met de universiteit.

- extra personeelsinzet t.b.v. secretarieel/administratieve ondersteuning.

2

De praktijk ontvangt per kalenderjar een lump-sum bedrag van Fl. 22.000,= per fulltime equivalent samenwerking exclusief de Fte's samenhangende met de werkzaamheden ten behoeve van het Registratienet Huisartspraktijken.

De betalling van de lump-sum vergoeding vindt plaats in januari van elk kalenderjaar. 
Voor de bijdragen aan het Registratienet Huisartspraktijken wondt door de universiteit een vergoeding gegeven conform de nieuwe financieringsregeling RNH. Deze regeling maakt integraal deel uit van deze overeenkomst.

\section{5}

De praktijk zal vóor 1. juli van enig jaar een afschrift van haar jaarrekening betreffende het voorafgaande jaar aan de universiteit ter beschikking stellen. In de kostenspecificatie van de jaarrekening dienen de in lid 1 genoemde kostenvergoedingen opgenomen te zijn.

\section{Artikel 5}

1

De huisartsen zijn allen bij de universiteit angesteld.

voor. Fite

\section{2}

De praktijk betaalt aan de universiteit, na declaratie door de universiteit, het gezondheidszorgdeel teng. Dit betreft ..... Fte salarislasten (werkgeverslasten + opslagen ABP, vakantiegeld en de universitaine opslag voor financiele en personele diensiverlening). Het exacte bedrag wordt jaarlijks vastgesteld en als bijlage bij het werkplan opgenomen.

3

De universiteit declareent per liwartaal achteraf.

4

Beëindiging van het contract door de praktijk leidt automatisch tot onmidclellijke beëindiging van de anstellingen van de huisartsen bij de universiteit.

\section{Artikel 6}

1

Indien het dienstverband van éen van de huisartsen bij de universiteit eindigt treden de universiteit en de huisarts in overleg over de te nemen acties. Een eventuele nicuwe huisarts wordt door de universiteit en de praktijk gezamenlijk geworven.

\section{2}

Indien op grond van het algemeen rijksambtenarenreglement het dienstwerband van én van de huisartsen bij de universiteit vanwege de universiteit wordt bedindigd, treden uniwersiteit en de praktijk in overleg ower de wijze waarop de werkzaamheden worden uitgevoerd tot het moment dat opvolging van de huisarts is geregeld.

\section{Artikel 7}

Bif geschillen tussen de universiteit en de praktijk, wordt een geschillencommissie 
benoemd. Het bestuur van de vakgroep en de praktijk wijzen ieder afzonderlijk een lid aan. Beide aldus benoemde leden wijzen in overleg een derde lid tevens een voorzitter aan, die de hoedanigheid van meester in de rechten moet bezitten. De geschillencommissie oordeelt naar redelijkheid en billijkheid. De uitspraak is bindend.

\section{Artikel 8}

1

Deze overeenkomst treedt in werking op

en wordt aangegaan voor onbeperkte duur.

2

Beëindiging van deze overeenkomst dient te geschieden met een opzegtermijn van $\mathbb{1}$ jaar.

3

Bij langdurige ziekte of overlijden van één van de huisartsen treden praktijk en voorzitter van de wakgroep in overleg om te bezien op welke wiize het werkplan kan worden uitgevoerd.

4

Deze overeenkomst wordt geacht met onmiddellijke ingang te zijn beëindigd bij onder curatele stelling of faillissement van de praktijk.

5

Bij niet nakomen van de, in het werkplan opgenomen, verplichtingen door de praktijk, ter beoordeling van een samen te stellen geschillencommissie, kan de universiteit het contract opzeggen met inachtneming wan een opzegtermijn van 3 maanden.

Námens her College van Bestuur De praktijk (Stichting), van de Rijksuniversiteit Limburg, de directeur Faculteit der Geneeskunde, voor deze,

beheerder vakgroep huisartsgeneeskunde 


\section{Contract bij kleinschalige samenwerking}

Dit type contract wordt doorgaans gebmikt indien er sprake is van een samenwerking voor minder dan 0.4 Fie, waarbij de participanten doorgaans deelnemen aan werkzaambedien op bet gebied van onderurifs of onderzoek of registratie.

\section{Modelcontract 3}

De Rijksuniversiteit Limburg, gevestigd te Maastricht, vertegenwoordigd door voorzitter en secretaris van haar College van Bestuur, hierna te noemen de universiteit

en

, huisartsen te

hierna te noemen de praktijk

zijn overeengekomen

\section{Artikel 1}

In deze overeenkomst wordt verstaan onder:

de faculteil: de Faculteit der Geneeskunde van de universiteit

het faculteitsbestuur: het bestuur van de Faculteit der Geneeskunde

de vakgroep: de valkgroep huisartsgeneeskunde van de Faculteit der Geneeskunde

de universiteit: de Rijksuniversiteit Limburg

\section{Artikel 2}

De praktijk stelt zijn huisartspraktijk open onder hierna te beschrijven voorwaarden voor bepaalde activiteiten van de universiteit op het gebied van wetenschappelijk onderwijs of wetenschappelijk onderzoek of registratie, voorzover de belangen van patiënten zulks toelaten.

\section{Artikel 3}

1

De praktijk stelt jaarijiks in overleg met het bestuur van de vakgroep en met inachtneming van deze overeenkomst een werkplan op, waarin opgenomen worden:

- de aard en de omvang van de verschillende taken op het gebied van wetenschappelijk onderwijs of wetenschappelijk onderzoek of registratie, die binnen de praktijk zullen worden uitgevoerd in het kalenderjaar waarop het plan betrekking heeft.

- concrete afspraken over de wijze waarop deze taken worden uitgevoerd.

2

Het werkplan beschrijft de verdeling van de werkzaamheden over de huisartsen, en bevat tevens een vermelding van werkzaamheden van andere eerstelijnswerkers, voorzover relevant voor de in lid 1 genoemde taken. 
Het werkplan en eventuele wijzigingen daarvan behoeven de goedkeuring van het bestuur van de vakgroep.

\section{Artikel 4}

1

De huisarts(en) word(t)(en) worden voor de uitwoering van de in artikel 1 genoemde activiteit bij de universiteit aangesteld voor in totaal. (toegevoegd docent of toegevoegd onderzoeker). Fte in de rang van 2

Onverminderd de vergoeding welke gepaard gaat met de aanstelling van de huisarts bij de universiteit zal de universiteit jaarlijks een bedrag van FI................. vergoeden voor de kosten die binnen de praktijk ontstaan als gevolg van het uitvoeren van de in het werkplan gedefinieerde taak.

3

Het bedrag zal aan de huisarts jaarlijks worden uitgekeerd aan het begin van het kalenderjaar.

\section{Artikel 5}

Bij geschillen tussen de universiteit en de praktijk, wordt een geschillencommissie benoemd. Het bestuur van de vakgroep en de praktijk wijzen ieder afzonderlijk een lid aan. Beide aldus benoemde leden wijzen in overleg een derde lid tevens een voorzitter aan, die de hoedanigheid van meester in de rechten moet bezitten. De geschillencommissie oordeelt naar redelijkheid en billijkheid. De uitspraak is bindend.

\section{Artikel 6}

Deze overeenkomst treedt in werking op

en wordt, indien niet voortijdig beëindigd, gecontinueerd voor onbepaalde tijd. Ieder der partijen kan de overeenkomst tussentijds beëindigen met inachtneming van een opzegtermijn van 3 maanden. In geval van praktijkbeëindiging, onder curatele stelling of Paillissement van de praktijk heeft ieder der partijen het recht om deze overeenkomst met onmiddellijke ingang te beëindigen.

Namens het College van Bestuur De praktijk (Stichting), Van de Rijksuniversiteit Limburg, de directeur Faculteit der Geneeskunde, voor deze,

beheerder vakgroep huisartsgeneeskunde 


\section{APPENDIX C}

\section{WERKPLAN HAM 1994}

\section{Werkplan academisering 1994}

Naam praktijk:

Soort praktijk:

Adres:

Postcode en plaats:

Telefoon praktijk:

Periode waarover: 1 januari 1994 tot en met 31 december 1994

Inzet in fre's: 1.1 Fte

In aanstellingsvorm:

$0.0 \mathrm{Fte}$

In toegevoegde menskracht:

0.8 Fte

In geld:

Fl. 0.00

Output-financiering:

0.3 Fte

Exploitatievergoeding: $\quad$ Fl. 11,000 $=$

Onderwijs:

2 PMOH-studenten

2 studenten adoptiemodel

6 studenten OEL

0.10 Fte

Onderzoek:

Participatie an project

Participatie aan project

Uitwerken vraagstelling tot subsidieaanvraag

Registratienet Huisartspraktijken (RNH) :

Basale registratietaken 
Opmerkingen:

Ondertekend dd.

Namens de RL, Namens de praktijk, 


\section{APPENDIX D \\ CENTRALE COÖRDINATIE VAN \\ ONDERWIJS EN ONDERZOEK}

\section{Inleiding}

Huisartsen zijn een interessante doelgroep voor diverse universitaire vakgroepen. Ze worden dan ook regelmatig gevraagd hun medewerking te verlenen aan met name research-projecten. Dit komt vooral vanwege de generalistische benadening (alle patiëntencategorieën zijn er te vinden) van de huisartsgeneeskunde en de mogelijkheid om direct toegang te krijgen tot de patiëntenpopulatie.

Het is dan ook niet vreemd dat diezelfde huisartsen zeer regelmatig benderd worden door zowel de universiteit als de industrie. Deze ongecoördineerde benadering leverde aan de Rijksuniversiteit Limburg zoveel negatieve reacties van huisartsen op, dat in het begin van de tachtiger jaren nagedacht werd over de oplossing van dit probleem. Oorspronkelijk werd gedacht dat een centraal coördinatiepunt, gesteund door zowel het Academisch Ziekenhuis, de Rijksuniversiteit Limburg als de Districts Huisartsvereniging een oplossing zou kunnen bieden. De gedachten hierover werden vastgelegd in een nota BEL (Bureau Eerste Lijn). Vele discussies werden aan deze op zich interessante nota gewijd, echter niet met het gewenste effect. Met name de financiële ondersteuning vanuit de drie participerende instanties bleek een onoverkomenlijke barriere, hetgeen de discussies uiteindielijk helaas heeft doen verstommen.

De Faculteil der Geneeskunde bleef echter aandacht hebben voor dit probleen en besloot in 1988 tot de oprichting van een Coördinatiebureau Eerste Lijn (CEL).

De centrale doelstelling van het CEL betrof de coördinatie van alle onderwijs- en onderzoekprojecten, die met behulp van perifere ecrstelijnswerkers (voormamelijk huisartsen) zouden moeten worden uitgevoerd. Aangezien het CFL werd geinitieerd vanuit de geneeskundige faculteit bleek al snel dat het primair zou gaan om projecten van en met huisartsen in de universitaire regio (Limburg en Zuid-Oost-Brabant).

\section{Organisatorische plaats van het CEL}

Om onafhankelijkheid te waarborgen werd het CEL gepositioneerd op een centralle en neutrale positie in de facultaire organisatie. Hiervoor werd het Faculteitsbureau gekozen. Een begeleidingscommissie bestande uit de decaan van de faculteit, een huisarts namens het bestuur van de Districts Huisartsvereniging en drie hoogleraren op het terrein van extramuraal onderzoek en onderwijs hield toezicht op het werk van het coördinatiebureau.

De primaire gebruikers van het CEL waren uiteraard de facullaire vakgroepen en de onderzoeksthemata. Om echter optimale coördinatie te realiseren werden ook de zieken huisafdelingen van het Academisch Ziekenhuis Maastricht (AZM) en externe onderzoekers (ook vanuit industriële organisaties) toegellaten tot de dienstverlening van het CEl. 
Helaas werd door de industrie de weg naar het CEL niet gevonden, enerzijds omdat men zelf directe lijnen tot de huisartsen heeft gerealiseerd en anderzijs omdat men zich niet wil laten leiden door de algemene uitgangspunten dit bureau.

\section{Bekendmaking van het CEL}

In 1988 werden alle onderzoekers en docenten via een folder op de hoogte gesteld van het bestaan van het CEL en de wijze warop aan de dienstverlening gestalte zou worden gegeven. Aan de diverse programmaleiders en medewerkers werd tevens om suggesties gevraagd.

Ook de regionale huisatsen en het bestuur van de Districts Huisartsenvereniging werden uitgebreid geinformeerd. Aan deze bekendmaking werd een enquête gekoppeld, warin de huisartsen gewragd werd naar hun belangstelling op het gebied van (universitali) onderwijs en onderzoek. Deze enquête zou dienst kunnen doen bij de toekomstige wervingscampagnes en moeten leiden tot een optimale spreiding van de projecten over de huisartspopulatie. In het meest ideale model zou de integrale benaderingssystematiek op termijn vervangen kunnen worden door een gestratificeerde (gedifferentieerde) benadering van huisartsen per project.

De reacties waren zonder meer positief en al snel klopten de eerste onderzoekers aan bil her CEL.

Na de eerste bekendmaking via bovengenoemde folders werd periodiek een CELnieuwsbrief uitgegeven. In deze nieuwsbrief werden nieuwe projecten beschreven en werd de voortgang van reeds lopende projecten aan de huisartsen en de universitaire gemeenschap bekend gemaakt. De werving van projecten geschiedde derhalve altijd in eerste instantie schriftelijk via deze nieuwsbrief. De projectverantwoordelijke leverde de hoofdbestanddelen voor de tekst aan waarna de coördinator van het CEL de eindredaktie verzorgde. De projectbeschrijvingen in de CEL-nieuwsbrief moesten in ieder geval bevatten:

- korte, maar voor de huisats heldere, beschrijving van het project in termen van doelstelling, opzet en duur;

- concrete vraag aan de huisarts, met gegevens over de verwachte belasting van de huisarts, dienst assistent(e) en de patiënten;

- informatie over de wijze waarop de huisarts in de loop van het project en na afloop zouden worden geinformeerd;

- informatie over de wijze waarop de inspanningen van betrokkenen (luisarts, assistent, patiénten) zouden worden vergoed.

Het CEL, profileercle zich verder door de organisatie van bijeenkomsten, congressen en symposia voor huisartsen, zowel lokaal, nationaal als internationaal.

Tenslotte werden zowel de huisartsen als de facultaire medewerkers geïformeerd over het werk van het CEL door middel van uitgebreide jaarverslagen. 


\section{De wervingsprocedure van het CEL}

Na een eerste telefonisch contact van de geinteresseerde (onderzoeker, docent, huisarts) wordt een persoonlijk onderhoud geïnitieerd bij het Coördinatiebureau Eerste Lijn. Tijdens dit gesprek, dat idealiter in een vroegtijdig stadium plaatsvindt, wordt stilgestaan bij de doelstelling, de beschrijving en de organisatorische opzet van het project en bij de concrete vraag die aan het CEI gesteld wordt. Het CEL beoordeelt de organisatorische aspecten in relatie tot de mogelijkheden van het thuisartsgeneeskundige veld. Alvorens de daadwerkelijke wervingsaktie te beginnen, wordt de onderzoeker/docent uitgenodigd in de researchgroep respectievelijk onderwijsgroep van de vakgroep huisartsgeneeskunde. Op deze plaats worden inhoudelijke en methodologische aspecten nader bediscussieerd. Soms leidt dit tot aanpassingen van het project-protocol. Na de bespreking in de research- of onderwijsgroep worden afspraken gemaakt over de daadwerkelijk bekendmakings- en wervingsprocedure. In zijn algemeenheid wordt gekozen woor een werving via de reeds genoemde CEL-nieuwsbrief. Op deze wijze kunnen alle regionale huisartsen kennis nemen van het project en een eventuele interesse schriftelijk (via een invulstrook) aan het CEL bekendmaken. Pas daarna kan de onderzoeker/docent rechtstreeks contact opnemen met de geinteresseerde huisartsen en vervolgafspraken maken.

Mocht de belangstelling na deze eerste fase te gering zijn, dan wordt in overleg mer de verantwoordelijke onderzoeker/docent een verwolgstrategie bepaald, die kan bestaan uit een schriftelijke reminder of een meer gerichte telefonische zoekactie. Gebleken is dat een vervolgstrategie doorgaans niet nodig is.

\section{Overzicht projecten, symposia en dergelijke}

In de periode van 1 juni 1988 tot 1 januari 1992 zijn in totaal 65 onderzoeksprojecten bij het CEL aangemeld en conform de procedure afgehandeld. Daarnaast is op meer permanente basis gewerkt aan de werving wan huisartsen ten behoeve van onderwijsprojecten. Overigens moet gezegd worden dat van oudsher de coördinatoren van deze onderwijsprojecten grote bekendheid hadden met de wijze watrop zij huisartsen zouden moeten benaderen. Hun aandeel in de procedure is dan ook groot gebleven. Het CEL is hierbij dan ook meer op afstand faciliterend. De onderzoeksprojecten werden aangemeld vanuit diverse vakgroepen van de Rijksuniversiteit, vanuit alclelingen van het Academisch Ziekenhuis en vanuit externe instanties. Een overzicht hiervan wordt in figuur D. I gegeven. 


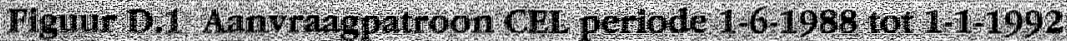

\begin{tabular}{|c|c|c|}
\hline $\begin{array}{l}\text { Naam van de vakgroep/afideling/instantie } \\
\text { Intern }\end{array}$ & $\begin{array}{l}\text { Absoluat } \\
n=65\end{array}$ & Relati \\
\hline Vakgroep hutsartggeneeskunde & 39 & $60 \%$ \\
\hline Vakgroep Interne Geineeskinde & 3 & $46 \%$ \\
\hline Vakgroep Medische Biologie & $\mathbb{1}$ & $1.5 \%$ \\
\hline Vakgroep Sociale Psychiatne & 2 & $3.1 \%$ \\
\hline Vakgroep Cardiologie & $\mathbb{1}$ & $1.5 \%$ \\
\hline Vakgnop GWO & 3 & $4.6 \%$ \\
\hline Vakgroep Medische Sociologie & 2 & $3.1 \%$ \\
\hline Vakgroep Onderabek van Onderwijs & 2 & $3.1 \%$ \\
\hline Vakgroep Neurologie & 1 & $1.5 \%$ \\
\hline Valkgroep Humane Biologie & 1 & $1.5 \%$ \\
\hline Vakgroep Epidemiologie & 2 & $3.1 \%$ \\
\hline Vakgroep Ninische Psychiatrie & 1 & $1.5 \%$ \\
\hline Medische Psychologte & 1 & $1.5 \%$ \\
\hline
\end{tabular}

\section{Aan RI. "gelleerde" instanties}

Diagniostisch Coördinerend Centrum (DCC-AZM)

2

$3.1 \%$

Instituut woor Geneesmiddelen, Veilligheid en Gedrag

1

$1.5 \%$

ExtemvTo-team Heuvelland

$1.5 \%$

CAD-Limburg

$11.5 \%$

Lucas-stichting

$1.5 \%$ 
Naast deze primaine dienstverlening van het CEL a an onderwijs en onderzoek, heeft het CEL zich in toenemende mate ook ontwikkeld als (mede-) organisator van lokale, nationale en internationale bijeenkomsten op huisartsgeneeskundig gebied.

In de periode van 1988 tot heden is medewerking verleend aan de volgende activiteiten:

\section{Internationale congressen:}

1

Spring-meeting van de European General Pracice Research Workshop (EOPRWw)

mei 1989 te Madrid

Registration Networks in General Practice

2

Autumn-meeting van de European General Practice Research Workshop (ECPRW) november 1989 te Birminghan

Referral studies

3

Spring-meeting van de European General Practice Research Workshop (ECPRW) mei 1990 ce Budapest

Doctor-patient relationship and qualitative research

住

Autumn-meeting van de European General Practice Research Workshop (EGPRW) november 1990 te Wenen

Quality assurance and quality assessment

5

Special meeting van de European General Practice Research Workshop (EGPRW) maart 1991 te Madrid

Future research in general practice in europe; main topics and main obstadles

6

Spring-meeting van de European General Practice Research Workshop (EGPRW)

mei 1991 te Porto

Collaborative studies

7

Autumn-meeting van de European General Practice Research Workshop (BGPTWW) Oktober 1991 te Varenna (ittaliè)

Drug prescription in General Practice

8

Spring-meeting van de European General Practice Research workshop (EGPRW)

april 1992 in Nottingham

Health Promotion in general practice

9

Autumn-meeting wan de European General Practice Research Workshop (EGPRWW) oktober 1992 te Leuven

Research in under-and postgraduate education in general practice 
Spring meeting wan de Eunopean General Practice Restarch Workshop (EGPRW) april 1993 te Zichron Yakov (Mrael)

Research in general practice on elderly people

11

Autumn-meding van de European General Practice Research Workshop (EGPRW) oktober 1993 te Parijs

Research in and management of chronic disseases

12

Spring-meeting wan de European General Practice Ressearch Workshop (EGPRW) mei 1994 te Kopenhagen (Denemarken)

The use of clinical standards and guidelines in general practice

13

Autumn-meeting van de European General Practice Research Workshop (EGPRW) okitober 1994 te Ljubliana (Slovenie)

Evaluation of costs-effectiveness (efficiency) in general practice

\section{Lokale en nationale activiteiten:}

\section{Randwijckcursussen}

In 1991:

Cholesterol nu

Kindergeneeskunde

Orthopeadie

Risico en risico-schatting

in 1992:

Enclocrinologie

Besliskunde voor de huisarts

Pijnbehandeling

Nieuwe cardiologische ontwikkelingen

In 1993:

Longziekten

Oncologie

Oogheelkinde

Geriatrie

In 1994:

Beeldvormende technieken

Nieuwe ontwikkelingen in de psychiatrie

Gastro-enterologie

Allergologie/Inmunologie 


\title{
Workshops Academisering 1988 t/m 1994
}

\author{
Congres "Deskundigheidsbevordering van de huisarts" \\ december 1988 te Maastricht
}

\author{
Congres "Ouderenzorg in Limburg" \\ december 1989 te Maastricht
}

Lustrumcongres 15-jarig bestaan van de Rijksuniversiteit Limburg

"De eerste lijn in Limburg; nu en straks"

oktober 1991 te Maastricht

Summercourse Werkgroep Onderzoek Kwaliteit (WOK) 1994

Symposium ter gelegenheid van het 5 -jarig bestaan van de interuniversitaire Werkgroep Onderzoek Kwaliteit (WOK)

1994

\section{Het CEL; van 1988 tot nu}

In 1988 werd de functie en de opzet van het CEL nader bestudeerd in her kader wan een afstudeerscriptie 1 . Reeds toen werd op basis van een uitgebreide studie de functie van het CEL positief bewonden zowel door de huisartsen als door de onderzoekers en de clocenten van de Rijksuniversiteit Limburg. De keuze voor de neutrale positie in de facultaire organisatie werd eveneens belangrijk gevonden. Punten van kritiek waren de samenstelling van de begeleidingscommissie, die een groter multi-disciplinair karakter zou moeten hebben en de gecombineerde functie van de coördinator van het CEL, die tevens beheerder van de vakgroep huisartsgeneeskunde was.

In tegenstelling tot een aantal uitgangspunten van dit rapport heeft er in de jaren negentig een vrij natuurlijke samensmelting plaatsgevonden van het CEL en de vakgroep huisartsgeneeskunde. De redenen hiervoor waren tweeledig.

Enerzijds was de dubbelfunctie van de coördinator van het CEL, die tevens beheerder van de vakgroep was aanleiding om de beide takgebieden onder te brengen in de nieuwe sectie beheer en coördinatie van de vakgroep huisartsgeneeskunde.

Anderzijds was er de verantwoordelijkheidsverdeling tussen de vakgroep huisartsgeneeskunde en het CEL, onder andere tot uiting komend in de eerdergenoemde procedure. De vakgroep voelde zich in toenemende mate inhoudelijk verantwoordelijk voor alle onderzoek en onderwijs van en met huisartsen. Een zekere inhoudelijke toetsing door de vakgroep werd dan ook gaandeweg belangrijker. Het CEL bleef zijn verantwoordelijkheid in termen van organisatie, werving, financien en nazorg behouden.

Aangezien ook de andere vakgroepen in toenemende mate deze verantwoordelijkheden accepteerden, kon de organisatorische neutraliteit worden opgegeven, zodat de CEL-taak vanaf 1992 vorm kriggt vanuit de sectie beheer en coördinatie van de vakgroep huisartsgeneeskunde. De procedure heeft uiteraard geen verandering ondergaan. 
Helaas blijkt echter, met name ingegeven door tijdsproblematiek, dat het CEL zich in de latste twee jaren in termen van public relations niet sterk genoeg heeft geprofileerd. In 1995 zal derhalve opnieuw een uitgebreide informatienonde worden verzorgd, zowel in de richting van de huisartsen als naar de universitaire medewerkers.

Een andere belangrike constatering betreft de moeilijkheid om ook de industriele projecten met huisartsen te coördineren. Helas blijkt dat slechts zeer weinig industrieel onderzoekers bereid zijn de weg via het CEL naar de huisartsen te bewandelen. De industrie heeft dan ook andere (commerciële) belangen, eigen communicatie-kanalen met huisartsen en uitgebreidere financiële mogelijkheden om onderzoek met huisartsen te realiseren. De bereidheid om projecten zowel bij het CEL als bij de vakgroep huisartsgeneeskunde te melden en te toetsen is dan ook niet groot gebleken.

Slechts éên middel lijkt beschikbaar voor de oplossing van dit probleem en dit middel is in handen van de huisartsen zelf. Als de huisartsen, ondersteund door de Districts Huisartsvereniging, bereid zouden zijn om alle projecten die rechtstreeks bij de huisarts worden aangemeld door te verwijzen naar het CEL alvorens eventuele participatie te overwegen, kan ook de industrie deze procedure niet meer ontwijken. Optimalisering van de coördinatie van alle onderwijs en onderzoek met huisartsen zou het gevolg zijn van een dergelijke opstelling. Het CEL zou dan, ondersteund door de vakgroep huisartsgeneeskunde en de DHV een zogenaamd keumerk kunnen afgeven, waaruit de individuele huisarts kan opmaken dat een dergelijk project inhoudelijk en organisatorische beoordeeld en goed bevonden is. Vervolgens kan de huisarts zelf uiteraard altijd de afweging maken om wel of niet actief te participeren.

In de komende periode zal het accent van thet CEL dan ook komen te liggen op verdere dan wel hernieuwde bekendmaking met het type dienstverlening van dit bureau en zullen gesprekken met de DHV en individuelle huisartsen duidelijk moeten maken of coördinatie van alle (dus ook industrieel) onderzoek gewenst en mogelijk is.

Tevens wordt overwogen of gestratificeerde benadering van in bepaalde thematiek geinteresseerde huisartsen uitvoerbaar en wenselijk is. Een eerste studie hierover wordt in hoofdstuk 9 nader beschreven.

Ook een sudie naar het oordeel van huisartsen over deelname aan wetenschappelijk onderzoek, zoals gepresenteerd in hoofdstuk 8 biedt belangrijke aanknopingspunten voor de toekomstige uitwoering en coördinatie van met name wetenschappelijk onderzoek. 